Portland State University

PDXScholar

Spring 5-23-2014

\title{
Keeping Equity in Mind: Strategies for Continuing Equity Work Once Formal Training Has Ended
}

Teri Lynn Tilley

Portland State University

Follow this and additional works at: https://pdxscholar.library.pdx.edu/open_access_etds

Part of the Educational Methods Commons, and the Teacher Education and Professional Development Commons

Let us know how access to this document benefits you.

\section{Recommended Citation}

Tilley, Teri Lynn, "Keeping Equity in Mind: Strategies for Continuing Equity Work Once Formal Training Has Ended" (2014). Dissertations and Theses. Paper 1852.

https://doi.org/10.15760/etd.1851

This Dissertation is brought to you for free and open access. It has been accepted for inclusion in Dissertations and Theses by an authorized administrator of PDXScholar. Please contact us if we can make this document more accessible: pdxscholar@pdx.edu. 
Keeping Equity in Mind: Strategies for Continuing Equity Work

Once Formal Training Has Ended

by

Teri Lynn Tilley

A dissertation submitted in partial fulfillment of the requirements for the degree of

Doctor of Education

in

Educational Leadership: Administration

Dissertation Committee:

Tom Chenoweth, Chair

Amy Petti

Sally McWilliams

Dannelle Stevens

Portland State University

2014 
(C) 2014 Teri Lynn Tilley 


\begin{abstract}
Fifty years after Brown v. Board of Education, there remain large gaps in academic achievement between children of color and White students (Darling-Hammond, 2007). It is estimated that by 2050, the population of the United States will increase by $50 \%$; $90 \%$ of which will be accounted for by minorities (Vanneman, Hamilton, Anderson, \& Rahman, 2009). In less than 50 years, our citizenry will be comprised of "groups that are over represented among low achievers, and under represented among high achievers" (Ferguson, 2005, p. 4). Nationwide, districts are addressing the issue of the achievement gap through implementing formal equity professional development opportunities at their school sites. While formal equity training leaves participants transformed, they leave with little to no support in how to change their practice in order to teach more equitably. Therefore, based on Bridges' and Hallinger's (1995) problem based learning approach, the handbook, Keeping Equity in Mind, was developed, field tested and revised using Borg and Gall's (2003) research and development cycle. The purpose of this qualitative study was to determine the usefulness of the handbook, Keeping Equity in Mind, in supporting teacher leaders in continued equity work in their classrooms once formal equity training had ended at their school sites. Participants implemented the strategies presented in the handbook in order to determine its usefulness in supporting teacher leaders in continued equity work in their classrooms. The findings of this study determined Keeping Equity in Mind is a useful tool for teachers attempting to close the achievement gap in their classrooms and the administrators who support them.
\end{abstract}




\section{Dedication}

To my best friend, Alex, for encouraging me to continue my journey.

To my daughters, Clara and Charlotte, follow your dreams. 


\section{Acknowledgements}

I would not have been able to complete this work without the unwavering support from of my committee members, my family and friends, and my doctoral cohort. I would like to express my deepest gratitude to my advisor, Dr. Thomas Chenoweth, for his guidance, expertise, and encouragement throughout this process. I would like to thank him for challenging me to dig deeper and go beyond what I thought I was capable of doing. I would also like to thank Dr. Amy Petti, Dr. Dannelle Stevens, and Dr. Sally McWilliams for their support, without which, I would not have been able to complete this research.

I would like to acknowledge my cohort members, Dan Huld, Peter Siamoo, and Paul Coakley for their continued support and ability to make me laugh when I wanted to throw in the towel. In addition, I'd like to thank Carol Campbell, Dan Draper, and Linda Florence for their dedication to my success in this process. Finally, very special thanks goes to Brian Sien for helping me see this process through — we kept one another authentic and reminded one another to keep it simple - reminders, without which, we may have never gotten through this process.

I would also like to thank my mother, Leslie Tilley, for instilling in me the belief that I can achieve what I set out to do. I would also like to express my gratitude to Albert and Naomi Jasso who took it upon themselves to care for my daughters while I took the time necessary to complete this dissertation. Without them, this would not have been a possibility. 
Finally, I'd like to thank my husband, Alex Jasso. He was (and is) always there for me. He helped me see the light at the end of the tunnel. It is his belief in me that encourages me to continue to reach for my dreams. 
Table of Contents

Abstract

\section{CHAPTER I}

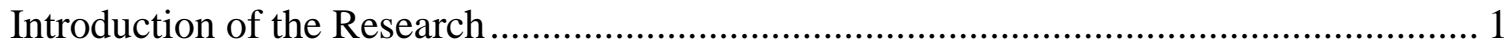

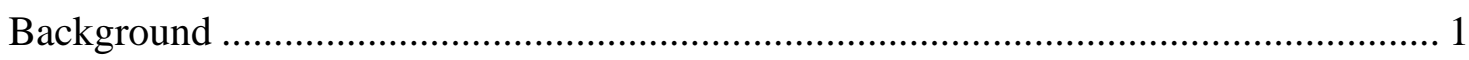

Identification of Problem ................................................................................ 2

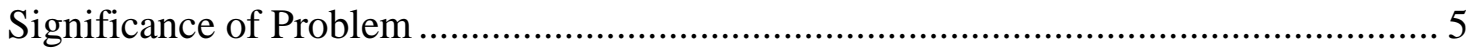

Why Focus Solely on Racial Equity? ............................................................ 7

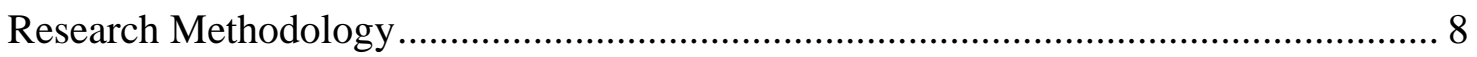

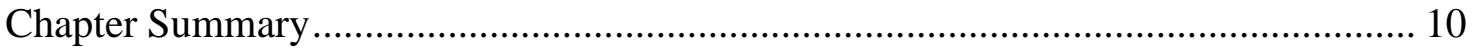

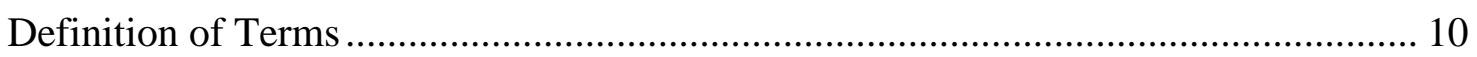

\section{CHAPTER II}

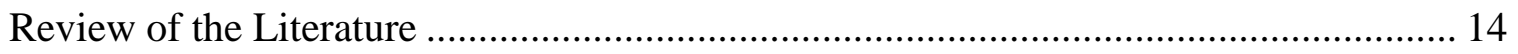

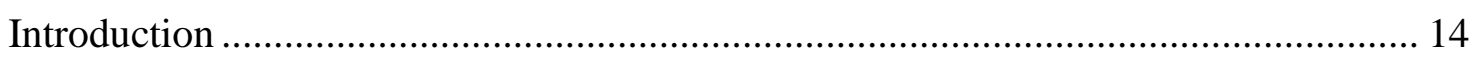

What Teachers Believe is Causing the Achievement Gap ......................................... 14

Professional Development Approaches........................................................... 16

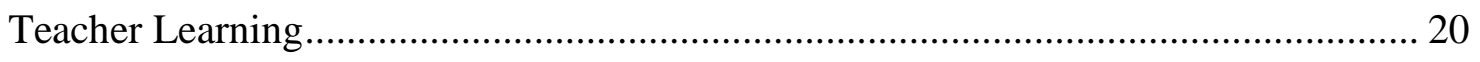

Why Professional Development Does Not Work ..................................................... 28

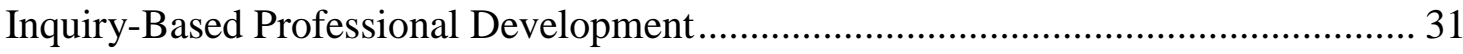

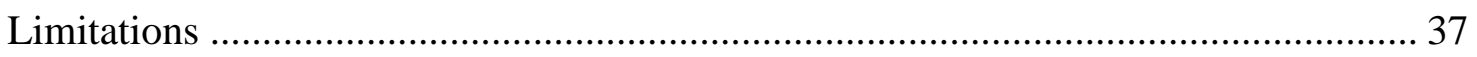

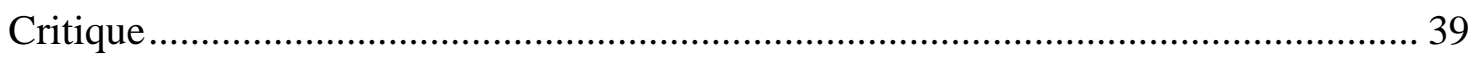

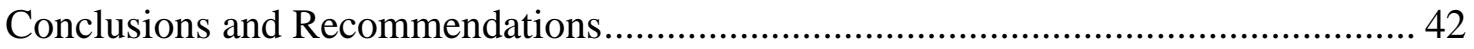


Chapter Summary

\section{CHAPTER III}

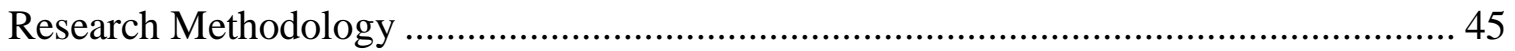

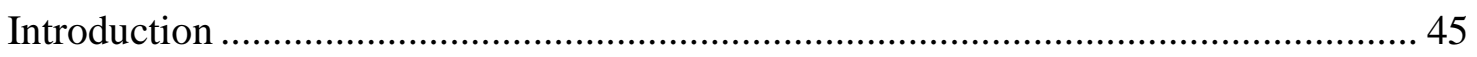

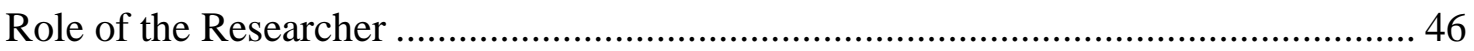

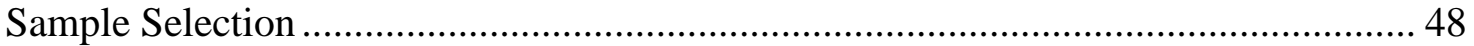

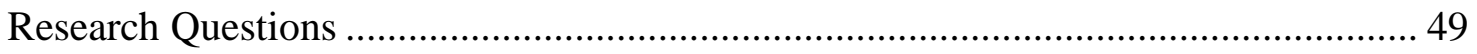

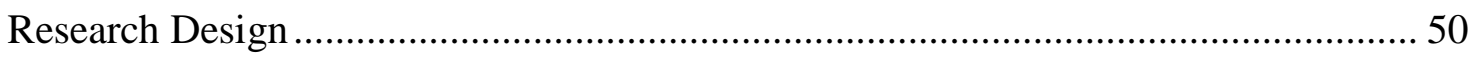

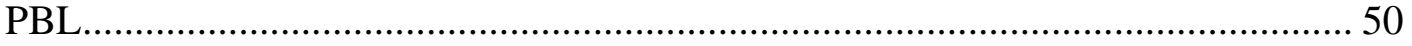

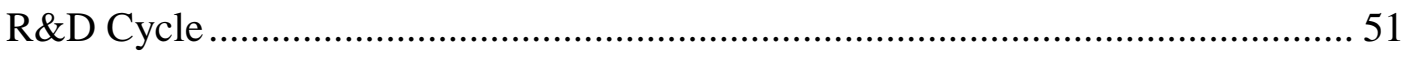

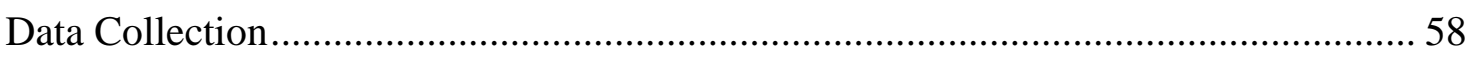

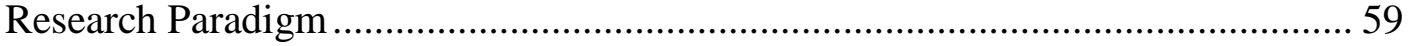

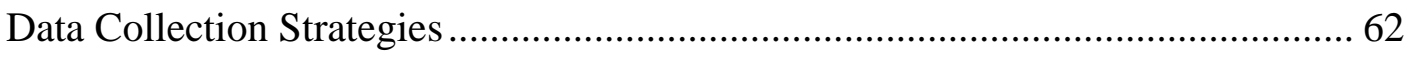

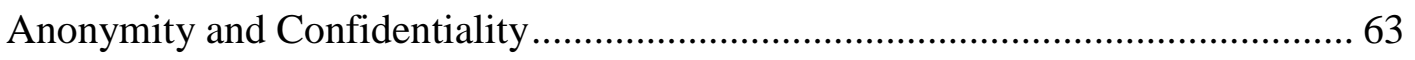

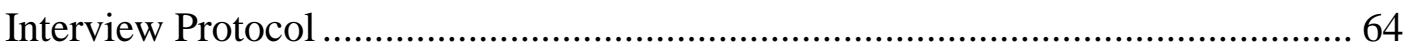

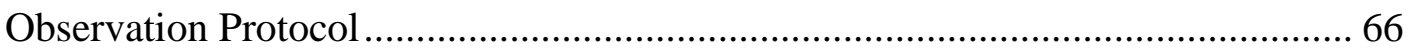

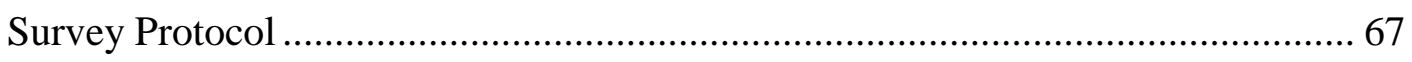

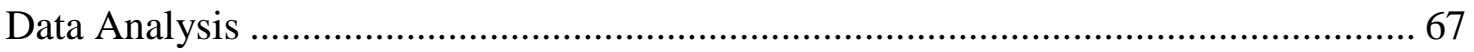

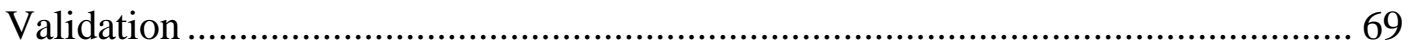

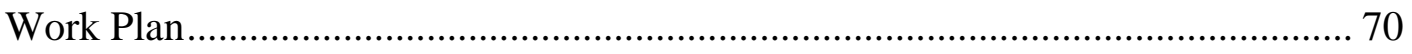

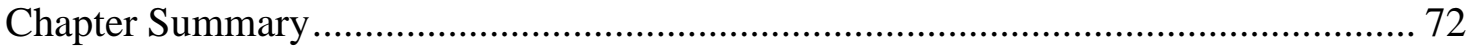

\section{CHAPTER IV}

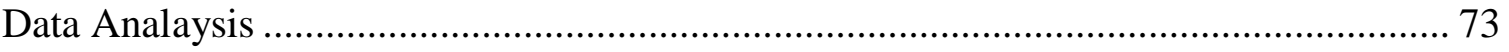

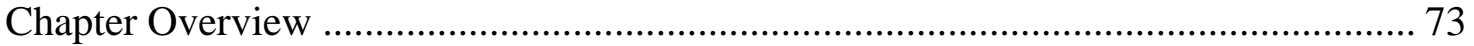

Review of the Research Questions and Goals ....................................................... 74

Review of the Research Questions ............................................................. 75

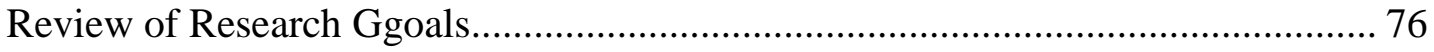

Development and Implementation of the PBL Project ........................................ 76 
Step 1: Research and Information Collecting .................................................... 76

Step 2: Planning Objectives, Learning Activities, and Small-Scale Testing ............ 83

Step 3: Develop Preliminary Form of the Product ............................................... 86

Steps 4 and 5: Preliminary Field Testing and Main Product Revisions ................... 88

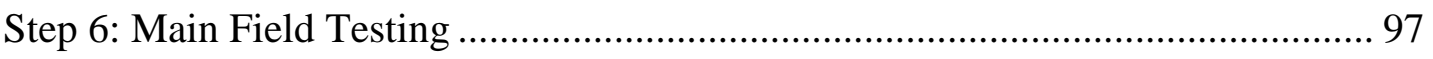

Step 7: Operational Product Revisions............................................................ 148

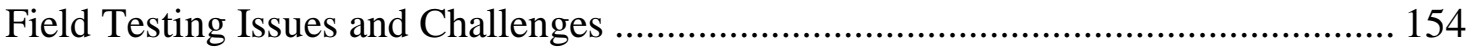

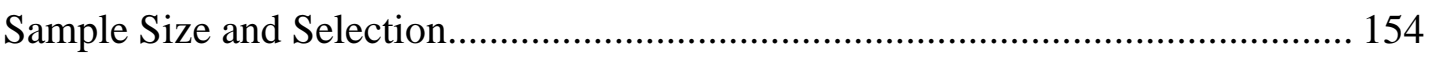

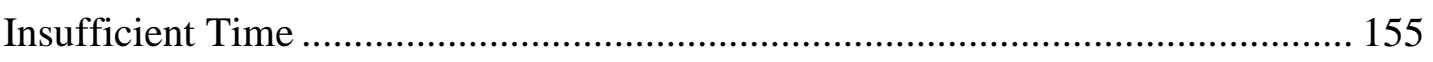

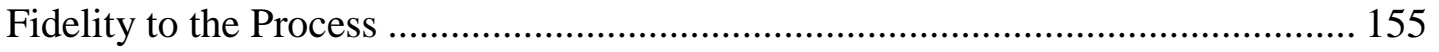

Would the Product Work at the Secondary Level? ............................................ 156

Collecting Student Assessment Data.............................................................. 157

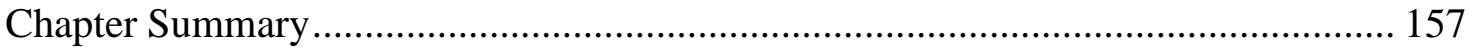

\section{CHAPTER V}

Conclusions, Speculations, and Recommendations for Leadership ............................ 159

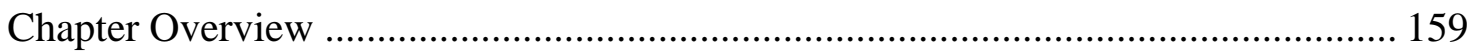

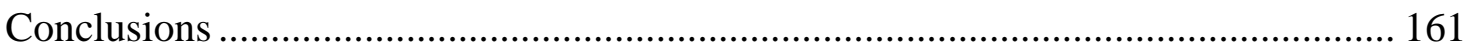

Steps 4 and 5: Preliminary Field Testing and Main Product Revision................... 161

Speculations for Future Research, Development, and Use of the Product ................. 164

Discussion and Speculations of Findings From an Adult Learning Perspective..... 164

Discussion and Speculations of Findings From a Reformative Professional

Development Perspective With a Focus on Inquiry ...................................... 167

Speculations for Future Research, Development, and Use of the Product.............. 169

Recommendations for Leadership .......................................................... 170

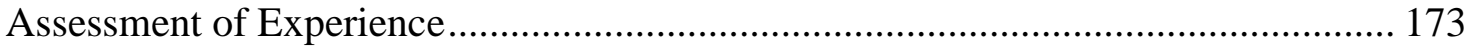

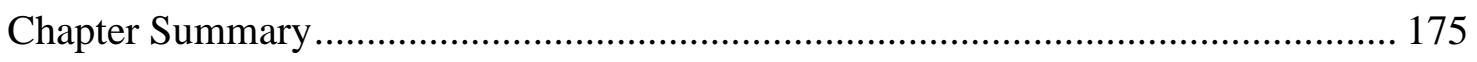

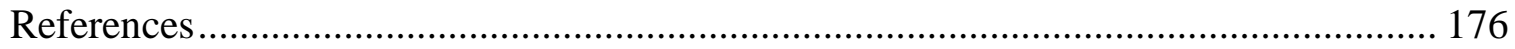




\section{Appendices}

A Participant Consent Form............................................................................... 182

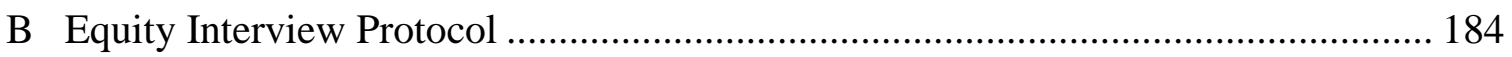

C Final Interview Protocol................................................................................... 188

D Planning Meeting Observation Protocol ............................................................... 193

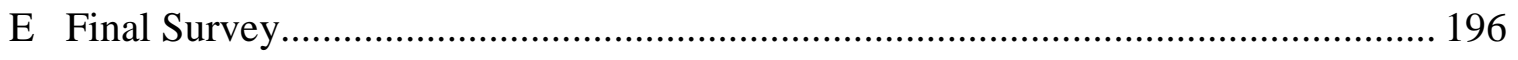

F Informational Meeting PowerPoint Presentation.................................................. 213

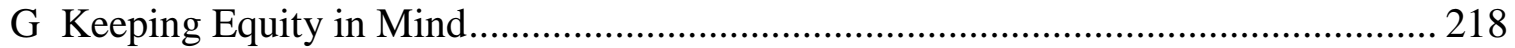


List of Tables

Table

1 Steps in the R\&D Cycle 9

2 Teacher Assumptions Regarding Student Achievement Based on Race and Economic Status. 15

3 Professional Development Approaches 18

4 How the Phases of Transformative Learning Relate to Professional

Development...

$5 \quad$ Traditional and Reform Professional Development ......................................... 29

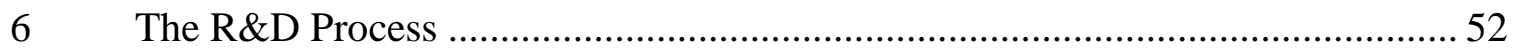

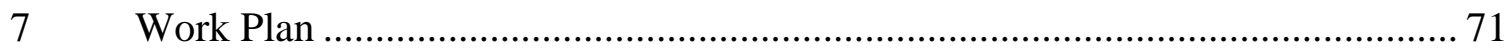

$8 \quad$ Primary and Secondary Research Questions ............................................. 75

9 Salient Questions for R\&D Product Determination....................................... 80

10 Outline of Preliminary Form of Product....................................................... 85

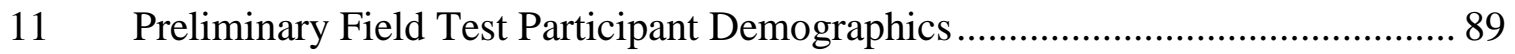

12 Preliminary Field Test Formative Codes, Data, and Actions Taken in Regard to Particular Sections of Keeping Equity in Mind............................................ 94

13 Preliminary Field Test Formative Codes, Data, and Actions Taken in Regard to Language Use and Possible Additions...................................................... 96

14 Main Field Test Data Collection Strategies .................................................... 98

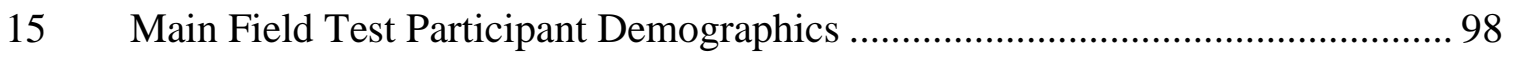

16 Transformation of Planning Meetings at Johnson Elementary ......................... 113

17 Pre- and Post-Assessment Data for Focal Students at Johnson Elementary....... 116

18 Teacher Perceived Self-Efficacy in Teaching Their Students of Color Prior To and After Implementing Keeping Equity in Mind 
19 Summary of Data Collection from Final Survey ........................................ 137

20 Participants' Likelihood to Continue Using Strategies Used in Keeping

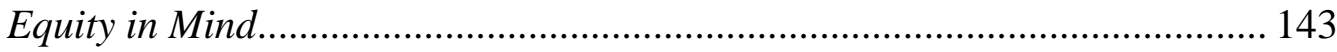

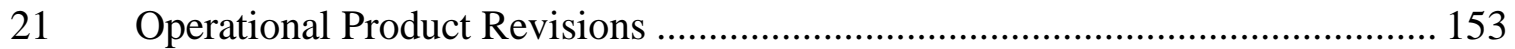

22 Transformational Phases Participants Went Through as a Result of Implementing Keeping Equity in Mind .................................................... 166 
List of Figures

Figure

Page

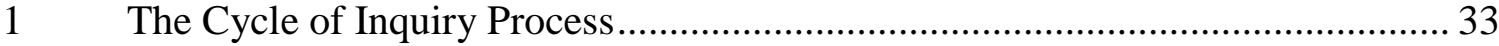


Preface

For the past nine years, I have been an educator in Title I schools in both California and Oregon, and I have had the opportunity to work with students from diverse cultural and socioeconomic backgrounds. I was fortunate enough to work at Cole Elementary (San Jose, California) where teachers and administrators actively strive toward closing the achievement gap between Black and Latino students and their Asian and White counterparts.

While Cole evolved to become a school dedicated to closing the achievement gap that was not always the case. In my first year of teaching at Cole, I blamed the circumstances with which my students were dealing for their lack of engagement or success at reaching benchmark. I often heard my colleagues (and I) say things such as, "His father is in jail, and his mother is a gang member. Of course he isn't doing well; he has too much to worry about at home." Another commonly used statement to legitimize poor student engagement and achievement was, "Both his parents are working two to three jobs, and he is taking care of his siblings and himself; no wonder he isn't doing his homework and he is falling asleep in class."

After using these excuses, I realized I was giving myself justification for not educating children based on extraneous circumstances. Of course it makes an educator's job easier if there is someone at home doing homework with a student, but it is not acceptable to say certain children will not learn because their circumstances are less than ideal. I could not believe that after one year, I had allowed several students to fall through the cracks. Imagine how many students had fallen through the cracks due to my 
colleagues who had been justifying the lack of student performance based on familial circumstances for the majority of their careers. Because of the educational gap between students of color and their White peers, and Cole's placement on Program Improvement, the administration decided it was time to dig deeper into the racial issues perpetuating the achievement gap at Cole, and this decision made all the difference.

When I first began teaching at Cole, the school was ranked 2 out of 10 against similar schools on the Annual Performance Index. Teachers began to ask the question, "What am I doing to ensure all my students are accessing state standards?" The focus shifted from, "Why aren't these kids learning what I am teaching them?" to "How can I deliver the material in a way that is culturally relevant to all of my students," thereby increasing engagement and learning? It was at this moment that things at Cole began to shift.

We came to the conclusion that the reason students were not meeting benchmark was because the system was not working for them. We realized we had biases that were keeping us from successfully educating our students of color. We were blaming our students (and their families) for their lack of success. It was no longer a question of how we teach this unit of study better, but of how we teach this unit of study so that all students can access to the information.

In questioning our own belief systems, we began to challenge our assumptions regarding the educational system and our students' capabilities, and we began to look at individual children in order to foster personal relationships, understand their backgrounds, and plan our curricular objectives to meet their needs. It did not take long 
to realize that the relationship between culture, curriculum, and practice would be the first step in beginning to close the achievement gap.

Through work with Partners in School Innovation and EdEquity, teachers at Cole began to have pedagogical and philosophical shifts regarding their instructional practices. By designing our curriculum to meet the needs of all of our students, and by ensuring we had equally rigorous standards for our students of color, we began to see immediate shifts in student achievement. When we began having these conversations in 2003 , only $13 \%$ of Cole's Latino students were reading at grade level. By 2006, 40\% of Latino students were reading at grade level, and Cole ranked 10 out of 10 against similar schools on the Annual Performance Index. In a few short years, we went from a school in the first stages of Program Improvement to a California Distinguished School.

My experience at Cole demonstrated that all children can learn if curriculum is thoughtfully addressed in ways that are culturally relevant and authentic to students' experiences. Unfortunately, however, I was disheartened to learn that once our administrator retired, and a new administrator was brought to Cole, Cole once again found itself underserving its students of color. In only two years under their new administrator, Cole was, again, scoring much lower than similar schools and not meeting Adequate Yearly Progress (AYP). Upon hearing this news, I realized teachers need support in continuing equity work - they the tool necessary to create an environment where they are capable of critically analyzing their practice and beliefs to meet student needs. It is crucial that conversations surrounding race and its link to student achievement begin to become part of teacher leaders' regular conversations regarding student success. 
I am hopeful Keeping Equity In Mind: A Tool for Teachers to Use While Planning Their Lessons in Order to Sustain Equity Work will be an effective tool educators can use in order to ensure they continue equity conversations and thoughtful planning for equitable instruction long after formal equity training has ended. 


\section{CHAPTER I}

\section{INTRODUCTION OF THE RESEARCH}

\section{Background}

The American education system faces a very daunting challenge: improving education for all students regardless of race, socioeconomic status, or gender. In a country that prides itself on the ideology of the American Dream and the ability of anyone to rise above poverty and marginalization through hard work and dedication in order to fulfill the dream of prosperity, it is becoming more and more apparent that achieving the American Dream is easier for some than for others. Often, people look toward education as the most direct avenue toward obtaining the American Dream (Ladson-Billings, 2009); however, a closer look at how education has been underserving children of color suggests the American Dream is obtainable for most members of the majority group, while it is kept just out of arm's reach for people of color. If education is the precursor to prosperity, then closing the achievement gap is imperative to ensuring all citizens have equal opportunity in pursuing the dream.

An achievement gap is a "content knowledge gap [that] exists between minority and non-minority children" (Sirota \& Bailey, 2009, p. 253). In 2007, the National Assessment of Education Progress (NAEP) reported that gaps between fourth grade Black and White math students existed in 46 of 50 states (Vanneman et al., 2009). Similarly, gaps between White and Black reading students existed in 44 states. While 
content knowledge gaps between these two races are decreasing, a national gap of 26 points in math and 31 points in reading still exist (Vanneman et al., 2009). If LadsonBillings (2009) is correct, in her assertion that education is a critical stepping stone in the pursuit of the American Dream, it is clear we reserve the dream for White students and deny it to many students of color.

\section{Identification of Problem}

This section, discusses the literature regarding why children of color are not learning as effectively as their White peers. This discussion begins by briefly reviewing the trends contributing to lowered achievement for students of color. Also discussed is how privilege and institutional inequalities undermine the attempts of educators to educate all children.

Several authors (Darling-Hammond, 2007; Delpit, 2006; Diamond, Randolph, \& Spillane, 2004; Gay, 2000; hooks, 1994; Howard, 2006; Ladson-Billings, 2009; McKenzie \& Scheurich, 2008; McLaren, 2007; Singleton \& Linton, 2006; Sirota \& Bailey, 2009; Tatum, 2003) identified teacher perceptions of students of color as one of the major attributors to America's achievement gap. Gay (2000) suggested five trends in teacher expectations deserve some attention. First, teacher beliefs regarding students' abilities to learn influence the type of instructional opportunities they give students. Teachers who have low expectations of their students teach with lowered rigor and commitment.

Second, teacher expectations regarding student achievement are often affected by factors that have no factual basis (Gay, 2000). For example, McKenzie and Scheurich 
(2008) conducted research in an urban elementary school where 80-90\% of the barriers reported by teachers in an effort to explain the achievement gap were external to the school (e.g., parents do not value education, the family is unable to support the child's learning at home, this student simply does not care about school, or this child is unable to learn because of their behavior). Similarly, Singleton and Linton (2006) claimed educators often blame the existing achievement gap on students' families, their culture or their community, or the students themselves.

A third trend is the assumption students of color cannot learn as well as White students (Gay, 2000). “As teachers' expectations for higher achievers increase, so does student performance, while the performance of low achievers becomes even worse when teachers have low expectations" (Gay, 2000, pp. 59-60). Another trend in teacher expectations is teachers tend to have higher expectations of their White students than they do for their students of color (with the exception of some Asian Americans) (DeCuir \& Dixson, 2004; Delpit, 2006; Howard, 2006).

Finally, teachers who have lowered expectations for underperforming students often do not feel efficacious about their competencies to teach those students (Gay, 2000). Diamond et al. (2004) studied the implications of teacher expectations of students of color and found that when "students' deficits were emphasized, teachers believed that students' lack of motivation, families, and limited skills undermined the teachers' ability to effectively teach" (p. 93). Because teachers believe certain students cannot learn, they, in turn, believe they are incapable of teaching them. 
Other contributors to the achievement gap are privilege and institutionalized inequalities that undermine the attempts of educators to teach all children (Adams, 2000; Adams, Bell, \& Griffin, 2007; Cochrane-Smith \& Lytle, 2001; Darling-Hammond, 2007; Delpit, 2006; Gay, 2000; Herr, 1999; hooks, 1994; Howard, 2006; Katz, 2003; LadsonBillings, 2009; McLaren, 2007; Nieto, 2002; Singleton \& Linton, 2006; Sirota \& Bailey, 2009; Tatum, 2003). Reforms of the past decades have traditionally focused on student deficits and the need for increased content knowledge and skill in delivering standardsbased instruction to begin to close the achievement gap (Borko, 2004; Darling-Hammond \& McLaughlin, 1995; Falk, 2001; Garet, Porter, Desimone, Birman, \& Yoon, 2001; Guskey, 2002; Hargreaves \& Dawe, 1990; McLaughlin \& Zarrow, 2001; Stokes, 2001); however, the belief that the educational institutions contributing to student failure deserve some attention (Howard, 2006; Little, 1993, 2001; McLaren, 2007).

Institutionalized racism includes the practices and institutional policies that perpetuate inequitable relationships between people of color and Whites (Katz, 2003; McIntosh, 1988). Derman-Sparks and Phillips (1997) identified practices in education that have inequitable outcomes, which include IQ testing, a lack of understanding about cultural learning styles, tracking, and Euro-centric curriculum. They argued these practices maintain the status-quo of institutionalized racism in schools. Furthermore, they pointed out "teachers who consider themselves nonracist because they do not hold overtly bigoted beliefs carry out these practices" (p. 11). For these reasons, among others, it is important to discuss institutionalized racism and its effects on widening the achievement gap. 
According to Singleton and Linton (2006), "educators cannot truly understand the challenges faced by students of color — challenges that result in lowered achievementuntil [they] develop a deeper understanding of what it means to be White" (p. 183). White privilege is a phenomenon that allows White people the opportunity of deciding when and where to address racial issues. Because of Whiteness, members of the dominant group are allowed to receive certain benefits associated with Whiteness, whether they are aware of their privilege or not (McIntosh, 1988).

White Privilege is "an invisible package of unearned assets which [one] can count on cashing in every day, but about which [one] was meant to remain oblivious" (McIntosh, 1988, p. 2). White privilege has become an elusive subject that comes with an immense pressure to ignore it, because if one chooses to recognize White privilege, they must in turn give up the myth of meritocracy and recognize the privilege and opportunities associated with Whiteness (McIntosh, 1988).

\section{Significance of Problem}

Because our nation has experienced and endured two centuries of slavery, a century of court-sanctioned segregation by race, and yet another half century of discrimination and differential access to education based on language, class, race, and background, it is becoming increasingly clear that our nation has become accustomed to educational inequalities that lead to lowered student achievement for children of color (Darling-Hammond, 2007). While we, as a nation, bemoan the inequitable educational outcomes between Black and Latino students and their White peers, we often "behave as though we are unaware of - or insensitive to - the equally substantial inequalities in 
access to educational opportunity that occur from preschool through elementary and secondary education, into college and beyond" (p. 318).

Fifty years after Brown v. Board of Education, there remain large gaps in academic achievement between children of color and White students (Darling-Hammond, 2007). Addressing the achievement gap in American is critical to ensuring our nation's prosperity. It is estimated that by 2050 , the population of the United States will increase by $50 \%$; $90 \%$ of which will be accounted for by minorities (Vanneman et al., 2009). In less than 50 years, our workforce will be comprised of "groups that are overrepresented among low achievers and underrepresented among high achievers" (Ferguson, 2005, p. 4). The social stability of our nation depends heavily on how dedicated we are to the pursuit of academic equity for students of color (Ferguson, 2005). Our nation cannot be successful in meeting the needs of the new economy if our students do not encounter more rigorous work in school, and many argue schools cannot improve unless the accomplishments (or the learning gaps) of their students become public knowledge (Darling-Hammond, 2007).

Furthermore, in order for a democracy to thrive in an atmosphere that requires a well- educated citizenry, it must create an educational system that can guarantee its students the right to learn. Many people of color do not receive the education they need in order to compete in a labor market that increasingly demands higher levels of education from its citizens. Nearly $70 \%$ of jobs in the United States today require specialized skills and training beyond high school (Darling-Hammond, 2007); if our students of color are 
not getting the same educational opportunities in our school systems, how can they compete in a job market as competitive as the one operating in the United States?

In order to address these inequities, educators must ask themselves: Why are our Black and Latino students not performing at the same level of proficiency as our White students? Silence among educators when it comes to discussing knowledge gaps between students of color only perpetuates the problem (Singleton \& Linton, 2006). As educators, we must begin to ask the tough question: How am I contributing to the widening of the achievement gap? By beginning to look at oneself introspectively, through inquiry-based transformative professional development activities, I believe educators can begin to transform their beliefs in a way that will lead to improved student achievement.

\section{Why Focus Solely on Racial Equity?}

As educators striving to achieve equity for all students, it is clear racial equity is only one piece of the puzzle. I strongly believe, as educators, we need to endeavor to teach in a manner that is rigorous enough to ensure girls achieve in math and science at the same level as their male counterparts, we need to fight for the equal representation of students in our LGBT communities - insuring they see themselves reflected in the materials we select, and we need to ensure we are reaching our students with special needs in a way that provides equitable access to a rigorous and authentic educational experience.

Educators struggle to meet the needs of all of their students every single day. Thankfully, school districts are starting to recognize teachers cannot win this battle alone - they need help. Districts across the nation are beginning to provide professional 
development opportunities to support their teachers in closing achievement gaps.

Middleton School District, the district where this study takes place, is dedicated to closing the racial achievement gap for their students of color. For this reason, this study is focused solely on supporting teachers in continuing equity work in their classrooms in order to begin to close the racial achievement gap for their students of color. This does not mean, however, educators can or will forget about other marginalized groups and stop striving to ensure equitable outcomes for them every single day they enter the classroom.

\section{Research Methodology}

For the purposes of addressing the need to support teachers in teaching for racial equity in their classrooms, I have designed this study grounded in problem based learning (PBL) (Bridges \& Hallinger, 1995). I have done so to "develop more productive linkages among research, theory, and practice" (p. 114) in order to address a real problem facing the educational system in America today: educating all students equitably. As a teacher in Title I schools in both California and Oregon, I have seen firsthand how students of color are not meeting standard as often as their White and Asian classmates. In addition, I have participated in several professional development opportunities designed to encourage teachers to teach with equity in mind; however, I have been disheartened to see educators struggle and become frustrated with equity work once formal equity training has ended, and thus, abandon the effort.

I decided to design this study using the research and development (R\&D) cycle in order to author and field test the handbook, Keeping Equity in Mind: A Tool for Teacher Leaders to Use While Planning Their Lessons in Order to Sustain Equity Work, which 
could potentially be one solution to the problem of continuing equity work once formal training has ended. In order to design a handbook that is useful for educational leaders dedicated to closing the achievement gap, this study progressed through the first seven steps of the R\&D cycle (Bridges \& Hallinger, 1995). Table 1 highlights the 10 -step R\&D cycle.

Table 1

Steps in the R\&D Cycle

\begin{tabular}{|c|l|}
\hline Step & \multicolumn{1}{|c|}{ Activity } \\
\hline 1 & Research and Information collecting \\
\hline 2 & Planning Objectives, Learning Activities, and Small-Scale Testing \\
\hline 3 & Develop Preliminary Form of the Product \\
\hline 4 & Preliminary Field Testing \\
\hline 5 & Main Product Revision \\
\hline 6 & Main Field Testing \\
\hline 7 & Operational Product Revision \\
\hline 8 & Operational Field Testing \\
\hline 9 & Final Product Revision \\
\hline 10 & Dissemination and Implementation \\
\hline
\end{tabular}

Source: Bridges and Hallinger (1995, p. 120)

For the purposes of this study, data sources included interviews, surveys, and observations as well as participant journals. The goal of this study was to determine if Keeping Equity in Mind is a useful handbook in supporting educators with the continuation of equity work in their classrooms. Chapter 3 discusses, in detail, the questions guiding this study, the research methodology employed, the data collection strategies and the data analysis techniques that were used for this study. 


\section{Chapter Summary}

This section discussed several possible reasons explaining why America's Black and Latino students are not achieving at the same level as their White and Asian peers. It presented five trends in teacher expectations that can be linked to lowered student achievement for students of color: (a) teachers' beliefs regarding students' abilities to learn influence the type of instructional opportunities they give students; (b) teacher expectations of student achievement is often based on factors that have no factual basis; (c) the assumption that students of color cannot learn as well as their White and Asian counterparts; (d) teachers tend to have higher expectations for their White students than they do for their students of color; and (e) teachers do not feel efficacious about teaching children of color, because they have lowered expectations for their academic abilities. This section also discussed practices such as institutionalized racism and privilege as contributors to lowered academic achievement for students of color.

Chapter 2 discusses the literature regarding the academic achievement gap for students of color. In addition, it discusses professional development opportunities presented educators in the $21^{\text {st }}$ century, and how these opportunities may not be enough to close the widening educational gap for students of color. Finally the next chapter discusses possible solutions to professional development opportunities that could lead to higher achievement for all students.

\section{Definition of Terms}

Achievement Gap: a "content knowledge gap [that] exists between minority and non-minority children" (Sirota \& Bailey, 2009, p. 253). 
American Dream: The idea that, in America, everyone can aspire to achieve an ideal life, including happiness and success, if they are willing to work hard enough.

Colorblind Lens: Educators teaching through a colorblind lens treat all students exactly the same - the race of their students does not affect their teaching practice.

Cycle of Inquiry: Teachers are given the opportunity to: (a) select and narrow a focus for inquiry into their own practice, (b) determine what goals they will set and measure, (c) create an action plan to work toward accomplishing those goals, (d) design a plan for implementing the desired action, and (e) collect and analyze data generated by their action (McLaughlin \& Zarrow, 2001).

Critical Theory: critical pedagogy/theory uses the metaphor of woven fabric to highlight the interconnectedness of the historical, political, and social aspects of education that must be examined in order to understand how schools function in ways that reproduce inequality. In addition, critical pedagogy provides an avenue through which educators may begin to understand the role schools play within a race divided society (McLaren, 2007).

Dominant Group: A group of people in a society that have power, privilege and social status.

Equity: Attempting to even the playing field for members of the minority group with those in the dominant group. Equity is not synonymous with equal. Equal means the same; equity implies that, in order to level the playing field, one must put more energy into closing the gap between the minority and dominant groups_-giving equal treatment may not be enough to achieve equity. 
Focal Students: Students "who are performing below grade level standard. Most often, focal students are representative of the larger achievement and opportunity gaps in [schools]" (Kidd \& Congdon, 2007).

Teacher Efficacy: The feeling educators have when they believe they have the capability to accomplish a goal.

Frame of Reference: "How one categorizes experiences, beliefs, people, events, and the self involves structures of assumptions and expectations on which our thoughts, feelings, and habits are based" (Mezirow \& Taylor, 2009, p. 22).

Inquiry as Stance: "The positions teachers and others who work together in inquiry communities take toward knowledge, its relationships to practice, and the purposes of schooling” (Cochrane-Smith \& Lytle, 2001, pp. 49-50).

Institutional Racism: Practices and institutional policies that perpetuate inequitable relationships between people of color and members of the dominant group (Katz, 2003; McIntosh, 1988).

Minority Group: Includes all groups that suffer from disparities of power or unequal treatment due to minority group membership.

Professional Development: Systemic efforts to bring about change in the classroom practices of teachers, in their attitudes, beliefs, and in the learning outcomes of students (Guskey, 2002).

Reflective Discourse: the act of looking critically at one's assumptions; it requires participants to have the courage and will to seek new understanding-to welcome differences and "try on" other points of view (Mezirow, 2000). 
Reform (Educational): The attempt to improve educational outcomes through changes in policy and practice.

Training Model of Professional Development: The most commonly used form of professional development designed as a "one-shot" transmission of information with little to no follow up (Borko, 2004; Little, 2001).

Transformative Learning:

Learning that transforms problematic frames of reference to make them more inclusive, discriminating, reflective, open, and emotionally able to change. Frames with these characteristics are more likely to generate beliefs and opinions that will prove more true or justified to guide action. (Mezirow \& Taylor, 2009, p. 22)

White Privilege: The phenomenon that allows White people the opportunity of deciding when and where to address racial issues. Because of Whiteness, members of the dominant group are allowed to receive certain benefits associated with Whiteness, whether they are aware of their privilege or not (McIntosh, 1988). 


\section{CHAPTER II}

\section{REVIEW OF THE LITERATURE}

\section{Introduction}

The relationship between student achievement and race has been considered in much of the literature I reviewed regarding the achievement gap between students of color and their White counterparts in the United States. This chapter discusses what the literature says regarding what teachers believe about the capabilities of their students of color and why they believe they are not achieving at the same standard as their White peers. Next, it discusses the purposes of professional development in an era of reform and adult learning theory, transformative learning in particular, and how the use of critical theory in educational professional development opportunities can promote transformative learning. It then discusses the approaches to professional development the literature suggests are the least and the most effective in affecting teacher change, and why those that are ineffective do not work. In addition, this chapter discusses why, in order to facilitate transformative learning, professional development should be based in inquiry. Finally, this chapter concludes with a discussion of the limitations of the research I reviewed and the implications of those limitations for future research.

\section{What Teachers Believe is Causing the Achievement Gap}

Of the literature I reviewed, several authors (Diamond et al., 2004; Gay, 2000; McKenzie \& Scheurich, 2008; Singleton \& Linton, 2006) identified teacher perceptions of students of color as one of the major attributors to America's achievement gap. In a 
study performed by Diamond, et al. (2004), teachers of five urban schools were asked to describe the capabilities of the children they teach; their expectations for White and Asian students were very different from those for their Black students (regardless of socioeconomic status). Table 2 summarizes the discrepancies between teachers' assumptions of Black students' abilities and those of their White or Asian peers as reported by Diamond et al. (2004).

Table 2

Teacher Assumptions Regarding Student Achievement Based on Race and Economic Status

\begin{tabular}{|c|c|c|c|}
\hline School & $\begin{array}{l}\text { Race of } \\
\text { Students }\end{array}$ & Socioeconomic Status & Comments Made by Teachers About Students \\
\hline $\begin{array}{l}\text { Lewis } \\
\text { School }\end{array}$ & $\begin{array}{l}\text { Majority } \\
\text { White }\end{array}$ & $64 \%$ Low Income & $\begin{array}{l}\text { "eager to learn" } \\
\text { "highly motivated" } \\
\text { "mature" }\end{array}$ \\
\hline $\begin{array}{l}\text { Harris } \\
\text { School }\end{array}$ & Majority Asian & $84 \%$ Low Income & $\begin{array}{l}\text { "catch on quickly" } \\
\text { "excellent math" }\end{array}$ \\
\hline $\begin{array}{l}\text { Davis } \\
\text { School }\end{array}$ & $100 \%$ Black & $60 \%$ Low Income & $\begin{array}{l}\text { "generally good kids" } \\
\text { "good kids compared to other schools" } \\
\text { "lack respect for adults" }\end{array}$ \\
\hline $\begin{array}{l}\text { Erikson } \\
\text { School }\end{array}$ & $100 \%$ Black & 90\% Low Income & $\begin{array}{l}\text { "too social" } \\
\text { "lack discipline" } \\
\text { "disrespectful" }\end{array}$ \\
\hline $\begin{array}{l}\text { Adams } \\
\text { School }\end{array}$ & Majority Black & Unavailable & $\begin{array}{l}\text { "no one in their family has an education" } \\
\text { "influenced by drugs, crime, and [other issues } \\
\text { in] the inner city" }\end{array}$ \\
\hline
\end{tabular}

Source: Diamond et al. (2004)

In their study, Diamond, et al. (2004) recognized a pattern between lowered teacher expectations and lowered achievement of Black students compared to Asian and White students. They found, of the teachers working in schools with a predominantly 
White or Asian student population, $71 \%$ emphasized student assets when asked to discuss student capabilities. On the other hand, of the teachers working in schools with a predominately Black student population, only $23 \%$ emphasized student assets when asked to share their beliefs regarding student achievement. If we hope to close the achievement gap, I believe it is imperative to offer teachers professional development activities that support inquiry and challenge taken-for-granted beliefs about students of color in order to transform the manner in which educators teach and think about students not belonging to the majority group. In the following sections, I discuss the purposes of professional development in an era of reform and adult learning theory, transformative learning in particular, and how it relates to teacher learning and professional development.

\section{Professional Development Approaches}

In an era of accountability, high quality professional development is an aspect of nearly every reform effort (Falk, 2001; Garet et al., 2001; Guskey, 1986, 2002; Lambert, 2002; Little, 2001). "Policymakers and public leaders show an increasing tendency to portray teachers' work as the work of reform—and more specifically, the reform of classroom teaching in ways that result in more uniformly high levels of student achievement" (Little, 2001, p. 41). In order to enter into reform efforts focusing on closing the achievement gap through high quality professional development, it is important to understand what the literature says regarding professional development and its link to change. 
Professional development programs are "systemic efforts to bring about change in the classroom practices of teachers, in their attitudes and beliefs, and in the learning outcomes of students" (Guskey, 2002, p. 381). For several decades, research has shown the least effective, yet most commonly used, model of professional development is the workshop approach, or the training model, which is often a one-day activity designed to transmit knowledge to teachers with little to no follow up (Borko, 2004; Desimone, Porter, Garet, Yoon, \& Birman, 2002; Falk, 2001; Garet et al., 2001; Guskey, 2002; Little, 1993; Stokes, 2001). When asked on a national survey the type of professional development they participate in most, $81.3 \%$ of teachers surveyed responded they were participating in professional development activities that would fall into the category of the training model (Desimone et al., 2002). For this reason, it is important to understand the various approaches to professional development and how they support or negate efforts to close the achievement gap.

In the literature I reviewed, professional development activities can be categorized into three approaches: (a) knowledge-for-practice, (b) knowledge-in-practice, and (c) knowledge-of-practice (Cochrane-Smith \& Lytle, 2001). Implicit in professional development activities designed as knowledge-for-practice is a metaphor of teacher as "technician" rather than teacher as "professional" or "intellectual" (Hargreaves \& Dawe, 1990). This type of professional development activity is designed to address curricular and instructional change (Little, 2001) and many times involves the participation of specialists in order to facilitate the transmission of knowledge from expert to technician, or teacher (Cochrane-Smith \& Lytle, 2001; Falk, 2001; Little, 2001). Knowledge-for- 
practice activities are typically characterized by short-term or one-shot workshops or lectures (Falk, 2001), which research shows do not affect school-wide change or student achievement (Borko, 2004; Desimone et al., 2002; Garet et al., 2001; Stokes, 2001).

Table 3

Professional Development Approaches

\begin{tabular}{|c|c|c|c|}
\hline $\begin{array}{l}\text { Type of Professional } \\
\text { Development }\end{array}$ & $\begin{array}{c}\text { Professional Development } \\
\text { Activities }\end{array}$ & Location of Knowledge & $\begin{array}{l}\text { Duration of } \\
\text { Activity }\end{array}$ \\
\hline $\begin{array}{l}\text { Knowledge-for- } \\
\text { practice }\end{array}$ & $\begin{array}{l}\text { - Workshops } \\
\text { - Institutes } \\
\text { - College Courses } \\
\text { - Conferences }\end{array}$ & $\begin{array}{l}\text { Within the expert } \\
\text { facilitating the professional } \\
\text { development activity- } \\
\text { knowledge is deposited in, } \\
\text { or given to, participants }\end{array}$ & $\begin{array}{l}\text { Range from } 1-5 \\
\text { days }\end{array}$ \\
\hline $\begin{array}{l}\text { Knowledge-in- } \\
\text { practice }\end{array}$ & $\begin{array}{l}\text { - Observing expert } \\
\text { teachers in the field } \\
\text { - Probe expert teachers }\end{array}$ & $\begin{array}{l}\text { With the expert teacher- } \\
\text { knowledge is deposited in, } \\
\text { or given to, participants }\end{array}$ & $\begin{array}{l}\text { Can range from } \\
\text { one observation to } \\
\text { several }\end{array}$ \\
\hline $\begin{array}{l}\text { Knowledge-of- } \\
\text { practice }\end{array}$ & $\begin{array}{l}\text { - Study Groups } \\
\text { - Mentoring } \\
\text { - Coaching } \\
\text { - Teacher Collaboratives }\end{array}$ & $\begin{array}{l}\text { Within the educator- } \\
\text { knowledge is generated } \\
\text { through problematizing } \\
\text { beliefs and practice }\end{array}$ & $\begin{array}{l}\text { Ongoing } \\
\text { throughout } \\
\text { career — cyclical; } \\
\text { becomes a process } \\
\text { of practice }\end{array}$ \\
\hline
\end{tabular}

Source: Garet et al. (2001)

Professional development activities structured within a knowledge-in-practice approach are designed under the assumption that the most essential knowledge for teaching is practical knowledge - that is, teachers learn best when they are able to probe the knowledge of expert teachers or given the opportunity to strengthen their own knowledge through designing "rich learning interactions in the classroom" (CochraneSmith \& Lytle, 2001, p. 47). While it is possible educators may learn something from the aforementioned types of professional development activities, it is clear that transformation of beliefs will not occur due to the lack of critical reflection on one's own 
practice. I believe professional development activities that fall within the knowledge-ofpractice approach are most successful in affecting change in teachers' belief systems about the capabilities of students of color, and, therefore, lead to transformation.

When educators are engaged in knowledge-of-practice, they are participating in professional development activities that encourage inquiry (Cochrane-Smith \& Lytle, 2001). With the current challenges facing reform efforts (ensuring all students have equitable outcomes), I believe professional development opportunities that explicitly incorporate elements of inquiry will be more successful in closing the achievement gap because educators will be given the opportunity to critically examine their practice and how it affects student achievement, positively or negatively, and will lead to the transformation of beliefs. McLaughlin and Zarrow (2001) argued that in schools where educators are engaged in inquiry,

problems [are] transformed from 'social facts' to subjects for inquiry and problem solving. This transformation [is] most apparent... where explanations for poor student performance [move] from those based on beliefs about students' attitudes, backgrounds, or capacities to the 'fit' between what students [need] to learn and achieve and what [is] provided them. (p. 93)

I worry that professional development opportunities that fall within the approaches of knowledge-for-practice and knowledge-in-practice will not lead to transformed beliefs about students of color, and therefore, teachers will not reconstruct their taken-for-granted beliefs. Therefore, in order to offer teachers professional development opportunities that could potentially lead to the transformation of their takenfor-granted beliefs, professional development, I believe, should be designed using a knowledge-of-practice approach that fosters critical reflection and discourse. In the next 
section, I discuss constructivist adult learning theory, transformative learning in particular, and how it lends itself to supporting professional development activities designed from within a knowledge-of-practice approach.

\section{Teacher Learning}

In her article On Two Metaphors for Learning and the Dangers of Choosing Just One, Sfard (1998) discussed the use of metaphor in analyzing and determining the assumptions underpinning specific learning perspectives. In her work, she identified two metaphors that can be used in order to better understand learning and how it relates to professional development activities. Learning perspectives focusing primarily on the acquisition of knowledge or the attainment of content (e.g., knowledge-for-practice and knowledge-in-practice) can be understood in terms of an acquisition metaphor. On the other hand, if the focus shifts from accumulating knowledge to understanding learning as a process through which one becomes a member of a community, learning can be conceptualized in terms of a participation metaphor (knowledge-of-practice). Sfard discussed the importance of operating between both the acquisition and participation metaphors for learning in order to ensure the dictatorship of one metaphor does not "lead to theories that serve the interests of certain groups to the disadvantage of others" (p. 11).

Sfard (1998) highlighted the importance of recognizing the relationship between acquisition and participation metaphors in transferring previously attained knowledge to participation in new communities that lead to transformed beliefs about students of color. Educators must first be able to analyze the knowledge they have accumulated regarding the capabilities of students of color (Delpit, 2006; Gay, 2000; Howard, 2006; Singleton \& 
Linton, 2006), how the acquisition of this knowledge occurred (e.g., through participating in the privileges awarded members of the dominant culture or adhering to societal explanations for lowered student achievement for students of color), and the knowledge itself must be analyzed in order to transform assumptions into discussions leading to discourse. Reflective discourse is the act of looking critically at one's assumptions; it requires participants to have the courage and will to seek new understanding - to welcome difference and "try on" other points of view (Mezirow, 2000). Through discourse, educators begin to recognize their taken-for-granted frames of reference regarding student achievement. Without acknowledging acquired biases in their takenfor-granted frames of reference, educators will not be able to participate in reconstructing knowledge regarding students of color.

Both the acquisition and participation metaphors are implied in Singleton and Linton's (2006) framework for Courageous Conversations. Their framework includes recognition of acquired knowledge in order to communicate and understand how knowledge has contributed to lowered student achievement for Black and Latino students. Their framework is dependent on the interconnectedness of both the acquisition and participation metaphors. While their framework provides learning opportunities for educators to join a community of practice where educators are able to participate in reconstructing their assumptions regarding students of color, this discourse could not occur without the acknowledgement and transfer of their previously acquired beliefs regarding Black and Latino students. 
Through acknowledging the acquired frames of reference teachers hold in regard to students of color and achievement, educators can begin to participate in a community of learners dedicated to ensuring knowledge does not continue to strengthen those already in power, but instead, begins to liberate those who have been oppressed (Sfard, 1998). In many ways, professional development opportunities residing between the acquisition and participation metaphors for learning allow educators to analyze their previously acquired assumptions in order to participate in the "process of becoming a member of a certain community. This entails, above all, the ability to communicate in the language of this community and act according to its particular norms" (Sfard, 1998, p. 6). The community to which educators must strive to belong is the community of those who recognize differences, have difficult discussions around student achievement and race, and determine interventions that are likely to affect student achievement. Like all communities, this community of educators must have its own language and its own set of norms through which educators can discuss student achievement and plan interventions for students not meeting standard. As a result of becoming a member of this new community, transformative learning takes place, and teachers will look at the work they do in a completely different way (Borko, 2004; Desimone et al., 2002; Falk, 2001; Garet et al., 2001; Guskey, 1986; Little, 1993; Stokes, 2001).

Some of the literature suggests, in order to close the achievement gap, professional development should: (a) allow teachers to become more knowledgeable about the subjects they teach, and (b) focus on implementation of standards (Borko, 2004; Haycock, 1998). Implicit in this discussion of professional development is an 
acquisition metaphor as well as a knowledge-for-practice approach; it refers to teachers acquiring deeper understanding of the content they teach, so they can help students attain mastery of state standards. I assume most (if not all) educators would agree the more knowledgeable a teacher is, the more effectively they will educate students; however, if a teacher has lowered expectations for students of color, they will teach the students with lowered rigor regardless of their level of expertise (Diamond et al., 2004).

It is important to raise the notion that perhaps a paradigm that resides solely in the camp of an acquisition metaphor contributes to the perpetuation of the status-quo, and makes it, in my opinion, close to impossible to transform our current educational practices that serve to raise the status of the dominant group. If knowledge is viewed as property to be owned, then it becomes the means by which the powerful cement their position in society while it serves to bind the powerless to continued oppression (Sfard, 1998). If educators are to transform the way they perceive or "know" students of color, professional development must not resort to mere acquisition of knowledge. Professional development must provide opportunities to acquire information in order for teachers to have an opportunity to participate in the unveiling of their beliefs contributing to the widening of the achievement gap.

Another way to examine adult learning theories pertinent to transformational professional development is to analyze the ontological and epistemological assumptions in the literature. The literature I reviewed regarding professional development which encourages educators to analyze their assumptions in order to reconstruct new points of view regarding the achievement of students of color is consistent with constructivist 
learning. The metaphor representing constructivist theory is carpentry or construction work (Ernest, 1994). This metaphor describes understanding as building or constructing mental structures. Within this metaphor is an opportunity for learners to transform, or change conceptually, their previously built mental structures. Further, social constructivism argues that the realm of the social and the individual are interconnected; therefore, the metaphor for the mind is persons in conversation (Ernest, 1994). Social constructivist theory relates to transformational professional development designed within a knowledge-for-practice approach because the focus of concern "is not just with the teacher's knowledge of subject matter and diagnostic skills, but with teacher's beliefs, conceptions and personal theories about subject matter, teaching, and learning" (p. 12). While the metaphor of carpentry represents constructivist theory, critical pedagogy uses the metaphor of woven fabric to highlight the interconnectedness of the historical, political, and social aspects of education that must be examined in order to understand how schools function in ways that reproduce inequality (McLaren, 2007). In order to understand teaching children of color, educators must acknowledge that institutions, teacher assumptions, and structures of conventional education are European American enterprises and, as such, are ethno-centric (Gay, 2000; Howard, 2006). Including a critical perspective of learning in educational professional development opportunities will allow teachers to analyze privilege and its effects on learning.

Furthermore, Little (1993) asserted that in order to begin to close the achievement gap, educators must resist the urge to do what they have done historically and begin to look with a critical lens toward institutional structures that have attributed to lowered 
student achievement for students of color. Little argued professional development must encourage educators to ask questions, pose problems, and explore curiosities in a way that changes their perspectives, their policies, and their practices. I believe professional development activities designed to be transformational and inquiry based could be an effective manner in which educators can begin to do the things Little has considered imperative to teaching children of color. Critical pedagogy provides an avenue through which educators may begin to understand the role schools (and they) play within a race divided society (McLaren, 2007).

In order to help educators recognize how the roles of history, society, and politics have contributed to the achievement gap, critical pedagogists argue teachers must be provided the opportunity to analyze educational institutions as places that reflect the ideologies of the dominant group (McLaren, 2007). In the same vein, Singleton and Linton (2006), Gay (2000), McKenzie and Scheurich (2004), and Diamond et al. (2004) have argued if educators are going to close the achievement gap, they must begin by understanding the roles institutionalized racism and teacher bias play in contributing to the widening of the gap. In order to begin to understand this, I believe they need opportunities to engage in inquiry about their practice and their beliefs in order to transform the way in which they teach their students of color.

Through looking at education through a critical theorist's lens, educators can begin to transform their beliefs about students of color. According to Mezirow (2000), transformative learning involves the participation of teachers as learners in discourse that examines the experiences of others in order to analyze how learners have justified their 
assumptions regarding other groups. Through assessing one's assumptions, learners can make decisions based on new insights. Transformation Theory provides a basis on which educators can begin to examine their taken-for-granted frames of reference. Mezirow argued learning is a process of understanding and interpreting prior knowledge in order to transform one's interpretation of experiences into a new frame of reference that is more inclusive, reflective, and capable of change.

Mezirow and Taylor (2009) described a process through which adults go in order to reach a transformation of beliefs. They described a 10-step transformative process that I argue is missing from the professional development frameworks I have reviewed. The process by which transformation is achieved, and how I believe it relates to transformative learning for teachers is presented in Table 4.

Singleton's and Linton's (2006) model for professional development begins the transformative process, but it falls short of the final steps, which I believe are the most important to closing the achievement gap. In Courageous Conversations, teachers are supported through the first four steps of transformative learning: (a) recognizing a disorienting problem, (b) examining self, (d) assessing one's beliefs, and (e) recognizing that in order to relieve the discomfort caused by the disorienting problem, one must transform their taken-for-granted frames of reference. Singleton and Linton dabbled with the fifth component of transformative learning (exploration of new roles and relationships); however, their model for professional development falls short in an essential component of transformative learning: planning for and implementing future action, which leads to new perspectives for teachers. 
Table 4

How the Phases of Transformative Learning Relate to Professional Development

\begin{tabular}{|c|c|c|}
\hline & $\begin{array}{l}\text { Mezirow's Phase of } \\
\text { Transformative Learning }\end{array}$ & $\begin{array}{l}\text { How Mezirow's Phase of Transformative Learning Relates } \\
\text { to Professional Development/ Learning for Educators }\end{array}$ \\
\hline 1 & $\begin{array}{l}\text { Learners are faced with a } \\
\text { disorienting dilemma. }\end{array}$ & $\begin{array}{l}\text { Teachers realize they have lowered academic expectations } \\
\text { for their students of color. }\end{array}$ \\
\hline 2 & $\begin{array}{l}\text { Learners are encouraged to } \\
\text { participate in self-examination in } \\
\text { order to recognize taken-for- } \\
\text { granted frames of reference. }\end{array}$ & $\begin{array}{l}\text { Teachers ask themselves, Why do I have lowered } \\
\text { expectations for my students of color? }\end{array}$ \\
\hline 3 & $\begin{array}{l}\text { Learners engage in an assessment } \\
\text { of their taken-for-granted frames } \\
\text { of reference. }\end{array}$ & $\begin{array}{l}\text { Teachers begin the dialogue of whether or not their } \\
\text { assumptions are accurate or a result of White privilege. }\end{array}$ \\
\hline 4 & $\begin{array}{l}\text { Learners recognize that their } \\
\text { discontent is a result of the } \\
\text { process of transformation. }\end{array}$ & $\begin{array}{l}\text { Teachers are resilient and persevere through the discomfort } \\
\text { of analyzing biases. }\end{array}$ \\
\hline 5 & $\begin{array}{l}\text { Learners begin to recognize and } \\
\text { explore new roles, relationships, } \\
\text { and actions. }\end{array}$ & $\begin{array}{l}\text { Teachers begin to ask themselves what they can do } \\
\text { differently in their practice to meet the needs of all students. }\end{array}$ \\
\hline 6 & $\begin{array}{l}\text { Learners put a plan of action in } \\
\text { place. }\end{array}$ & $\begin{array}{l}\text { Teachers plan to become more aware of societal norms and } \\
\text { White privilege to begin to plan future action. }\end{array}$ \\
\hline 7 & $\begin{array}{l}\text { Learners acquire new knowledge } \\
\text { and strategies in order to } \\
\text { implement their new plan of } \\
\text { action. }\end{array}$ & $\begin{array}{l}\text { Teachers make plans to begin to study their previous taken- } \\
\text { for-granted frames of reference in order to determine how } \\
\text { they can change their practice to promote higher } \\
\text { achievement for students of color. }\end{array}$ \\
\hline 8 & $\begin{array}{l}\text { Learners implement their new } \\
\text { plan of action. }\end{array}$ & $\begin{array}{l}\text { Teachers take their new learning from phases } 6 \text { and } 7 \text { into } \\
\text { their classroom and implement new strategies to meet the } \\
\text { needs of Black and Latino students. }\end{array}$ \\
\hline 9 & $\begin{array}{l}\text { Learners become more competent } \\
\text { and confident in their new role. }\end{array}$ & $\begin{array}{l}\text { Teachers begin to feel as though they have the power to } \\
\text { facilitate closing the achievement gap. They begin to see } \\
\text { themselves as change agents in equity teaching. }\end{array}$ \\
\hline 10 & $\begin{array}{l}\text { Learners' new frame of reference } \\
\text { is integrated into their } \\
\text { perspective. }\end{array}$ & $\begin{array}{l}\text { Teachers no longer teach in a manner that is colorblind; they } \\
\text { teach students differently based on their needs, and they } \\
\text { believe that all students can be successful. }\end{array}$ \\
\hline
\end{tabular}

Source: Mezirow (1997)

I is my assumption teachers leave Courageous Conversations changed; they may

recognize they have been part of an educational system that is inherently racist against

Black and Latino students, and perhaps they leave with transformed frames of reference 
regarding the achievement capabilities of their students of color. However, Courageous Conversations does not appear to support the creation of a plan for future action; therefore, teachers' transformations end before their new frames of reference are integrated into their perspective and practice. I believe allowing educators the opportunity to engage in inquiry-based professional development can allow them to move into planning and implementing future action, thus integrating their new frames of reference into their practice.

In order to close the achievement gap, I believe professional development needs to support transformative learning and provide educators an opportunity to create a community of learners that critically reflects on their practice in order to transform their taken for granted beliefs regarding students of color. In the following section, I discuss what the literature says regarding the types of professional development activities most often offered teachers and why it is unsuccessful in transforming teachers' beliefs, and, therefore, failing to close the achievement gap. I also discuss why using transformative learning theory to design professional development activities steeped in inquiry may be the best tactic to ensure all students have equitable outcomes.

\section{Why Professional Development Does Not Work}

In their national study, Garet et al. (2001) described two types of professional development, traditional and reform, as well as the activities associated with each (see Table 5). Professional development activities that fall into the category of traditional, or knowledge-for-practice, are least likely to affect change in teachers' practice or beliefs (Borko, 2004; Cochrane-Smith \& Lytle, 2001; Darling-Hammond \& McLaughlin, 1995; 
Falk, 2001; Garet et al., 2001; Guskey, 2002; Little, 1993, 2001; Stokes, 2001). However, teachers participating in reform activities, or professional development activities described as knowledge-of-practice, report having transformed beliefs about achievement and how their practice influences it (Darling-Hammond \& McLaughlin, 1995; Garet et al., 2001; McLaughlin \& Zarrow, 2001).

Table 5

Traditional and Reform Professional Development

\begin{tabular}{|c|l|l|l|}
\hline $\begin{array}{c}\text { Type of Professional } \\
\text { Development }\end{array}$ & \multicolumn{1}{|c|}{$\begin{array}{c}\text { Professional } \\
\text { Development Activities }\end{array}$} & Location of Knowledge & Duration of Activity \\
\hline $\begin{array}{c}\text { Traditional } \\
\text { (Knowledge-for- } \\
\text { Practice) }\end{array}$ & $\begin{array}{l}\text { - Workshops } \\
\text { - Institutes } \\
\text { - College Courses } \\
\text { - Conferences }\end{array}$ & $\begin{array}{l}\text { With the expert facilitating } \\
\text { the professional } \\
\text { development activity }\end{array}$ & Range from 1-5 days \\
\hline $\begin{array}{c}\text { Reform } \\
\text { (Knowledge-of- } \\
\text { Practice) }\end{array}$ & $\begin{array}{l}\text { - Study Groups } \\
\text { - Mentoring } \\
\text { - Coaching }\end{array}$ & $\begin{array}{l}\text { Within the educator- } \\
\text { knowledge is generated } \\
\text { through problematizing } \\
\text { beliefs and practice }\end{array}$ & $\begin{array}{l}\text { Ongoing throughout } \\
\text { career-cyclical; } \\
\text { becomes a process of } \\
\text { practice }\end{array}$ \\
\hline
\end{tabular}

Source: Garet et al. (2001)

While the literature suggests reform type professional development activities are most effective in affecting change (Darling-Hammond \& McLaughlin, 1995; Garet et al., 2001; McLaughlin \& Zarrow, 2001), 79\% of the 1,027 teachers surveyed reported the professional development activities they participated in most commonly were of the traditional type (Garet et al., 2001). I believe this is one of the reasons the achievement gap continues to exist. If we do not change the way in which we think about teacher learning, I fear we will see continued discrepancies in the achievement of students of 
color and their White peers. For this reason, I think activities that support inquiry leading to transformed beliefs is what is missing from traditional models of professional development.

Darling-Hammond and McLaughlin (1995) argued the success of the reform agenda depends on "teachers' success in accomplishing the serious and difficult task of learning the skills and perspectives assumed by new visions of practice and unlearning the practices and beliefs about students and instruction that have dominated their professional lives" (p. 597). In order to unlearn previously held beliefs, teachers need to be supported in the transformative learning process. I believe professional development activities which are inquiry based are the best strategies to facilitate transformative learning.

According to the literature, there are several characteristics of high-quality professional development - most of which would be included in professional development activities supporting inquiry-based transformative learning. Professional development should encourage teachers to engage in critical discourse regarding their practice and reflect on student achievement in a manner which is data driven (CochraneSmith \& Lytle, 2001; Darling-Hammond \& McLaughlin, 1995; Little, 2001; McLaughlin \& Zarrow, 2001). In addition, professional development activities that have been considered transformative include opportunities for teachers to observe one another and reflect critically on their own.

Professional development of this kind ... creates new images of what, when, and how teachers learn, and these new images require a corresponding shift from work of teachers to strategies intended to develop schools' and teachers' capacity 
to be responsible for student learning. (Darling-Hammond \& McLaughlin, 1995, p. 598)

In order to develop teachers' capacity to be responsible for student learning, it is necessary to have a framework for professional development which supports teachers engaging in inquiry to transform their beliefs and guide their instruction. The next section discusses inquiry-based professional development activities, the cycle of inquiry in particular, and why I believe it lends itself well to transformative learning theory and critical pedagogy. In addition, I argue this type of professional development activity might be more successful in closing the achievement gap than the commonly used traditional models.

\section{Inquiry-Based Professional Development}

A growing body of literature supports the notion of inquiry-based professional development as the approach most likely to facilitate transformative learning (CochraneSmith \& Lytle, 2001; Darling-Hammond \& McLaughlin, 1995; Desimone et al., 2002; Elmore, 1996; Garet et al., 2001; Lambert, 2002; Little, 1982, 1993, 2001; McLaughlin \& Zarrow, 2001; Stokes, 2001). In this section, I discuss inquiry-based professional development with an emphasis on the cycle of inquiry (McLaughlin \& Zarrow, 2001) and how research shows inquiry leads to the transformation of teacher beliefs and increased student achievement. I then argue that any reform agenda aimed at closing the achievement gap should be grounded in an "inquiry stance" on teaching that is both critical and transformative (Cochrane-Smith \& Lytle, 2001).

Cochrane-Smith and Lytle (2001) described inquiry as stance as "the positions teachers and others who work together in inquiry communities take toward knowledge, 
its relationships to practice, and the purposes of schooling" (pp. 49-50). The metaphor of stance is used to describe how educators define the ways in which they see, and the lenses through which they examine the social, political, historical, and cultural significance of schooling.

Fundamental to this notion is the idea that the work of inquiry communities is both social and political - that is, it involves making problematic the current arrangements of schooling; the ways knowledge is constructed, evaluated, and used; and teachers' individual and collective roles in bringing about change. (p. 50)

Inquiry as stance allows educators to look critically at their practice (and the results of their practices) in order to determine how they can transform their current practices to meet the needs of all students. This process, I believe, is essential when educators take on the challenge of closing the achievement gap.

A framework I feel lends itself well to supporting teachers through the process of taking on a stance of inquiry is the cycle of inquiry (McLaughlin \& Zarrow, 2001). In a cycle of inquiry (see Figure 1), as in Cochrane-Smith and Lytle's (2001) inquiry as stance, teachers are given the opportunity to: (a) select and narrow a focus for inquiry into their own practice, (b) determine what goals they will set and measure, (c) create an action plan to work toward accomplishing those goals, (d) design a plan for implementing the desired action, and (e) collect and analyze data generated by their action (McLaughlin \& Zarrow, 2001). The cycle of inquiry works through many of the components of transformative learning, and therefore, is appropriate for educators attempting to transform their beliefs regarding their students of color. As a participant in a cycle of inquiry, teachers are given the opportunity to see first-hand whether or not their practice 
is impacting the achievement of their students, particularly their students of color. If teachers are reflecting critically on their own practice and whether or not if affects student learning, I believe they are likely to begin to look at systems of inequity, which may be their own practice, as the cause for lowered student achievement rather than continue to blame the students themselves.

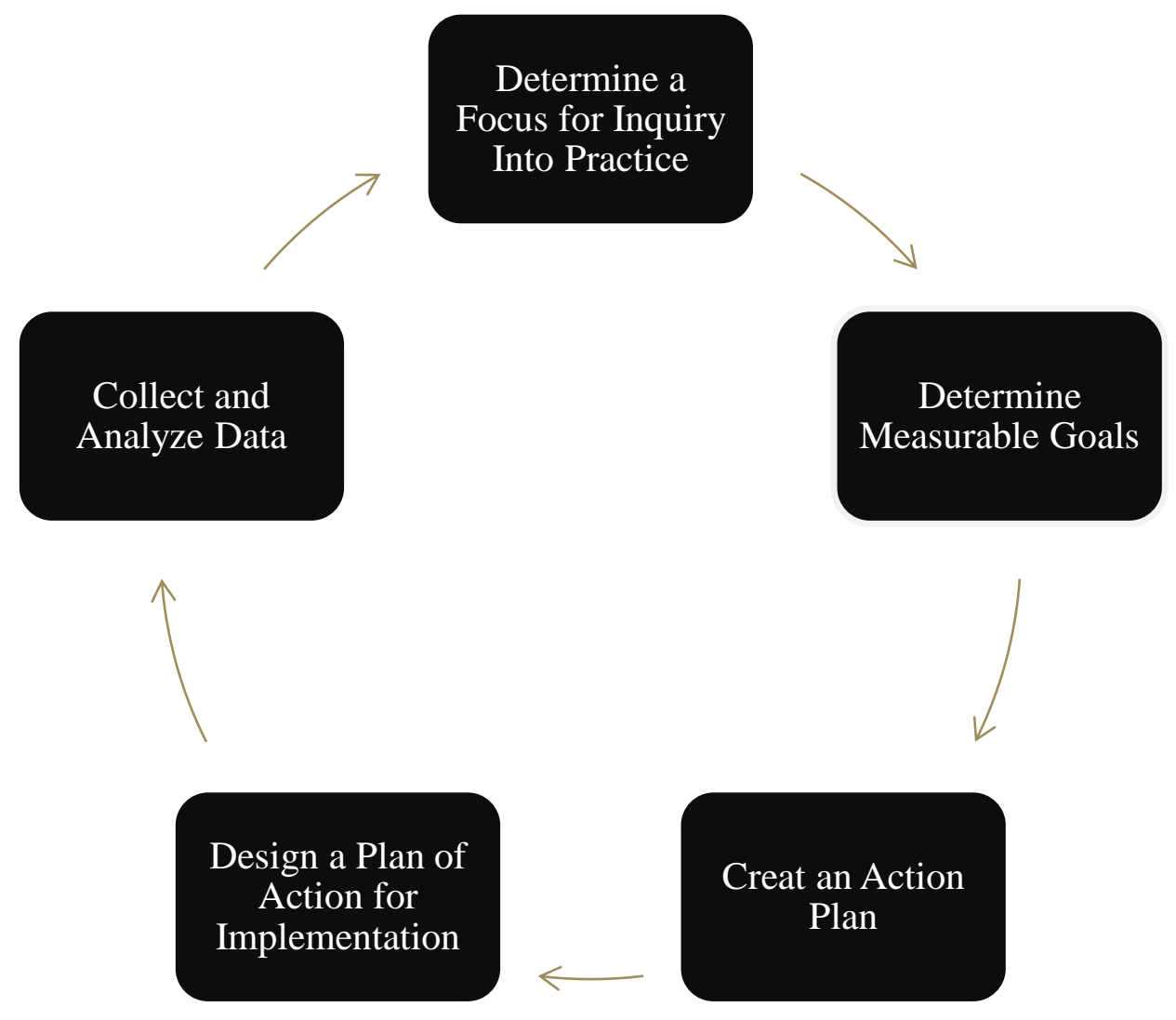

Figure 1. The Cycle of Inquiry process. This is a process through which educators can design an inquiry into practice in order to create an action plan for instruction, collect and analyze data, and plan follow-up actions. Adapted from McLaughlin and Zarrow (2001).

McLaughlin and Zarrow (2001) discussed their involvement in studying one of the largest school reform efforts in California, The Bay Area School Reform Collaborative (BASRC). BASRC was a 5-year reform effort in the San Francisco Bay 
Area which studied schools, throughout the 118-district region, engaging in a cycle of inquiry in order to attempt to close the achievement gap. BASRC's aim was to "change the way schools do business" (p. 79).

By engaging in a cycle of inquiry, teachers in BASRC schools began to see growth in students' achievement. In addition, they began to identify concrete gaps in students' learning. "What had been generic problems became more concrete- they took on names and faces" (McLaughlin \& Zarrow, 2001, p. 88). Because teachers in BASRC schools were coached to identify students who were not meeting standard and determine what obstacles stood in the way of those students meeting standard, they were able to problematize the obstacles standing in the way of their students and make a focused action plan for removing those obstacles.

Between the years of 1988 and 1989, BASRC schools improved student achievement in $77 \%$ of participating elementary schools, $64 \%$ of participating middle schools, and 59\% of participating high schools (McLaughlin \& Zarrow, 2001). If, in one year, BASRC schools can change the way teachers do their work resulting in significant gains, one could argue they were on track to beginning to close the achievement gap in participating schools.

Building upon the work done in BASRC schools, Partners in School Innovation (San Francisco, CA) implemented a Results Oriented Cycle of Inquiry (ROCI) in order to focus intently on data in order to allow it to drive inquiry and instruction (Kidd \& Starr, 2011). ROCI is a five-step process

designed to support individuals in sharpening their focus on results and developing habits that fuel continuous improvement. ROCI focuses everyone's 
attention directly on student learning; stimulates people to learn from their successes and to implement their provisional solutions and monitor how they are working. In this way, ROCI engages teachers and other leaders at every level as true learning leaders and, simultaneously, as leaders of sustained organizational learning and improvement. (p. 5)

Through a Results Oriented Cycle of Inquiry, Partners in School Innovation has shown success in the schools with which they work. In 2010, the 12 schools partnered with Partners in School Innovation showed a gain of 6.1 percentage points on the California Standards Test in English Language Arts, a gain of more than three times the state as a whole made (Kidd \& Starr, 2011). In addition, 33\% of participating schools achieved double-digit increases in literacy gains and "outpaced the state in literacy gains made by African-American, Latino, and English Learner students" (p. 8).

One aspect of Partners in School Innovation's Results Oriented Cycle of Inquiry I find interesting is their incorporation of focal students. Focal students are students are students "who are performing below grade level standard. Most often, focal students are representative of the larger achievement and opportunity gaps in the school" (Kidd \& Congdon, 2007, p. 1). Teachers working with Partners in School Innovation are encouraged to choose five focal students who are below standard, but within reach of meeting grade level goals. Teachers observe these students, interview these students, and plan their cycles of inquiry with these students in mind. The idea is if teachers are designing their lessons to meet the needs of their focal students (and measuring the results), they will teach in a more rigorous fashion, and a ripple effect will occur. Because they focus intently on the learning of their five focal students, the rest of their students will also benefit from this planning (Kidd \& Congdon, 2007). 
Hunt, Soto, Maier, and Doering (2003) saw similar success when they used focal students to implement instruction to better meet the needs of Special Education students as well as General Education students at risk of not meeting benchmark. Teachers collaborated with support staff to implement Unified Plans of Support (UPS) for focal students in order to specifically target students with lowered success rates in their schools. Prior to implementation, the rate of engagement for focal students was significantly lower than their classmates. Following implementation, focal students' rate of non-engagement decreased from an average of $33 \%$ to a range of $0.2 \%$ to $5 \%$. In addition, focal students began to interact with their teachers and their peers $18 \%$ to $29 \%$ more often than before implementation. Through targeted instruction designed to meet the needs of their focal students, teachers observed (a) an increase in engagement from focal students, (b) an increase in efficacy shown by focal students, (c) an increase in interactions between focal students and their peers, (d) an increase in focal students asking for help, and (e) an increase in enjoyment of classroom activities (Hunt et al., 2003).

Through inquiry, schools are beginning to see a narrowing of the achievement gap that is quite encouraging. In order to maintain the momentum created by BASRC and Partners in School Innovation, I believe it is imperative we begin to look closely at inquiry and how it can transform teachers' beliefs regarding the capabilities of their students of color. In addition, by giving teacher leaders the opportunity to begin to see "inquiry as a stance" (Cochrane-Smith \& Lytle, 2001), we are giving them the 
opportunity to change patterns of institutionalized inequities that have been present in our schools for decades.

The literature shows a growing body of research suggesting teachers participating in professional development activities should be treated as active learners rather than recipients of knowledge. Gone are the days of designing professional development activities that are one-shot remedies with little to now follow up. In an era of reform, teachers must be supported in engaging in critical pedagogy in order to undo the inequities compounded by so many years of systemic racism in our schools. It is necessary to design professional development activities that encourage teachers to analyze data, reflect on their practice in relation to the data, propose possible solutions, and design actions to test if their solution is successful. In doing so, educators will be participating in the critical discourse Mezirow and Taylor (2009) argued is essential to transformation of taken-for-granted frames of reference. In addition, the cycle of inquiry process will allow educators to participate in professional development steeped in critical pedagogy in order to begin to understand how educational inequities for students of color impact their achievement.

\section{Limitations}

My primary purpose in reviewing the literature was to identify the implications of professional development on closing the achievement gap. While I was able to find substantial information on the achievement gap and possible explanations for its existence, most of the literature I came across dealt specifically with the traditional belief that teacher knowledge and successful implementation of standards-based curriculum is 
the leading factor in closing the achievement gap. I found very limited data analyzing the results of professional development opportunities that transformed teachers' beliefs about students of color and whether or not these types of professional development opportunities lead to increased achievement. The only data I was able to find to support the success of transformative professional development in closing the achievement gap was that done by Singleton and Linton (2006). Because they are reporting on a framework they designed to transform teachers' beliefs about students of color, their bias cannot be overlooked.

From my review, it appears that more research needs to be conducted in measuring the effects of transformative learning on closing the achievement gap. Other areas to continue exploring are: (a) studies focusing on the implications of institutionalized racism in school settings, and how addressing them lead to a measured increase in student achievement; (b) discussions on how transformed beliefs about the capabilities of students of color can be measured and correlated to achievement; and (c) how can professional development be structured and monitored in order to facilitate transformation?

It is clear from the literature I reviewed that the achievement gap between students of color and their White counterparts is of particular interest in educational research. While I was able to uncover several reports proving the existence of the gap and research explaining why the gap may exist, the waters were shallow when it came to professional development that leads to transformational learning for teachers resulting in a lessening of the gap between students of color and the dominant group. Nevertheless, 
the relationship between professional development transforming teachers' beliefs about the academic abilities of students of color and closing the achievement gap are waters worth exploring.

\section{Critique}

I am hopeful that all children in our country can learn if given the appropriate opportunities. It is because of this belief I have decided to dedicate my work as an educator to exploring the causes of the achievement gap in order to understand how educational leaders can organize professional development opportunities for teachers that lead to increased achievement for all students. Because I believe teacher expectations and biases are two of the primary reasons for the achievement gap, I was particularly interested in analyzing literature that discussed the types of professional development that have been successful in transforming teachers' beliefs regarding children of color. I was eager to find examples of transformational learning and critical theory perspectives and their effects on student achievement. In this section, I will critique the strengths and limitations of the literature I reviewed in terms of assumptions, metaphor, approaches to inquiry, power relations, and matters of equity.

The majority of the literature I reviewed states that teachers' biases and assumptions regarding the achievement capabilities of students of color is a fundamental cause attributing to the achievement gap (Diamond et al., 2004; Gay, 2000; McKenzie \& Scheurich, 2008; McLaren, 2007; Singleton \& Linton, 2006). An underlying assumption in the majority of the literature I reviewed is the belief that recognizing institutional structures that lead to lowered student achievement for Black and Latino students is 
enough to change teachers' perspectives about students of color. This assumption (as I mentioned in my analysis above) does not allow for the implementation of a new plan of action which leads to new frames of reference being integrated into teachers' perspective (Mezirow \& Taylor, 2009). If teachers' perspectives are not modified to include new frames of reference, I worry that teachers will continue to work with Black and Latino children in the same manner they have traditionally.

The use of metaphor is limited in the literature I reviewed. While the participation and acquisition metaphors are implied in professional development opportunities that are transformational, the implicit nature of their presence is noteworthy. It seems that participation metaphor as well as Bateson's (1994) learning as coming home fits well with critical theory in that "teachers are unaware of their own un-verbalized knowledge and take it for granted as a foundation, failing repeatedly in the attempt to teach pupils from other backgrounds in whom that knowledge is absent or different" (p. 207). Through critical analysis of power, educators can begin to see learning as a homecoming for children of color rather than a process that alienates them.

In the limitations section of the literature review, I stated that I was unable to find analyses of professional development that transformed teachers' beliefs regarding students of color and whether or not these types of professional development are leading to increased student achievement. Singleton and Linton (2006) were the only authors I reviewed that attempted to measure student success based on transformation of teacher beliefs. While the data they provide shows increased student achievement for Latino and Black students, it does not give mention to teacher beliefs and how they changed (though 
it is implied). If transforming teachers' beliefs regarding their students of color is a key component in closing the achievement gap, more research needs be done in order to gather data measuring the change in teachers' perceptions of students of color (or lack thereof) and the relationship between transformed teachers' beliefs and improved student achievement.

Power relations and matters of equity are critical to my analysis of transformational professional development, because I believe it is our moral obligation to ensure all children have equitable opportunities to learn. It is important that educators begin to look not only at what schooling means but also at how schooling has come to mean what it does (McLaren, 2007). McLaren (2007) argued that schools are not what we have traditionally believed—socializing agencies that educate intelligent, skilled citizens - but rather they are institutions where the ideologies of the dominant group are reinforced contributing to social issues such as racism, sexism, and classism. Educators must make the "distinction between schooling and education. The former is primarily a mode of social control; the latter has the potential to transform society" (pp. 191-192). If educators are going to have the skills and courage to teach students in a critical manner, they must first experience their own transformation. In order to ensure equitable teaching is happening in our schools, we must recognize the role of racism (both institutional and personal) in maintaining positions of power for White Americans.

Further, Mezirow (2000) purported there are inequities in social structure that influence the way in which one understands their own experience. "Learners need to become critically aware of how these factors have shaped the ways they think and their 
beliefs so they may take collective action to ameliorate them" (p. 28). Through liberating oneself from "reified forms of thought" (p. 29), educators can begin to transform their way of thinking and acting by beginning to empower others in the surrounding community to stop blaming students for their lowered academic achievement and begin to look critically at the institutions that have served to oppress students of color. In doing so, educators can take the first steps in creating a more socially just world.

\section{Conclusions and Recommendations}

My purpose in analyzing literature about professional development and its role in closing the achievement gap has been to get a better understanding of what some of the literature says about the role racism plays in underachievement for students of color in our country. In reviewing the literature I gathered, it has become clear that the achievement gap between students of color and White students is of particular interest in educational research. The review of literature showed various options for designing professional development opportunities which lead to increased student achievement. While some of the studies (Barth et al., 1999; Haycock, 1998) focus on the positive effects increased content knowledge of teachers has on student achievement, I cannot help but wonder how focusing on standards alone will address the inherent racism in our educational systems.

Therefore, I must join the many scholars (Darling-Hammond, 2007; Delpit, 2006; Gay, 2000; hooks, 1994; Howard, 2006; Ladson-Billings, 2009; McLaren, 2007; Nieto, 2002; Sleeter, 2001; Tatum, 2003) who are beginning to look at the miseducation of Black and Latino students through a pedagogical lens that is both critical and 
transformative. I believe that in order to address societal issues of race and class that are perpetuated in the education of our citizens, more research needs to be done on the effects of teacher perceptions of students of color. While I understand quantifying one's beliefs and biases is an undertaking that is complex at best-it is an avenue of research that can begin to evoke social change that empowers educators to do what they originally set out to do-educate intelligent, dedicated, and skilled citizens regardless of race.

Often, change can be paralyzing, and transformation, though paramount in closing the achievement gap, is something that educators need to be supported through; otherwise, educators who are resistant to the process may participate in the discourse but continue to teach with closed doors. In order to work toward a more just society, educators must be willing to look critically at those in power and those who are oppressed. Through beginning to dissect the intricacies of racial stratification in our society, we can begin to unravel the fabric that history, politics, and society have woven together in order to bind the relationship between race and privilege.

\section{Chapter Summary}

This chapter highlighted the literature on the most likely reasons children of color, particularly Black and Latino students, are not performing with the same academic success as their White and Asian classmates. This chapter also discussed the professional development opportunities participated in by teachers most frequently and how these opportunities do not lead to transformation of teacher beliefs or practice. In addition, this chapter reviewed the literature that suggests professional development that is inquiry based is most likely to support educators in closing the achievement gap. 
The following chapter introduces readers to the research design of this dissertation work and discusses the questions that guided the study. It also highlights the research methodology, data collection methods, and data analysis tools used in this study. It describes how the handbook was field tested using the R\&D cycle (Borg \& Gall, 2003), and how the study was designed to gather data on the effectiveness of Keeping Equity in Mind in order to revise it to meet the needs of educators dedicated to closing the academic gap for their students of color. My hope is, through the R\&D process, this handbook will become a valuable tool educators can use to begin to undo the inequities our students of color face as they enter into the American educational system. 


\section{CHAPTER III \\ RESEARCH METHODOLOGY \\ Introduction}

As I have mentioned in previous chapters, it is up to educators to begin to ask the tough questions: What am I doing to contribute to the achievement gap, and What can I do to ensure all students in my classroom are given equitable educational opportunities? In order to successfully begin to challenge the status quo, I believe educators and educational leaders need support. It is my hope that Keeping Equity in Mind will offer one type of support to educators dedicated to beginning to challenge and close the academic gap between their White students and their students of color.

Keeping Equity in Mind is a hands-on resource designed for teacher leaders dedicated to continuing equity work and the administrators who support them. It walks readers through the steps necessary in determining focal students — students of color who are below grade level — and designing engaging lessons through a cycle of inquiry process in order to motivate and inspire them. The handbook supports readers in determining focal students, designing lessons with a specific standard in mind, designing common formative and summative assessments, using the data to drive instruction, and building and maintaining strong relationships with focal students.

In this section, I discuss the role of the researcher and sample selection. In addition, I introduce the research questions that guided this study. I explain why I chose to design this study using PBL employing the R\&D cycle as the methodology (Borg \& 
Gall, 2003), and how this process lends itself well to educational research. I also describe the R\&D process and briefly describe what I did at each stage of the development process (for a more in-depth discussion of each step of the R\&D process, see chapter 4). In addition, I discuss the data collection strategies I employed in this research as well as how I analyzed said data. Finally, I end this chapter with a timeline of the data collection process.

\section{Role of the Researcher}

This study took place at two school sites in Middleton School District: Johnson Elementary and Sunset High School. The role of the researcher was that of participant-asobserver (Borg \& Gall, 2003; Johnson \& Christensen, 2008). “The participant-asobserver spends a good deal of time in the field participating and observing" (Johnson \& Christensen, 2008, p. 214). I was able to take on the role of participant-as-observer at Johnson Elementary, because prior to the school year of 2014, I was employed as a fifth grade teacher at the site. Two of the three participants from Johnson who agreed to pilot Keeping Equity in Mind were my previous teammates, so I have an insider's view of how the participants at Johnson plan, teach, and assess their lessons. At both Johnson and Sunset, I actively participated in planning the teams' cycles of inquiry. I helped brainstorm ideas for designing engaging lessons, and I helped determine formative and summative assessments. In many ways, I was a member of their teams. However, the participants knew I was gathering data, and they were aware of the fact I was observing their planning meetings while I participated (Johnson \& Christensen, 2008). 
A benefit to being a participant-as-observer is I was able to establish a meaningful identity within the groups (Borg \& Gall, 2003), and I established relationships with the participants, which allowed them to feel comfortable enough in the process to ask hard questions, admit shortcomings, and push my thinking as a researcher. Our rapport allowed us to genuinely communicate as we participated in the implementation of Keeping Equity in Mind. However, this type of authentic interaction did not happen immediately. Johnson and Christensen (2008) described a possible weakness of the participant-as-observer approach is participants may not act completely natural knowing they are being observed. This was apparent in my first observation of teachers planning at Johnson Elementary. A member of the team made several comments about "being a team player" and "anything that is good for the team is good for me," which were clearly directed at me (and the audio-recorder); however, by the time we began planning their first cycle of inquiry, she no longer made such comments.

Another benefit to this approach is I was able to elicit feedback on the process of implementing Keeping Equity in Mind in real time. I was able to observe first-hand what was working and what was not. In addition, I was able to ask participants in the moment what they needed in order to be more successful in implementing a cycle of inquiry in order to help them design targeted instruction for their focal students.

I believe the role of participant-as-observer allowed me to work hand-in-hand with the teacher participants to identify pitfalls and shortcomings of implementing Keeping Equity in Mind. In order to address issues of bias, I allowed participants to 
member check transcripts of observations and interviews in order to comment, correct, or add additional thoughts to their previous comments (Creswell, 2007).

\section{Sample Selection}

The preliminary field test of this study was designed using convenience sampling techniques. Researchers use convenience samples when "they include in their sample people who are available or volunteer or can be easily recruited and are willing to participate in the research study" (Johnson \& Christensen, 2008, p. 238). One limitation to convenience sampling is researchers are unable to make generalizations based on the data they gather, because the sample they have selected is likely not representational of the greater population. However, because the purpose of the preliminary field test in a R\&D cycle is to gather preliminary data in the usefulness of the product — not make generalizations about a particular population-I believe a convenience sample was appropriate.

The main field test of this study was designed using purposive sampling, which allows researchers to select "individuals and sites for study because they can purposefully inform an understanding of the research problem and central phenomenon in the study" (Creswell, 2007, p. 125). In purposive sampling, researchers determine the characteristics desired for their sample, and then locate individuals with those characteristics (Johnson \& Christensen, 2008). In this study, a purposive sample of elementary and secondary teachers in Middleton School District was selected. Criteria for the sample selection were twofold: (a) teachers were currently teaching in the elementary or secondary grade levels in Middleton School District, and (b) teachers had participated in formal equity training 
either at their school sites or through district-wide equity training (see chapter 4 for specific sample demographics).

\section{Research Questions}

In an attempt to help support educators in continuing equity work beyond the end of their professional development training, I designed the handbook, Keeping Equity in Mind: A Tool for Teacher Leaders to Use While Planning Their Lessons in Order to Sustain Equity Work, which focuses on the use of a cycle of inquiry to guide their work when planning lessons for their classrooms. This handbook supported educators in planning for equitable academic outcomes for all of their students, because it focuses on targeting instruction for focal students in order to better design learning objectives for students who have fallen into the academic gap. The primary research question this study aims to answer is: How useful is the handbook, Keeping Equity in Mind: A Tool for Teacher Leaders to Use While Planning Their Lessons in Order to Sustain Equity Work, in building teacher efficacy in regard to teaching their students of color? The handbook is intended to provide support by helping educators understand the cycle of inquiry and how to properly choose and focus on focal students as they plan their weekly lessons. The following questions are secondary questions that guided the evaluation of the handbook:

1. How useful is Keeping Equity in Mind in supporting educators in explicitly thinking of their students of color as they plan their weekly lessons?

2. How useful is Keeping Equity in Mind in helping educators build stronger relationships with their students of color?

3. How useful is Keeping Equity in Mind in helping teacher leaders engage students of color?

4. How useful is Keeping Equity in Mind in building teacher efficacy in regard to teaching students of color? 
5. What are the participants' perceptions of the handbook's content, and usability?

6. What suggestions do the educational leaders have for the improvement of this handbook?

By allowing these research questions to guide my work, I gained insight into the usefulness of the handbook I created in affecting how educators think about their students of color as they plan their weekly lessons. It is my hope that the use of this handbook will become part of a planning routine for educators to ensure their continued commitment to teaching equitably in their classrooms. These questions helped guide revisions to the handbook in order to ensure the final version took into account the input from those who participated in its creation.

\section{Research Design}

After evaluating several research design options for my dissertation work, I came to the conclusion, along with Bridges and Hallinger (1995), that PBL provides "opportunities for practitioners to develop the capacity to apply knowledge from theory and research to problems of policy or practice" (p. 116), and therefore, was the best methodology for the work I was setting out to accomplish. I was especially intrigued by the notion that my research, designed using the PBL process, would not merely be a means to an end, a mere requirement for completing a doctorate degree, but rather would have actual value in the work I plan to do in the future.

\section{PBL}

Because the goal of Ed.D. programs is "to apply knowledge from theory and research to problems of policy or practice" (Bridges \& Hallinger, 1995, p. 116), it makes sense that students pursuing an Ed.D. select a methodology that employs both academic 
and practical goals. The PBL model allows doctoral students to identify research questions that relate directly to problems of educational policy and/or practicewith which they are familiar because they are struggling with them every day in the work they do. I believe the model that lends itself most readily to the pursuit of PBL is the R\&D cycle (Bridges \& Hallinger, 1995). Once a problem in practice has been identified, the researcher reviews the pertinent literature; following a review of the literature, the researcher designs and field tests a product. During this stage of the PBL project, the researcher will develop, field test, and revise a preliminary form of their product. In the final development stages of the product, the researcher conducts a main field test, collects both summative and formative assessment data on the effectiveness of the product, and, finally, makes any necessary revisions to the product to increase its overall effectiveness in addressing the problem of practice (Bridges \& Hallinger, 1995).

Educational Research and Development [R\&D] is an industry-based development model in which the findings of research are used to design new products and procedures, which then are systematically field tested, evaluated, and refined until they meet specified criteria of effectiveness, quality, or similar standards ... it has great promise for improving education because it involves a close connection between systematic program evaluation and program development. (Borg \& Gall, 2003, pp. 569-570)

In the next section, I describe the steps of the R\&D cycle, and discuss what I did at each stage of the process.

\section{R\&D Cycle}

The $\mathrm{R} \& \mathrm{D}$ cycle is a 10 -step process used to convert research findings into products and/or programs which can be used in the field of education (Borg \& Gall, 
2003; Bridges \& Hallinger, 1995; Lorenz \& Pichert, 1989). Table 6 outlines the steps of the $R \& D$ process.

Table 6

The R\&D Process

\begin{tabular}{|c|c|}
\hline Step & Activities \\
\hline Research and Information Gathering & $\begin{array}{l}\text { Preliminary Literature Review } \\
\text { Small-Scale Research }\end{array}$ \\
\hline Planning & $\begin{array}{l}\text { Develop Initial Description of the Product } \\
\text { Determine Target Audience } \\
\text { Continue Literature Review }\end{array}$ \\
\hline Develop Preliminary Form of Product & $\begin{array}{l}\text { Develop the Problem Scenario } \\
\text { Develop Prototype of the Product }\end{array}$ \\
\hline Preliminary Field Testing & "Dry-Run" with a Group that is Similar to Target Group \\
\hline Main Product Revision & Product Revision is Based on Formative Feedback \\
\hline Main Field Testing & $\begin{array}{l}\text { Implement New Product } \\
\text { Collect Data on Implementation }\end{array}$ \\
\hline Operational Product Revision & $\begin{array}{l}\text { Revision Based on Analysis of Data Collected } \\
\text { Formative Data Helps Determine How to Improve Product } \\
\text { Summative Data Helps Determine if the Product is Valuable }\end{array}$ \\
\hline Operational Field Testing & $\begin{array}{l}\text { Determine if the product is ready to use in schools } \\
\text { Begin to prepare others to use tool in school settings }\end{array}$ \\
\hline Final Product Revision & Collect additional data from educators using the tool \\
\hline Dissemination and Implementation & $\begin{array}{l}\text { Making product available to other educators } \\
\text { Publication of product }\end{array}$ \\
\hline
\end{tabular}

Source: Bridges \& Hallinger (1995)

\section{Step 1: Research and information gathering.}

- Define educational problem or need the product will address

- Conduct preliminary literature review

- Informally interview administrators, teachers, and/or others knowledgeable about the problem 
Step 1, research and information gathering, was accomplished through my review of the literature regarding the causes for the racial achievement gap as well as my review of the literature regarding professional development models and their effects on changing teacher practice. This process began in August 2011 and continued into May 2012. In addition, I have had several conversations with teacher leaders and administrators over the past 10 years regarding the difficulty encountered when trying to sustain equity work in schools and classrooms when formal equity training has ended. For the purposes of this study, I reconnected with Julien Phillips, the Vice Chair and Secretary of the organization, Partners in School Innovation.

Informally, I have been involved in this step of the process throughout my entire teaching career. I have worked in Title I schools for the past 11 years; most of which have been spent diligently working to close the achievement gap in my own classroom. I have participated in numerous professional development activities dealing with equity and teaching to improve the educational outcomes for students of color. I have experienced firsthand how frustrating it becomes when formal equity training ends, and one is left to fend for oneself while trying to continue the work begun in a training session or workshop. I have, all too often, seen the efforts of educators to continue equity, work once training has ended, become too frustrating and, therefore, abandoned. In an attempt to help educators, including myself, continue to teach with equity in mind, the development of this handbook became the focus of my doctoral work. 


\section{Step 2: Planning objectives, learning activities, and small-scale testing.}

- Develop description of the product including an introduction, statement of the problem, and learning objectives

- Determine the target audience and venue for testing the product

- Develop formal research proposal

In order to complete step 2 of the R\&D model, in April 2012, I began to write an initial draft of the handbook, Keeping Equity in Mind. I defined the problem, as discussed in chapter 1 of this dissertation, and determined the best way to support educators in continuing equity work in their classrooms is through the use of focal students and a cycle of inquiry. At that time, I also identified the target audience as educators who are dedicated to supporting their students through continued equity work as well as the administrators who support them. Both administrators and teachers will have valuable insight into how this product can be revised to better meet the needs of teachers in the field. Additionally, I determined Johnson Elementary and Sunset High School would be the venues for conducting the main field test of the handbook in order to gather data to support operational revisions.

\section{Step 3: Develop preliminary form of the product.}

- Develop prototype of the product

In April 2012, I began drafting the first draft of Keeping Equity in Mind. I used the information gathered in my literature review as well as the conversations I had with educational administrators and teacher leaders regarding sustaining equity work to guide my initial development of the handbook. I also submitted a draft the handbook to my doctoral advisor for advice and feedback on possible additions to improve the initial 
product. While at the conclusion of step 3, a preliminary draft of Keeping Equity in Mind was completed, it was not until after the preliminary and main field tests that the handbook received more substantial revisions.

\section{Steps 4 and 5: Preliminary field test and main product revision.}

- Conduct a "dry run" to gather initial feedback from members of the target audience

- Data obtained in the preliminary field test is used to make revisions to the product

In September 2013, I conducted a preliminary field test which included 3

administrators, 2 TOSAs (teachers on special assignment) dedicated to equity work in their district, and 5 teachers in Middleton School District (three of which participated in the main field test). The participants previewed Keeping Equity in Mind and made suggestions regarding its possible usefulness. I gathered preliminary data through conversations with the participants as well as collecting anecdotal data written by the participants regarding their opinions of the product. Once I gathered the initial data, I used the findings to determine the main product revisions to the handbook before beginning the main field test.

Three of the participants in the preliminary field test also took part in the main field test in order to ensure they had the opportunity to help design the handbook to meet the specific needs of their classrooms. It was my hope that by allowing the participants of the main field test to participate in the initial preview of the product (as well as others not participating in the main field test) they would feel as though they were part of the creation of the handbook, which made their participation in this process more authentic. 


\section{Step 6: Main field test.}

- Implement the revised product and gather data regarding its implementation

The product was main field tested by three fifth grade teachers at Johnson

Elementary, a Title I elementary school, and three secondary teachers at Sunset High School. Both schools are in the Middleton School District. White and Asian students at Johnson Elementary have met standard on state assessments consistently; however Black and Latino students have not. In addition, English Language Learners and students identified with specific learning differences based on their Individualized Education Plans (IEPs) have not met standard based on their performance on state assessments.

The principal of Johnson Elementary, Sharon, has been there for 7 years and was placed at Johnson in order to "turn the school around" both academically and socially (at the time of her placement, the staff of Johnson was merging with the staff of another elementary school in the district due to school closures). It was her mission to help unify the two staffs while simultaneously raising the achievement of all students, especially those of color, in her building. I spoke to Sharon on several occasions regarding equity work at Johnson. At the time of the preliminary field test, she was participating with a group of principals in a book group reading and discussing Courageous Conversations (Singleton \& Linton, 2006). Some members of the staff at Johnson Elementary had participated in equity workshops and trainings in previous years; however, future equity training is uncertain due to financial restrictions recently placed on professional development. For these reasons, Johnson Elementary was a suitable site for field testing my handbook, because the teachers there had experienced professional development in 
the area of equity and were now expected to continue the work without any formal support.

In addition to working with participants at Johnson Elementary, three secondary teachers at Sunset High School agreed to participate in the study. Sunset High School, a 4-year high school/college transition program in Middleton School District, is dedicated to preparing its students for college classes by transitioning them into college classes through the Pathways to College Program. Many students at Sunset participate in Sunset's College Extended Options program by enrolling in classes at the local community college as well as those at the high school concurrently. The principal of Sunset High School, Dan, expressed interest in participating in the study. He and several teachers from his site had just completed formal equity training, and he was wondering how he could support his teachers in transitioning from theory to practice. He invited me to meet with three of his teachers resulting in their participation in this study.

The participants of the study selected focal students, participated in one to two cycles of inquiry, and evaluated the handbook in order determine its usefulness in supporting teachers with equity work in their classrooms. Formative and summative data were collected during the main field test through interviews, surveys, and observations. The data collected was analyzed in order to inform ways in which the product could be improved during the operational product revision stage of the R\&D cycle (Bridges \& Hallinger, 1995). 


\section{Step 7: Operational product revision.}

- Revise handbook based on the analysis of the formative and summative data gathered

Following the main field test, I conducted operational product revisions to Keeping Equity in Mind in order to support the needs of educational leaders. I did an operational product revision based on the data, both summative and formative, I collected from the main field test.

\section{Steps 8-10: Operational product testing, final product revision, and}

dissemination and implementation. Steps 8-10 of the R\&D methodology are beyond the scope of this dissertation project. Bridges and Hallinger (1995) suggested students working toward obtaining their Ed.D should participate in steps 1-7; leaving steps 8-10 to the discretion of the student. Should I decide, following the completion of the dissertation process, to pursue further testing, revision, and implementation (steps 8-10), it would occur outside of the timeline for this project.

\section{Data Collection}

While the need for sustained professional development in the area of equity has been deemed a priority in order to close the achievement gap (Darling-Hammond, 2007; DeCuir \& Dixson, 2004; Gay, 2000; Howard, 2006), it is clear among those participating in equity training across districts that once the professional development has ended, educational leaders are left with little or nothing with which to support continued equity work with their staffs. In addition, while the literature agrees professional development opportunities should be sustained over longer periods of time, collaborative in nature and grounded in inquiry (Cochrane-Smith \& Lytle, 2001; Little, 2001; McLaughlin \& 
Zarrow, 2001), there is little research that illustrates how this might be done once formal professional development opportunities have ended.

This section discusses the concept of a research paradigm and how it is important for all researchers to determine from which paradigm they will be conducting their research before they begin conducting their research. I then discuss the critical theory paradigm of research, the constructivist theory in particular, and why I decided to design my PBL project using a constructivist approach to the R\&D development cycle in order to determine the usefulness of the tool I developed. Finally, this section ends with a detailed description of the data collection methods I used while gathering data in order to revise and improve upon the original product in order to meet the need of educational leaders and teacher leaders committed to continuing the work of equity as they set out to meet the academic needs of all of their students.

\section{Research Paradigm}

A paradigm is a set of beliefs held by individuals or groups that guide action. It is important to clarify that a research paradigm is a set of beliefs that guide inquiry into an area of interest for the researcher (Johnson \& Christensen, 2008). "Paradigm issues are crucial: no inquirer . . . ought to go about the business of inquiry without being clear about just what paradigm informs and guides his or her approach" (Guba \& Lincoln, 1994, p. 116). According to Guba (1990), paradigms can be characterized by the manner in which their supporters answer the following ontological, epistemological, and methodological questions: “

(1) Ontological: what is the nature of the "knowable"? Or what is the nature of "reality"? (2) Epistemological: what is the nature of the relationship between the 
knower (the inquirer) and the known (or knowable)? and (3) Methodological: How should the inquirer go about finding out knowledge? (p. 18)?

Examining these questions allows researchers to determine from which paradigm they will develop research questions, engage in gathering participants and data, and analyze data in their studies. A researcher operating from a positivist or post-positivist approach is more interested in finding the truth through primarily quantitative measures while researchers working from within the constructivist or critical theory paradigms recognize there is not a "truth" to be found and are more interested in human interactions and how the truth in constructed through experience (Guba, 1990). When considering the examination of a handbook designed to support teacher leaders in their continued commitment to equity through the use of inquiry, it is appropriate that research be designed using either a critical theory or constructivist paradigm.

The critical theory paradigm recognizes that values enter into every inquiry, and therefore, it is necessary to determine whose values (those of the researcher or those of the participants) will govern. Because values enter into every inquiry, it can be concluded that all inquiries, in essence, become political acts (Guba, 1990). The aspect of the critical theory paradigm that sets it apart from the others is its commitment to agency and transformation of participants so that they can act upon the world in a different, more empowered manner. While the aim of those conducting research from within the critical theory paradigm is the "critique and transformation of the social, political, cultural, economic, ethnic, and gender structures that constrain and exploit humankind" (Guba \& Lincoln, 1994, p. 113). I would argue that before one can challenge systems of inequity, one must become privy to their role in perpetuating such inequities. 
My hope is, through the implementation of Keeping Equity in Mind, participants will act upon the world in a more critically informed manner; that is, they will become empowered to teach in a manner that will begin to close the achievement gap, thus transforming the educational system (their classrooms) from an institution that traditionally treats its students of color inequitably to one that consistently analyzes its role in perpetuating the achievement gap, and in doing so, is able to think critically about how to transform practices of inequity.

Constructivists agree with critical theorists that all inquiry is seen through a "value window" (Guba, 1990, p. 25). If research is to be done assessing the effectiveness of a handbook designed to support educators in continued equity work and inquiry once formal professional development has ended, it is essential that researchers embarking on this work do so through a paradigm that recognizes the influence of bias and values on the development and results of research studies. In addition, constructivists believe ontologically that research is the means by which human constructions become better informed, and therefore, more sophisticated (Guba \& Lincoln, 1994). Furthermore, the constructivist inquirer is not seen as the informed intellectual as in the critical theory paradigm. Rather, the constructivist inquirer is seen as "orchestrator and facilitator of the inquiry process" (Guba \& Lincoln, 1994, p. 114). Because my research focuses on the effectiveness of my handbook to support educators, I believe a constructivist approach is appropriate.

As a facilitator in the $R \& D$ process, I was able to support educators in the process of designing a cycle of inquiry in order to meet the needs of their students of color, thus 
supporting them through a transformation of practice. I believe that together, the participants in this study and I set the foundation for continued equity work in their classrooms.

In addition, in an attempt to develop a more productive connection between research, theory, and practice, I decided to conduct my research using Bridge and Hallinger's (1995) PBL model as the framework for the design of my research. The PBL model is appropriate for the research I conducted as it does not view the dissertation process as one that is merely an academic requirement to fulfilling an EdD program, but, rather, it considers the research conducted in an EdD dissertation as having "instrumental value in [the researcher's] future work" (p. 116).

Because teaching for equity is something that extends well beyond the completion of this dissertation, it is important that I develop a handbook that can be used to support educational leaders in the continuation of equity work in their classrooms. For this reason, I agree with Bridges and Hallinger (1995) that a PBL approach is most appropriate for my research goals. While designing research using a PBL model, I developed a product for educational leaders to use in order to ensure they are continuing equity work in their classrooms. I did this by using the R\&D model described by Borg and Gall (2003).

\section{Data Collection Strategies}

Preliminary field test data collection for this study began in September 2013. It included 10 participants representing teachers, administrators, TOSAs, and an instructional coach. The preliminary field test participants read the handbook and 
provided preliminary data regarding their perceived usefulness of the handbook through making marginal notes in the handbook as they read it. In addition, I during the preliminary field test, I engaged in informal conversations with the participants regarding their thoughts of the preliminary form of the product.

Main field test data collection for this study began in January 2014 which included a pre-interview of each participant and a pre-observation of lesson planning at Johnson Elementary. In February 2014, an observation of the actual planning of two cycles of inquiry took place at Johnson Elementary, and an observation of one planning meeting took place at Sunset High School. In March 2014, at the conclusion of the study, all participants participated in a final interview and completed a survey regarding their perceived usefulness of Keeping Equity in Mind.

\section{Anonymity and Confidentiality}

While this study is not about human subjects, rather it is measuring the usefulness of the handbook, Keeping Equity in Mind, ensuring anonymity and confidentiality of participants is still a central component to ethical research methods (Creswell, 2007; Johnson \& Christensen, 2008). All participants signed a consent form agreeing to participate in the interviews and surveys and acknowledged they understood they were allowed to leave the study at any time (Appendix A). I assured the participants I would safeguard the data collected through the use of pseudonyms for each of the participants as well as for the district in which they work. This study is focused on determining the usefulness of Keeping Equity in Mind and not on the participants themselves. 


\section{Interview Protocol}

Interviews were chosen as a data collection technique to obtain in-depth

information about the participants' thoughts regarding the usefulness of Keeping Equity in Mind. An interview is a useful data collection tool because it "permits open-ended exploration of topics and elicits responses that are couched in the unique words of the respondents" (Borg \& Gall, 2003, p. 223). One of the benefits to qualitative interviews, with an open-ended interview approach, is the researcher is open to all possible answers; there are not any right or wrong answers, and all responses are relevant (Schensul, Schensul, \& LeCompte, 1999). In addition, qualitative interviews allow researchers to clarify responses and provide opportunities for the researcher to ask follow-up questions when responses are vague.

Limitations to the qualitative interview include difficulty in standardizing the interview process and the fact that anonymity cannot be achieved for participants being interviewed (Borg \& Gall, 2003). In order to account for these limitations, I designed an interview protocols (Appendices A and B) using the interview guide approach (Johnson \& Christensen, 2008), which ensures all participants are asked the same open-ended questions. In order to address the issue of anonymity, I guaranteed the participants' identities would not be revealed in my report of the data through the use of pseudonyms for each of the participants and the school districts in which they work.

For the purposes of this study, each participant was interviewed before and following the main field test. The equity interview (Appendix B) data served as baseline data to determine how efficacious the participants felt regarding teaching students of 
color in their classroom after participating in equity training, and prior to implementing Keeping Equity in Mind. The final interview protocol (Appendix C) served to demonstrate if there was a change in how the participants felt regarding their ability to teach their students of color equitably following the implementation of Keeping Equity in Mind.

I used a combination of informal conversational interviews and interviews designed using the interview guide approach. Using a combination of the two, I was able to explore all leads that emerged in the conversational interviews as well as ensure I asked all participants a similar set of questions. In doing both, participants were able to guide the discussion on one hand while ensuring certain topics got discussed on the other (Johnson \& Christensen, 2008).

All of the initial equity interviews and the final interviews were done in person. Each participant determined the location of the interviews. The purpose of the initial equity and final interviews was to determine if teachers felt more efficacious teaching their students of color following the implementation of Keeping Equity in Mind. In addition, the final interview served to allow participants the opportunity to voice their opinions regarding the usefulness of the handbook.

The data gathered through the interviews helped to determine what aspects of the handbook needed revision and which areas were most useful. All interviews were audiotaped and transcribed to ensure I captured exactly what each participant was conveying and to diminish bias on the part of the researcher. Once the interviews were transcribed, I read the transcripts multiple times in their entirety in order to "immerse [myself] in the 
details, trying to get a sense of the interview as a whole before breaking it into parts" (Agar, 1980, p. 103). I wrote marginal memos (e.g., phrases, recurring ideas) in order to facilitate the emergence of themes or categories that were presented in the data (Creswell, 2007). The emergent categories became codes for organizing and analyzing the data. I open coded the data in order to ensure it was "reflect[ing] the view of the participants" (Creswell, 2007, p. 152) rather than using prefigured codes. Finally, in order to ensure I captured the participants' authentic voice, I used the technique of member check (Creswell, 2007). I sent a copy of the transcripts to each of the participants, so they could read the interview and add, detract, or clarify anything they felt did not come across as they meant.

\section{Observation Protocol}

Observations are used in qualitative research to allow researchers the opportunity to formulate their own interpretation of what is occurring (Borg \& Gall, 2003). The observations in this study were naturalistic observations, or observations done in the "real world" (p. 211). Prior to introducing Keeping Equity in Mind, I observed (see Appendix D for observation protocol) a planning meeting at Johnson Elementary in order to see the frequency with which particular students of color were discussed by the three teachers. I also observed planning meetings during the implementation of the handbook in order to see if, in fact, the handbook affected the way in which the participants planned their lessons. In addition, I observed one planning meeting at Sunset High School. I took extensive field notes during and immediately following each observation to ensure I captured accurate accounts of what I witnessed. The observations were also audio-taped 
and transcribed in order to ensure authenticity. I gathered this data in a pre- and postobservational setting, at Johnson Elementary, in order to analyze if there was any change in the types of discussions teachers were having following the implementation of the tool.

All observational data were logged in a field journal, audio-taped, transcribed and analyzed in an attempt to identify themes and patterns that arose during the planning meetings. In addition, the observation data collected at Johnson was used to determine if there was a change in teachers' practices before and during the implementation of Keeping Equity in Mind.

\section{Survey Protocol}

Each participant completed a survey (Appendix E) following the completion of the study. The purpose of the survey was to allow the participants an opportunity to give their thoughts regarding the usefulness of Keeping Equity in Mind. It allowed the participants to answer a variety of standardized questions regarding the handbook's design, usability, and overall importance to the field of education. The survey was sent out to each participant electronically via SurveyMonkey.com.

\section{Data Analysis}

It is common for qualitative researchers to alternate between data collection and

data analysis early on in a given research study (Johnson \& Christensen, 2008). Miles and Huberman (1994) described this process as interim analysis: the cyclical process of collecting and analyzing data. I believe interim data analysis lends itself well to the R\&D design process, because it allows researchers to "develop a successively deeper understanding of their research topic and to guide each round of data collection" 
(Johnson \& Christensen, 2008, p. 531). In this section, I discuss how I used interim data analysis to guide my research. In addition, I discuss how I analyzed my final findings in order to determine the next steps for the revision of the handbook.

In qualitative research, data analysis consists of preparing and organizing data for analysis in order to identify themes in the data collected in a given research study (Creswell, 2007). In order to properly analyze the data collected in this study, I began to interpret the data I collected as I collected it; that is, I used the data I collected in the preliminary stages of my study to guide future steps. I began coding, categorizing the data, and identifying relationships, or themes in the data, in order to begin to organize the data. All the while, I was interpreting the data I had collected in order to determine how data collection in the next steps of the study should proceed (Johnson \& Christensen, 2008).

I agree with Creswell's (2007) notion of “lean coding” (p. 152)—beginning with a short list of themes from the data and then expanding that list as the researcher continually reviews their collection of data. From my observations, interviews, and surveys, I compiled an initial list of themes, and from there, I coded the data according to category. As I continued to review the data, I revised the codes and added additional categories as needed. I believe beginning with a smaller list of codes allowed me to focus more clearly on the larger themes evolving from the research in order to see the big picture more clearly. 
In addition to lean coding, I used memoing (Creswell, 2007) as I initially analyzed the data I gathered. Memoing, the practice of taking reflective notes on what one is learning from the data as one analyzes it, allows researchers to recognize emerging themes and patterns as well as postulate possible next steps. In addition, through memoing early on in the process of data collection, I was able to recognize gaps in my data collection, which allowed me to analyze the need for further data collection in a certain area before the research was concluded.

All interviews and observations were recorded and transcribed in order to ensure I captured exactly what all participants said. Audiotaping interviews and observations is an effective practice in collecting data, because it allows researchers to replay events as many times as necessary to appropriately code and quantify the number of times certain themes emerge (Borg \& Gall, 2003).

\section{Validation}

Qualitative researchers strive for "understanding," that deep structure of knowledge that comes from visiting personally with participants, spending extensive time in the field, and probing to obtain detailed meanings. During or after a study, qualitative researchers ask, "Did we get it right?” (Creswell, 2007, p. 201).

In order to check the accuracy of my study, I used the following validation strategies:

1. Triangulation: This study included multiple methods of data collection (i.e., interview, observation, and survey) in order to corroborate its findings (Borg \& Gall, 2003; Creswell, 2007; Guba \& Lincoln, 1994; Johnson \& Christensen, 2008). Triangulation "often can unearth patterns as responses, items, events, or themes from various sources of data [which] begin to corroborate one another" (LeCompte \& Schensul, 1999, p. 102). When emerging themes in the 
data were complementarity, I was able to elaborate or enhance the information I gathered using one data collection method with data I collected using another. For instance, when participants reported leaving equity training with little to no practical applications for their classrooms in the initial interview, I was able to elaborate and corroborate this phenomenon while observing and participating in the development of their cycles of inquiry.

2. Clarifying Researcher Bias: It is important researchers are transparent regarding their bias in research studies (Creswell, 2007). For this reason, prior to the beginning of the study, I met with the participants in order to be upfront about my assumptions regarding equity training and its limitations in regard to practical teaching applications. I explained to the participants that I had, in my first years of teaching, gone through the process of selecting focal students and designing targeted lessons through the use of a cycle of inquiry. I clearly stated that my assumption was the process worked, which is why I designed the handbook. I explained what I anticipated my role in the study would be that of participant-as-observer-I would be engaged in the planning and designing of each cycle of inquiry, and I planned to be a resource to the teachers as they planned lessons.

3. Member Checking: Lincoln and Guba, (1985) described member checking as "the most critical technique for establishing credibility" (p. 314) in qualitative research. Member checking involves allowing the participants in a study to review data, analyses, interpretations and conclusions in order to give them the opportunity to examine the researcher's findings, which gives them the opportunity to provide "alternative language, critical observations or [different] interpretations" (Creswell, 2007, p. 209). Following each interview, I sent the participants the transcripts to their interviews electronically, so they could have the opportunity to clarify their thinking.

\section{Work Plan}

Table 7 highlights the work plan that drove this research. 
Table 7

Work Plan

\begin{tabular}{|c|c|c|}
\hline Month & Activity & $\begin{array}{l}\text { Stage of Product } \\
\text { Development }\end{array}$ \\
\hline $\begin{array}{l}\text { August 2011- } \\
\text { May } 2012\end{array}$ & $\begin{array}{l}\text { Determined product would be a handbook for teacher } \\
\text { leaders and their administrators to support continued } \\
\text { equity work in the classroom once formal equity } \\
\text { training had ended } \\
\text { - Conducted review of the literature }\end{array}$ & $\begin{array}{l}\text { Step 1: Research and } \\
\text { Information Gathering }\end{array}$ \\
\hline April 2012 & $\begin{array}{l}\text { - Defined the problem to be addressed by the handbook: } \\
\text { continued equity support for educational leaders } \\
\text { - Determine the target audience: teacher leaders and the } \\
\text { administrators who support them }\end{array}$ & $\begin{array}{l}\text { Step 2: Planning } \\
\text { Objectives, Learning } \\
\text { Activities, and Small- } \\
\text { Scale Testing }\end{array}$ \\
\hline April 2012 & $\begin{array}{l}\text { - Began the first draft of Keeping Equity in Mind based } \\
\text { on the information gathered in steps } 1 \& 2\end{array}$ & $\begin{array}{l}\text { Step 3: Develop } \\
\text { Preliminary Form of the } \\
\text { Product }\end{array}$ \\
\hline September 2013 & $\begin{array}{l}\text { - Participants from Johnson Elementary as well as } \\
\text { several other administrators, counselors, and teachers } \\
\text { participated in a preliminary "dry-run" field test of the } \\
\text { product. They reviewed the handbook and offered } \\
\text { insight to possible revisions prior to the main field test } \\
\text { - Collected data to facilitate revision of product prior to } \\
\text { conducting the main field test }\end{array}$ & $\begin{array}{l}\text { Step 4: Preliminary } \\
\text { Field Testing }\end{array}$ \\
\hline $\begin{array}{c}\text { October- } \\
\text { December } 2013\end{array}$ & - Revised handbook based on preliminary feedback & $\begin{array}{l}\text { Step 5: Main Product } \\
\text { Revision }\end{array}$ \\
\hline January 2013 & $\begin{array}{l}\text { - Met with participants participating in the main field test } \\
\text { - Conducted initial interviews with participants } \\
\text { - Conducted observations of planning meetings prior to } \\
\text { and during implementation of the tool } \\
\text { - Conducted final interviews and survey regarding the } \\
\text { effectiveness of the tool }\end{array}$ & $\begin{array}{l}\text { Step 6: } \\
\text { Main Field Test }\end{array}$ \\
\hline $\begin{array}{l}\text { February-March } \\
\quad 2014\end{array}$ & - Analyzed data & Step 6: Main Field Test \\
\hline March 2014 & $\begin{array}{l}\text { - Determined revisions to be made based on the data } \\
\text { collected in during the main field test }\end{array}$ & $\begin{array}{l}\text { Step 7: Operational } \\
\text { Product Revisions }\end{array}$ \\
\hline April 2014 & - Finished writing of dissertation & \\
\hline May 2, 2014 & - Defended Dissertation & \\
\hline
\end{tabular}




\section{Chapter Summary}

This chapter explained the reasons why I chose to design this study using PBL employing the R\&D cycle, and how this process lends itself well to educational research. It highlighted the PBL process and briefly described what I did at each stage of the development process. In addition, it discussed the data collection strategies employed in this research study as well as how the data were analyzed. Finally, it concluded with a timeline of the data collection process. Chapter 4 discusses the data collected and its analysis in relation to the research questions guiding this study in further detail. In addition, Chapter 4 discusses the preliminary and main field testing and the main and operational product revisions made to the handbook as a result of the data collected. 


\section{CHAPTER IV}

\section{DATA ANALYSIS}

\section{Chapter Overview}

This research study is based on determining the usefulness of the handbook, Keeping Equity in Mind: A Tool for Teachers to Use While Planning Their Lessons in Order to Sustain Equity Work. The purpose for the handbook is to guide teacher leaders in the pursuit of implementing equitable teaching practices in their classrooms once formal equity training has ended in their school districts. In my experience, and the experience of those participating in this study, equity training is transformative-it leaves those who participate changed and inspired to take on the challenge of closing the achievement gap for students of color in their classrooms. However, those participating in equity training often find themselves at a loss once training has ended in identifying equitable teaching practices they can implement in their classrooms. For this reason, teacher leaders and administrators would benefit from a handbook designed to help them identify focal students, plan engaging lessons, gather pre-, post- and formative data to drive instruction, and build strong relationships with their students of color in order to increase their engagement.

This study was driven by my experience teaching in California, where I saw teachers, myself included, engage in inquiry and begin to close the achievement gap one student at a time. Because we focused on particular students of color, intentionally built stronger relationships with them, and planned lessons that were engaging and motivating, 
we saw steady gains in the academic performance of those students. While we were focusing our instruction on our focal students specifically, we saw academic growth with all our students. The targeted, engaging instruction we were designing for our focal students was increasing engagement for all the students in our classes. We attributed this to the ripple effect (Kidd \& Congdon, 2007) — as a result of a single action (planning lessons specifically for focal students), we saw incremental academic growth for the majority of our students.

This chapter begins with a review of the research questions that guided this study. In addition, it discusses the goals of the study as well as the development and implementation of the PBL Project. I highlight the actions I took at each of the seven steps of the R\&D cycle (Borg \& Gall, 2003), and finally, this chapter ends with an analysis of the usefulness of Keeping Equity in Mind in supporting teachers while they continue equity work in their classrooms.

\section{Review of the Research Questions and Goals}

This study is theoretically grounded in Bridges' and Hallinger's (1995) PBL and Borg and Gall's (2003) R\&D process. The purpose of this study is to determine the usefulness of Keeping Equity in Mind to teacher leaders as they attempt to continue equity work in their classrooms once formal equity training has ended. This study was designed using the first seven steps of the R\&D process, which includes a number of data collection procedures utilized in order to determine areas of strength and weakness in regard to the usability of the handbook. 
Through implementing steps 1-7 of the R\&D process, I was able to develop, field test, and refine Keeping Equity in Mind, so it can be most useful in supporting teacher leaders who are continuing equity work in their classrooms as well as administrators who are attempting to support them. By gathering data regarding the usefulness of this handbook, I was able to revise Keeping Equity in Mind to meet the specific needs of teacher leaders in the field - this study provides the field of education with a tested product that is ready for operational use in schools.

\section{Review of the Research Questions}

The following primary and secondary research questions guided the development of this study.

Table 8

Primary and Secondary Research Questions

Primary Research Question

How useful is the handbook, Keeping Equity in Mind: A Tool for Teacher Leaders to Use While Planning Their Lessons in Order to Sustain Equity Work, in building teacher efficacy in regard to teaching their students of color?

Secondary Research Questions

1. How useful is Keeping Equity in Mind in supporting educators in explicitly thinking of their students of color as they plan their weekly lessons?

2. How useful is Keeping Equity in Mind in helping educators build stronger relationships with their students of color?

3. How useful is Keeping Equity in Mind in helping teacher leaders engage students of color?

4. What are the participants' perceptions of the handbook's content and usability?

5. What suggestions do the educational leaders have for the improvement of this handbook? 
Useful is defined as practical information that is easily applied in the everyday practices of teacher leaders. In addition, useful is defined as whether or not the handbook meets the teacher leaders' current needs in continuing equity work in their classrooms.

\section{Review of Research Goals}

The goals of this study were twofold: (a) to determine the usefulness of the handbook, Keeping Equity in Mind, in supporting teacher leaders as they continue equity work in their classrooms once formal equity training has ended; and (b) to provide teacher leaders and administrators with a product that has been field tested and is ready for operational use in their school sites and/or classrooms. The goals of this study were achieved by designing and conducting a preliminary field test of the handbook in order to gather information to guide the main product revision of the product to meet the specific needs of teacher leaders attempting to close the achievement gap in their classrooms. Following the preliminary field test and main product revisions, the handbook was field tested again (main field test) in order to get further data on the usefulness of the tool in order to make operational revisions to the product to better meet the needs of those participating, and, ultimately, those who might use it in the future. In the next section, I discuss the specific activities I implemented in completing the first seven steps of the R\&D process.

\section{Development and Implementation of the PBL Project}

\section{Step 1: Research and Information Collecting}

The initial step in the $R \& D$ process is identifying a problem or set of issues which will be addressed by the product developed by the researcher (Bridges \& Hallinger, 
1995). After spending the first years of my teaching career at Cole Elementary, racial equity in the classroom was at the forefront of my mind. As I began applying for teaching jobs in Oregon, I was surprised how little I was asked regarding the academic achievement gap for students of color. I planned to share the success we had had in CA during my interviews, but much to my dismay, no one asked. I realized the districts I was applying to did not have an equity mindset, nor did they plan to hire teachers who taught through an equity lens. I hoped once I got to the school site where I was hired, it would be different; I hoped to hear the buzz of teachers discussing the racial equity gap and what they were doing to specifically support the academic growth of their students of color. I hoped to see teachers analyzing the data of the academic performance of their students of color, and I hoped to jump in right where I left off at Cole. It became clear right away that I was a fish out of water.

I spent the next several years talking informally with teachers about race and how it affects the way we teach our students of color. I would discuss privilege and how it affects our lives as White individuals and how it affects the lives of those of color. I spoke of my experience at Cole Elementary and shared my trials and successes in the work we did to begin to close the academic achievement gap for students of color. These lunchtime conversations began to become more frequent with certain teachers; especially when Johnson Elementary's students of color were not meeting standard at the same rate as their White and Asian peers several years in a row. I could see some teachers at Johnson wanted to talk about race; clearly, others did not. 
In the 6 years I have taught at Johnson, the achievement gap has become a more common discussion. Teachers in the district are now participating in equity training through participation in Taking it Up, a 2-day seminar focused on

helping educators, school board leaders, and community members deepen their understanding of the institutionalized racist barriers that hinder elimination of Oregon's racial achievement disparities. This focus working on the inside out will challenge participants to step out of their comfort zone and create new entry points for becoming aware of, understanding, and interrupting inequitable policies and practices in our schools. Oregon Center for Educational Equity, n.d., para.1)

As a result of participating in Taking it Up, participants can expect to

- Better understand how one's identity affects how they teach and lead

- Understand Oregon's racial history and how it affects racial achievement disparities

- Define race, racism, oppression, and white privilege and how it is institutionalized in Oregon's schools

- Discuss how racism has affected the learning outcomes of students of color

- Develop an action plan for discussing the effects of racism on student achievement on a school-wide level.

At this point, participation in Taking it Up is voluntary, though the district hopes to train all of its teachers in the next several years. The problem, however, is once the training has ended, the participants do not have an action plan for how to begin to address these inequities in their classrooms.

Therefore, when asked by my doctoral advisor to identify a problem in the field of education, I immediately thought of the need of a product teachers could use to address the inequities they discuss in equity training through equitable teaching. I decided to design a handbook that would give educators step-by-step instructions on how to focus on their students of color as they planned their lessons. My next action was to ask the 
question: does this product answer the salient questions set forth by Borg and Gall (2003), and therefore, meet the requirements for a R\&D project based in PBL? Table 9 outlines the four salient questions and how they helped determine the appropriateness of designing a handbook to support teacher leaders in continued equity work.

Once the four salient questions set forth by Borg and Gall (2003) had been appropriately addressed, I knew the product I planned to design would, indeed, meet a need in the field of education to support teacher leaders as they set out to continue equity work in their classrooms once formal equity training in their districts had ended. This product answers the question I have heard many teachers ask once formal equity training has ended, "What now?"

Small-scale research. Once the topic of the handbook had been determined, I began to conduct small-scale research, which includes, "observations in schools and interviews with practitioners and researchers who are knowledgeable about the problem" (Bridges \& Hallinger, 1995, p. 120). I began to have informal discussions with teachers I worked with as well as with administrators and literacy coaches. In addition, I called upon Julien Phillips, the Vice Chair and Secretary of the organization, Partners in School Innovation (n.d.).

Partners in School Innovation is a nonprofit organization that accelerates, strengthens and sustains improved teaching, learning and achievement in underperforming schools and districts ... [They] currently serve over 850 teachers and 15,000 students in more than 21 schools across 5 districts and 2 states. [Their] focus is on serving African American, Latino and English-language learners in low-income communities by working shoulder-to-shoulder with teachers and leaders on instruction, leadership and teacher professional development in order to advance educational equity through school-based reform. (para. 1) 
Table 9

Salient Questions for R\&D Product Determination

\begin{tabular}{|c|c|}
\hline Salient Question & $\begin{array}{l}\text { Answer in Regard to Need for Product Designed to Support } \\
\text { Teacher Leaders in Continued Equity Work }\end{array}$ \\
\hline $\begin{array}{l}\text { 1. Does the proposed product meet an } \\
\text { important educational need? }\end{array}$ & $\begin{array}{l}\text { A handbook designed to meet the needs of educational leaders } \\
\text { attempting to continue equity work in their classrooms once } \\
\text { formal equity training has ended does meet an important } \\
\text { educational need. Districts across the country are asking their } \\
\text { teachers to transform their beliefs about race and how it } \\
\text { affects learning. It is not uncommon for teachers in today's } \\
\text { classrooms to still teach from a colorblind lens. That is, they } \\
\text { treat all children equally, or the same. It is teaching through } \\
\text { this type of lens that contributes to the broadening of the } \\
\text { achievement gap for students of color in our classrooms (Gay, } \\
2000 \text { ). For this reason, teachers need a product that will help } \\
\text { them look at their students of color specifically in order to } \\
\text { intentionally design lessons that will engage, motivate, and } \\
\text { inspire so educators can begin to see the academic disparities } \\
\text { between their students of color and their White and Asian } \\
\text { counterparts diminish. }\end{array}$ \\
\hline $\begin{array}{l}\text { 2. Is the state of the art [in relation to } \\
\text { the need or problem] sufficiently } \\
\text { advanced that there is a reasonable } \\
\text { probability that a successful } \\
\text { product can be developed? }\end{array}$ & $\begin{array}{l}\text { Yes. It is clear from the review of the literature that the state } \\
\text { of the art is sufficiently advanced, and, therefore, it is } \\
\text { reasonable to assume a successful product can be developed. }\end{array}$ \\
\hline $\begin{array}{l}\text { 3. Are personnel available who have } \\
\text { the skills, knowledge, and } \\
\text { experience necessary to build this } \\
\text { product }\end{array}$ & $\begin{array}{l}\text { Yes. I believe I have the skills, knowledge, and experience } \\
\text { necessary to build this product. Because of my work at Cole } \\
\text { Elementary, I have insider knowledge of how a cycle of } \\
\text { inquiry can allow educational leaders to intentionally plan } \\
\text { their lessons with their students of color in mind. As a result } \\
\text { of focusing specifically on their students of color, I have seen } \\
\text { teachers begin to think differently about the academic } \\
\text { capabilities of their Black and Latino students. I have used } \\
\text { strategies that have engaged students who have been } \\
\text { traditionally disengaged in school, and I have built } \\
\text { relationships with students in order to bridge the gap between } \\
\text { disengagement and motivation. I have seen the academic } \\
\text { achievement gap for students diminish as a result of the } \\
\text { intentional decisions made by teacher leaders through the } \\
\text { process of selecting focal students and using a cycle of } \\
\text { inquiry. }\end{array}$ \\
\hline $\begin{array}{l}\text { 4. Can the product be developed } \\
\text { within a reasonable period of time? }\end{array}$ & $\begin{array}{l}\text { Yes, this product can be developed within a reasonable period } \\
\text { of time. }\end{array}$ \\
\hline
\end{tabular}

Source Borg \& Gall (2003) 
I had the opportunity to work "shoulder-to-shoulder" with Phillips while I engaged in equity work at Cole Elementary. He and his team helped support our district's efforts in closing the academic achievement gap through equity training, continued professional development, sustained coaching, and a focused approach to intentionally designing learning opportunities for our students of color. I knew the three to five year commitment necessary to work with Partners in School Innovation is not realistic for all districts. My hope was to gain insight into Partners' use of a cycle of inquiry and focal students, so I could author a handbook that teachers could use in their classrooms that would walk them through the process through which Phillips and his team led the teachers at Cole. I asked Phillips how his organization came to focus on three to five focal students.

I believe that we at PartnersSI came up with the practice of selecting 3-5 focal students. I think others may have been talking target students earlier, but with a somewhat different purpose in mind-more like 'bubble students,' whereas our focal-student practice aimed at leading teachers to develop real understanding of a few (initially) students of color for whom their teaching was not working well enough. (J. Phillips, personal communication, January 30, 2012)

Phillips also stated why he felt concentrating "inquiry on what instructional practices are enabling students (first of all, focal students) to achieve the targets and objectives-and where students fall short, what changes, re-teaching in a new way, or other intervention is needed" (personal communication, January 30, 2012) allowed teachers to make the most meaningful gains in their instruction.

Phillips put me in touch (through electronic mail) with Jaime Kidd, Managing Director of Program Development \& Support at Partners in School Innovation in hope 
that she could share some of the resources they used in designing the Results-Oriented Cycle of Inquiry process used at Partners. Kidd sent the following information:

I don't believe I ever knew Teri personally, but her name is certainly familiar to me. Here are a couple of resources:

- About Focal Students-the paper Lisa Congdon and I put together a few years back that describes our thinking and the research base behind the focal student strategy

- Chapter 2 from our Field Guide-this chapter has a description of ROCI [Results Oriented Cycle of Inquiry] contained within

- Research Behind Our Approach-this annotated bibliography cites several resources that we frequently draw on in our work-this may be generally helpful as she's trying to connect to research that we draw upon. (personal communication, January 31, 2012)

The correspondences with Kidd and Phillips began the initial searches I

conducted while writing the review of literature regarding the use of cycles of inquiry for sustained equity work. In addition, in their paper, About Focal Students, Kidd and Congdon (2007) discussed the importance of choosing specific focal students and specifically targeting instruction to meet the needs of students of color in classrooms.

In addition to conducting small-scale research, I began to write the literature review which would guide this study. The review of literature focused on the following topics:

- What Teachers Believe is Causing the Achievement Gap

- Professional Development Approaches

- Teacher Learning

- Why Professional Development Does Not Work

- Inquiry-Based Professional Development 
Step one of the R\&D process, research and information gathering, allowed me to better understand the problems leading to the racial achievement gap in our country as well as how we might begin to close it. After conducting a review of the literature and small-scale research, I was ready for step two of the R\&D cycle: Planning Objectives, Learning Activities, and Small-Scale Testing.

\section{Step 2: Planning Objectives, Learning Activities, and Small-Scale Testing}

Step 2 of the R\&D cycle allows the researcher to identify and develop an initial description of the product (i.e., develop an introduction, problem, and possible learning objectives) as well as make considerations for the target audience (Bridges \& Hallinger, 1995). It was at this point in the study that I determined my target audience - teacher leaders attempting to continue equity work in their classrooms as well as the administrators who support them. I anticipated this product being used in one of two ways: (a) by teachers who had completed formal equity training and wanted a resource that would support them in implementing teaching strategies that would help them teach in a more equitable manner, and (b) by administrators committed to supporting their teachers in continued equity work at their school sites.

While this handbook is written for teachers, it supports educational leaders (i.e., administrators, instructional coaches, super intendants, etc.) in continuing the support of their teaching staffs. Often, following professional development, teachers ask the obvious question, The professional development was great, but what can I do in my classroom tomorrow (McElhone \& Tilley, 2013). It is my hope the handbook, Keeping Equity in Mind, will be a resource administrators can give individual teachers or use as an entire 
staff to ensure equity work starts in the classrooms of their teachers immediately following equity training.

Once I identified the target audience, the following questions guided the development of an outline for the handbook:

1. What will teachers need to know regarding my experience in order to feel confident in implementing a cycle of inquiry in their classrooms focused on specific focal students?

2. How much theory regarding race and privilege should I include in the handbook? Will too much theory and jargon turn educational leaders off to the idea of implementing the handbook? Is it fair to assume they have enough theory considering they have recently participated in equity training?

3. How much will teachers want to read? Is length something that might turn teachers off to the handbook? What is an appropriate length of a tool for teachers attempting to continue equity work in their classrooms?

4. What types of strategies should I include to make the process clear and accessible?

Based on the above questions, I developed an outline for the preliminary form of the handbook (see Table 10).

Before developing a preliminary form of the product, which would be completed in step three of the R\&D cycle, I informally shared the outline of the preliminary form of the product with colleagues at Johnson Elementary as well as my doctoral advisor. The majority of the teachers I talked with mentioned they would not want to be bombarded with jargon and theory; rather, they wanted a "down and dirty" tool they could use as a "reference guide" and a "jumping off point" for beginning equity work in their classrooms. For that reason, I chose to include a short theoretical discussion in the Why Equity Work Matters section and focus the majority of the handbook on walking teacher leaders through the process of designing and implementing a cycle of inquiry on a 
Table 10

Outline for Preliminary Form of the Product

I. About the Author

a. Cole Elementary

i. In $2^{\text {nd }}$ year of Program Improvement

ii. Teachers blamed students for underachievement

iii. Began to do equity training

1. Began to see that we could not blame the students; we had to look at what we could do differently

2. Partners

3. EdEquity

4. Focal Students

iv. Went from $2^{\text {nd }}$ year of Program Improvement to California Distinguished School

II. Why Does Equity Work Matter?

a. Gaps in educational outcomes for students of color

b. By 2050, estimated population will increase by $50 \%$

i. $90 \%$ of increase will be Black and Latino

c. Statistics show that young Black students are only half as likely and Latino students only one-third as likely to earn a bachelor's degree as White students

III. Introduction

IV. Getting Started

a. How do we determine focal students

i. Deciding as a school

ii. Deciding as a team

iii. Deciding as an individual

b. Focal students

i. Definition

ii. Achievement Zones

1. Red

2. Yellow

3. Green

iii. Tool for Identifying Focal Students

c. Cycle of Inquiry

i. Definition

ii. Why Should We Use a Cycle of Inquiry

iii. Cycle of Inquiry Process

d. Continuing the Process

e. Resources 
specific standard in their classrooms. The cycle would focus on lesson design, data collection and analysis, and have an emphasis on engaging and motivating focal students - specific students of color. Once I had outlined the objectives and activities to be included in the handbook, I was ready to develop the preliminary form of the product.

\section{Step 3: Develop Preliminary Form of the Product}

This step of the R\&D cycle "involves the development of the problem scenario and the other facets that compose a PBL project. The outline or prospectus proposed in the previous stage is fleshed out into a fully developed prototype of the product" (Bridges \& Hallinger, 1995, p. 121). Based on the information I gathered in both the first and second steps of the R\&D cycle, I developed a preliminary form of the product, Keeping Equity in Mind: A Tool for Teacher Leaders to Use While Planning Their Lessons in Order to Sustain Equity Work. The preliminary form of the handbook included the following sections:

- About the Author: This section describes the work I did at Cole Elementary in CA and served to add credibility to the handbook. I wanted readers to know I had participated in a similar process while teaching in CA, so they would not think I was just another person telling them what to do to solve their problems. Instead, I wanted them to see me as a colleague - someone who had once been in their shoes. I wanted readers to understand how, through a similar process as those presented in Keeping Equity in Mind, I was able to see academic growth with my students, especially my students of color.

- Why Does Equity Work Matter: This section introduces some of the literature regarding why the academic gap exists for students of color. While I did not want the handbook to be overly theoretical, I felt it was important to include a brief discussion of the literature regarding the achievement gap and its potential effects on society if allowed to persist.

- Equity versus Equality: I felt it was necessary to include a brief discussion regarding the difference between teaching equally and equitably. If teachers are unclear about the differences between the two, they may continue to teach all students equally - that is, they may continue to teach through a colorblind lens. 
The purpose of this section is to discuss how, in order to teach equitably and begin to close the achievement gap, teacher leaders need to abandon the idea of teaching all kids exactly the same and embrace the idea of equity-meeting every child where they are academically in order to support them in continued academic growth.

- How Does a Cycle of Inquiry Support My Work with Common Core Student Learning and Growth Goals: This section discusses how, as a result of using the strategies presented in Keeping Equity in Mind, readers will be able to closely monitor their students' learning and growth for particular standards. Through implementing the handbook's processes, readers will be able to directly connect the learning and growth goals they set with their administrators to the work they are doing in their classrooms.

- Getting Started: The purpose of the Getting Started section is to walk readers through the process for determining focal students. It explains how readers might do so as an entire school, a grade level team, or as an individual. I wanted to ensure all teachers could access this handbook regardless if they were working alone or with a team.

- Focal Students: The section dedicated to focal students introduces readers to the idea of focal students and how data can be used to determine which students could be selected as focal students for their cycles of inquiry. The section discusses the different performance levels (i.e., limited progress toward standard, progressing toward standard, meets standard, and exceeds standard), and how focal students should be identified from those performing in the limited progress toward standard and progressing toward standard levels. In addition, this section provides data collection sheets that allow teacher leaders to see their entire class' data for a particular standard in a single glance.

- Cycle of Inquiry: This section discusses in detail the process of a cycle of inquiry and how it can support teachers in planning lessons in order to engage and motivate their focal students. The section introduces readers to the five steps of a cycle of inquiry: (a) Determining a Focus for Inquiry into Practice, (b) Determining Measurable Goals, (c) Creating an Action Plan, (d) Collecting and Analyzing Data, and (e) Setting Goals for Next Cycle of Inquiry. This section presents readers with guiding questions for each of the five steps of a cycle of inquiry and a step-by-step process for designing lessons using a cycle of inquiry.

- Building Strong Relationships with Your Focal Students: This section introduces several strategies teachers can use in order to build strong relationships with their students. Some of the strategies highlighted include interviewing students, attending extracurricular activities, writing personal notes to students, and making positive phone calls home. 
- Equitable Teaching Strategies: This section presents readers with several basic teaching strategies that promote equity in their classrooms including, but not limited to greeting students by name as they enter the door, think/pair/share, using random response strategies, and asking higher order questions of all students.

- Formative Assessment Strategies: The purpose of this section of the handbook is to support teachers with quick and easy strategies for assessing their students formatively. It gives a brief discussion regarding the differences between summative and formative assessment and includes, but is not limited to, the following formative assessment strategies: Three Dos and a Don't, using individual dry erase boards, using self-directed responses, and Yes/No Charts.

Once the preliminary form of the handbook was complete, I was ready to begin the preliminary field test of the product.

\section{Steps 4 and 5: Preliminary Field Testing and Main Product Revisions}

Once the preliminary form of the product was developed, I began to plan for and implement the preliminary field test of Keeping Equity in Mind. The preliminary field test included 10 participants, which included 3 administrators, 2 TOSAs (teachers on special assignment) dedicated to equity work in their district, and 5 teachers teaching in Middleton School District in Oregon (including three participating in the main field-test).

The participants in the preliminary field test represent a convenience sample of educators who range in experience from 4 to 24 years in the field of education. I purposely included participants in the preliminary field test sample who had not participated in Taking it Up, the equity training adopted by the Middleton School District, because I wanted to understand what their impression of the product would be having not participated in equity training. While this sampling was one of convenience, it was "representative of the target audience" (Bridges \& Hallinger, 1995, p. 120), and, 
therefore, critical feedback could be gathered. Table 11 illustrates the preliminary field test participant demographics.

Table 11

Preliminary Field Test Participant Demographics

\begin{tabular}{|c|c|c|c|c|c|c|}
\hline Participant & Gender & Race & Job Title & $\begin{array}{l}\text { Total \# of } \\
\text { Years in } \\
\text { Education }\end{array}$ & $\begin{array}{c}\# \text { of Years } \\
\text { in Current } \\
\text { Position }\end{array}$ & $\begin{array}{l}\text { Equity } \\
\text { Training }\end{array}$ \\
\hline Kate & Female & White & $5^{\text {th }}$ Grade Teacher & 20 & 6 & Taking it Up \\
\hline Audrey & Female & White & $5^{\text {th }}$ Grade Teacher & 17 & 1 & Taking it Up \\
\hline Jessa & Female & White & $5^{\text {th }}$ Grade Teacher & 11 & 2 & Taking it Up \\
\hline Mary & Female & White & Equity TOSA & 11 & 1 & Taking it Up \\
\hline Allison & Female & White & Equity TOSA & 17 & 1 & Taking it Up \\
\hline Mitchell & Male & White & $3^{\text {rd }}$ Grade Teacher & 4 & 4 & None \\
\hline Sharon & Female & White & $\begin{array}{c}\text { Elementary } \\
\text { Principal }\end{array}$ & 20 & 12 & Taking it Up \\
\hline Tina & Female & White & $\begin{array}{l}\text { Instructional } \\
\text { Coach }\end{array}$ & 24 & 3 & None \\
\hline Donald & Male & $\begin{array}{l}\text { Mixed } \\
\text { Race }\end{array}$ & $3^{\text {rd }}$ Grade Teacher & 12 & 5 & Taking it Up \\
\hline Lidia & Female & White & $\begin{array}{c}\text { Child } \\
\text { Development } \\
\text { Specialist }\end{array}$ & 23 & 6 & None \\
\hline
\end{tabular}

Purpose of preliminary field testing. The purpose of the preliminary field test is to gather formative data regarding the usefulness of the preliminary form of the product (Bridges \& Hallinger, 1995). Because I hope this product will be useful for teachers and administrators, I purposely chose to include both in the sample. The preliminary field test included the following activities:

1. Initial meeting to introduce myself and go over expectations

2. Disseminate preliminary form of Keeping Equity in Mind 
3. Discuss dates for completion of participation and deadlines for feedback

4. Collect and analyze formative data

Each participant was asked to write anecdotal notes in the handbook regarding their opinions of each of the sections and make suggestions for additions to or deletions from the handbook.

All members of the preliminary field test attended the informational meeting, which included a power point presentation (Appendix F) regarding their potential participation in this study. I told my story as an educator working to close the achievement gap and discussed the work I did at Cole. The informational meeting focused on the following topics:

- Purpose of our work together

- How were the participants feeling about equity since training had ended

- Equity versus Equality

- Focal Students

- Cycle of Inquiry

- Expectations for next meeting

Following the informational meeting, each participant received a copy of Keeping Equity in Mind and was given three weeks to read the handbook in its entirety. As the participants read the handbook, they were asked to take marginal notes regarding their perceptions of the product and its perceived usefulness, as well as write anecdotal notes regarding what needed to be added to or omitted from the handbook. While the preliminary field test participants did not actually participate in implementing Keeping 
Equity in Mind, my goal was to ascertain whether or not they felt they would be able to do so after reading the handbook. As I analyzed the formative data gathered during the preliminary field test, the following themes emerged: (a) the handbook's alignment with Senate Bill 290 (SB290; Hungerford \& Dickson, 2012); (c) the usefulness of each of the sections; (c) possible additions; and (d) the appropriateness of certain word choices. The next section discusses these themes in more detail.

\section{Preliminary field test findings (Step 4) and main product revisions (Step 5).}

The preliminary field test yielded formative data, which led to the main revision of the product, Keeping Equity in Mind. While coding the data, I kept the primary research question in mind: How useful is the handbook, Keeping Equity in Mind, to educators continuing equity work in building teacher efficacy in regard to teaching their students of color? Once the participants had read and made marginal notes regarding their opinions of the product, I categorized and coded the data. Through coding the data, themes began to emerge, which drove the majority of the revisions made to the preliminary form of the product.

The first theme that emerged from the preliminary data set was the selection of focal students and setting specific goals for their achievement and its connection to SB290 (Hungerford \& Dickson, 2012). With the passage of SB290 in 2011 and Oregon's Elementary and Secondary Education Act (ESEA)'s Flexibility Waiver in 2012, educators are asked, as part of the teacher evaluation process, to specifically address student learning and growth through the collection of summative and formative assessment data (Hungerford \& Dickson, 2012). Based on SB290 and the ESEA waiver, 
teacher evaluations now require multiple measures of performance-including impact on student learning and growth (Hungerford \& Dickson, 2012).

In the preliminary form of the product, there was no mention of SB290 (Hungerford \& Dickson, 2012) and how it relates to setting measurable goals for focal students through participating in a cycle of inquiry. Participants reported, "this looks a lot like our new growth goals," and, "I wonder how you can make this fit with our growth goals, since we are already doing those . . could they be connected somehow?" In order to bridge the gap and make the connection between SB290 (Hungerford \& Dickson, 2012) and the use of a cycle of inquiry to focus instruction on specific focal students, I added the section, How Does a Cycle of Inquiry Support My Work with Common Core Student Learning and Growth Goals, in order to begin the discussion regarding the usefulness of this tool in helping teachers meet their student learning and growth goals. I decided, however, not to completely revise the Determining Focal Students section at this point. Rather, I determined it made more sense to wait until I began working with teachers in the main field test in order to solicit their feedback on what would be more helpful for them as they proceeded through the process. While I did not make major revisions to this section in the main revision stage, I anticipated making more significant revisions in the operational revisions stage.

Another theme that surfaced was the participants' opinions about specific sections of the handbook; specifically the following sections: About the Author, How to Determine Focal Students, Tools and Resources, and Continuing the Work. While the majority of the feedback regarding the About the Author section was positive, one 
participant stated, "I would like to see you expand more on the reasons why you felt the students at Cole were not being successful. You touch on looking at bias, but what about instructional practice?" While I understand where she is coming from-a place of wanting to ensure teachers are using instructional practices that are successful in reaching all students - I did not think adding a discussion about instructional practices to the About the Author section made the most sense. Instead, I chose to add an entirely new section to the handbook: Equitable Teaching Strategies, which included eight highly affective teaching practices educators can use to ensure equitable teaching is occurring in their classrooms (more strategies would be added following the main field test).

In addition to adding a section regarding equitable teaching practices, I made several revisions to the Tools for Identifying Focal Students section. First, I agreed with the participant who suggested changing the section title to Tools for Determining Focal Students. The revised title is straight forward, and the language is clearer than the original section title. All the preliminary field test participants spoke favorably of the tools in the above section stating, "I like this!" or, "These tools are so clear." One revision I made to the tools section was to create an electronic version of the tools, so teachers could download them and electronically fill out the forms. Table 12 summarizes the revisions made to the preliminary form of the product.

While Table 12 summarizes the data collected regarding particular sections of the handbook, two other themes emerged that were not related to sections of the handbook, but rather were logistical categories: language use and possible additions to the handbook. There were two words that recurred in the participants' comments: the use of 
Table 12

Preliminary Field Test Formative Codes, Data, and Actions Taken in Regard to Particular Sections of Keeping Equity in Mind

\begin{tabular}{|c|c|c|}
\hline Data Code & Data Gathered from Preliminary Field Test & Action Taken \\
\hline $\begin{array}{l}\text { Senate Bill } \\
290 \\
\text { (Hungerford } \\
\text { \& Dickson, } \\
\text { 2012) }\end{array}$ & $\begin{array}{l}\text { "This is a great tool for teachers. You may want } \\
\text { to consider how it aligns with the new evaluation } \\
\text { system, SB290." } \\
\text { Regarding the list of questions to ask while } \\
\text { designing a cycle of inquiry and collecting and } \\
\text { analyzing data on page } 35-36 \text { of the preliminary } \\
\text { form of the product: "This ties into the new } \\
\text { evaluation system and student growth goals." }\end{array}$ & $\begin{array}{l}\text { Added section, How does a Cycle of } \\
\text { Inquiry Support My Work with the } \\
\text { Common Core Student Learning and } \\
\text { Growth Goals? } \\
\text { Planned to discuss goal setting and } \\
\text { SB290 in more detail with main field } \\
\text { test participants in order to ascertain } \\
\text { how I might revise the product to } \\
\text { better connect to the student learning } \\
\text { and growth goals set earlier in the } \\
\text { year. }\end{array}$ \\
\hline $\begin{array}{l}\text { About the } \\
\text { Author }\end{array}$ & $\begin{array}{l}\text { "Sets the stage well for your project--provides } \\
\text { purpose and a sense of urgency." } \\
\text { "I would like to see you expand more on the } \\
\text { reasons why you felt the students at Cole were } \\
\text { not being successful. You touch on looking at } \\
\text { bias, but what about instructional practice?" } \\
\text { "I like this part [when I explain teachers at Cole } \\
\text { were blaming students' circumstances for why } \\
\text { they were not meeting standard] because many } \\
\text { teachers can relate." } \\
\text { "Powerful statement about you, your beliefs } \\
\text { about student success and the importance of the } \\
\text { work. Well done." }\end{array}$ & $\begin{array}{l}\text { Added section in handbook regarding } \\
\text { equitable teaching strategies. }\end{array}$ \\
\hline $\begin{array}{l}\text { Focal } \\
\text { Students }\end{array}$ & $\begin{array}{l}\text { "Possibly change heading to How are Focal } \\
\text { Students Determined." } \\
\text { Regarding the paragraph before color zone } \\
\text { graphic on page } 17 \text { of preliminary handbook: } \\
\text { "This is exceedingly clear. Would it make more } \\
\text { sense to include this on page } 10 \text { where you } \\
\text { originally defined the levels or maybe a bit of } \\
\text { it?" }\end{array}$ & $\begin{array}{l}\text { Changed heading to How are Focal } \\
\text { Students Determined. } \\
\text { Decided to keep graphic and its } \\
\text { description in the original place ... it } \\
\text { did not flow well on page } 10 \text { as } \\
\text { suggested. }\end{array}$ \\
\hline Tools & $\begin{array}{l}\text { Regarding tool for determining focal students: } \\
\text { "I love this form! Actually, I like all the forms. } \\
\text { User friendly and clean. Can we get them } \\
\text { electronically?" } \\
\text { "This is helpful for teachers. I like how you } \\
\text { provided a model. Can I do it on my computer?" }\end{array}$ & $\begin{array}{l}\text { Kept forms in their original state and } \\
\text { made electronic versions available } \\
\text { for ease of use. }\end{array}$ \\
\hline $\begin{array}{l}\text { Continuing } \\
\text { Work } \\
\text { Section }\end{array}$ & $\begin{array}{l}\text { "I love this!" regarding the phrase: we are faced } \\
\text { with the exciting possibility of reshaping the } \\
\text { educational experiences for students who have } \\
\text { been historically overlooked. } \\
\text { "Ah ... I am inspired." }\end{array}$ & Kept section as is. \\
\hline
\end{tabular}


Adequate Yearly Progress (AYP) and subgroup. Participants stated comments such as, "What is AYP?" "Have you appropriately defined AYP?" and, "Do we still say AYP?" in relation to the use of AYP in the Focal Students section. Clearly, AYP is no longer an appropriate term following the passing of SB290; therefore, I changed it to mirror the language used in the common learning and growth goals associated with SB290 (Hungerford \& Dickson, 2012). In the section, Using AYP Data (to identify focal students), I changed the language to state, Using State Assessment Data.

In addition to AYP, one participant stated that the use of the word subgroup throughout the document might be offensive to some readers. Upon further examination, I agree the word subgroup has a negative connotation, and therefore, should be omitted from the handbook. Rather than referring to group membership by subgroup, I revised the preliminary form of the handbook to use the phrase group membership.

In addition to language revisions, many of the participants had ideas about what should be added to the handbook. Not surprisingly, many of them asked for specific strategies for teaching equitably and building strong relationships with their students. Initially, when drafting the preliminary form of the handbook, I purposely left these concepts out; I assumed teachers would have resources on these topics and would not need more information regarding specific strategies. Additionally, I wanted to keep the handbook readable and focused on selecting focal students and implementing a cycle of inquiry, so I worried adding sections on strategies would muddy the waters. However, after analyzing the preliminary data, it is clear the participants feel this would be a valuable addition to the handbook. Therefore, I added two entirely new sections: 
Strategies for Building Relationships with Your Focal Students and Equitable Teaching

Strategies. The following table summarizes the preliminary field test codes, data, and

actions taken in regard to language use and possible additions to the handbook.

Table 13

Preliminary Field Test Formative Codes, Data, and Actions Taken in Regard to Language Use, and Possible Additions

\begin{tabular}{|c|c|c|}
\hline Code & Data Gathered from Preliminary Field Test & Actions Taken \\
\hline Language & $\begin{array}{l}\text { Regarding the use of the word subgroup: } \\
\text { "Some people might take offense to this." } \\
\text { Regarding the use of AYP: "Is this still } \\
\text { relevant considering the revision of No Child } \\
\text { Left Behind?" } \\
\text { "Maybe call it State Assessment rather than } \\
\text { AYP?" }\end{array}$ & $\begin{array}{l}\text { Changed subgroup to group membership } \\
\text { throughout the handbook. } \\
\text { Where appropriate, changed AYP to State } \\
\text { Assessment Data. In other places, } \\
\text { changed the language to mirror that of the } \\
\text { student learning and growth goals set } \\
\text { forth by SB290 (Hungerford \& Dickson, } \\
\text { 2012) }\end{array}$ \\
\hline $\begin{array}{l}\text { Possible } \\
\text { Additions }\end{array}$ & $\begin{array}{l}\text { "Great job! This is important work, and the } \\
\text { tool makes sense! Personally, I could use } \\
\text { help learning strategies to help close the } \\
\text { achievement gap-could you give examples } \\
\text { of things teachers might do, or is that too } \\
\text { different from the specific focus of this } \\
\text { handbook?" } \\
\text { "How do teachers determine how to better } \\
\text { engage the focal group-GLAD, general } \\
\text { engagement strategies, small group } \\
\text { instruction- targeted groups?" } \\
\text { "I would like to see more ways suggested to } \\
\text { get to know your students and their } \\
\text { individual stories: have lunch with each one } \\
\text { (TALK); parent conferences, observe } \\
\text { students in and out of the classroom; home } \\
\text { visits; etc." }\end{array}$ & $\begin{array}{l}\text { Added section titled, Equitable Teaching } \\
\text { Practices, to give specific teaching } \\
\text { strategies such as: } \\
\text { - Ask high-order questions of all } \\
\text { students } \\
\text { - Think/Pair/Share } \\
\text { - Promote Interpersonal Discussion } \\
\text { Added section titled, Strategies for } \\
\text { Building Relationships with Your Focal } \\
\text { Students. The following is a sample of the } \\
\text { strategies included: } \\
\text { - Make a positive phone call home } \\
\text { - Interview your students } \\
\text { - Attend extracurricular activities } \\
\text { - Leave a note for your student }\end{array}$ \\
\hline
\end{tabular}

In addition to the data gathered in the preliminary field test, I gathered additional data while defending my dissertation proposal. My dissertation committee felt adding additional resources (i.e., websites, book titles, videos, etc.) to sections of the handbook would be useful. Therefore, I added Further Resources to the sections Strategies for 
Building Relationships with Your Focal Students and Equitable Teaching Strategies. Another revision I made to the preliminary form of the product based on my dissertation proposal defense was adding a section titled, Author's Note, which discusses why the handbook specifically focuses on racial equity (see chapter 5 for ideas on how this handbook could be adapted to meet the needs of teachers attempting to teach in ways that promote gender equity, language equity, and meet the needs of varying groups of students in their classrooms). Following the preliminary field test and main product revisions, I was ready for step six of the R\&D process: main field testing.

\section{Step 6: Main Field Testing}

The main field test "involves implementation of the new product and collection of data concerning its application. It is at this stage that the researcher collects the key 'data' concerning the new product's efficacy" (Bridges \& Hallinger, 1995, p. 122). In this stage of the development process, the researcher collects two types of data: (a) formative data, which will be used to revise and improve the product; and (b) summative data, which will serve to determine the overall efficacy of the product. In order to gather both summative and formative data, six teachers agreed to implement Keeping Equity in Mind. Table 14 summarizes the activities completed by the participants in the main field test.

Six teachers from Middleton School District participated in the main field test. The sample included three fifth-grade teachers, a secondary math and language arts teacher, a secondary math teacher, and a secondary art and civics teacher. Table 15 illustrates the main field test participants' demographics. 
Table 14

Main Field Test Data Collection Strategies

\begin{tabular}{|c|c|l|}
\hline $\begin{array}{c}\text { Data Collection } \\
\text { Strategy }\end{array}$ & $\begin{array}{c}\text { Participants Participating in Data } \\
\text { Collection Strategy }\end{array}$ & \multicolumn{1}{|c|}{ Purpose of Data Collection Strategy } \\
\hline Equity Interview & \multicolumn{1}{|c|}{ All } & $\begin{array}{l}\text { Gather baseline data regarding how } \\
\text { efficacious participants felt regarding } \\
\text { teaching their students of color following } \\
\text { their participation in formal equity training }\end{array}$ \\
\hline $\begin{array}{c}\text { Planning Meeting } \\
\text { Observation }\end{array}$ & $\begin{array}{l}\text { All } \\
\text { wehnson Elementary participants } \\
\text { planning meetings } \\
\text { Sunset High School participants } \\
\text { were observed during one } \\
\text { planning meeting }\end{array}$ & $\begin{array}{l}\text { Determine if teachers' planning was } \\
\text { changed as a result of implementing } \\
\text { Keeping Equity in Mind }\end{array}$ \\
\hline Final Interview & All & $\begin{array}{l}\text { Determine how useful the handbook was to } \\
\text { participants }\end{array}$ \\
\hline Final Survey & $\begin{array}{l}\text { Determine how useful individual sections of } \\
\text { the handbook were to participants }\end{array}$ \\
\hline
\end{tabular}

Table 15

Main Field Test Participant Demographics

\begin{tabular}{|c|c|c|c|c|c|c|}
\hline & Kate & Audrey & Jessa & Vincent & Seema & Ella \\
\hline Gender & Female & Female & Female & Male & Female & Female \\
\hline Race & White & White & White & White & $\begin{array}{c}\text { Asian Indian- } \\
\text { American }\end{array}$ & White \\
\hline $\begin{array}{c}\text { Elementary or } \\
\text { Secondary }\end{array}$ & Elementary & Elementary & Elementary & Secondary & Secondary & Secondary \\
\hline $\begin{array}{c}\text { Grade/ Subject } \\
\text { Teaching } \\
\text { Currently }\end{array}$ & $5^{\text {th }}$ Grade & $5^{\text {th }}$ Grade & $5^{\text {th }}$ Grade & $\begin{array}{c}\text { Math } \& \\
\text { English }\end{array}$ & Math & $\begin{array}{c}\text { Art \& } \\
\text { Civics }\end{array}$ \\
\hline $\begin{array}{c}\text { Number of } \\
\text { Years } \\
\text { Teaching }\end{array}$ & 20 years & 17 years & 11 years & 1 year & 13 years & 9 years \\
\hline
\end{tabular}

The main field test sample is a purposive sample (Creswell, 2007) who were selected because they had participated in equity training and were not currently enrolled 
in follow up training. All of the participants expressed feeling various levels of transformation (Mezirow, 2000) as a result of having participated in equity training and all participants expressed frustration with the lack of follow up support. Before implementing Keeping Equity in Mind, and in order to get a sense of how confident the participants in the main field test felt teaching students of color, I conducted an initial equity interview (Appendix B). The purpose of the equity interview was not to gather data regarding the usefulness of the product, but rather to get a sense of how the participants were feeling following their participation in equity training.

Equity interview. I interviewed five of the participants in their classrooms, and one participant preferred meeting at the local coffee shop. All interviews were audiotaped and transcribed. In addition to transcriptions, I took notes while the participants answered the interview questions. During the initial equity interview two themes began to emerge: following their participation in equity training, all of the participants experienced some level of transformation; however, they did not feel efficacious about teaching their students of color, and the participants hoped to gain specific strategies for working with their students of color from participating in this study.

When asked the question, How (if at all) has equity training changed the way you look at yourself as a racial individual, one participant responded, "I understand that as a White woman, I have particular privileges that are afforded me merely because of my race. I think about that a lot now." Additionally one participant reported, "I understand the challenges I face being female, but the fact that I am White ... I'm certain has helped me in ways I don't even realize. It's kind of strange." Finally, Ella mentions how she 
"feel[s] ignorant that [she] did not know the history of racism in Oregon so thoroughly until this training. That segment opened [her] eyes to the extent of injustice people of color have faced in this state." She later told me in a planning meeting that she could not stop thinking about the statistics presented at the training regarding racial inequities in Oregon and what her role in perpetuating those inequities might have been. While the participants in this study felt changed by their participation in equity training, they wanted answers. Answers to questions such as:

- "What do [I] do to better serve the students of color in my class - both socially and academically?"

- "I wish I had more resources . . like what can I do in my classroom to start teaching more equitably?"

- "How do I gain a better understanding of my students, and how I can help them?"

- "How can I have a positive effect on my students of color?"

- "How can I better reach my students and [know] what biases I carry with me?"

- "I understand I have these biases that are informing everything I do, but I don't know what they are exactly. I know that it's happening, but I don't know how it is manifesting itself in my teaching. I don't know how to teach differently."

Based on the questions the participants were asking regarding how to better meet the academic needs of their students of color, it is not surprising that, when asked the question, Following equity training, what (if anything) has changed in your teaching practice, the participants were unable to specifically give examples of how their practice had changed. One participant stated "the equity training I attended was big and broad, but it didn't necessarily help with the nitty-gritty daily grind of staying focused on equity. I would like something to help me with that." Another participant shared, "I feel that I 
have more information that inequities do exist, but I am just not sure what to do about it." One participant bravely stated, “I don't feel confident as a teacher of students of colorperiod. I feel pretty sheltered here at Sunset High School. I would be scared shitless to teach in a school with more racial diversity."

Recall the 10-step transformative process through which adults go in order to achieve a transformation of beliefs (Mezirow \& Taylor, 2009) discussed in chapter 2. It is clear from the data collected in the equity interview that the majority of the participants in this study were supported through the first five phases of transformative learning: (a) recognizing a disorienting problem; (b) examining self; (c) assessing one's beliefs; (d) recognizing that in order to relieve the discomfort caused by the disorienting problem, one must transform their taken-for-granted frames of reference; and (e) beginning to recognize and explore new roles, relationships, and actions. However, they were not supported in entering into phase six: designing a plan of action for future activities - in the case of the participants in this study, designing a plan of action for what they could do in their classrooms to better meet the academic needs of their students of color.

Following the equity interview, it was clear there is an important educational need for a product designed to support teacher leaders as they continue equity work once formal equity training at their school sites has ended. If teacher leaders ranging in experience from 1 to 20 years of teaching leave equity training feeling "frustrated" and "abandoned," certainly the field of education could benefit from such a tool. With the equity interview complete, the participants were ready to transition into the next steps: implementing the strategies presented in Keeping Equity in Mind. 
Implementation of Keeping Equity in Mind. In the January of 2014, following

the equity interviews of the six participants, the participants prepared to implement Keeping Equity in Mind. In order to ensure all participants understood what the process was for participating in this study, I scheduled two informational meetings: one at Johnson Elementary and another at Sunset High School. I explained to the participants that, in alignment with PBL (Bridges \& Hallinger, 1995) and the R\&D cycle (Borg \& Gall, 2003), I was hoping to gain insight into how useful the handbook, Keeping Equity in Mind, is for teachers following their participation in equity training. I explained that I hoped to answer the following primary and secondary research questions:

- How useful is the handbook, Keeping Equity in Mind: A Tool for Teacher Leaders to Use While Planning Their Lessons in Order to Sustain Equity Work, in building teacher efficacy in regard to teaching their students of color?

- How useful is Keeping Equity in Mind in supporting educators in explicitly thinking of their students of color as they plan their weekly lessons?

- How useful is Keeping Equity in Mind in helping educators build stronger relationships with their students of color?

- How useful is Keeping Equity in Mind in helping teacher leaders engage students of color?

- What are the participants' perceptions of the handbook's content and usability?

- What suggestions do the educational leaders have for the improvement of this handbook?

The participants at Johnson were selected as key informants (Creswell, 2007) in the planning process, because they were able to fit in two cycles of inquiry during the duration of the study. I planned to gather baseline data regarding their planning rituals by observing a planning meeting before implementing Keeping Equity in Mind. The baseline 
data would allow me to ascertain if there was a transformation in their planning rituals once they began using the tools in Keeping Equity in Mind.

The participants at Sunset High School could only commit to one cycle of inquiry due to the ending of their teaching term. Because the participants at Sunset were faced with final exams, changing of students and taking on different teaching curriculum at the conclusion of the term, planning a second cycle of inquiry at Sunset did not fit into the timeframe of this study.

Planning meeting observations at Johnson Elementary. As part of the process of measuring the efficacy of Keeping Equity in Mind, I observed three planning meetings with the fifth grade teachers at Johnson Elementary. The observations took place on January 14, 2014, January 28, 2014, and February 18, 2014. The purpose of the planning meeting observations was to determine if, through the implementation of Keeping Equity in Mind, the manner in which the fifth grade team planned their lessons would be transformed. In addition to observing, I audiotaped the planning meetings and transcribed them in order to maintain authenticity.

At the pre-cycle planning meeting, I took on the role of observer-as-participant (Johnson \& Christensen, 2008). The participants were aware I was collecting data regarding their planning rituals, but they understood I would not participate in the planning meeting; rather, I would sit to the side and observe. At the Cycle 1 planning meeting, I made it clear I would take on the role as participant-as-observer (Johnson \& Christensen, 2008); that is, I would participate in the planning of the team's first cycle of inquiry, and finally, at the Cycle 2 planning meeting, I planned to again take on the role 
of observer-as-participant — taking a backseat and allowing the team to lead the planning meeting.

The planning meeting observation protocol (Appendix D) focused on specifically gathering data on the following topics: (a) Teaching Target/Standard, (b) Teaching Strategies, (c) Assessment, (d) Discussion Regarding Specific Students, and (e) Relationship Building Strategies. All of the above topics are necessary in planning a cycle of inquiry.

Pre-cycle planning meeting. The pre-cycle planning meeting took place on January 14, 2014. All three members of the team were present, and the meeting lasted approximately 20 minutes. Eight of those minutes were spent discussing which of their students should be selected as the Rotary Club's Youth Leadership award recipientleaving 11 minutes to plan. Prior to the pre-cycle planning meeting, the fifth grade team selected mathematics as the content area on which to plan their cycles of inquiry.

The pre-cycle planning meeting began with Kate stating, "Okay, do we want to talk about math? It will be fast." The team never determined a standard on which to focus at their pre-cycle planning meeting. Rather than stating which standard they planned to teach, they walked through a binder of worksheets. From their discussion, it became clear the team was planning for a week's worth of lessons dealing with fractions. The team discussed which worksheets to use and who would do the copying. At one point, Kate brought up the idea of a common assessment, and the team agreed it was a good idea to create one; however, the team got distracted and never returned to the topic. The team did not mention any students by name in their planning, nor did they refer to groups of 
students (i.e., SpEd [Special Education], ELD [English Language Development]. etc.). In addition, they did not discuss how to build relationships or engage specific students. The meeting ended with the following discussion:

Kate: So, do we want to go into more detail about what we are teaching each day next week, or is that enough?

Audrey: I think as long as we have enough, and I can kinda put it [the worksheets] in a stack, so I know what order to do them in . . . maybe you and I could put them in a stack.

Jessa: Yeah, because I still have to do the popcorn kernels. I still have to do the three models activity. I still have to do the two SMC lessons.

Audrey: So do I.

Jessa: I have to do the computer activity.

Audrey: We all still have all those things to do.

It was clear from the pre-cycle planning meeting the fifth grade team at Johnson focused their instructional planning on what worksheets they had readily available. They jumped between talking about teaching fractions on a number line, using fraction bars, finding equivalent fractions, using a set and/or area model to represent fractions, and using the clock model to determine fractional parts of a whole, but never settled upon a specific standard. It seemed as though Kate was making an attempt to plan common lessons for the topics they planned to do the following week when she asked, "So, do we want to go into more detail about what we are teaching each day next week, or is that enough?" However, the team did not have the common ritual of specifically planning out learning activities; and therefore, they opted to skip that step and decided to put the following week's worksheets in common stacks. 
Cycle 1 planning meeting. On January 28, 2014, I met with the fifth grade team at Johnson Elementary to plan their first cycle of inquiry. All three of the team members were present and had read the handbook, filled out the Determining Focal Students tool, determined a standard on which to focus their cycle of inquiry, and had selected three to five focal students. The meeting lasted 1 hour and 40 minutes. I explained to the team that I would be participating in the planning of their first cycle, and that I would walk them through the process. The first step was to identify a specific standard on which to focus. The team had preselected math standard 5.1.1: Develop fluency with efficient procedures for adding and subtracting fractions [with like denominators] and justify what the procedures were.

They designed 5 days of lessons ranging from 30 to 40 minutes each for math standard 5.1.1. Prior to designing the lessons they planned to teach for their cycle of inquiry, they discussed the data they had to support the need to teach math standard 5.1.1, "What data do we have to support our decisions [regarding which strategy to teach]? I am using OAKS assessment from 2012/2013 and the core standard pre-test.” All team members had, through the use of the Determining Focal Students data collection sheet, already gathered the previous year's OAKS math scores for all of their students and had administered a pre-test for the fractions unit designed by the district. With these two data points in hand, they were able to quickly identify a standard on which to focus their cycle of inquiry.

As they began planning the lessons they would teach to address math standard 5.1.1, they began discussing specifically what they planned to do for each lesson. In 
addition, they had specific conversations regarding how they might engage their focal students and how they would address language use for their ELD population. The following dialogue illustrates the thinking that went into planning one of the five lessons.

Kate: Now let's look at each of the lessons. When we introduce this concept [adding and subtracting fractions with like denominators], how are we going to do that? How are we going to get those [focal] students engaged? Are we going to do some sort of Frayer Model?

Audrey: Or a pictorial ... we can do it with candy hearts because it's Valentine's Day. We could do it where we talk about ... trying to figure out what would be realistic.

Jessa: Well, what if this ... what if it's something like this . . I don't want to make it too complicated, so Audrey talk me down, but what if you have a certain amount of kids and they each have different colors and so you've got . . . you've got fractions like how many green out of . . . or maybe there don't need to be kids at all. You just split up the candy hearts into color groups. Then, you can say, you are going to add the green candy hearts and the white candy hearts.

Audrey: Oh ... like so and so's favorite colors are pink and red or pink and purple, so she wants all of those and she will share the rest with friends. How many candy hearts does she have ... and there is the same denominator because they have to find what the set is because that's what we've been working on.

Jessa: So, if we are going to give them hearts, we would have to give them a group demonstration of how to do it.

Kate: That would be the pictorial mini-lesson, right? Audrey how do you start? Obviously, we are going to do some sort of poster. Do we type up the problem? What do we ... what do we show them?

Audrey: I usually . . . um . . . you know what, I'm going to run to my classroom and get the planning sheet. I'm going to get the pictorial planning sheet ... I just need a minute to find it [Audrey goes to her classroom and returns with the pictorial planning sheet]. In fact, what if we used one of our focal students as the person in the problem? What if we somehow brought one of them in?

Jessa: That's a cool idea.

Kate: Okay, I changed it to Dustin. And Dustin loves candy hearts . . Valentine's Day is approaching and Dustin loves candy hearts. 
Audrey: Okay, what words do we want to make sure we hit for those ELD kids?

Jessa: Well, the idea that when it says "and" you are adding them. That takes them a while to figure out.

Audrey: That's a good one. When we do this, we think about what words would keep ELD kids from accessing the language. We could say, Valentine's Day is approaching - oh, that's a word you might not know, it means coming soon. Elise loves candy hearts. Her favorite colors are pink and lavender - that really light colored purple. So they are going to sketch on the worksheet and the record would be the actual whatever 12 ths, let's say it's $3 / 12$ plus $4 / 12$ equals $7 / 12$. So when we flip our little thing down, it could say . . . Basically, it's just our . . . um . . . number sentence. So what would that be...Elise has lavender hearts. She has pink hearts and

Teri: Okay, so that's your day one. Are you going to do any sort of formative assessment on that day?

Jessa: Yeah, we should. What should we do?

Teri: Can I introduce you to a fun new formative assessment I came across . . . Three Do's and a Don't. Um . . you give them a sentence frame and you start off by giving them three things you do and one thing you don't do. So, I could say, when adding and subtracting fractions with like denominators, do add the numerators, do draw a model, and do keep the same denominator, but don't add the denominators together.

Audrey: I love it! It gets them thinking! Sounds good ... Moving on to lesson two?

The team included teaching strategies such as using a Frayer Model and Pictorial Input Chart, both Guided Language Acquisition Design (GLAD) strategies designed to deliver quality instruction in engaging ways to English Language learners. The purpose of a Frayer Model is to support students with the acquisition of new vocabulary. When using a Frayer Model, teachers create a chart that is divided into four quadrants representing the following: (a) Definition of the term in the students own words, (c) facts and characteristics of the term, (c) examples of the word, and (d) non-examples of the 
word. A Pictorial Input Chart is used to introduce new content through teachers actively drawing a visual representation of the content while labeling vocabulary. The purpose of a Pictorial Input Chart is to make vocabulary understandable to students, provide a future resource for students, and help students organize new content information. The participants also discussed using strategies such as Build, Sketch and Record, a hands-on mathematical strategy where students are asked to first build a math problem using hands-on materials, then sketch or draw what they built, and finally, record their answer. In addition, they discussed having students use individual white boards to answer practice questions. Each lesson for each day used one of these specific engagement strategies.

In addition to planning the specific teaching strategies they planned to use for each lesson, they actually sat together and designed each lesson as a team. They discussed exactly what they planned to do in their classrooms to teach each lesson, and they determined a common pre- and post-test as well as designed two common formative assessments. In addition to specifically discussing focal students and ELD students, Audrey addressed how she might engage her Gifted and Talented (TAG) student when the team decided to revisit the pictorial input during their third lesson on introducing subtracting fractions with like denominators.

When we go to lesson three ... on session three ... don't you think we could revisit that problem fairly quickly and then go into drawing subtraction problems ... this will be perfect engagement to get them moving into that because they will be familiar with it ... remember Elise and her hearts, well this time Alicia is here and she wants all of the blue ones . . . the idea is you would revisit the pictorial over and over. We are just changing the prompt to subtraction. Jace can rewrite the problem for me ... he is math TAG, and thinking of how I can engage him . . . that's higher level thinking having him come up with the new problem. (Audrey, personal interview) 
While the cycle 1 planning meeting focused primarily on teaching strategies and engagement, the cycle 2 planning meeting focused more on building relationships with focal students.

Cycle 2 planning meeting. I met with the fifth grade team at Johnson for a second cycle planning meeting on February 18, 2014. The meeting lasted approximately 25 minutes. The meeting was audiotaped and transcribed, and I took notes as the meeting progressed. The team had already planned the lessons associated with the second cycle using the Pre-Cycle Planning Sheet incorporating teaching strategies such as Think Pair Share, a strategy suggested in Keeping Equity in Mind. In addition to Think Pair Share, they designed lessons including using individual white boards, another pictorial input as well as a game where students use fraction bars to add and subtract fractions with like and unlike denominators. When I sat down at the table with the team, they asked if this meeting could focus more on how they might strengthen the relationships they have with their students. Kate shared, "We already have a sense of how to plan lessons using GLAD, etc. and we planned those lessons for the next cycle on Monday . . what I need more help with is connecting with my focal students." Jessa and Audrey agreed, so we decided to spend more time on relationship building and less time on lesson planning (which they had already done). I had originally planned to act as observer-as-participant during the final planning meeting, but it was clear the team wanted more support with building strong relationships with their students, so again, I took on the role of participant-as-observer. 
Before we started discussing strategies for building relationships with their students, I asked the participants to walk me through the lesson planning they had done using the Pre-Cycle Planning sheet the previous Monday-I wanted to verify they had, indeed, planned out the lessons for the following week. I was pleased to see they all had the planning sheet filled out, and it was clear they had planned together as the activities they had selected to deliver the content was the same on each of their sheets. To begin the discussion about building relationships, we went through the handbook and discussed the different strategies. The team had already implemented the Interview strategy, Make Your Student the Center of Attention strategy, and Jessa had used the Attend Extracurricular Activities strategy.

I went to Dominic's game ... you should have seen the look on his face. He could have died. The next day in class he was like ... hey, she came to my game. His parents were pretty stoked, too ... I guess he seemed more engaged the next day ... he made more eye contact and nodded his head more while I was teaching . . he didn't seem as tuned out. (Jessa, personal interview)

Because the team had already tried several of the strategies I had added to Keeping Equity in Mind during the main product revision stage, I decided to have the team brainstorm different ideas they have done in their classrooms over the years to build relationships with their students. Jessa recalled having given hand written notes to her students and conducting morning meetings as strategies she had found successful in promoting positive relationships with her students.

I forgot about this one ... something I've done with kids before and it just makes a world of difference is . . like I'll take an index card, fold it in half and I'll put a sticker on the front and then I'll just write a little positive note [inside] and tuck it in their desk, and they'll find it in the morning, and the other kids will be like, what's that? I want one! And they love it and they keep it! And, I do morning meetings ... I check in with my kids every day like they have a chance to say 
how they're feeling and have a chance to say what they are doing well and what they want to do better. One thing I've noticed . . . that my ELD kids who don't typically share in class will share in their morning meeting a lot, so that works. My little Bianca, she never raises her hand academically, but she participates every day in the meeting. (Jessa, personal interview)

In addition to Jessa sharing strategies she had used previously, Audrey added the following technique for building strong relationships:

Also, calling them out on a celebration. I noticed so and so did some really smart thinking on this problem. So if they don't want to share, you can still draw attention to them and give them a little boost. (Jessa, personal interview)

Kate offered yet another strategy she had used in her teaching experience:

We can't discount asking kids to help us in different ways . . . just pass out papers or take this to the office for me. It's not a back and forth, but it's a "I trust you enough to do this type of thing." (Kate, personal interview)

The team also discussed using such strategies such as Question of the Day in order to get to know their students better. "You find out fascinating things about students," when you ask them about themselves. We decided the Pre Cycle Planning form needed a place where teachers could explicitly express what relationship building strategies they planned to use during the cycle. "If I have to write it down," Audrey said, "I am more likely to do it. It keeps me accountable." Following the discussion about building relationships Kate realized they had yet to determine common formative assessments. The team settled on two formative assessments (the pre- and postassessments had already been determined), and concluded their meeting.

The data collected from the planning meetings showed a definite transformation (see Table 16) from doing minimal planning to planning that was in-depth and strategic_-planning for specific standards, specific students, and specific strategies. The 
pre-cycle planning meeting focused primarily on the use of worksheets and the order in which they would be completed. There was not a discussion regarding lesson delivery nor did they discuss specific standards to be addressed. No one presented one another with questions about how they planned to teach the particular lessons, and no one pushed one another's thinking. At the cycle 1 planning meeting, participants went through filling out the Pre Cycle Planning form, which walked them through looking at data, selecting a specific standard to teach, determining measurable goals, and designing common assessments. In addition, the participants asked questions of one another and learned from one another (i.e., Audrey's pictorial input).

Table 16

Transformation of Planning Meetings at Johnson Elementary

\begin{tabular}{|c|c|c|c|}
\hline & $\begin{array}{l}\text { Pre-Cycle Planning } \\
\text { Observation }\end{array}$ & $\begin{array}{l}\text { Cycle } 1 \text { Planning } \\
\text { Observation }\end{array}$ & $\begin{array}{l}\text { Cycle } 2 \text { Planning } \\
\text { Observation }\end{array}$ \\
\hline Date & January 14, 2014 & January 28, 2014 & February 18, 2014 \\
\hline $\begin{array}{l}\text { Length of } \\
\text { Planning } \\
\text { Meeting }\end{array}$ & 19 minutes 54 seconds & 1 hour 38 minutes & 24 minutes 5 seconds \\
\hline $\begin{array}{l}\text { Teaching } \\
\text { Target(s)/ } \\
\text { Standard(s) } \\
\text { Discussed }\end{array}$ & $\begin{array}{l}\text { Target never specifically } \\
\text { defined. Discussed } \\
\text { teaching the following } \\
\text { concepts in regard to } \\
\text { fractions: } \\
\text { - Number line model } \\
\text { - Area model } \\
\text { - Fraction Bars } \\
\text { - Equivalent Fractions } \\
\text { - Set Model } \\
\text { - Clock Fractions }\end{array}$ & $\begin{array}{l}\text { Math 5.1.1 Develop fluency } \\
\text { with efficient procedures for } \\
\text { adding and subtracting } \\
\text { fractions [with like } \\
\text { denominators] and justify } \\
\text { what the procedures were } \\
\text { [with a focus on adding and } \\
\text { subtracting fractions with } \\
\text { like denominators] }\end{array}$ & $\begin{array}{l}\text { Math 5.1.1 Develop fluency } \\
\text { with efficient procedures for } \\
\text { adding and subtracting } \\
\text { fractions [with like } \\
\text { denominators] and justify } \\
\text { what the procedures were } \\
\text { [with a focus on adding and } \\
\text { subtracting fractions with un } \\
\text { alike denominators] }\end{array}$ \\
\hline
\end{tabular}


Table 16 (continued

\begin{tabular}{|c|c|c|c|}
\hline & $\begin{array}{l}\text { Pre-Cycle Planning } \\
\text { Observation }\end{array}$ & $\begin{array}{l}\text { Cycle } 1 \text { Planning } \\
\text { Observation }\end{array}$ & $\begin{array}{l}\text { Cycle } 2 \text { Planning } \\
\text { Observation }\end{array}$ \\
\hline $\begin{array}{l}\text { Teaching } \\
\text { Strategies } \\
\text { Used in } \\
\text { Lesson } \\
\text { Planning }\end{array}$ & $\begin{array}{l}\text { Discussed using } \\
\text { particular worksheets, } \\
\text { but did not discuss how } \\
\text { they planned to deliver } \\
\text { instruction }\end{array}$ & $\begin{array}{l}\text { Designed } 5 \text { days of lessons } \\
\text { that included the following } \\
\text { strategies: } \\
\text { - Frayer Model } \\
\text { - Pictorial Input } \\
\text { - Build, Sketch, and } \\
\text { Record } \\
\text { - White Boards }\end{array}$ & $\begin{array}{l}\text { Discussed } 4 \text { days of lessons } \\
\text { already planned that } \\
\text { included the following } \\
\text { strategies: } \\
\text { - White Boards } \\
\text { - Pictorial Input } \\
\text { - Think/ Pair Share } \\
\text { - Wait Time } \\
\text { - Game }\end{array}$ \\
\hline Assessment & $\begin{array}{l}\text { Discussed idea of } \\
\text { designing a common } \\
\text { formative assessment but } \\
\text { got distracted and did not } \\
\text { actually create a } \\
\text { common assessment }\end{array}$ & $\begin{array}{l}\text { Planned a common pre-test, } \\
\text { and two common formative } \\
\text { assessments and determined } \\
\text { the common post-test }\end{array}$ & $\begin{array}{l}\text { Discussed how the } \\
\text { assessments they designed } \\
\text { for the previous cycle were } \\
\text { not rigorous enough-- } \\
\text { determined they needed to } \\
\text { write more rigorous } \\
\text { assessments } \\
\text { Planned common pre-test } \\
\text { and one common formative } \\
\text { assessment and discussed } \\
\text { using same post-test }\end{array}$ \\
\hline $\begin{array}{l}\text { Discussion } \\
\text { regarding } \\
\text { specific } \\
\text { students }\end{array}$ & N/A & $\begin{array}{l}\text { Specifically discussed } \\
\text { strategies to engage the } \\
\text { following groups of } \\
\text { students: } \\
\text { - Focal students } \\
\text { - TAG students } \\
\text { - ELD students }\end{array}$ & $\begin{array}{l}\text { Specifically discussed } \\
\text { strategies to build } \\
\text { relationships with focal } \\
\text { students }\end{array}$ \\
\hline $\begin{array}{l}\text { Relationship } \\
\text { Building } \\
\text { Strategies }\end{array}$ & N/A & $\begin{array}{l}\text { Intentionally designed } \\
\text { pictorial input to include the } \\
\text { names of two focal students }\end{array}$ & $\begin{array}{l}\text { Discussed implementing } \\
\text { any of the following } \\
\text { relationship building } \\
\text { strategies: } \\
\text { - Note writing } \\
\text { - Inviting them to lunch } \\
\text { - Explicitly telling focal } \\
\text { students that they are } \\
\text { planning lessons to } \\
\text { engage them and elicit } \\
\text { feedback from them } \\
\text { - Question of the Day } \\
\text { - Helpers } \\
\text { - Morning Meeting }\end{array}$ \\
\hline
\end{tabular}


Based on the data gathered during the observations of Johnson's three planning meetings, it can be concluded that participation in the activities in Keeping Equity in Mind support teachers in doing the following:

- Identifying a specific standard on which to focus instruction

- Planning common lessons

- Planning common assessments, both formative and summative

- Discussing specific students and their academic needs (i.e., SpEd, ELD, focal, TAG)

Later in the study, the participants at Johnson reflected on the type of planning

they did during participating in a cycle of inquiry and how it related to the type of

planning they typically do. Kate shared her thoughts regarding planning well versus just planning.

I just think planning well saves so much time in the long run, and I don't get to Friday and realize I can't go home because I have no idea what I am teaching on Monday. Sure I know what topic I'm teaching, but we haven't thought through how we plan on teaching it. When you [the grade level team] are all roughly on the same page, you can get help from one another . . . like suddenly I'm not sure if my kids are getting this . . . I can ask, "What did you do?" Um . . I think for all of those reasons and more it is important to plan with a team of teachers. (Kate, personal interview)

Kate went on to state,

Also, just the team planning ... I think it is so important. I think it makes you a better teacher to have to deal with other people's viewpoint on how to plan a lesson and what to include in a lesson and how to interpret targets . . . and what you are deciding is really important in the standards and how much time to focus on it. When you are making those decisions as a team, I think it's just ... the potential for success is so much higher than when you are making those judgments by yourself. (Kate, personal interview) 
While the purpose of this study is to determine the usefulness of Keeping Equity in Mind in supporting teacher leaders as they continue equity work in their classrooms, and not about student performance, it is difficult to understand the efficacy of the product without looking at student growth. All focal students made substantial growth in regard to math standard 5.1.1 as evidenced by assessment data collected by the fifth grade teachers at Johnson Elementary.

Table 17 summarizes the focal student pre- and post- assessment data collected during the Johnson participants' cycles of inquiry (adding and subtracting fractions with like and unlike denominators).

Table 17

Pre-and Post-Assessment Data for Focal Students at Johnson Elementary

\begin{tabular}{|c|c|c|c|c|c|}
\hline $\begin{array}{c}\text { Focal } \\
\text { Student } \\
\text { (FS) }\end{array}$ & $\begin{array}{c}\text { Pre-Test } \\
\text { Score Out of } \\
26\end{array}$ & Performance Level & $\begin{array}{c}\text { Post-Test } \\
\text { Score Out } \\
\text { of } 26\end{array}$ & Performance Level & $\begin{array}{c}\text { Growth } \\
\text { Points }\end{array}$ \\
\hline FS 1 & 5 & Limited Progress & 13 & Progressing & 8 \\
\hline FS 2 & 2 & Limited Progress & 12 & Limited Progress & 10 \\
\hline FS 3 & 5 & Limited Progress & 17 & Progressing & 12 \\
\hline FS 4 & 2 & Limited Progress & 17 & Progressing & 15 \\
\hline FS 5 & 4 & Limited Progress & 17 & Progressing & 13 \\
\hline FS 6 & 3 & Limited Progress & 22 & Meets Standard & 19 \\
\hline FS 7 & 0 & Limited Progress & 15 & Progressing & 15 \\
\hline FS 8 & 1 & Limited Progress & 22 & Meets Standard & 21 \\
\hline FS 9 & 0 & Limited Progress & 10 & Limited Progress & 10 \\
\hline FS 10 & 4 & Limited Progress & 17 & Progressing & 13 \\
\hline FS 11 & 4 & Limited Progress & 17 & Progressing & 13 \\
\hline FS 12 & 1 & Limited Progress & 17 & Progressing & 13 \\
\hline FS 13 & 3 & Limited Progress & 23 & Meets Standard & 20 \\
\hline
\end{tabular}

Note. 18-26 points scored Meets Standard. 12-17 points scored is Progressing Toward Standard, and 0-11 points scored is considered Limited Progress Toward Standard. 
While the majority of the focal students are in the Progressing Toward Standard performance level, they made an average of 14 points of growth. Eight of the 13 focal students jumped one performance level, and 3 jumped two performance levels. While two students were still in the Limited Progress Toward Standard category, they both made 10 points of growth. It is clear from the evidence presented in Table 16 that the focal students in these cycles of inquiry benefitted from the direct, purposeful instruction of their teachers. Based on the planning meeting observations at Johnson, it can be concluded that using the strategies presented in Keeping Equity in Mind support teachers in doing the following:

- Use data to identify learning target/standard,

- Design common lessons with an emphasis on engaging focal (and other) students through the use of engaging teaching strategies (i.e., GLAD strategies, hands-on activities, games designed to enrich learning, and focusing lessons on topics of interest for focal students), and

- Design common assessments, and

- Talk about how to engage and motivate specific students.

Planning meeting observations at Sunset High School. Because the participants at Sunset High School all teach different subject areas, they planned individually for their first cycle of inquiry. The meeting took approximately 1 hour and 15 minutes, and the participants and I met in the boardroom of Sunset High School. The purpose of the meeting was to share ideas for planning engaging lessons for their focal students and to walk them through the implementation of a cycle of inquiry focused on a specific standard. They came to the meeting with the Determining Focal Students data form completed and their focal students selected. In addition, they each came with a specific 
standard they planned to teach during their first cycle. While the participants began working, I circulated around the room, again in the role of participant-as-observer (Johnson \& Christensen, 2008).

In preparation for supporting the planning of their first cycle, I copied the GLAD Resource Manual for each of the participants. Both Ella and Vincent were open to discussing new teaching practices, and openly engaged in discussing different strategies with me. Because they were both starting a brand new unit of study, we discussed the possibility of the two of them using the Observation Chart strategy to introduce the topic of study for their first cycle of inquiry.

Teri: One strategy I really enjoy from this book [GLAD Resource Manual] is the Observation Chart. It is designed to introduce a new topic of study.

Vincent: What is it?

Teri: You find pictures ... preferably real photos ... of the topic you are studying ... so,

Ella, what topic are you beginning to study?

Ella: Poverty.

Teri: Okay, so you would find photographs of poverty that would spark discussion, interest, or whatever and you would put them each on a piece of chart paper; hang them up around the room and have your students circulate around the room in groups commenting on the pictures. You don't give them any information about what they are looking at. Your hope is to activate prior knowledge and get them thinking without giving it to them.

Vincent: So what do they do when they are walking around the room?

Teri: Each group has a colored marker ... different colors for each group ... and they are writing what they notice . . you know . . . like I notice this about this or I wonder why blank is happening ... make sense?

Ella: Uh-huh 
Vincent: Yeah

Teri: Oh, I forgot . . . each group writes their noticings in their color. After a few minutes, you tell the groups to rotate to the next chart. Their job is to read what the groups before them wrote, and they can comment on that, or add something new.

Vincent: That sounds pretty cool. I might give it a try. It seems like it might take a long time to set up. What are you thinking Ella?

Ella: I think that would definitely get them thinking. Normally, I just say, okay, today we are starting a unit on this topic and start talking ... this seems to make them think it through before they get all the information. I'm game. You're right though, it will take time.

Teri: The cool thing is, though, once you've printed the photographs for one topic, you have them forever ... you can use them next year and the year after, too. It's a lot of work up front, but you have it forever.

Together, Vincent and Ella began to Google search images that matched their topic of study for their cycles of inquiry. They seemed genuinely engaged, and I heard comments such as, "This is cool," "Hey, check this out," and "This one is really going to get them thinking." While Ella and Vincent began planning lessons incorporating new strategies to engage their focal students, it seemed as though Seema was uninterested in collaborating. She was going through the process of filling out the planning sheet, but she did not look at the resource book, nor did she engage me in conversation. At one point, I sat down next to her and asked if she needed any support. "No, I have this planned already. I have been teaching this for 12 years, and I have it figured out." When I asked her how she planned to engage her focal students in her lessons, she reported, "I use graphic organizers to engage my students," and she ended the conversation. She was not rude; in fact, she was polite - it was clear, however, that she was going to go about planning her lessons alone (see Field Testing Issues and Challenges section for further discussion). 
While there were not several planning meetings to compare in order to determine whether or not the participants' planning was transformed at Sunset, it was clear participants were engaging in activities they had not before (i.e., data analysis and moving away from lecture style lessons).

It's like suddenly I know that about that kid . . . and I didn't really take the time to slow down and look at that data before. Now that I know that about that kid, it's like, okay, I understand a little bit more about how they work or what they get out of school ... if they are plugged in or not plugged in. It explains their behaviors or what have you, so that was really helpful. (Vincent, personal interview)

During his final interview, Vincent commented on his perception of how the lesson he planned during his planning meeting went. From one cycle, he recognized the importance of pushing himself to try new strategies rather than using strategies he is "used to using."

Awesome. It was awesome. The observation charts went really well. It's that thing of pushing myself to try new things and making me realize the things I need to do better in my practice. So, in that regard, it was really awesome. It was so ... it was just fun for me to watch. I mean fun for me as an educator to watch what they were doing and see how it went. That was really neat. (Vincent, personal interview)

Even though I only attended one planning meeting at Sunset, it was clear two of the three participants were engaged in learning new teaching strategies designed to engage their students, and they seemed to have a renewed sense of purpose as they planned those lessons. Their energy levels were high, and their enthusiasm was noticeable. While I was not able to ask Ella about her experience implementing the lessons she planned (refer to the Issues and Challenges section), I can only speculate that if she taught the lessons with the same energy and enthusiasm with which she planned them, her experience was likely positive. 
Final interviews and final survey. Following the completion of their cycles of inquiry, I met with each participant individually in order to conduct a final interview (see Appendix $\mathrm{C}$ for final interview protocol). The purpose of the final interview was to revisit the primary and secondary research questions of this study in order to determine if Keeping Equity in Mind was a useful handbook in building teacher efficacy in regard to teaching their students of color. In addition to the final interview, I conducted a final survey. Both the final interview and the final survey served as forums for the participants to give feedback on what need to be added to or omitted from the handbook, which would help guide the operational revisions in Step 7 of the R\&D cycle.

This section discusses the data collected in both the final interviews and the final survey, and how it relates to the research questions presented in this study. It addresses the secondary research questions first, and ends with a discussion regarding the primary research question: How useful is the handbook, keeping Equity in Mind: A Tool for Teacher Leaders to Use While Planning Their Lessons in order to Sustain Equity Work, in building teacher efficacy in regard to teaching their students of color.

All of the participants spoke to the value of focusing targeted instruction on focal students as one of the main benefits of implementing Keeping Equity in Mind. They reported feeling overwhelmed when having to "worry" about their entire class, and they felt a sense of ease when they were "allowed" to just zoom in and focus on three to five focal students. In addition to feeling a sense of ease, they felt more efficacious. One participant reported, "I can do this. It doesn't feel completely defeating," in response to focusing targeted instruction on three to five focal students. In addition, they reported 
seeing higher levels of engagement from all the students in their class as a result of their

focused planning.

I think one of the main benefits is choosing who your students are going to be because then you can be much more focused in designing your lessons and much more aware of their um . . . success, so if you know who the kids are, and you plan a lesson that you think they can be successful at, and then you do the assessment and get the immediate feedback, you can then meet with them more quickly. It's just more focused teaching. That alone makes a huge difference. They need . . . kids who are on the cusp of success or a little bit below that need constant feedback. It feels manageable to do it for five kids and be really consistent with five kids. It's harder to do it when there are 30. So, if you can narrow it down to really worrying about those five, then those other seven that are also in that group creep in and you can manage it. At least that's how I'm feeling. (Audrey, personal interview)

Vincent also reported feeling a sense of ease and a higher sense of efficacy when

focusing on a small "pocket of students."

What ... I guess what I feel like really helped me was . . I get lost sometimes trying to figure out how to craft my lessons and saying, okay, these are some students who are on the bubble . . like focus on these kids because the high fliers are going to get it and roll with it, and it may help some of those other lower kids that are struggling, too. So just saying, okay, here is a small pocket of kids . . . learn about these kids and help them out ... I feel like that really helped me at least in this process to be like okay, what do I need to do differently . . . just thinking about those kids and addressing their needs. That was awesome. That was really helpful and really kind of put things in perspective. You know instead of trying to say, hey, I need to hit this one girl who has never passed a class in her life and this one girl who is you know a $110 \%$. . . you know . . . how do I challenge both? So that can stretch you thin. So trying to say, okay, let's look at these middle kids . . . let's look at the bubble kids and really focus on what their needs are. That really helped me kinda do the process but also reevaluate how to build things in the future. (Vincent, personal interview)

Kate mirrored a similar sentiment:

I guess, too...I was thinking how when you are focused on a smaller group of kids, you are more focused on their body language, and of course you are always checking everyone and looking to see who seems like they are zoning out and who is paying attention, but just kind of watching and noticing when Mateo was 
more engaged, and asking questions and excited . . . and not just Mateo out of 30 [kids], but Mateo out of 5. (Kate, personal interview)

Seema reported also feeling as though focusing on fewer students made the obstacle of reaching the students who were not meeting standard more attainable.

I think . . um . . . I feel like a lot of times when you are faced with a lot of data, it can be really difficult to think about how you are going to change anything, and when you are focusing on a small number of students, that really gives you the opportunity to do something with that small number. Just intentionally picking a certain group of students to focus on was really beneficial because in a class size of 36, people can really get lost. Picking a few students isn't as overwhelming as saying you are going to do this for every one of your students in every one of your classes. (Seema, personal interview)

Similarly, Jessa stated:

It's nice to just have a few kids to focus on. I mean, it's not that you aren't helping your whole class, but it's nice to zoom in on a few kids ... I liked doing that because then it does help you get to know them better as a learner. (Jessa, personal interview)

I can conclude that, because the participants in this study reported feeling a sense of ease when given the opportunity to focus their instructional goals on the specific needs of three to five focal students, the use of the focal student strategy presented in the handbook supports teacher leaders in taking the first steps to address equity in their classrooms. Prior to using this strategy, participants mentioned feeling as though they were overwhelmed with meeting the needs of all of their students, so they continued to teach in the manner with which they had been teaching prior to participating in equity training. However, upon selecting three to five focal students, participants felt as though they could do something to begin to close the achievement gap in their classrooms. I believe, as a result of selecting focal students, participants finally felt as though teaching equitably was manageable. It was no longer a mystery — they had a plan. 
A third, unexpected, theme regarding focal students arose. Several participants reported that those students who had been "invisible" in their classrooms were finally "seen" as a result of focal group membership. Participants no longer allowed themselves to permit students to go unnoticed or to become invisible. Because the process of selecting focal students required the participants to be aware of what was happening with their focal students, they were obligated to pull those invisible students into the spotlight. Vincent reported, "Just being mindful of making a connection with these students has really helped. I feel like before, they would very successfully hide in plain sight, and that wasn't happening anymore." Jessa, Seema, and Kate all described similar experiences.

It was just nice to focus on a few kids who may not always be focused on, because they are good little girls ... they blend in. They follow the directions. They try their hardest, and I have to spend all of my energy on those turkeys over there ... you know what I mean ... so, it was really nice to force myself to say, no ... she's my focus ... I'm going to make sure I get to her every day to help her, so it was nice to have that target that I'm going to really work on those kids and not let them slip through the cracks because they are good and quiet ... because it is so easy to overlook them. (Jessa, personal interview)

I feel like for some of my focal students who are maybe more quiet or less vocal, I was able to get to know them a little bit better and create some relationships with them. Some of them didn't have that problem of being quiet, and I got to know them better as well. There was one young man who just really is very well behaved, and he never draws attention to himself, and it just really gave me an opportunity to get to know him a little bit more. (Seema, personal interview)

I think there is something about when the students know you are going to continue to call on them, and you are not going to let them be invisible anymore ... and that also that when they don't do well that you are going to come back and say, okay ... let's go over this and let me explain this again. I think that is important. You know ... knowing that they won't be let off the hook. (Kate, personal interview)

I did not anticipate focal students who had been considered invisible by their teachers prior to implementing Keeping Equity in Mind would suddenly become visible. 
As this theme continued to emerge in the final interview data, I concluded that, as a result of implementing the strategy of identifying focal students, participants no longer allowed themselves to overlook students who were quiet and compliant. They were forced to see the students who had "hid[den] in plain sight," which resulted in participants realizing they needed to hold all their students accountable — especially those students who were traditionally overlooked.

Another finding, specific to the participants teaching at the secondary level, was focal students began to advocate for themselves through making an extra effort to work with their teachers on their own time. Both Vincent and Seema reported some of their focal students initiated conversations with them advocating for themselves as a result of the [participants' perceived] relationship they were building with them.

Making that emphasis on the personal connection with the students I was targeting has really already shown dividends, because last night, two of the three students I was focusing on were in my office late working on things with me, so I don't know ... I don't know exactly how that happened ... maybe it was just focusing on their interests and having that extra little layer of awareness, but that much at least is showing something. They came by for help. They were like, hey, I need ... I'm doing this ... I don't understand this ... um, can we do this, please. [They had] never advocated for themselves. Never asked for help. They would ask for help in class, but not outside of class like hey, let's sit down ... and it was actually really cool. They were like, all right, let's go home and leave, and I said, you know you girls have been here for 45 minutes, and they were like, 45 minutes? It didn't seem that long. It just seemed like a little bit of time. I was like, oh, well ... cool. It was nice. It was really, really nice. It was definitely one of those moments when I was like, okay, this is why I do this. (Vincent, personal interview)

Similarly, Seema reported:

I made a point of working with this student and then he made a real point of working with me, so I think that um ... when he could see I was focused on him that made him want to focus more on the class as well. (Seema, personal interview) 
Through implementing the strategy of selecting focal students, participants were surprised to see several of their focal students begin to advocate for themselves academically. Prior to implementing the handbook, participants reported their focal students did not ask for help, nor did they stay after school for extra support. Participants perceived the cause for this shift in focal student behavior was a result of the effort they had invested in getting to know their focal students. While this was an unexpected finding, I find it quite interesting that this phenomenon occurred only at the secondary level. I am curious if, with continued focus on particular students, focal students at the primary level would begin to advocate for themselves as well.

In addition to the secondary students beginning to advocate for themselves, participants at both the primary and secondary level described feeling as though building relationships with their focal students was causing several of their focal students to begin to identify themselves as more serious students. Participants reported seeing a "shift in [their] focal students' attitudes" as the cycles progressed. Audrey described how a shift occurred in one of her students, Jesus, from being the classroom's class clown to a more serious student.

Jesus is way more motivated. He has become a self-manager [a title given to students who have proven they are responsible], because he is getting his homework in because he is finally understanding math. So, he is able to do it at home and bring it in. He is seeing himself much more as a student and much more less as a goof-off. I think it's because he is getting lots of positive attention for working hard. I don't only give him lots of positive attention for getting the answer right, but I'm like, oh my gosh, you are working so hard at that . . look at your understanding. (Audrey, personal interview)

Kate reported feeling as though one of her focal students, Martin, had begun to show a level of trust with her he had not previously displayed. Kate mentioned the 
process of focusing on him had allowed her to understand more about "what made him tick" and realize his anxiety regarding his identity as a student.

I think Martin has a better sense that I really care as opposed to I want him to fit inside the box. Because I talk with him a lot . . . he does not fit inside the box and he does not ... he cannot pay attention. Even when he is compliant and he sits and he listens, he is not paying attention. But he knows ... I think he feels safer knowing that I want to help him work on that as opposed to me getting him to sit on the carpet, put his eyes in this direction, do this with your assignment. I think he gets that he's not going to be able to do it that way, and we are going to have to figure out a way for him to learn where he isn't the same as everyone else. He is a lot less anxious because he is not constantly trying to figure out what my rules are and feel like he didn't do them successfully. (Kate, personal interview)

Vincent also discussed a shift in attitude for the focal students who began to

advocate for themselves. He believed those particular focal students were beginning to

trust him more with their "academic lives," which was fostering a relationship that was

not only helpful to the focal students, but was beneficial to Vincent as well.

It's so much better now. I mean, I always felt like I had good relationships with my students, but now I feel like it's really going both ways, and I feel like they can trust me with their academic lives and talk openly about how they do things. Because even when they were here, we were talking about how they take notes . . . all those little things that help you understand where they're coming from and what they're seeing. So, I think it helped both of us . . . you know . . . both parties a whole lot just being able to have that kind of conversation. I'm going to take their feedback into account. I'm going to change things. Um, you know some of the things they said they didn't like, I'm like, okay ... I can definitely tweak my class to accommodate that, and some of the things that worked for them I can incorporate that more. (Vincent, personal interview)

As a result of participants making the effort to talk to and engage their focal students, through the use of relationship building strategies presented in Keeping Equity in Mind, participants perceived their focal students began to see themselves differently as students. 
Another theme that emerged from the data was that of time, or lack of it. When asked how realistic the process of planning and implementing a cycle of inquiry is, nearly all the participants mentioned time as a factor in seeing results. Vincent reported feeling participating in one cycle of inquiry was not long enough. He anticipated he would not see immediate gains academically, but would likely have an increase in student engagement and buy-in due to his taking the time to focus on building relationships.

When I get their results, I'm thinking, “Okay, what am I going to hope for?” I hope that it [their assessment data] is better than the last one. And then, I'm looking at it and it's just ... well, yeah ... it's been one cycle-a couple of lessons and a couple of check-ins. Am I really going to see this dramatic change in this student, and I don't think I'm going to see anything [academic growth] immediately, but I am seeing a lot more just personal buy-in to my class and to me. And they [focal students] are willing to-wanting to- have a better relationship with me, because I'm being more mindful of building that relationship and being more mindful of what they need and what they want from school and trying to accommodate them as best I can. I think the academic piece will take a bit longer. Maybe four or five cycles to actually see results. (Vincent, personal interview)

The concept of time came up when Audrey was talking about the in-depth planning her team did during their first cycle of inquiry, and how she was not sure how one could do such in-depth planning in all subject areas.

You don't realize how important focused, in-depth planning is. When you do it, you realize how important and how much better it is, and how much better of a teacher you are, if you can spend the time to focus on really focused planning. It's just so time consuming for every subject. (Audrey, personal interview)

Similarly, during Sunset High School's planning meeting, Ella stated, “Trying all these new strategies takes time ... first for locating materials, and second for figuring out how you are going to deliver the information. It isn't necessarily a bad thing . . . it's just something to consider." 
On the contrary, Kate did not feel the time it took to plan the in-depth lesson associated with a cycle of inquiry as a hindrance. Instead, she commented on the time it took to ensure one is being mindful of engaging focal students. "The hardest thing is stopping and being mindful of engaging the focal students. It's not that it takes more time, but it just takes you finding the time in the day to fit it in."

While time was certainly a challenge addressed by the participants in implementing the strategies in Keeping Equity in Mind, Audrey expressed the value of building relationships with and focusing on focal students as a valuable practice, because her efforts carried over into all subject areas. Her cycle of inquiry was focused specifically on mathematics, but she noticed differences in some of her focal students across subject areas. She reported having realized that taking the time to get to know her focal students, Jesus in particular, allowed her focal students to feel more connected to their learning throughout the school day, not just during her instruction of math.

In this cycle, yeah, we focused on math, but we were focused on getting to know those kids and building relationships with them. So, that's all subjects. Even if I'm getting to know Jesus, so I can better teach him math, he is sharing during reading, writing, and social studies in a way he hasn't before, so that's got to get him more engaged. If he feels safer because he has a better relationship with me, then that is going to cover all these other subjects, too. Yeah, it was about math, but really, it was about getting to know them. (Audrey, personal interview)

I believe this finding speaks to the value of implementing the practices presented in Keeping Equity in Mind. Educational leaders are constantly juggling time (or lack thereof) in order to meet the academic needs of their students while maintaining a rigorous pace in order to meet the academic goals set forth by grade level standards. The notion that the strategies presented in Keeping Equity in Mind may facilitate increased 
engagement and buy-in for focal students across content areas is encouraging. This finding suggests the time taken to get to know focal students and plan cycles of inquiry with them in mind is not limited to the subject area in which the cycle of inquiry is focused. Rather, the time dedicated to that particular subject area carries over into other subject areas, thus making the time investment worthwhile.

The participants in this study were given multiple opportunities to share their opinions regarding the usefulness of Keeping Equity in Mind. Through participation in interviews and completion of surveys, the participants shared the aspects of the handbook which they found most valuable as well as those they felt were not as useful to the process. In addition to gathering perception data regarding the product through interviews and surveys, I also observed the participants as they interacted with the tool, which allowed me to understand how they felt as they were in the process of implementing the strategies described in Keeping Equity in Mind.

One theme that was frequently discussed by the participants was the value of the emphasis on collecting and analyzing data while participating in a cycle of inquiry.

It's those simple things. Like, I know I should be pulling data on my students and seeing what their test scores are and seeing ... you know, before I even walk into the classroom ... where they're at, but I don't do that. That's a very simple thing that it's like, no duh, I should be doing that ... um ... so that was really cool to visualize and to see where my kids are ... it's like one of those things you know, but sometimes you know, but you don't do it enough, so this forced me to do it, and I see the power of it. I'm like, okay, got it. I get it. (Vincent, personal interview)

In addition, Audrey discussed the value of participating in a cycle of inquiry and using the data collected to drive instruction as a possible vehicle to begin to close the achievement gap in her classroom. 
The whole point of it [the cycle of inquiry] is to focus in on the kids who have an achievement gap. Focus their instruction, collect the data, change your instruction, and collect more data ... I mean that's the whole point of it, so if you are consistent with it, and you are planning meaningful lessons and providing the right interventions for those kids, and really assessing them . . . and doing something about the assessment rather than just writing it in your gradebook ... yeah, I can't imagine what else you could do to change the achievement gap. (Audrey, personal interview)

As a result of the process, several of the participants reported feeling as though

they would continue to use the strategies they learned through participating in this study, because it made their teaching better. Audrey commented on feeling changed by the process of specifically selecting focal students and how she planned to continue this practice even after the study had concluded.

I think when you go through a process like this, you don't ever . . . you're changed. You're not going to ever start the year again without asking, 'who are the kids I really need to focus on? Who are the kids that I need to get to know better, so I can better teach them?' Whether they are already successful and need to be pushed up to the next level, or they are the ones who are on the cusp of falling below, and they need to have me put a lot of extra work into them, because I think once you've had an experience like this, you replicate it . . . even if it's not in the most formal way. (Audrey, personal interview)

Similarly, Vincent discussed the ease with which the processes presented in Keeping Equity in Mind would support his work in being "an agent of social change" in his classroom. Through participating in equity training, he got the "big picture," but through implementing Keeping Equity in Mind, he got the "nitty-gritty" on how to implement equity work into his daily routine.

It's good work. We went through this equity training and that was, for me, really powerful. Seeing how that translates to my kids-I want to be doing stuff like this [processes learned in Keeping Equity in Mind] a lot more than a lot of the stuff I'm doing. This stuff is really cool, and I would like it to be a greater focus on what we do as educators and how we view education and our jobs. We are agents of social change. We are here to help all of these communities that have 
disenfranchised over the years. So, something like this [Keeping Equity in Mind] is so easy. Look at these kids, talk to them, what do they need ... it's almost a no brainer. It's that easy. (Vincent, personal interview)

Kate commented on how, through participation in this study, she felt her team had done better planning then they had done previously. She reported, "I hope we can maintain this level of planning, because it just feels so much better."

Just the team planning I think is so important. I think it makes you a better teacher ... When you are making decision[s] as a team, I think it's just the potential for success is so much higher than when you are just making the judgments yourself. (Kate, personal interview)

In addition to improved planning, Kate reported feeling as though focusing on one specific standard for their cycle of inquiry as a "very appealing" process for planning lessons, which she planned to continue.

It's small and simple, and that makes it so much easier, because the cycle is so tidy. Even that you just can look at one standard and say, "This is the one thing we are going to look at." And see how they do. That makes it really appealing ... It's pretty simple, and like I said, it is realistic. It's not cumbersome. It's not like you are having to collect extra data. You can use the data you are already using. You just pull your subject area and look at it. It's realistic. (Kate, personal interview)

In order to answer the primary research question, How useful is the handbook, Keeping Equity in Mind: A Tool for Teacher Leaders to Use While Planning Their Lessons in Order to Sustain Equity Work, in building teacher efficacy in regard to teaching students of color, I analyzed the initial and final interview data to determine if there had been a shift in the participants' perceived self-efficacy in regard to teaching students of color. Table 18 highlights the findings. 
Table 18

Teacher Perceived Self-Efficacy in Teaching Their Students of Color Prior To and After Implementing Keeping Equity in Mind

\begin{tabular}{|c|c|c|}
\hline Participant & $\begin{array}{c}\text { Perceived Efficacy Prior to Implementing } \\
\text { Keeping Equity in Mind }\end{array}$ & $\begin{array}{l}\text { Perceived Efficacy After Implementing } \\
\text { Keeping Equity in Mind }\end{array}$ \\
\hline Kate & $\begin{array}{l}\text { "I feel okay teaching diverse populations, } \\
\text { but I am aware I could be better prepared } \\
\text {. y you know ... we need more strategies." }\end{array}$ & $\begin{array}{l}\text { "It's small and simple and that makes it } \\
\text { so much easier because the cycle is so } \\
\text { tidy. Even that you can just look at one } \\
\text { standard and say this is the one thing we } \\
\text { are going to look at and see how they do } \\
\text {.. that makes it really appealing. ... for } \\
\text { a school that wanted to make a difference } \\
\text { with their students of color, I think this } \\
\text { process could make a huge difference. I } \\
\text { feel like it is something we can actually } \\
\text { put into action." }\end{array}$ \\
\hline Audrey & $\begin{array}{l}\text { "I don't know. I guess I feel okay, but I } \\
\text { wish I had more resources . . . Like what } \\
\text { can I do in my classroom to start teaching } \\
\text { more equitably?" }\end{array}$ & $\begin{array}{l}\text { "The whole point [of this process] was to } \\
\text { focus on the kids who have an academic } \\
\text { gap, focus their instruction, collect data, } \\
\text { change your instruction, collect more data } \\
\text {.. I I mean that's the whole point of it, so } \\
\text { if you are consistent with it, and you are } \\
\text { planning meaningful lessons and } \\
\text { providing the right interventions for those } \\
\text { kids and really assessing them and doing } \\
\text { something about the assessment rather } \\
\text { than just writing it in your grade book... } \\
\text { yeah, I can't imagine what else you could } \\
\text { do to change the achievement gap. This is } \\
\text { manageable." }\end{array}$ \\
\hline Jessa & $\begin{array}{l}\text { "I do not feel comfortable teaching diverse } \\
\text { groups of students. I have had some } \\
\text { training teaching students who speak other } \\
\text { languages, so I feel more confident } \\
\text { teaching those students; however, I have } \\
\text { not received training for specific strategies } \\
\text { for working with students of color, and I } \\
\text { feel I need more strategies for working } \\
\text { with students of poverty as well. I need to } \\
\text { know how to integrate equity work with all } \\
\text { of the other work that goes on in a } \\
\text { classroom in terms of varying abilities." }\end{array}$ & $\begin{array}{l}\text { "Well, I think that it is satisfying to see } \\
\text { the test results and to see all the time I've } \\
\text { been spending with these kids is paying } \\
\text { off, so it makes me feel more confident } \\
\text { and it makes me feel better that there are } \\
\text { strategies you can do to actually help } \\
\text { these kids and they are actually good for } \\
\text { all kids, so why not! So, yeah, I definitely } \\
\text { feel more confident." }\end{array}$ \\
\hline
\end{tabular}


Table 18 (continued)

\begin{tabular}{|l|l|l|}
\hline Participant & $\begin{array}{l}\text { Perceived Efficacy Prior to Implementing } \\
\text { Keeping Equity in Mind }\end{array}$ & $\begin{array}{l}\text { Perceived Efficacy After Implementing } \\
\text { Keeping Equity in Mind }\end{array}$ \\
\hline Vincent & $\begin{array}{l}\text { "One of the things I really left [equity } \\
\text { training] with was like, okay, I understand } \\
\text { I have these biases that are informing } \\
\text { everything I do, but I don't know what } \\
\text { they are exactly .. I don't know how to } \\
\text { ‥ I know that it's happening, but I don't } \\
\text { know how it is manifesting itself in my } \\
\text { teaching. I don't know how to teach } \\
\text { differently." }\end{array}$ & $\begin{array}{l}\text { "This is exactly what I needed! I just } \\
\text { want tools, and I want ways to view } \\
\text { things, and I want to get as much } \\
\text { information as possible. Anything that } \\
\text { makes my life easier, I love . . and this } \\
\text { [holding up Keeping Equity in Mind] is } \\
\text { what I want to do. I don't know it just } \\
\text { makes sense to me. I love it. I have a } \\
\text { plan." }\end{array}$ \\
\hline Seema & $\begin{array}{l}\text { "I feel confident about teaching diverse } \\
\text { populations, but I also know that I will } \\
\text { make mistakes. Creating a culture where } \\
\text { even the teacher can learn and grow is } \\
\text { key." }\end{array}$ & $\begin{array}{l}\text { "Some of the strategies were useful. I } \\
\text { don't know if I feel more confident now } \\
\text { than I did at the beginning, but I will } \\
\text { definitely continue to use some of the } \\
\text { strategies." }\end{array}$ \\
\hline $\begin{array}{l}\text { "I don't feel confident as a teacher of } \\
\text { students of color-period. I feel pretty } \\
\text { sheltered here at Sunset High School. I } \\
\text { would be scared shitless (pardon the } \\
\text { phrase, I couldn't think of a better way to } \\
\text { describe it) to teach in a school with more } \\
\text { racial diversity." }\end{array}$ & No longer participating in study. \\
\hline
\end{tabular}

Teacher efficacy was affected at different levels for the participants in this study.

Some participants, like Vincent, went from reporting, "I don't know how to teach

differently" to "This [Keeping Equity in Mind] is what I want to do . . I have a plan."

Similarly, Jessa's self-efficacy increased as a result of implementing Keeping Equity in

Mind. She initially reported, "I do not feel confident at all teaching diverse groups of

students." Following her participation in this study, she reported,

Well, I think that it is satisfying to see the test results and to see all the time I've been spending with these kids is paying off, so it makes me feel more confident and it makes me feel better that there are strategies you can do to actually help these kids and they are actually good for all kids, so why not! So, yeah, I definitely feel more confident. (Jessa, personal interview) 
While Jessa and Vincent directly stated they felt more efficacious about teaching their students of color, Audrey and Kate reported having a plan that felt manageable.

The whole point [of this process] was to focus on the kids who have an academic gap, focus their instruction, collect data, change your instruction, collect more data ... I mean that's the whole point of it, so if you are consistent with it, and you are planning meaningful lessons and providing the right interventions for those kids and really assessing them and doing something about the assessment rather than just writing it in your grade book ... yeah, I can't imagine what else you could do to change the achievement gap. This is manageable. (Audrey, personal interview)

Similarly, Kate stated that, through using Keeping Equity in Mind, she felt she "[had] a plan"; something that was missing from her practice prior to participation in this study. While Kate and Audrey did not specifically state they had an increase in confidence as a result of participating in this study, we can infer that transitioning from sentiments such as, "What can I do in my classroom to start teaching more equitably" to comments such as, "I can't imagine what else you could do to change the achievement gap. This is manageable," shows that, while Audrey did not directly state she felt more confident, because she had a manageable plan, we can infer she does. While Jessa, Vincent, Audrey and Kate all reported have increased levels of self-efficacy, Seema was not confident her confidence had increased as a result of this study, "I don't know if I feel more confident now than I did at the beginning, but I will definitely continue to use some of the strategies." Seema did not share the same sentiment as the other participants, but she valued the strategies she learned in the process.

As a result of analyzing the data collected during the final interviews, I believe Keeping Equity in Mind is a valuable tool for educational leaders attempting to close the achievement gap for students of color. Participants reported feeling as though they had a 
plan for teaching more equitably and that, as a result of using the strategies presented in the handbook, they felt as though their focal students had become more actively engaged in lessons across content areas. In addition, they reported students who had traditionally been disengaged were no longer invisible, and participants at the secondary level reported their focal students began to advocate for themselves academically. The value of using this tool was corroborated in the data collected in the final survey.

Survey of the handbook. The final survey (Appendix E) of the handbook, administered at the conclusion of the study, provided summative feedback on the perceived usefulness of the handbook, and was compiled of four major sections:

- Usefulness of each section of the handbook,

- Most Useful and/or least useful aspects of each section of the handbook, - What should be added to or omitted from each section of the handbook, and

- The likelihood of participants to continue using strategies presented in the handbook

Participants were asked to rate the usefulness of each section as least useful, not useful, useful, or most useful to them as they continue equity work. As stated previously in this chapter, usefulness is defined as practical information for teacher leaders attempting to continue equity work in their classrooms once formal equity training has ended. In addition, participants were asked if the content was fully developed with necessary details and examples. Participants were also asked to answer open-ended questions regarding their perception of the most and least useful aspects of each section. Table 19 summarizes the data collected from the final survey. 
Table 19

Summary of Data Collection from Final Survey

\begin{tabular}{|c|c|c|c|}
\hline Survey Question & $\begin{array}{l}\text { Perceived } \\
\text { Usefulness of } \\
\text { Section }\end{array}$ & $\begin{array}{l}\text { Most/Least Useful Aspects of } \\
\text { Section }\end{array}$ & $\begin{array}{l}\text { Possible Additions and/or } \\
\text { Deletions to Section }\end{array}$ \\
\hline $\begin{array}{l}\text { How useful is } \\
\text { the Author's } \\
\text { Note section? }\end{array}$ & $\begin{array}{l}80 \% \text { Useful } \\
20 \% \text { Most } \\
\text { Useful }\end{array}$ & $\begin{array}{l}\text { "This section sets up the perimeters } \\
\text { [parameters] of the study. It briefly } \\
\text { addresses other concerns of equity, } \\
\text { but moves past them to focus on } \\
\text { racial equity. Without this section, } \\
\text { an educator would be left } \\
\text { wondering, "Why choose students } \\
\text { based upon racial ethnicity?"” } \\
\text { "It was a good lead in to why we do } \\
\text { this work, and I liked that you } \\
\text { included struggles of all students, } \\
\text { not focusing on one of the many } \\
\text { ways our students identify } \\
\text { themselves." }\end{array}$ & NA \\
\hline $\begin{array}{l}\text { How useful is } \\
\text { the About the } \\
\text { Author section? }\end{array}$ & $\begin{array}{l}80 \% \text { Useful } \\
20 \% \text { Most } \\
\text { Useful }\end{array}$ & $\begin{array}{l}\text { "I think I found your story more } \\
\text { engaging when we met and talked, } \\
\text { but the detail here was nice. My } \\
\text { favorite line was at the end of the } \\
\text { sixth paragraph where you shift the } \\
\text { focus of education to providing } \\
\text { access to all students." } \\
\text { "Much like teaching and using } \\
\text { learning targets, this section helped } \\
\text { me understand what the purpose of } \\
\text { the handbook was and helped me } \\
\text { see how it could be a helpful } \\
\text { resource in planning." }\end{array}$ & NA \\
\hline $\begin{array}{l}\text { How useful is } \\
\text { the Why Does } \\
\text { Equity Work } \\
\text { Matter section? }\end{array}$ & $\begin{array}{l}60 \% \text { Useful } \\
40 \% \text { Most } \\
\text { Useful }\end{array}$ & $\begin{array}{l}\text { "I'm already trying to keep equity at } \\
\text { the forefront of my teaching, so this } \\
\text { helped reaffirm what I was doing } \\
\text { and why." } \\
\text { "I felt like the research quoted gave } \\
\text { the project purpose and created buy- } \\
\text { in for the user (me)." }\end{array}$ & $\begin{array}{l}\text { "Data specific to the } \\
\text { region in which the } \\
\text { handbook is being } \\
\text { distributed would be a } \\
\text { great addition. For } \\
\text { example, there could be a } \\
\text { specific paragraph } \\
\text { (different for each } \\
\text { edition) for each state in } \\
\text { which the handbook } \\
\text { would be used. With } \\
\text { nationwide data, I think } \\
\text { educators still feel they } \\
\text { can pass the buck." }\end{array}$ \\
\hline
\end{tabular}


Table 19 (continued)

\begin{tabular}{|c|c|c|c|}
\hline Survey Question & $\begin{array}{l}\text { Perceived } \\
\text { Usefulness of } \\
\text { Section }\end{array}$ & $\begin{array}{c}\text { Most/Least Useful Aspects of } \\
\text { Section }\end{array}$ & $\begin{array}{l}\text { Possible Additions and/or } \\
\text { Deletions to Section }\end{array}$ \\
\hline $\begin{array}{l}\text { How useful is } \\
\text { the How Does a } \\
\text { Cycle of Inquiry } \\
\text { Support My } \\
\text { Work with } \\
\text { Common Core } \\
\text { Student Learning } \\
\text { and Growth } \\
\text { Goals section? }\end{array}$ & $\begin{array}{l}60 \% \text { Useful } \\
40 \% \text { Most } \\
\text { Useful }\end{array}$ & $\begin{array}{l}\text { "This section clearly laid out how } \\
\text { this work can relate to student } \\
\text { growth goals." } \\
\text { "This is exactly what I'm looking } \\
\text { for as this was the exact type of } \\
\text { evaluation I was going through at } \\
\text { the same time. I wish I had read the } \\
\text { handbook first, as it made more } \\
\text { sense than the district goal system." }\end{array}$ & NA \\
\hline $\begin{array}{l}\text { How useful is } \\
\text { the } \\
\text { Congratulations } \\
\text { section? }\end{array}$ & $\begin{array}{l}20 \% \text { Not Useful } \\
60 \% \text { Useful } \\
20 \% \text { Most } \\
\text { Useful }\end{array}$ & $\begin{array}{l}\text { "The Cycle Process section was } \\
\text { clear, but honestly, I skimmed the } \\
\text { rest." } \\
\text { "The specific description of the } \\
\text { cycle was particularly useful, as a } \\
\text { preview of what is to come." } \\
\text { "I specifically appreciated the } \\
\text { numbered list of the process. I like } \\
\text { to know the big picture of what is } \\
\text { entailed in the overall process, and } \\
\text { this was clear, concise and felt very } \\
\text { doable." }\end{array}$ & "Cut?" \\
\hline $\begin{array}{l}\text { How useful is } \\
\text { the How Do We } \\
\text { Determine Focal } \\
\text { Students section? }\end{array}$ & $\begin{array}{l}60 \% \text { Useful } \\
40 \% \text { Most } \\
\text { Useful }\end{array}$ & $\begin{array}{l}\text { "Very intuitive, visually } \\
\text { impressive - it was the heart of the } \\
\text { guidebook in my opinion." }\end{array}$ & NA \\
\hline $\begin{array}{l}\text { How useful is } \\
\text { the Ripple Effect } \\
\text { section? }\end{array}$ & $\begin{array}{l}20 \% \text { Not Useful } \\
40 \% \text { Useful } \\
20 \% \text { Most } \\
\text { Useful }\end{array}$ & $\begin{array}{l}\text { "This put me at ease right away. I } \\
\text { liked the visual of the ripple, and I } \\
\text { like being reassured that going } \\
\text { through this process would help } \\
\text { ALL my students." }\end{array}$ & NA \\
\hline $\begin{array}{l}\text { How useful was } \\
\text { the Achievement } \\
\text { Zones section? }\end{array}$ & $\begin{array}{l}40 \% \text { Useful } \\
60 \% \text { Most } \\
\text { Useful }\end{array}$ & $\begin{array}{l}\text { "This clearly laid out the zones, and } \\
\text { I especially like the visual on page } \\
16 . " \\
\text { "I like the visual of the red, yellow, } \\
\text { green zones." } \\
\text { "Easy to follow and intuitive." }\end{array}$ & $\begin{array}{l}\text { "Any way to connect to } \\
\text { growth goals?" }\end{array}$ \\
\hline
\end{tabular}


Table 19 (continued)

\begin{tabular}{|c|c|c|c|}
\hline Survey Question & $\begin{array}{l}\text { Perceived } \\
\text { Usefulness of } \\
\text { Section }\end{array}$ & $\begin{array}{c}\text { Most/Least Useful Aspects of } \\
\text { Section }\end{array}$ & $\begin{array}{l}\text { Possible Additions and/or } \\
\text { Deletions to Section }\end{array}$ \\
\hline $\begin{array}{l}\text { How useful was } \\
\text { the Focal } \\
\text { Students section? }\end{array}$ & $\begin{array}{l}80 \% \text { Useful } \\
20 \% \text { Most } \\
\text { Useful }\end{array}$ & $\begin{array}{l}\text { "The example on page } 18 \text { was } \\
\text { especially helpful." }\end{array}$ & $\begin{array}{l}\text { "The form could be } \\
\text { altered for classroom } \\
\text { assessments when state } \\
\text { assessment data is not } \\
\text { available." } \\
\text { "Maybe offer a couple of } \\
\text { different examples." }\end{array}$ \\
\hline $\begin{array}{l}\text { How useful was } \\
\text { the Building } \\
\text { Strong } \\
\text { Relationships } \\
\text { section? }\end{array}$ & $100 \%$ Useful & $\begin{array}{l}\text { "I like the concrete examples that } \\
\text { teachers can use right away." } \\
\text { "I like the resource from Aurora } \\
\text { Public Schools. I am planning to try } \\
\text { out some of those strategies." } \\
\text { "I feel like this is a personal } \\
\text { strength of mine but it is incredibly } \\
\text { important." }\end{array}$ & $\begin{array}{l}\text { "Have teachers look at } \\
\text { kids outside of the } \\
\text { classroom. Have lunch } \\
\text { with them, take them out } \\
\text { for an extra recess, let } \\
\text { them stay in at recess and } \\
\text { chat about non-academic } \\
\text { things." } \\
\text { "Hang out with kids at } \\
\text { recess as a method of } \\
\text { connecting. Eating lunch } \\
\text { with a child can also have } \\
\text { a positive effect. A busy } \\
\text { teacher might wince at } \\
\text { giving up some free time } \\
\text { (or work time) to meet } \\
\text { with a child for a } \\
\text { lengthier time, but it is a } \\
\text { worthwhile investment." }\end{array}$ \\
\hline $\begin{array}{l}\text { How useful is } \\
\text { the Equity } \\
\text { Versus Equality } \\
\text { section? }\end{array}$ & $\begin{array}{l}80 \% \text { Useful } \\
20 \% \text { Most } \\
\text { Useful }\end{array}$ & $\begin{array}{l}\text { "This section clearly outlines the } \\
\text { differences between equity and } \\
\text { equality." } \\
\text { "A good reminder." }\end{array}$ & NA \\
\hline $\begin{array}{l}\text { How useful was } \\
\text { the Equitable } \\
\text { Teaching } \\
\text { Strategies } \\
\text { section? }\end{array}$ & $\begin{array}{l}20 \% \text { Not Useful } \\
40 \% \text { Useful } \\
40 \% \text { Most } \\
\text { Useful }\end{array}$ & $\begin{array}{l}\text { "Seems like things I've learned } \\
\text { before. I see the importance in } \\
\text { general, but I didn't really need it." } \\
\text { "I think these could be valuable } \\
\text { resources for staff development as } \\
\text { well as for individuals." } \\
\text { "I had to try one of the links several } \\
\text { times. It is hard to type in the links } \\
\text { in general. Regarding equity sticks: } \\
\text { Pretty sneaky writing a student's } \\
\text { name on more than one stick. I will } \\
\text { have to remember that." }\end{array}$ & $\begin{array}{l}\text { "What bout appointment } \\
\text { Clocks? It allows students } \\
\text { choice in partnerships, but } \\
\text { does not allow them to } \\
\text { return to one child over } \\
\text { and over again." }\end{array}$ \\
\hline
\end{tabular}


Table 19 (continued)

\begin{tabular}{|c|c|c|c|}
\hline Survey Question & $\begin{array}{l}\text { Perceived } \\
\text { Usefulness of } \\
\text { Section }\end{array}$ & $\begin{array}{l}\text { Most/Least Useful Aspects of } \\
\text { Section }\end{array}$ & $\begin{array}{l}\text { Possible Additions and/or } \\
\text { Deletions to Section }\end{array}$ \\
\hline $\begin{array}{l}\text { How useful is } \\
\text { the What is a } \\
\text { Cycle of Inquiry } \\
\text { section? }\end{array}$ & $100 \%$ Useful & "Very intuitive." & $\begin{array}{l}\text { "I would like more visuals } \\
\text { or forms." }\end{array}$ \\
\hline $\begin{array}{l}\text { How useful is } \\
\text { the Getting To } \\
\text { Know You } \\
\text { survey? }\end{array}$ & $\begin{array}{l}20 \% \text { Least } \\
\text { Useful } \\
40 \% \text { Not Useful } \\
40 \% \text { Useful }\end{array}$ & $\begin{array}{l}\text { "I've seen things like this before." } \\
\text { "I wouldn't use it." }\end{array}$ & “Cut?" \\
\hline $\begin{array}{l}\text { How useful is } \\
\text { the Getting to } \\
\text { Know Your } \\
\text { Student survey? }\end{array}$ & $\begin{array}{l}20 \% \text { Least } \\
\text { Useful } \\
60 \% \text { Not Useful } \\
20 \% \text { Useful }\end{array}$ & NA & “Cut?" \\
\hline
\end{tabular}

All of the participants found the Author's Note and About the Author sections in the handbook useful or most useful. One participant reported, "Much like teaching and using learning targets, this section helped me understand what the purpose of the handbook was and helped me see how it could be a helpful resource in planning." In both the Why Does Equity Work Matter and How Does a Cycle of Inquiry Support My Work with Common Core Student Growth and Learning Goals sections, 60\% of the participants found the sections useful, and $40 \%$ of the participants found the sections most useful. In regard to the section of the handbook addressing the common core, one participant stated, “This is exactly what I'm looking for as this was the exact type of evaluation I was going through at the same time. I wish I had read the handbook first, as it made more sense than the district goal system."

Interestingly, $60 \%$ of the participants found the Congratulations section useful, while $20 \%$ found it most useful and $20 \%$ found it not useful. It was data such as this that 
really caused me pause. I had one participant who clearly valued the inclusion of this section, rating it most useful, and another who questioned whether or not the section should be cut all together from the handbook. Ultimately, I decided to look at the data as a whole: $80 \%$ of the participants ranked it as useful or most useful, and only $20 \%$ had ranked it as not useful; therefore, I decided not to cut the section, but rather, to keep it in its original form.

In terms of the How Do We Determine Focal Students section, $40 \%$ of the participants found it most useful and $60 \%$ found this section to be useful; therefore, the section remained in the handbook. Similarly, the section on achievement zones received $40 \%$ useful responses and $60 \%$ most useful responses; however, one participant asked, is there "any way to connect to growth goals?" The data I collected in the planning meeting observations and through interviews supported the suggestion of revising this section to better mirror the common core student learning and growth goals. See Step 7:

Operational product revisions for a more in-depth discussion of the revisions made to this section.

In regard to the section that introduced the concept of the ripple effect, $40 \%$ of the participants found this discussion useful, 20\% found it most useful, and $20 \%$ found it not useful. One participant stated, "This put me at ease right away. I liked the visual of the ripple, and I like being reassured that going through this process would help ALL my students." All of the participants found the section of building relationships with their students useful, and two participants shared similar suggestions for additional strategies I might include in the handbook. One participant suggested, "Have teachers look at kids 
outside of the classroom. Have lunch with them; take them out for extra recess, let them stay in at recess and chat about non-academic things.” Another participant suggested,

Hang out with kids at recess as a method of connecting. Eating lunch with a child can also have a positive effect. A busy teacher might wince at giving up some free time (or work time) to meet with a child for a lengthier time, but it is as worthwhile investment.

Therefore, I decided to add the strategies of having lunch with or "just hanging out" with students at recess to the section on building strong relationships with students.

Eighty percent of the participants found the section on equitable teaching practices useful or most useful, while $20 \%$ found it not useful. One participant reported having trouble logging on to one of the websites suggested in the further resources section due to the long web address of the webpage. Because of this participant's struggle to $\log$ on to the site I suggested, I determined a possible implication for future development of the product would be to develop a website dedicated to the handbook, so readers could log on to the webpage and access links directly, rather than having to type in long URL addresses.

The majority of the participants found the Getting to Know You survey and the Getting to Know Your Student survey least useful or not useful (20\% least useful; 40\% not useful for the student survey and $20 \%$ least useful and $60 \%$ not useful for the parent survey). Participants reported, "I’ve seen stuff like this before," and, "I wouldn't use it," in regard to the Getting to Know You surveys. As a result of this data, I determined it made sense to delete both surveys from the handbook.

In addition to asking questions regarding the usefulness of particular sections of the handbook, the final survey asked participants which, if any, of the strategies used 
during their cycles of inquiry they planned to use in the future. Participants were given the option of answering, Definitely Not, No, Yes, or Definitely Will to questions regarding particular aspects of the implementation of Keeping Equity in Mind. Table 20 summarizes their responses.

Table 20

Participants' Likelihood to Continue Using Strategies Used in Keeping Equity in Mind

\begin{tabular}{|l|l|}
\hline \multicolumn{1}{|c|}{ Survey Question } & \multicolumn{1}{|c|}{ Participants' Responses } \\
\hline $\begin{array}{l}\text { I will continue to use a cycle of inquiry model to } \\
\text { plan my lessons. }\end{array}$ & $40 \%$ Yes; 60\% Definitely Yes \\
\hline $\begin{array}{l}\text { I will continue to focus my lessons to meet the } \\
\text { needs of my focal students. }\end{array}$ & $20 \%$ Yes; 80\% Definitely Yes \\
\hline $\begin{array}{l}\text { I will continue to use strategies from this } \\
\text { handbook to build strong relationships with my } \\
\text { students. }\end{array}$ & $40 \%$ Yes; 60\% Definitely Yes \\
\hline $\begin{array}{l}\text { I will continue to use the equitable teaching } \\
\text { strategies I used in this process. }\end{array}$ & $20 \%$ Yes; 80\% Definitely Yes \\
\hline $\begin{array}{l}\text { How useful a tool is Keeping Equity in Mind for } \\
\text { teachers dedicated to teaching equitably? }\end{array}$ & $60 \%$ Useful; 40\% Most Useful \\
\hline
\end{tabular}

The data represented in Table 20 shows the participants' likelihood to continue using strategies they used while implementing the handbook. Clearly, the participants learned strategies that they found valuable during this process, because $100 \%$ of the participants had plans to continue using a cycle of inquiry model focused on focal students while planning their lessons. In addition, $60 \%$ of the participants found the handbook useful, and $40 \%$ of the participants found the handbook most useful for teachers dedicated to teaching equitably. While I understand Keeping Equity in Mind is not the only solution to closing the achievement gap, it is clear from the participants' 
plans to continue using the strategies presented in the handbook that it is one solution educators can use as they begin equity work in their classrooms.

Summary of data collection. The data in this study was collected in order to answer the primary and secondary research questions presented earlier in this chapter. Both summative and formative data were collected in order to guide the operational revisions of the handbook and to determine the efficacy of the product. This section attempts to answer the research questions guiding this study. It begins with a discussion of the secondary questions and concludes with a discussion of the primary research questions.

\section{How useful is Keeping Equity in Mind in supporting educators in explicitly} thinking of their students of color as they plan their weekly lessons? Based on the data collected in this study, it can be concluded that Keeping Equity in Mind supports educators in explicitly thinking of their students of color as they plan their weekly lessons. Recall the planning that happened in Johnson Elementary's Cycle 1 Planning Meeting. The participants explicitly thought of their focal students as they planned the pictorial input lesson. They replaced the names of teachers with the names of focal students in the story associated with the pictorial input. While this may seem a small gesture, it is my assumption the focal students have not had this type of acknowledgement often in their educational histories. It is also important to note that the participants at Johnson not only discussed specific strategies to address their focal students, but they discussed how to better meet the needs of their English language learners and their TAG students as well. 
In addition, recall Vincent's statement regarding his plans to adjust his lesson planning after having met after school with two of his focal students, "I'm like, okay, I can definitely tweak my class to accommodate that [activities his focal students felt did not work for them] and some of the things that worked for them, I can incorporate that more." Similarly, Audrey reported having included more hands-on activities in her math instruction to specifically engage two of her "busy" focal students. "If we do Build, Sketch, Record, it will keep them busy [on the mathematical content] and engaged; rather than me just modeling it up front [direct instruction].” In addition, the amount of time focused on building relationships with the focal students supported the participants in designing lessons that would support the students' engagement and learning.

\section{How useful is Keeping Equity in Mind in helping educators build stronger}

relationships with their students of color? Based on the data collected, I have concluded this is one of the handbook's strengths. All of the participants reported feeling as though the time they spent building relationships with their students was a benefit of having participated in this study, and they believed they would reap further benefits as a result of their efforts as the school year progressed. Recall the secondary participants' surprise when their focal students began to advocate for themselves and began to make an effort to initiate conversations with their teachers. I can deduce that, had the participants not made an extra effort to get to know their focal students, the participants likely would not have seen this shift in academic behavior from their students.

Furthermore, Audrey reported having learned "so much about Jesus that [she] didn't know" prior to the implementation of Keeping Equity in Mind. Because she 
learned about his extended family through casual interview techniques presented in the handbook, she was able to

tease him about his older brother that he claims he never sees because he works graveyards. I'll say, "Hey, have you seen your invisible brother lately," and he'll laugh and shake his head. Every now and then, he'll sneak over to me now and whisper, "hey, I saw my invisible brother last night. He says, hi!" (Audrey, personal interview)

One hundred percent of the participants in this study found the Strategies for Building Strong Relationships with Your Focal Students useful, and they all reported plans to continue using the strategies (as well as others) to build relationships with their students.

\section{How useful is Keeping Equity in Mind in helping teacher leaders engage}

students of color? Answering this research question posed a bit of a challenge- - how could I measure student engagement without actually talking with the students themselves? For the purposes of this study, engagement will be measured by the students' growth in the content area focused on for their teachers' cycles of inquiry. Recall the student growth data highlighted in Table16 at Johnson Elementary. Had students not been engaged, they would certainly not have been able to show such substantial growth. It is unclear if the handbook helped teachers engage students at the secondary level. Anecdotally, both Seema and Vincent felt as though their focal students were more engaged, but they did not have data to support academic growth for their focal students (see Challenges and Issues section in chapter 5 for more detail).

What are the participants' perceptions of the handbook's content and usability?

The participants had a very positive perception of the handbook's content and usability. Vincent considered the handbook a valuable resource he could use across subject areas. 
His cycle of inquiry was in Language Arts; however, he discussed using the processes he experienced in this study to support him in his mathematics courses.

I think it's all best practices [the processes set forth in Keeping Equity in Mind]. I'd like to try using it to change the way I address the math course to better suit the same students. Because, what I've learned from this is really pushing myself and trying something different and the math piece, me teaching that, is um . . . it's new to me. I've never done it before, and it's really something that I need to improve on, so using your method [Keeping Equity in Mind] would help. It would selfishly give me those bumpers, so I can get better at that topic, so I'd like that. (Vincent, personal interview)

Similarly, Audrey reported feeling as though the practices she implemented as a result of participating in two cycles of inquiry were what "good teachers do."

I think it is all useful. I think it's what we do. It's just a more formalized way of doing it. So, we might think, okay, these are my five kids in the yellow zone in reading. We might be talking RTI or whatever, and I'm like, okay, how am I going to reach them? I'm going to do this with them, or I am going to do that with them, but I guess we [the fifth grade team] don't always like plan the lesson consistently, or we don't always use a formative assessment to make sure that it is working in a timely way. This helped keep us on track in doing it in a timely way. Um . . . so that we could readjust [our instruction] more quickly. It was nice to be able to just do this in math, but really, we need to be doing it in reading, writing, math, social studies, science, and everything else. It does help keep you . . . even if we only did it in one subject, and we switched that subject every cycle, I think it could really help. (Audrey, personal interview)

She went on to report,

I think it is how we ...good teachers do things, but this helped us formalize it. We might have been thinking about these things and had those thoughts in the back of our heads, but we might not have formally written down kids that we are really worried about and what exactly are we doing for them ... um... and really owning it as opposed to an RTI system where somebody else teaches them that thing that we think is really important for them to learn, and we get the number back, but maybe we don't necessarily know or do the relationship building part because they are somewhere else. This helps us really formalize it and own it [the growth of students]. (Audrey, personal interview) 
Finally, all the participants reported plans for continuing the use of the strategies they learned while participating in this study. I can infer from this data point, that the participants find the content appropriate for the work they do in their classrooms in order to close the achievement gap.

\section{What suggestions do the educational leaders have for the improvement of this}

handbook? See Tables 10, 11, and 21 for a summary of the revisions made to the handbook based on the suggestions of the participants in this study in both the preliminary and main field tests.

Once the data collected during this study had been analyzed in order to determine the participants' perceptions of the usefulness of Keeping Equity in Mind, I moved to Step 7 of the R\&D cycle: operational revisions.

\section{Step 7: Operational Product Revisions}

During the operational product revisions stage of the R\&D cycle, the product is revised based on the analysis of the data collected in the main field test. The data collected in this study served two purposes: (a) to highlight areas for improvement of the product, and (b) to determine the efficacy of the product (Bridges \& Hallinger, 1995). This section will describe the operational revisions made to the product as well as the data I used to support those decisions.

Revision 1: Addition of section on formative assessment strategies. During the main field test, participants were asked to specifically design and administer formative assessments. The purpose of formative assessment is to determine where a group of students is in regard to mastering a particular standard. The results of formative 
assessment should be used to drive instruction - that is, depending on how students do on the formative assessment determines what you teach the next day. The teachers at Johnson were familiar with, and already using formative assessment, in their classrooms, so when they were asked to keep record of formative assessment data during their cycle, this was something with which they were comfortable. At the conclusion of their cycles, they were able to report the data they collected throughout their cycle, and explain the decisions they made based on the assessment.

The participants at Sunset, however, had a more difficult time when it came to assessment. We discussed formative assessment during their planning meeting, but the participants choose to focus more on planning their lessons, and left the designing of formative assessments for later. When their cycle concluded, and I asked the participants about their data, both Vincent and Seema were unable to provide assessment data. Vincent mentioned he checked in with kids and anecdotally placed students in groups of varied levels of understanding, but he did not have record of those groups nor did he have any recorded data. Seema mentioned giving quizzes throughout the cycle. When I asked how they drove her instruction, it became clear the quizzes, though short, were more of a summative assessment used to add to her gradebook, rather than drive instruction.

Because both Seema and Vincent did not do formative assessments, I wondered if formative assessments are something with which teachers participating in a cycle of inquiry might need support. Therefore, I determined a valuable addition to the operational form of the handbook would be a section dedicated to providing educators with several 
formative assessment options which could be used in their classrooms in a matter of minutes.

\section{Revision \#2: Added additional strategies for building relationships with focal}

students. The participants reported feeling as though building strong relationships with their focal students had had a major impact on the students' engagement in their classrooms. While the handbook used in the main field test had several different strategies for building relationships with students, I decided to add the following strategies to the Building Strong Relationships with Your Focal Students section: (a) Write a Quick Note, (b) Hang out at Recess, (c) Make a Positive Phone Call Home, (d) Have Morning Meetings, and (e) Don’t Be Afraid to Apologize.

\section{Revision \#3: Changing the language in the Focal Students section to language} that mirrors the language of student learning and growth goals (SB290; Hungerford \& Dickson, 2012). The connection between selecting focal students and the learning and growth goals set by participants in regard to the new evaluation system prompted revisions to the Focal Students section. According to SB290 (Hungerford \& Dickson, 2012), students are ranked in one of the following categories for each standard: (a) Limited Progress Toward Standard, (b) Progressing Toward Standard, (c) Meets the Standard, and (d) Exceeds the Standard. I changed the language of color zones to performance levels, and I added a fourth category (Exceeds the Standard) to the graphic as well. I revised the Pre-Cycle Planning form to reflect the growth goals set by the participants - that is, in the Determining Measurable Goals section of the planning sheet, I revised the preliminary form of the goal from $\%$ of focal students will meet 
standard to read, Focal students will show growth of percentage points/rubric points on standard during this cycle of inquiry.

Furthermore, rather than having readers choose focal students who were within one year of meeting standard, I revised the language to reflect choosing focal students who were in either the Limited Progress Toward Standard or the Progressing Toward Standard performance levels. Because the focal students' success was not going to be based solely on whether or not they passed the state assessment, but rather whether or not they made growth, it made sense to allow readers to choose focal students from both performance levels.

Revision \#4. As a result of the data collected in the final survey (only $20 \%$ of the participants found it useful), I decided to delete the Getting to Know You survey and the Getting to Know Your Student survey from the handbook.

Revision \#5: Mindset survey. The following revision was not based on a theme that emerged from the data. However, when Jessa introduced the concept to me, I immediately thought it would make a valuable addition to the handbook. She began to talk about mindsets and how they affect the way students view their academic possibilities. Jessa discussed the difference between growth mindsets and fixed mindsets and how she felt they affected learning outcomes for students.

The idea of fixed versus growth mindsets comes out of research done by Dweck (2006) at Stanford University. When people have a fixed mindset, they believe their intelligence or talents are fixed - they are born with a particular level of talent and/or intelligence, and they cannot develop either trait. In contrast those with a growth mindset 
believe their intelligence and talent can be developed - intelligence can be built upon and expanded and talents can be honed and improved (Dweck, 2006). Jessa described how she had given her students a quiz to see where her class was in terms of fixed or growth mindsets, and she was surprised at how many of her students were operating from the belief system that their intelligence was fixed, and it could not be improved. Jessa reported, 'I couldn't believe it. Three out of five of my focal students have fixed mindsets, and I need to do something about that. If my students don't believe they can build and grow intellectually, it doesn't matter what I do." Jessa shared the materials she had used (i.e., the quiz she gave students, the directions for scoring the quiz) with her class, which she had gathered online.

I added the section, Do Your Students Believe They Can Learn, to the handbook, which included a brief description of a growth mindset as well as of a fixed mindset. I included the quiz Jessa gave to her students and the scoring guide that accompanied it. In addition, I included the website for Dweck's work and the link to the Ted Talks that initially got Jessa interested in the topic of mindsets in Further Resources added to the end of the section.

Table 21 highlights the data collected and the operational revisions made as a result of that data. 
Table 21

\section{Operational Product Revisions}

\begin{tabular}{|c|c|}
\hline Data Collected & Operational Product Revisions \\
\hline $\begin{array}{l}\text { Participants at Sunset did not use formative } \\
\text { assessment during their cycle of inquiry }\end{array}$ & $\begin{array}{l}\text { Added a section to the handbook that describes } \\
\text { different formative assessments educators can use in } \\
\text { their classrooms to gather data and drive instruction }\end{array}$ \\
\hline $\begin{array}{l}\text { The process of going through a cycle of inquiry } \\
\text { focused on the growth of focal students matched } \\
\text { up nicely with the goals the participants were } \\
\text { asked to write following the passing of Senate } \\
\text { Bill } 290 \text { (SB290; Hungerford \& Dickson, 2012). } \\
\text { "If this process had happened at a slightly } \\
\text { different moment, I might have used the same } \\
\text { data and the same group of students for that } \\
\text { [student learning and growth goals set at the } \\
\text { beginning of the year] as well. So, I think that } \\
\text { focusing on certain students - certain focal } \\
\text { groups - could definitely work alongside of } \\
\text { that." (data collected during final interview) } \\
\\
\text { "This would be a great tool for teachers. You } \\
\text { may want to consider how it aligns with the new } \\
\text { evaluation system, SB290." (data collected } \\
\text { during preliminary field test) }\end{array}$ & $\begin{array}{l}\text { Made the following changes to the Focal Students } \\
\text { section of the handbook: } \\
\text { - Added Limited Progress Toward Standard to } \\
\text { Red Zone } \\
\text { - Added Progressing Toward the Standard to } \\
\text { Yellow Zone } \\
\text { - Added Meets the Standard to Green Zone } \\
\text { - Added fourth (Blue) zone: Exceeds the Standard } \\
\text { - Updated Table } 1 \text { to match new language and } \\
\text { color schemes of the performance levels } \\
\text { - Revised discussion regarding choosing students } \\
\text { in the yellow zone to choosing students in either } \\
\text { Limited Progress Toward Standard or the } \\
\text { Progressing Toward Standard performance } \\
\text { levels. }\end{array}$ \\
\hline $\begin{array}{l}\text { In regard to specific relationship building } \\
\text { strategies participants planned to implement } \\
\text { during their cycle of inquiry: "If I have to write } \\
\text { it [the strategies she planned to use to build } \\
\text { relationships with her focal students] down, I } \\
\text { am more likely to do it. It keeps me } \\
\text { accountable." }\end{array}$ & $\begin{array}{l}\text { Added a place on the Pre-Cycle Planning form for } \\
\text { teachers to specifically plan which relationship } \\
\text { building strategies they plan to use during their cycle. }\end{array}$ \\
\hline $\begin{array}{l}\text { Brainstormed with fifth grade team at Johnson } \\
\text { regarding different relationship building } \\
\text { strategies they had used in the past. Determined } \\
\text { I needed to add more strategies to the section on } \\
\text { relationships. I added some that the fifth grade } \\
\text { team reported having had success with as well } \\
\text { as adding others. }\end{array}$ & $\begin{array}{l}\text { Added more strategies to the Strategies for Building } \\
\text { Strong Relationships with Your Focal Students } \\
\text { - Positive Phone Calls Home } \\
\text { - Leave a Note } \\
\text { - Hang Out at Recess } \\
\text { - Morning Meetings } \\
\text { - Apologize } \\
\text { Added link to Ted Talks Education } \\
\text { - Rita Pierson: Build Relationships with Your } \\
\text { Students http://video.pbs.org/video/2365006547/ }\end{array}$ \\
\hline $\begin{array}{l}\text { Jessa reported, "I couldn't believe it. Three out } \\
\text { of five of my focal students have fixed mindsets, } \\
\text { and I need to do something about that. If my } \\
\text { students don't believe they can build and grow } \\
\text { intellectually, it doesn't matter what I do." }\end{array}$ & $\begin{array}{l}\text { Added section on Growth versus Fixed Mindset } \\
\text { - Defined Fixed Mindset and Growth Mindset } \\
\text { - Included student questionnaire and instructions } \\
\text { for scoring it } \\
\text { - Added discussion on what to do with the } \\
\text { information once you have collected it } \\
\text { - Added link to Ted Talk }\end{array}$ \\
\hline
\end{tabular}




\section{Field Testing Issues and Challenges}

This study was not without its challenges. While the majority of the challenges were minor and did not affect the overall outcomes of the study, they did present obstacles, which needed to be overcome. The following section outlines the issues and challenges that arose while conducting this research study.

\section{Sample Size and Selection}

The sample for the main field test of this study was a purposive sample (Johnson \& Christensen, 2008) of teachers who had participated in equity training provided by Middleton School District. The participants at Sunset were selected because their administrator was trying to determine an effective means by which to support his teachers following the completion of formal equity training by his teachers. In addition, the teachers at Johnson were selected because I had an insider perspective and an established rapport with the fifth grade team. I hoped the relationships I had with the participants at Johnson would allow them to be candid and provide honest feedback regarding the efficacy of the product. A challenge associated with the use of a purposive sample is the ability to generalize findings (Johnson \& Christensen, 2008). While I understood going in to this study that I would not be able to generalize the findings because of the sample, it would make sense in future research to conduct a larger, longitudinal study in order to determine if any of the findings in this study could be generalized or replicated.

In addition to the challenge of using a purposive sample, the sample size presented additional unforeseen challenges. This study initially included six participants - three elementary teachers and three secondary teachers; however, mid- 
study, one of the secondary participants, Ella, withdrew from the study, because she resigned from her position. Her resignation was sudden, and I was unable to contact her once she left her position in order to conduct the final interview and survey. It was especially frustrating as a researcher, because I perceived her as one of the most passionate participants — she seemed eager and ready to learn.

\section{Insufficient Time}

In designing this study, I anticipated one to two cycles of inquiry would be sufficient for me to determine if participants were beginning to transform their practice as a result of their implementation of Keeping Equity in Mind. While I could see evidence of change in practice, I believe to truly accomplish reaching phase 10 of transformation (Mezirow, 1997), participants would need to participate in a longitudinal study of at least a year to determine if the participants' practice began to internalize the use of the strategies presented in Keeping Equity in Mind.

Time also presented a second challenge at the secondary level. The participants at Sunset were nearing the end of their academic term when they began to implement Keeping Equity in Mind. With the end of the term approaching, participants were suddenly preoccupied with final exams, grading, and the conclusion of their term. While I would have liked the secondary participants to do two cycles of inquiry, it became clear that would not be a possibility within the timeframe of this study.

\section{Fidelity to the Process}

Throughout the process of this study, I was in contact with the majority of the participants via email, telephone, and/or informal discussions at their school sites. 
However, one participant, Seema, presented a challenge in that she would not return my emails, nor would she communicate with me via telephone. She participated in all the major activities associated with participation in the study (i.e., equity interview, planning meeting, final interview, and final survey); however, my perception was she was participating in the study merely because she was a member of Sunset's first cohort of teachers who had been trained in equity, not because she was especially interested in learning from the process. At Sunset's planning meeting, it became clear she had already planned out her term prior to the study, and she did not plan to alter those plans. At the conclusion of the study, I conducted final interviews, and the majority of the interviews lasted between 45 and 60 minutes. Seema's final interview only lasted 12 minutes, which suggests she may not have implemented the practices set forth by Keeping Equity in Mind. She spoke positively about the experience during her final interview, but I'm fairly certain her participation in this study did not affect her teaching practice; although, I do believe (based on her final interview data) she used several of the strategies for building relationships with her students, which she reported as having a positive effect.

\section{Would the Product Work at the Secondary Level?}

Another issue that arose was whether or not the handbook would be useful for secondary teachers. When I wrote the handbook, I had elementary teachers identified as my primary audience; I did not anticipate using the handbook with secondary teachers. However, when the opportunity to work with a team of secondary teachers arose, I thought it would only strengthen the integrity of the study. I looked at this obstacle as an opportunity to get more insightful information from the data collection. In addition to 
wondering if the handbook was appropriate for secondary teachers, I worried I did not have the secondary experience to get buy-in from the participants.

Thankfully, the secondary participants were so eager to get support in continuing equity work, it did not seem to matter that I did not have secondary teaching experience. I was welcomed into their planning meeting, and Vincent and Ella openly expressed their gratitude for the support I was able to give them in introducing possible teaching strategies. While it is my perception that Seema did not engage fully in the entire process, I do not believe it is because I was lacking secondary teaching experience.

\section{Collecting Student Assessment Data}

Collecting student assessment data presented a final challenge during this study. The participants at Johnson collected assessment data on their focal students, which they shared with me, so I could determine whether or not participation in this study might be affecting student growth. However, the secondary teachers did not provide their assessment data — even after a reminder in person and several reminders via email. I came to the possible conclusion that they did not have the data to submit, which led me to wonder how I could support secondary teachers in assessing their students. While this presented a challenge initially in the study, it became a valuable insight into what I might add to the handbook: a section on formative assessment.

\section{Chapter Summary}

This section began with an overview of this study and reviewed the study's goals as well as the primary and secondary research questions. It discussed the activities participants participated in at each stage of the R\&D cycle (Borg \& Gall, 2003), and in 
addition, this section highlighted the themes that emerged through data analysis and the main and operational product revisions that were made to the handbook as a result of that data. Finally, this chapter concluded with a discussion regarding the issues and challenges that arose throughout the R\&D cycle. The following chapter discusses the overall conclusions and assessment of my experience conducting this study. In addition, the following section includes speculations about future research, development and use of the handbook, Keeping Equity in Mind, and it concludes with recommendations for educational leaders as they support their teachers through the process of continuing equity work in their classrooms. 


\section{CHAPTER V \\ CONCLUSIONS, SPECULATIONS, AND RECOMMENDATIONS FOR LEADERSHIP}

\section{Chapter Overview}

Nationwide, educational leaders are faced with the daunting challenge of closing the academic achievement gap for their students of color. Often, people look to education as the most direct avenue for achieving the American Dream (Ladson-Billings, 2009); however, a closer look at how the American education system has been underserving students of color suggests the American Dream is obtainable for members of the majority group, while it is kept just out of arms reach for people of color. Several factors have been identified causes for the academic gap: (a) teachers' lowered expectations for students of color, (b) teachers' lowered efficacy when it comes to teaching diverse populations of students, and (c) institutionalized forms of racism in our school systems (Diamond et al., 2004; Gay, 2000; Howard, 2006; McKenzie \& Scheurich, 2008; McLaren, 2007; Sirota \& Bailey, 2009)

While districts are taking on the challenge of training their administrators and teachers in equity, formal equity training is not enough - it is the first step on a long road to change. The handbook, Keeping Equity in Mind, is one tool administrators and teachers can use in order to begin their journey with a purpose: explicitly meeting the needs of their students of color by systematically monitoring their growth and determining next learning steps so that students do not fall through the cracks. 
This study supported six teachers in beginning their journey toward teaching more equitably. They participated in one to two cycles of inquiry in order to plan engaging lessons for their focal students. In addition, they took the time to really get to know their focal students through making authentic connections. For the purposes of this study, teachers participated in interviews, completed a survey, and allowed me to observe and participate in their planning meetings. Their participation in this study supported them in beginning the hard work of keeping equity in mind while planning learning outcomes for their students of color.

This study was designed to determine the efficacy and usefulness of the handbook, Keeping Equity in Mind, designed for administrators and teacher leaders attempting to close the achievement gap in their classrooms following their participation in formal equity training. The formative and summative data collected in this study provided the foundation for operational revisions to the handbook, which will make the product more useful to leaders in the field in the future. This chapter discusses the overall conclusions of the R\&D experience. In addition, this chapter presents speculations for future research and discusses their significance to adult learning and reformative professional development as well as the development and use of the product, Keeping Equity in Mind. Furthermore, this chapter discusses recommendations for leadership, and concludes with an assessment of my experience going through the process of developing a problem based dissertation project (Bridges \& Hallinger, 1995) and using the R\&D cycle (Borg \& Gall, 2003). 


\section{Conclusions}

Designing and field testing a product addressing the educational need of supporting educational leaders in continued equity work through the use of Borg's and Gall's (2003) R\&D cycle and Bridges' and Hallinger's (1995) PBL module allowed me to better understand what teacher leaders need in order to begin to close the achievement gap in their classrooms. The following sections focus on conclusions reached during the preliminary and main field tests of the product and the revisions made as a result of the findings.

\section{Steps 4 and 5: Preliminary Field Testing and Main Product Revision}

Once I had a preliminary form of the handbook, Keeping Equity in Mind, I was prepared to conduct a preliminary field test of the product in order to determine the main product revisions needed to improve the handbook prior to the main field test. The preliminary field test sample included five teacher leaders, two TOSAs dedicated to equity work, two administrators, and one instructional coach ranging in experience from 4 to 24 years.

The participants read the handbook in its entirety and wrote marginal notes regarding questions they had about aspects of the handbook they felt were unclear, topics they found especially interesting, and suggestions for additions and/or deletions to the handbook. The following conclusions were reached following the preliminary field test of Keeping Equity in Mind:

- The handbook needed to make a clearer connection to the student learning and growth goals put forth by SB290 (Hungerford \& Dickson, 2012).

- Participants felt a section on equitable teaching practices needed to be added during the main product revisions. 
- The handbook needed a section regarding building strong relationships with students.

- The language of subgroup may be considered offensive, so it was revised to group membership.

- The use of Adequate Yearly Progress was determined antiquated, and was changed to state assessment data.

Once the main revisions had been made to the preliminary form of the product, the handbook was ready to be main field tested in order to determine further revisions needed to be made to the product as well as evaluate the efficacy of the product in supporting teachers in continuing equity work in their classrooms. The following section highlights the conclusions reached regarding the usefulness of Keeping Equity in Mind during the main field test.

Participants using Keeping Equity in Mind planned lessons that were more indepth than those they planned without using the handbook. The data collected observing the fifth grade planning meetings at Johnson Elementary showed a progression of planning beginning with the participants spending 11 minutes planning a week's worth of math lessons primarily through deciding which worksheets to use. They did not have a clear standard determined, nor did they assessments to planning sessions focused on indepth planning of common lessons focused on a specific standard. Their planning included designing common assessments and determining specific ways in which participants could engage and motivate their focal students. The participants at Johnson began talking about students by name and making adjustments in their lesson planning for their ELL, SpEd, and TAG students as well as their focal students. 
In addition to more in-depth planning, the participants in this study found selecting three to five focal students on which to focus targeted instruction very manageable. Prior to selecting focal students, the participants stated feeling overwhelmed and unable to meet the needs of upwards of 36 students. However, when they were able to focus on a smaller number of students, they felt as though they could actually make a difference in meeting the academic needs of those students. Another benefit to selecting focal students is, at the secondary level, focal students began to advocate for themselves. For the first time, focal students were initiating discussions and taking the steps necessary to get further support from their teachers. Because of the success they had with focal students, the participants in this study reported planning to continue to use selecting focal students after the conclusion of this study.

Similarly, participants found the time they took to intentionally get to know their focal students as a valuable practice. They reported feeling as though they better understood where their students were coming from, and they could connect with their students on a more authentic level. As a result of building stronger relationships with their focal students, the participants reported feeling as though they were no longer allowing their students of color to be invisible. Instead, the participants, as a result of focusing on focal students, were forced to pull those students to the forefront and engage and motivate them.

Another conclusion from the research was participants found many of their focal students began to see themselves differently as students. Suddenly, students who were not very engaged were staying after school for extra support. Students who had traditionally 
not completed assignments were getting their work in, and focal students were participating in discussions. Participants also found their focal students were not only more engaged in their focal subject area, but they were also more engaged in other subject areas.

In addition to the above findings, the main field test provided data to support the following revisions to the handbook:

- The addition of a section dedicated to formative assessment strategies,

- The addition of additional strategies for building relationships with students,

- Changing the color zones in regard to focal students to language that mirrors SB290 (Hungerford \& Dickson, 2012).

- The deletion of the Getting To Know Your survey and the Getting to Know Your Student survey, and

- The addition of the Do Your Students Believe They Can Learn section.

\section{Speculations for Future Research, Development, and Use of the Product}

The following section discusses the speculations and findings for future use of the product as well as discuss speculations and findings from the perspective of adult learning and reformative professional development.

\section{Discussion and Speculations of Findings from an Adult Learning Perspective}

This study supports teacher leaders through the first nine phases of transformative learning (Mezirow, 1997). Formal equity training guided the participants' passage through the first five phases, and implementing Keeping Equity in Mind supported the participants through phases six, seven, eight, and nine. Recall the 10 phases of transformational learning (Mezirow, 1997): 
1. Learners are faced with a disorienting dilemma

2. Learners are encouraged to participate in self-examination in order to recognize taken-for-granted frames of reference

3. Learners engage in an assessment of their taken-for-granted frames of reference

4. Learners recognize that their discontent is a result of the process of transformation

5. Learners begin to recognize and explore new roles, relationships, and actions

6. Learners put a plan of action in place

7. Learners acquire new knowledge and strategies in order to implement their new plan of action

8. Learners implement their new plan of action

9. Learners become more competent and confident in new role

10. Learners' new frame of reference is integrated into their perspective

While the participants of this study were successful in passing through the first five phases of transformational learning during their participation in formal equity training, they reported being changed-having a better understanding of their role as racial individuals and how their race affects the way in which they engage in their daily lives. However, they reported feeling as though they did not have a plan of action for how to begin to close the achievement gap in their classrooms. It is at this point that the strategies in Keeping Equity in Mind pick up where equity training left off. Table 22 summarizes the transformational phases participants went through as a result of participating in this study. 
Table 22

Transformational Phases Participants Went Through as a Result of Implementing Keeping Equity in Mind

\begin{tabular}{|c|l|l|}
\hline & $\begin{array}{l}\text { Mezirow's Phase of } \\
\text { Transformative Learning }\end{array}$ & $\begin{array}{l}\text { How Mezirow's Final Phases of Transformative Learning } \\
\text { Relate to the Implementation of Keeping Equity in Mind }\end{array}$ \\
\hline $\begin{array}{l}\text { Learners put a plan of action in } \\
\text { place. }\end{array}$ & $\begin{array}{l}\text { As a result of participating in this study, participants were } \\
\text { supported in developing a cycle of inquiry as an action plan for } \\
\text { teaching equitably in their classrooms. They designed a set of } \\
\text { lessons to address a specific standard and engage and motivate } \\
\text { their focal students. They collected and analyzed pre- } \\
\text { assessments, formative assessments, and summative } \\
\text { assessments to determine student growth. }\end{array}$ \\
\hline 7 & $\begin{array}{l}\text { Learners acquire new knowledge } \\
\text { and strategies in order to } \\
\text { implement their new plan of } \\
\text { action. }\end{array}$ & $\begin{array}{l}\text { Participants acquired knew knowledge regarding specifically } \\
\text { identifying focal students on which to focus their instructional } \\
\text { decisions. In addition, they implemented new strategies for } \\
\text { building stronger relationships with their focal students as well } \\
\text { as implemented new teaching strategies. }\end{array}$ \\
\hline 8 & $\begin{array}{l}\text { Learners implement their new } \\
\text { plan of action. }\end{array}$ & $\begin{array}{l}\text { Participants planned and implemented one to two cycles of } \\
\text { inquiry, collected data, and planned for future actions. }\end{array}$ \\
\hline 9 & $\begin{array}{l}\text { Learners become more } \\
\text { competent and confident in new } \\
\text { role. }\end{array}$ & $\begin{array}{l}\text { Participants reported feeling more confident in teaching their } \\
\text { students of color as a result of participating in this study. }\end{array}$ \\
\hline 10 & $\begin{array}{l}\text { Learners' new frame of } \\
\text { reference is integrated into their } \\
\text { perspective. }\end{array}$ & $\begin{array}{l}\text { While participants reported plans for continuing to use the } \\
\text { strategies they learned through implementing Keeping Equity } \\
\text { in Mind, the new frame of reference [planning specifically for } \\
\text { focal students using a cycle of inquiry] is likely not integrated } \\
\text { into their perspective at this point. }\end{array}$ \\
\hline
\end{tabular}

Source: Mezirow (1997)

Based on the information gathered in this study, this product can be used in conjunction with formal equity training by districts in order to support adult learners through the process of transformational learning in regard to equity in their classrooms. In order to achieve passage through Mezirow's (1997) 10 phases of transformational learning, educators need to participate in formal equity training so that they are able to recognize and begin to transform their taken for granted frames of reference. But the work cannot stop there. Educators need to be supported in moving into the final phases of 
transformational learning: creating and implementing an action plan for closing the achievement gap in their classrooms. Keeping Equity in Mind is one tool that can be implemented in order to facilitate continued transformation. In order to reach phase 10, Learners' new frame of reference is integrated into their perspective, continued formal equity work and sustained use of the cycle of inquiry process focused on focal students is necessary - this work is not something that can be achieved in one formal training and the participation in one or two cycles of inquiry. The process of transformational learning becomes ongoing and constant as teachers hone their practice to meet the needs of their students of color. To think one has mastered the art of teaching equitably, halts the transformational process, and thus, halts the process altogether.

\section{Discussion and Speculations of Findings From a Reformative Professional Development Perspective With a Focus on Inquiry}

This study supports the use of Keeping Equity in Mind by educational leadership in order to design professional development activities that are reformative. Recall the discussion of traditional types of professional development as opposed to reform types of professional development presented in chapter 2 of this dissertation. Professional development activities that fall into the category of traditional, or knowledge-for-practice, are least likely to affect change in teachers' practice or beliefs; however, teachers participating in reform activities, or professional development activities described as knowledge-of-practice, report having transformed beliefs about achievement and how their practice influences it (Borko, 2004; Cochrane-Smith \& Lytle, 2001; Garet et al., 2001). 
The cycle of inquiry works through many of the components of transformative learning, and is categorized as a professional development activity that is considered knowledge-of-practice, and therefore, is appropriate for educators attempting to transform their beliefs regarding their students of color. As a participant in the cycle of inquiry, teachers are given the opportunity to see first-hand whether or not their practice is impacting the achievement of their students, particularly their students of color. If teachers are reflecting critically on their own practice and whether or not if affects student learning, I believe they are likely to begin to look at systems of inequity, which may be their own practice, as the cause for lowered student achievement rather than continue to blame the students themselves.

By coupling formal equity training with the use of Keeping Equity in Mind, administrators can support their staffs through continued professional development that can be reformative - a cyclical process that becomes part of the practice of those participating. Recall, Darling-Hammond and McLaughlin (1995) argued the success of the reform agenda depends on 'teachers' success in accomplishing the serious and difficult task of learning the skills and perspectives assumed by new visions of practice and unlearning the practices and beliefs about students and instruction that have dominated their professional lives" (p. 597). While formal equity training supports teachers in "learning the perspectives assumed by new visions of practice," Keeping Equity in Mind supports teachers in "learning the skills" necessary for putting new perspectives into practice. 


\section{Speculations for Future Research, Development, and Use of the Product}

In order to support teachers through the 10 phases of transformational learning (Mezirow, 1997), I believe a longitudinal study designed to determine the long-term effects of implementing the strategies presented in Keeping Equity in Mind would be beneficial in understanding if, through participation in Keeping Equity in Mind, teachers are able to move into the tenth phase of transformative learning: Learners' new frame of reference is integrated into their perspective (Mezirow, 1997), and I would argue integrated into their practice.

While participation in one or two cycles of inquiry allowed the participants to see the benefits associated with using a cycle of inquiry and the strategies presented in the handbook, the study was not long enough to determine if participants would actually transform their practice to incorporate equitable planning focused on their students of color. Vincent alluded to the possibility of the cycle of inquiry process "slowly internalizing where it's not even a process anymore; it's just how you design lessons ... it's just how you teach ... it's just built into the way you think." However, I believe it would be beneficial for administrators to support their staffs through prolonged use of Keeping Equity in Mind in order to determine if, in fact, prolonged use would transform the way in which teachers plan their lessons and think of their students of color.

In conjunction with a longitudinal study designed to identify the long-term effects of implementing Keeping Equity in Mind on transforming educators' teaching practices, I believe the development of a website dedicated to the handbook would be a useful tool. The development of a website did not fit into the parameters of this study; however, I 
recognize the value in educators being able to log into a website, which would have electronic versions of the forms, links to informational videos and websites with pertinent information regarding strategies for building relationships with students, using equitable teaching practices, and participating in a cycle of inquiry. The website could also include a chat forum for teachers in the process of using the handbook to initiate dialogues with one another regarding their experience using the handbook.

Finally, I believe future research on the applicability of the concepts presented in Keeping Equity in Mind and how they might support teacher leaders focusing on other groups of focal students would be worthwhile. It is my assumption that leaders wanting to see academic growth with their special education population, with their English language learners, or with girls in a particular subject area could design a cycle of inquiry with those focal students in mind and likely see similar results as those found in this study.

\section{Recommendations for Leadership}

Districts nationwide are increasingly focused on closing the achievement gap for their Black and Latino students. As this becomes more and more important, educators and educational leaders are being formally trained in equity are beginning to transform their beliefs about themselves as racial individuals. Although educators and educational leaders have participated in equity training, often, there is little to no follow through in supporting teachers and the administrators who support them with understanding how this new frame of reference manifests itself in the classroom. I believe Keeping Equity in Mind can serve as a tool to help educational leaders carry out the mission of ensuring the 
students in their classrooms are experiencing quality instruction that is engaging, motivating, and equitable.

Administrators are charged with the task of ensuring quality, equitable instruction is occurring in their school's classrooms. While most administrators are confident in their ability to support their teachers in improving instructional practices in their classrooms, it is my experience that fewer are confident in their ability to support their staffs in incorporating equitable teaching strategies. As districts nationwide take on the challenge of ensuring all students receive equitable learning opportunities, educational leaders (i.e., administrators, super intendants, board members, etc.) will be responsible for finding tools and resources to implement in their school sites that will support teachers in their efforts in closing the achievement gap, and Keeping Equity in Mind is one tool educational leaders can use to scaffold equitable planning for their staffs. In giving their staffs a concrete plan of action (a cycle of inquiry focused on focal students) following formal equity training, administrators can ensure equitable teaching practices are being implemented in the classrooms of their teachers immediately following formal equity training.

While educators are grappling with implementing the new evaluation system associated with SB290 (Hungerford \& Dickson, 2012) and how to successfully monitor student growth, administrators can incorporate the implementation of Keeping Equity in Mind in order to ensure their staffs are monitoring student progress, with a focus on equity, throughout the school year. In fact, the use of Keeping Equity in Mind can be written in the goals set by educators at the start of each school year and used to gather the 
appropriate data necessary in monitoring those goals. The handbook provides teachers with data collection forms and planning forms, which can support teachers in ensuring they are continually monitoring the growth of their students through the collection of formative and summative assessment.

In addition to supporting their staffs with monitoring student learning and growth goals, Keeping Equity in Mind can support administrators in helping their teachers implement instructional strategies that build relationships with and challenge their students of color. The handbook will support teachers in ensuring their students of color do not become invisible or "fall through the cracks." As equity is becoming more and more prevalent in the missions and visions of schools and school districts, implementing Keeping Equity in Mind on a school-wide basis can support educational leaders in creating a school culture where teachers use data to drive instruction, plan focused lessons with their students of color in mind, and maintain rigorous learning outcomes for all students.

While teachers are ultimately responsible for implementing the strategies introduced in Keeping Equity in Mind, administrators can benefit from setting a tone and school culture that honors equity, implementing instruction that is focused and explicit, and supporting their teachers in monitoring their students' learning and growth goals. Why leave equity training empty-handed, when you can hit the ground running with Keeping Equity in Mind? 


\section{Assessment of Experience}

I found the experience of designing a problem based project (Bridges \& Hallinger, 1995) through the use of the R\&D cycle (Borg \& Gall, 2003) very rewarding. As a teacher, I recognize problems facing educators all the time; however, it is not every day I get the opportunity to actually take the steps necessary to try to improve them. I have found the process of identifying a problem (one with which I have struggled my entire career), designing a product that educators can use to solve it, improving the product, and actually using the product in classrooms exhilarating. It is something I never imagined doing before this process - too often, teachers have a wealth of knowledge and experience that goes unshared because we become too wrapped up in our own classrooms and the growth of our students that we never get around to sharing that great idea we had with others. Through this process, I was forced to very intentionally think through my experience with equity in order to think of how I might support teacher leaders and administrators in continuing equity work in their schools and classrooms.

The process of reviewing the literature allowed me to get a more in depth understanding of how teachers' lowered expectations for their students of color actually lead to lowered teacher efficacy and lowered rigor in instruction for students of color (Gay, 2000). A review of the literature grounded my previously held frames of reference in theory and research, which allowed me to better articulate my beliefs to those around me. I found I was speaking more intelligibly with my colleagues regarding equity and student achievement. I do not believe I would have grown in terms of knowledge on the subject, if I had not gone through the process of reviewing the literature. 
Actually developing the preliminary form of the product was daunting at first, but quickly became a part of my daily routine. I was surprised to find myself coming up with a perfect way to organize a particular section on my way to get a cup of coffee, or I would be in the middle of dinner and remember a perfect quote to support the ideas I was presenting in one section or another. A day did not go by where I was not thinking about how I could improve Keeping Equity in Mind, so when it came time to do the preliminary field test, I found myself excited, but also quite nervous about how it would be received by other educators.

Once I got through the preliminary field test, I was excited to revise the handbook in order to better meet the needs of educators in Middleton School District. I enjoyed adding sections to the handbook on building relationships with students and equitable teaching practices, and I found myself very excited to begin the main field test. I could not wait to see if Keeping Equity in Mind could actually change the way teachers planned for their students of color in their classrooms.

Participating in the planning meetings at Johnson and Sunset was exciting work. It was great to see teachers debating the value of choosing one teaching strategy over the other, and it was rewarding to hear educators talking about specific students, and how they planned to engage and motivate them. I found myself missing the classroom more and more as I worked with the teachers in this study to plan equitable lessons. The implementation of Keeping Equity in Mind renewed my love of teaching and passion for ensuring all children receive equitable learning opportunities. 
Finally, going through the process of collecting and analyzing data evoked feelings of overwhelm, exhaustion, exhilaration, revelation, and complete awe at the insight the participants shared as a result of their experiences participating in this study. I never imagined I would learn so much from this process, both as a professional and a doctoral student. I truly believe I am forever changed from participating in this process. I will never look at students the same; I will honor teachers' experiences and be awe inspired by their honesty and genuine desire to make a difference; and I will never turn away a researcher again — since beginning this process, I have agreed to participate in upwards of 10 telephone surveys, and one study!

Going through this process has brought me to tears, caused me to laugh out loud at myself, and celebrate the small accomplishments that add up to one incredible experience — one which I would not trade for the world.

\section{Chapter Summary}

This chapter discussed the overall conclusions of the R\&D process following the implementation of the preliminary and main field tests. In addition, it presented speculations for future R\&D and discussed their significance to adult learning and reformative professional development. Furthermore, this chapter discussed speculations for future R\&D in the field of education. Finally, this chapter concluded with a discussion of the recommendations for leadership and an assessment of my experience going through the process of developing a problem passed project using the R\&D cycle. 


\section{REFERENCES}

Adams, M. (2000). Readings for diversity and social justice. New York, NY: London, UK: Routledge.

Adams, M., Bell, L. A., \& Griffin, P. (2007). Teaching for diversity and social justice (2nd ed.). New York, NY: Routledge.

Agar, M. (1980). The professional stranger: An informal introduction to ethnography. New York, NY: Academic Press.

Barth, P., Haycock, K., Jackson, H., Mora, K., Ruiz, P., Robinson, S., \& Wilkins, A. (1999). Dispelling the myth: high poverty schools exceeding expectations. Washington, DC: The United States Department of Education.

Bateson, M. C. (1994). Peripheral visions: Learning along the way. New York, NY: Harper Collins.

Borg, W. R., \& Gall, M. D. (2003). Educational research: An introduction (5th ed.). New York, NY: Longman.

Borko, H. (2004). Professional development and teacher learning: Mapping the terrain. Educational Researcher, 33(8), 3-15. doi:10.3102/0013189x033008003

Bridges, E. M., \& Hallinger, P. (1995). Implementing problem based learning in leadership development. Eugene, OR: University of Oregon, ERIC Clearinghouse on Educational Management.

Cochrane-Smith, M., \& Lytle, S. L. (2001). Beyond certainty: Taking an inquiry stance on practice. In A. Lieberman \& L. Miller (Eds.), Teachers caught in action: Professional development that matters (pp. 45-58). New York, NY: Teachers College Press.

Creswell, J. W. (2007). Qualitative inquiry and research design: Choosing among five approaches (2nd ed.). Thousand Oaks: Sage.

Darling-Hammond, L. (2007). Third annual "Brown" lecture in education research-The flat Earth and education: How America's commitment to equity will determine our future. Educational Researcher, 36(6), 318-334. 
Darling-Hammond, L., \& McLaughlin, M. W. (1995). Policies that support professional development in an era of reform. Phi Delta Kappan, 76(8), 597-604.

DeCuir, J. T., \& Dixson, A. D. (2004). "So when it comes out, they aren't that surprised that it is there": Using Critical Race Theory as a tool of analysis of race and racism in education. Educational Researcher, 33(5), 26-31.

doi:10.3102/0013189x033005026

Delpit, L. D. (2006). Other people's children: Cultural conflict in the classroom. New York, NY: New Press, W.W. Norton.

Derman-Sparks, L., \& Phillips, C. B. (1997). Teaching/learning anti-racism: A developmental approach. New York, NY: Teachers College Press.

Desimone, L. M., Porter, A. C., Garet, M. S., Yoon, K. S., \& Birman, B. F. (2002). Effects of professional development on teachers' instruction: Results from a threeyear longitudinal study. Educational Evaluation and Policy Analysis, 24(2), 81-112.

Diamond, J. B., Randolph, A., \& Spillane, J. P. (2004). Teachers' expectations and sense of responsibility for student learning: The importance of race, class, and organizational habitus. Anthropology and Education Quarterly, 35(1), 75-98.

Dweck, C. S. (2006). Mindset: The new psychology of success. New York, NY: Random House.

Elmore, R. (1996). Getting to scale with good educational practice. Harvard Educational Review, 66(1), 1-27.

Ernest, P. (1994). Varieties of constructivism: Their metaphors, epistemologies and pedagogical implications. Hiroshima Journal of Mathematics Education, 2, 1-14.

Falk, B. (2001). Professional learning through assessment. In A. Lieberman \& L. Miller (Eds.), Teachers caught in the action: Professional development that matters (pp. 118-140). New York, NY: Teachers College Press.

Ferguson, R. (2005, October 24-25). Toward skilled parenting and transformed schools inside a national movement for excellence with equity. Paper presented at the First Educational Equity Symposium of the Campaign for Educational Equity, Teachers College, Columbia University, New York, New York.

Garet, M. S., Porter, A. C., Desimone, L., Birman, B. F., \& Yoon, K. S. (2001). What makes professional development effective? Results from a national sample of teachers. American Educational Research Journal, 38(4), 915-945. 
Gay, G. (2000). Culturally responsive teaching: Theory, research, and practice. New York, NY: Teachers College Press.

Guba, E. G. (1990). The paradigm dialog. Newbury Park, CA: Sage.

Guba, E. G., \& Lincoln, Y. S. (1994). Competing paradigms in qualitative research. In N. K. Denzin \& Y. S. Lincoln (Eds.), Handbook of qualitative research (pp. 105117). London, UK: Sage.

Guskey, T. R. (1986). Staff development and the process of teacher change. Educational Researcher, 15(5), 5-12.

Guskey, T. R. (2002). Professional development and teacher change. Teachers and Teaching, 8(3/4), 381-391. doi:10.1080/135406002100000512

Hargreaves, A., \& Dawe, R. (1990). Paths of professional development: Contrived collegiality, collaborative culture, and the case of peer coaching. Teaching and Teacher Education, 6(3), 227-241.

Haycock, K. (1998). Good teaching matters: How well qualified teachers can close the gap. Thinking $K-16,3(2), 1-2$.

Herr, K. (1999). Private power and privileged education: De/constructing institutionalized racism. International Journal of Inclusive Education, 3(2), 111-129.

hooks, b. (1994). Teaching to transgress: Education as the practice of freedom. New York, NY: Routledge.

Howard, G. R. (2006). We can't teach what we don't know: White teachers, multiracial schools (2nd ed.). New York, NY: Teachers College Press.

Hungerford, N., \& Dickson, K. (2012). Oregon's Senate Bill 290: A primer. Portland, OR: Chalkboard Project.

Hunt, P., Soto, G., Maier, J., \& Doering, K. (2003). Collaborative teaming to support students at risk and students with severe disabilities in general education classrooms. Exceptional Children, 69(3), 315.

Johnson, B., \& Christensen, L. B. (2008). Educational research: Quantitative, qualitative, and mixed approaches (3rd ed.). Los Angeles, CA: Sage.

Katz, J. H. (2003). White awareness: Handbook for anti-racism training (2nd ed.). Norman, OK: University of Oklahoma Press. 
Kidd, J., \& Congdon, L. (2007). About focal students. (Available from Partners in School Innovation, 1060 Tennessee Street, 2nd Floor, San Francisco, CA 94107)

Kidd, J., \& Starr, M. (2011). Our approach: What we do. (Available from Partners in School Innovation, 1060 Tennessee Street, 2nd Floor, San Francisco, CA 94107)

Ladson-Billings, G. (2009). The dreamkeepers: Successful teachers of African American children. San Francisco, CA: Jossey-Bass.

Lambert, L. (2002). A framework for shared leadership. Educational Leadership, 59(8), 37.

LeCompte, M. D., \& Schensul, J. J. (1999). Analyzing and interpreting ethnographic data. Walnut Creek, CA.: AltaMira.

Lincoln, Y. S., \& Guba, E. G. (1985). Naturalistic inquiry. Beverly Hills, CA: Sage.

Little, J. W. (1982). Norms of collegiality and experimentation: Workplace conditions of school success. American Educational Research Journal, 19(3), 325-340.

Little, J. W. (1993). Teachers' professional development in a climate of educational reform. Educational Evaluation and Policy Analysis, 15(2), 129-151. doi:10.3102/01623737015002129

Little, J. W. (2001). Professional development in the pursuit of reform. In A. Lieberman \& L. Miller (Eds.), Teachers caught in the Action: Professional development that matters (pp. 23-44). New York, NY: Teachers College Press.

Lorenz, R., \& Pichert, J. W. (1989). Evaluation of education program developments: Illustration of the research and development cycle. The Diabetes Educator, 15(3), 253-256. doi:10.1177/014572178901500316

McElhone, D., \& Tilley, T. (2013). Following the teacher's lead in professional development to improve classroom talk around texts. Action in Teacher Education, 35(1), 3-18. doi:10.1080/01626620.2012.743445

McIntosh, P. (1988). White privilege and male privilege: A personal account of coming to see correspondences through work in women's studies (Working Paper No. 189). Wellesley, MA: Wellesley College, Center for Research on Women.

McKenzie, K. B., \& Scheurich, J. J. (2004). Equity traps: A useful construct for preparing principals to lead schools that are successful with racially diverse students. Educational Administration Quarterly, 40(5), 601-632. 
McKenzie, K. B., \& Scheurich, J. J. (2008). Teacher resistance to improvement of schools with diverse students. International Journal of Leadership in Education, 11(2), 117-133.

McLaren, P. (2007). Life in schools: An introduction to critical pedagogy in the foundations of education (5th ed.). Boston, MA: Pearson/Allyn and Bacon.

McLaughlin, M. W., \& Zarrow, J. (2001). Teachers engaged in evidence-based reform: Trajectories of teachers' inquiry, analysis, and action. In A. Lieberman \& L. Miller (Eds.), Teachers caught in action: Professional development that matters (pp. 79-101). New York, NY: Teachers College Press.

Mezirow, J. (1997, Summer). Transformative learning: Theory to practice. In P. Cranton (Ed.), New directions for adult and continuing education: No. 74. Transformative learning in action: Insights from practice (pp. 5-12). San Francisco, CA: JosseyBass.

Mezirow, J. (2000). Learning as transformation: Critical perspectives on a theory in progress (1st ed.). San Francisco, CA: Jossey-Bass.

Mezirow, J., \& Taylor, E. W. (2009). Transformative learning in practice: Insights from community, workplace, and higher education (1st ed.). San Francisco, CA: Jossey-Bass.

Miles, M. B., \& Huberman, A. M. (1994). Qualitative data analysis: An expanded sourcebook (2nd ed.). Thousand Oaks, CA: Sage.

Nieto, S. (2002). Language, culture, and teaching: Critical perspectives for a new century. Mahwah, NJ: L. Erlbaum.

Oregon Center for Educational Equity. (n.d.) Taking it up. Retrieved April 28, 2014, from (http://www.edequityoregon.com/equity-3/taking-it-up/)

Partners in School Innovation. (n.d.). About. Retrieved April 28, 2014, from (http://www.partnersinschools.org/)

Schensul, S. L., Schensul, J. J., \& LeCompte, M. D. (1999). Essential ethnographic methods: Observations, interviews, and questionnaires. Walnut Creek, CA: AltaMira Press.

Sfard, A. (1998). On two metaphors for learning and the dangers of choosing just one. Educational Researcher, 27(2), 4-13. 
Singleton, G. E., \& Linton, C. (2006). Courageous conversations about race: A field guide for achieving equity in schools. Thousand Oaks, CA: Corwin.

Sirota, E., \& Bailey, L. (2009). The impact of teachers' expectations on diverse learners' academic outcomes. Childhood Education, 85(4), 253.

Sleeter, C. E. (2001). Preparing teachers for culturally diverse schools: Research and the overwhelming presence of Whiteness. Journal of Teacher Education, 52(2), 94-106.

Stokes, L. (2001). Lessons from an inquiring school: Forms of inquiry and conditions for teacher learning. In A. Lieberman \& L. Miller (Eds.), Teachers caught in the action: Professional development that matters (pp. 141-158). New York, NY: Teachers College Press.

Tatum, B. D. (2003). "Why are all the Black kids sitting together in the cafeteria?" And other conversations about race. New York, NY: Basic Books.

Vanneman, A., Hamilton, L., Anderson, J. B., \& Rahman, T. (2009). Achievement gaps: How Black and White students in public schools perform in mathematics and reading on the National Assessment of Educational Progress (NCES 2009-455). Washington, DC: National Center for Education Statistics. 
APPENDIX A

PARTICIPANT CONSENT FORM 


\section{Dear Workshop Participant,}

Teri Tilley, fifth grade teacher and doctoral student, is completing a project-based dissertation through Portland State University. This study will help satisfy the requirements of her dissertation project. Participants will implement the strategies presented in the handbook, Keeping Equity in Mind, and participate in interviews, surveys and planning observations. The data collected will be used to revise the product in order to better meet the educational needs of teacher leaders continuing equity work in their classrooms.

While participants will be asked district demographic data, individuals and their districts will not be identified in the study. No original names/districts are needed in the written report of the findings. Participant information will be entirely confidential.

Please sign this informed consent as part of the requirements of research at PSU.

Please review and sign below.

I agree to participate in the problem-based study Keeping Equity in Mind. I understand that I will participate in interviews, observations, and complete a survey. The research from these assessments and surveys will be entirely confidential.

Thank you for your participation.

PRINT NAME

SIGNATURE DATE

EMAIL 
APPENDIX B

EQUITY INTERVIEW PROTOCOL 
Teri Tilley

Portland State University

Date:

Participant Code:

Participant Information:

Race:

Years Teaching:

Grade Level:

Gender: Number of Cycles Completed:

\section{$\underline{\text { Research Questions }}$}

\begin{tabular}{|c|c|c|}
\hline Question & Response & Notes \\
\hline $\begin{array}{l}\text { How long have you been in } \\
\text { education? What positions have } \\
\text { you held? }\end{array}$ & & \\
\hline $\begin{array}{l}\text { What have you been thinking } \\
\text { about since your participation in } \\
\text { equity training? }\end{array}$ & & \\
\hline
\end{tabular}




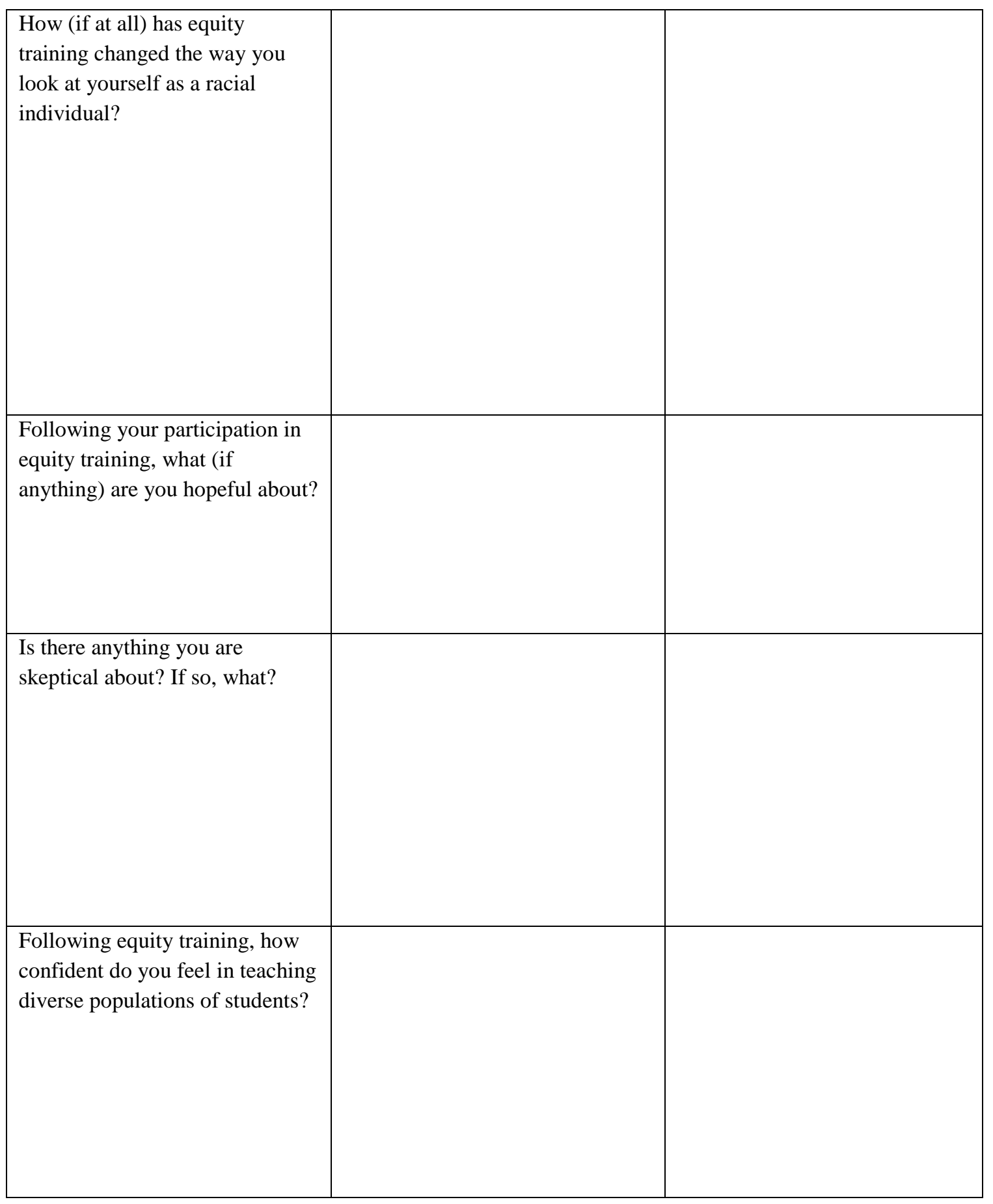




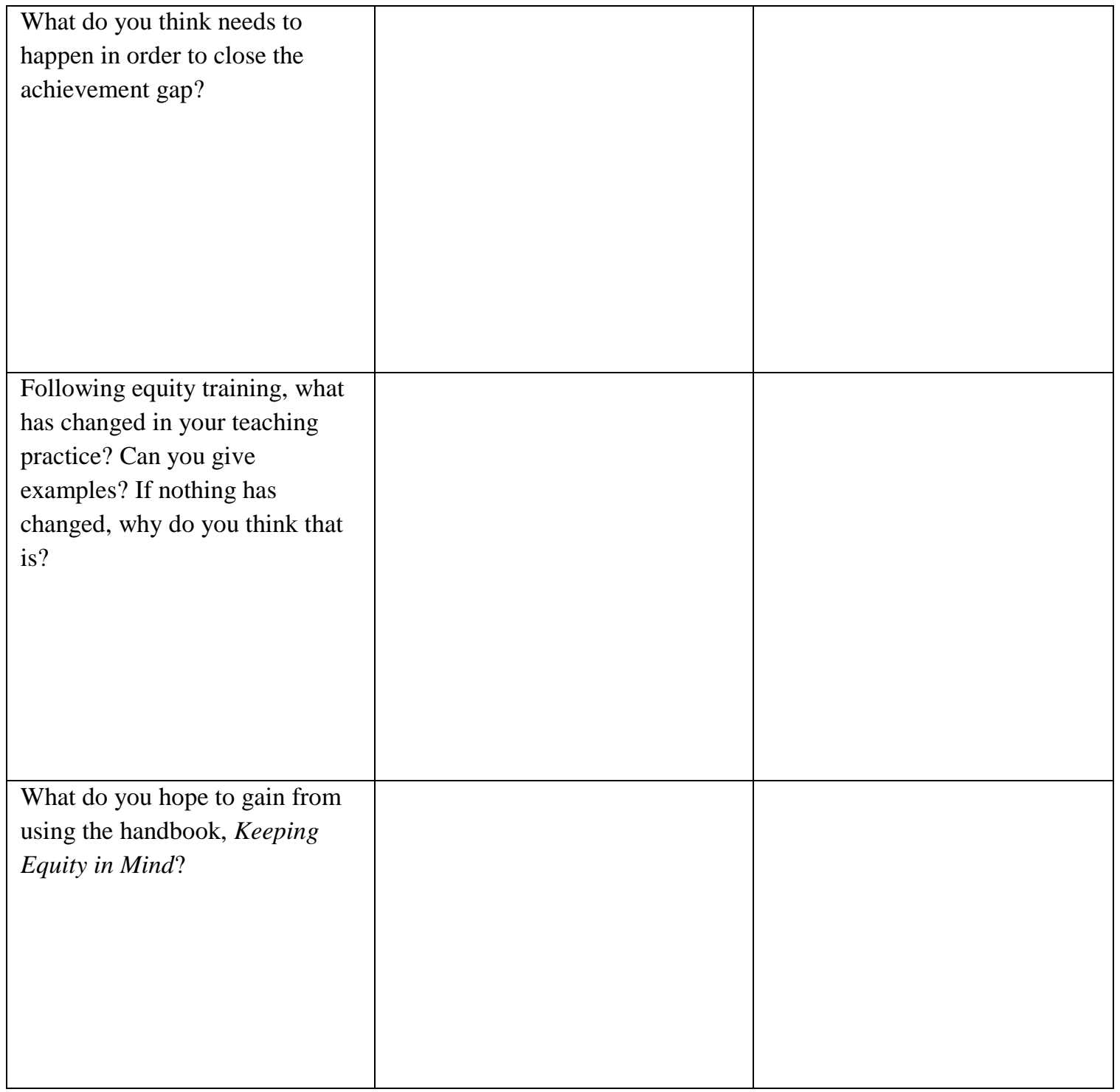


APPENDIX C

FINAL INTERVIEW PROTOCOL 
Teri Tilley

Portland State University

Date:

Participant Code:

\section{Participant Information:}

Race:

Years Teaching:

Grade Level:

Gender: Number of Cycles Completed:

\section{$\underline{\text { Research Questions }}$}

\begin{tabular}{|c|c|c|}
\hline Question & Response & Notes \\
\hline $\begin{array}{l}\text { How do you think the cycle } \\
\text { went? }\end{array}$ & & \\
\hline $\begin{array}{l}\text { How was your teaching practice } \\
\text { different while using Keeping } \\
\text { Equity in Mind? }\end{array}$ & & \\
\hline
\end{tabular}




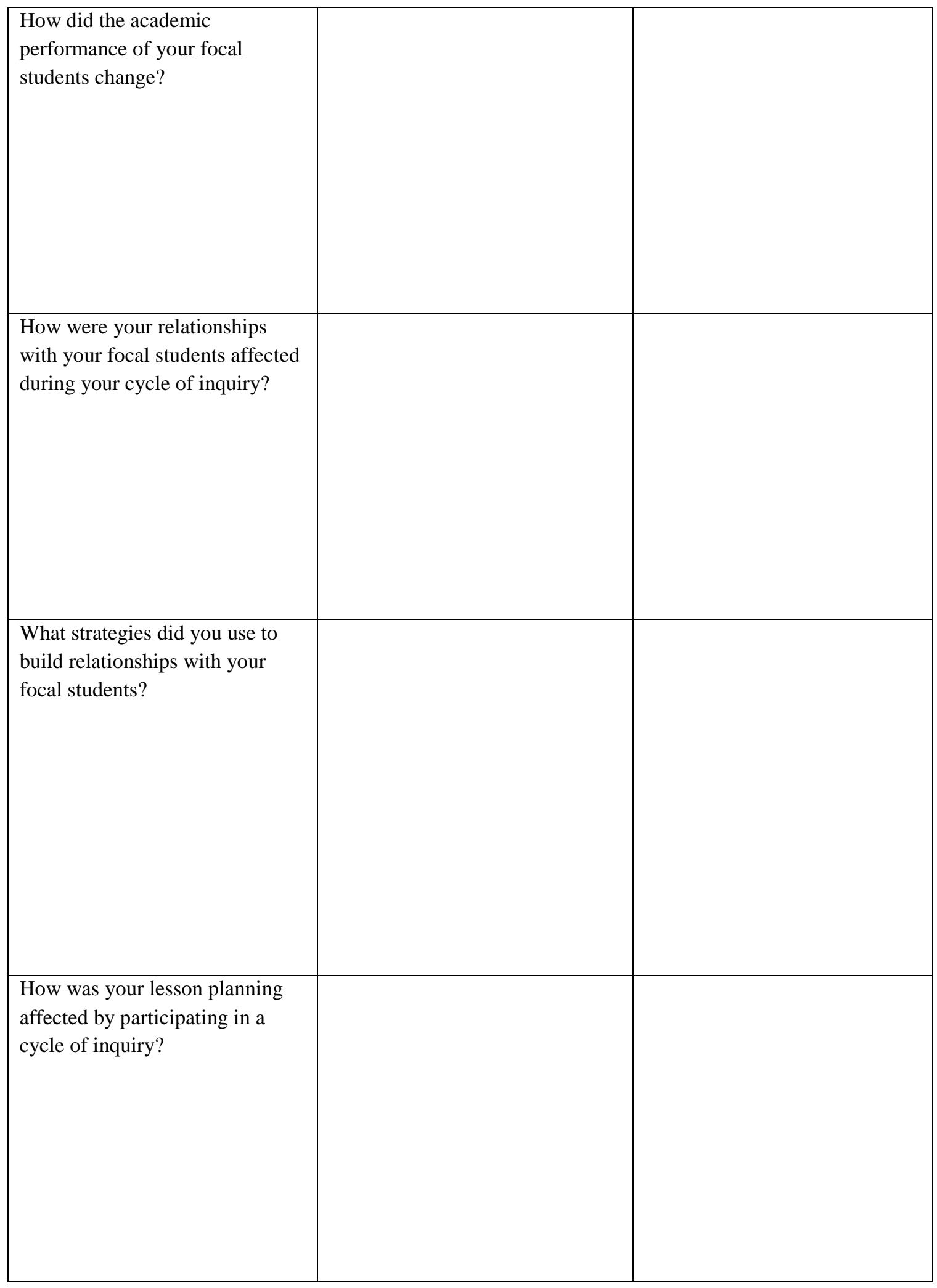




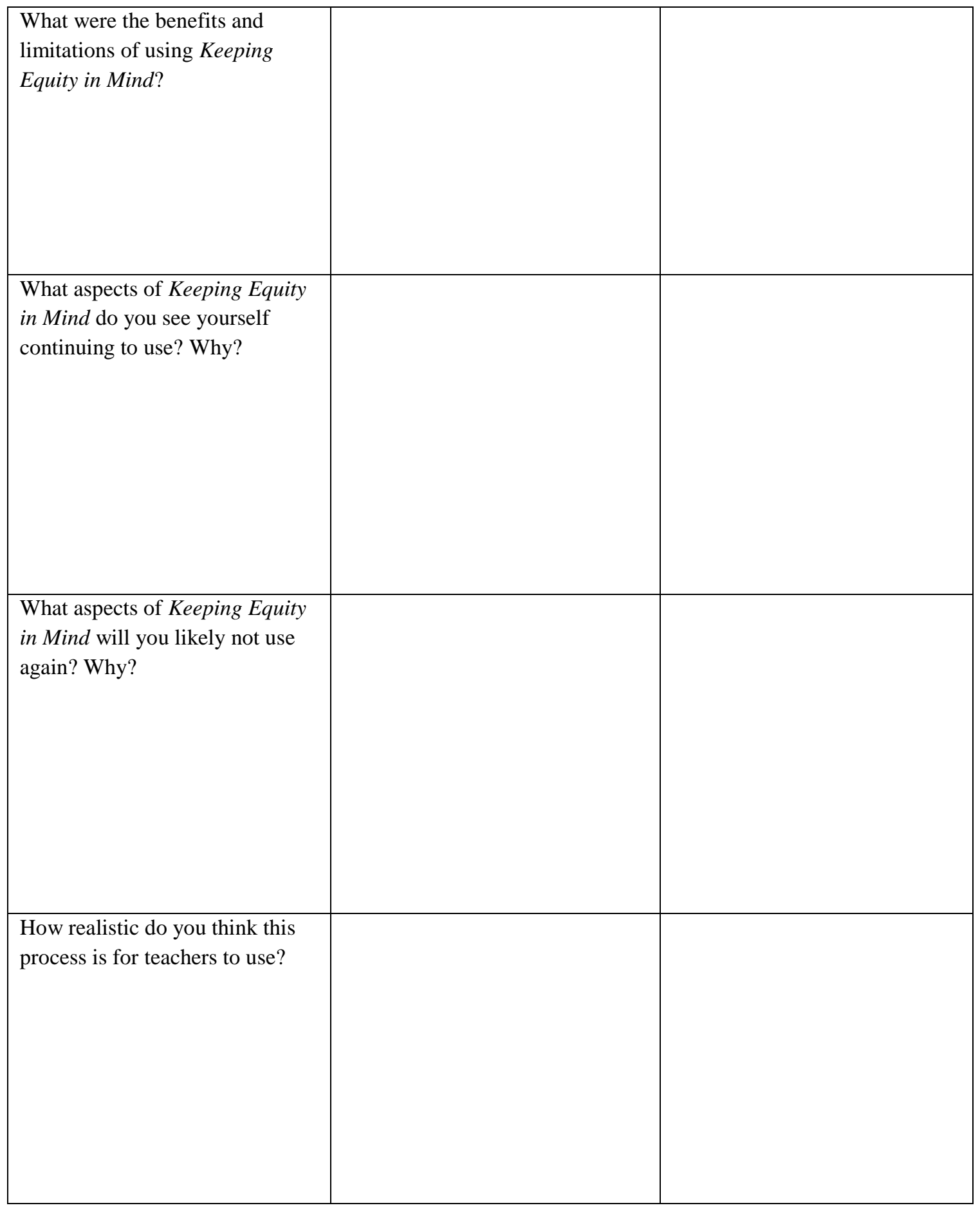




\begin{tabular}{|l|l|l|}
\hline $\begin{array}{l}\text { How (if at all) can this tool help } \\
\text { teachers close the achievement } \\
\text { gap? }\end{array}$ & & \\
\hline $\begin{array}{l}\text { Following the implementation of } \\
\text { Keeping Equity in Mind, how } \\
\text { confident do you feel in teaching } \\
\text { diverse populations of students? }\end{array}$ & & \\
& & \\
\hline $\begin{array}{l}\text { Is there anything else you would } \\
\text { like me to know regarding your } \\
\text { experience using Keeping Equity } \\
\text { in Mind? }\end{array}$ & & \\
\end{tabular}


APPENDIX D

PLANNING MEETING OBSERVATION PROTOCOL 
PLANNING MEETING OBSERVATION PROTOCOL

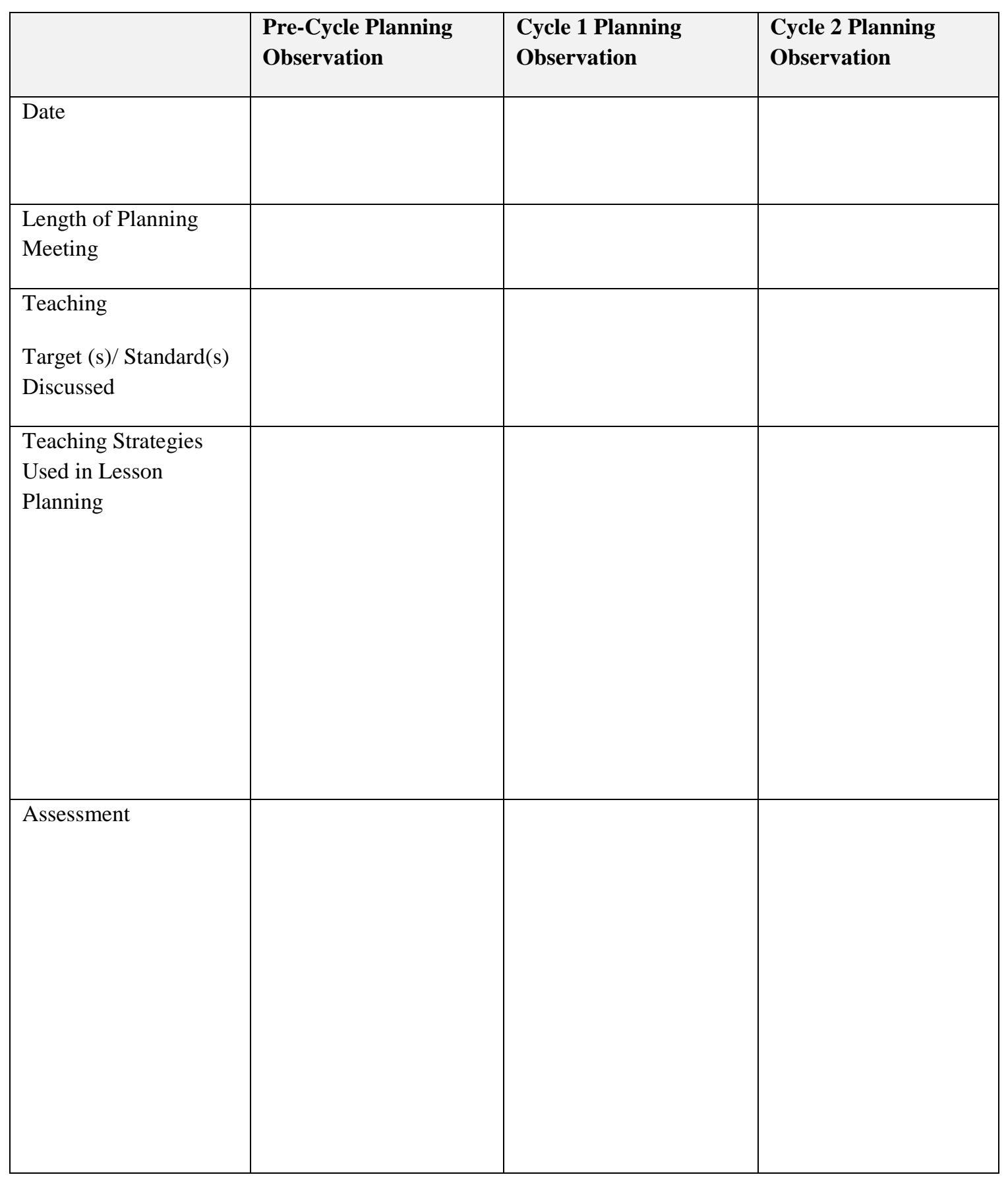




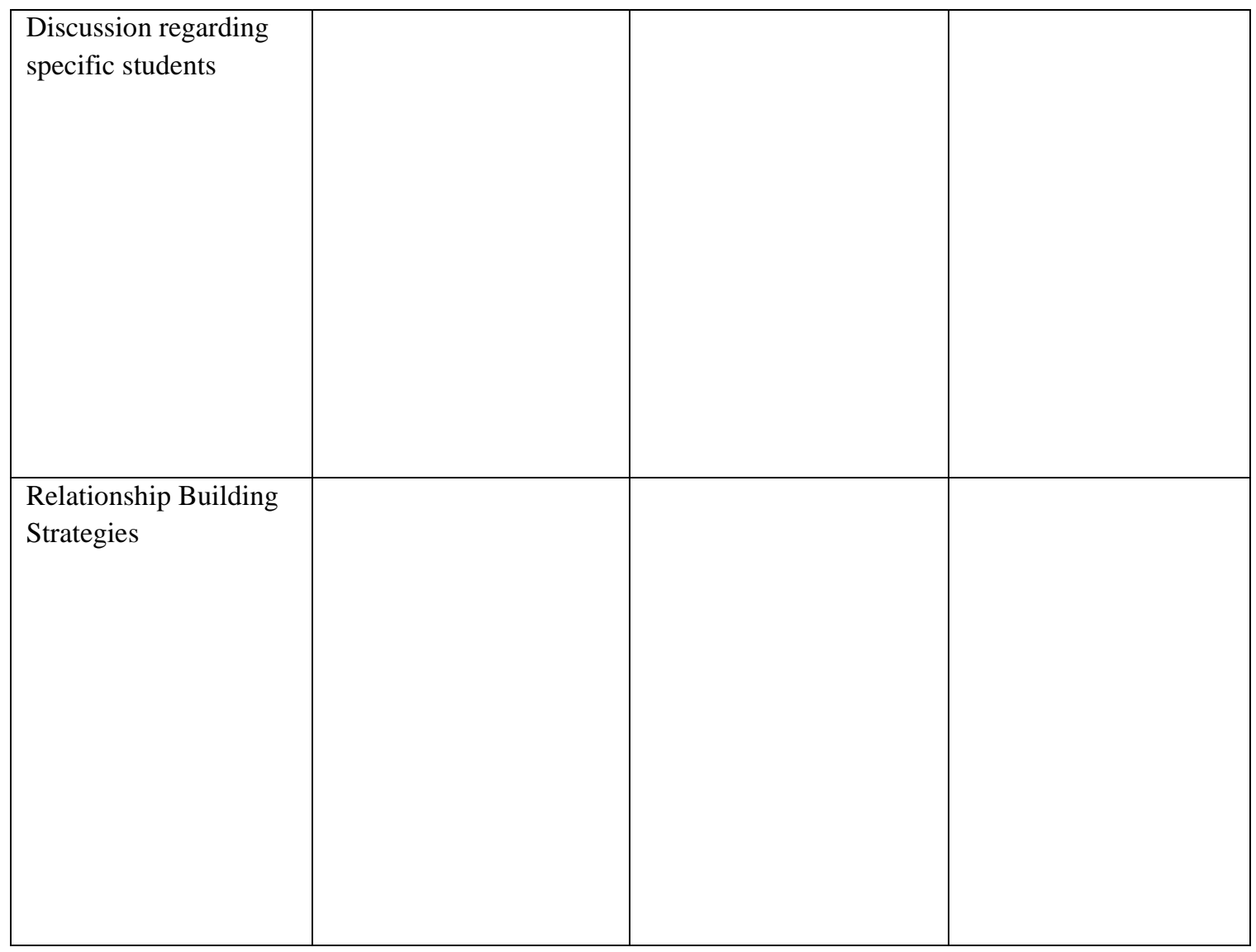


APPENDIX E

FINAL SURVEY 


\section{Final Survey: Keeping Equity in Mind}

Demogrphics

1. What is your job title?

Elementary Teacher

Secondary Teacher

Administrator

Instructional Coach

Other (please specify)

2. How long have you worked in the field of education?

This is my first year

2-4 years

5-7 years

8-10 years

11-13 years

14-16 years

17-19 years

20 or more years 


\section{Final Survey: Keeping Equity in Mind}

\section{Introductory Sections: About the Author, Why Does Equity Work Matter, and ...}

Usefulness of the handbook, Keeping Equity in Mind: A Tool for Teacher Leaders to Use While Planning Their Lessons in Order to Sustain Equity Work

Introductory Sections

Rate the usefulness of the handbook's introductory sections on a scale of 1 to 4 for usefulness of content information.

USEFULNESS is defined as practical information for teacher leaders attempting to continue equity work in their classrooms once formal equity training has ended. Is the content fully developed with necessary details and examples?

1 = Least Useful or the lowest, most negative perception of content information

$2=$ Not Useful

$3=$ Useful

4 = Most Useful or the highest, most positive perception of content information

How useful were the following sections of Keeping Equity in Mind to teacher leaders attempting to continue equity work in their classrooms once formal equity training has ended?

Note: You will want to have your copy of Keeping Equity in Mind with you when you answer the following questions.

\section{How useful is the Author's Note section?}

Least Useful

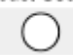

Not Useful

$\bigcirc$
Useful

$\bigcirc$
Most Useful

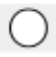

\section{What were the most useful and/or least useful aspects of this section?}

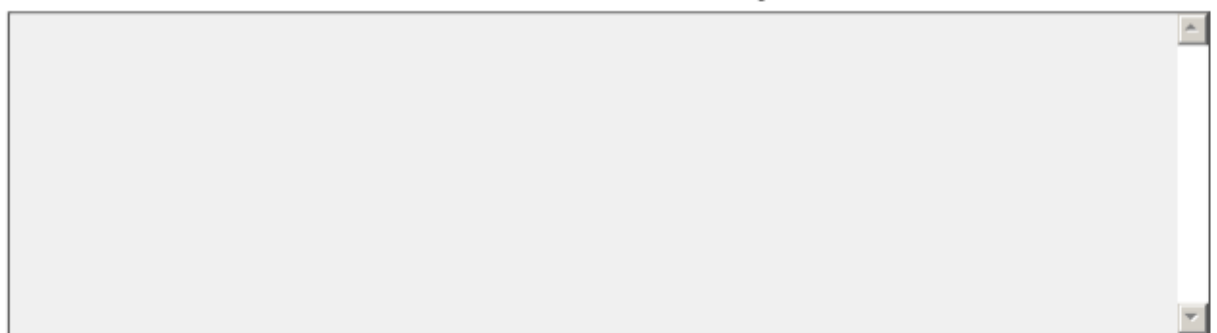

5. Is there anything that should be added to or deleted from this section? Why?

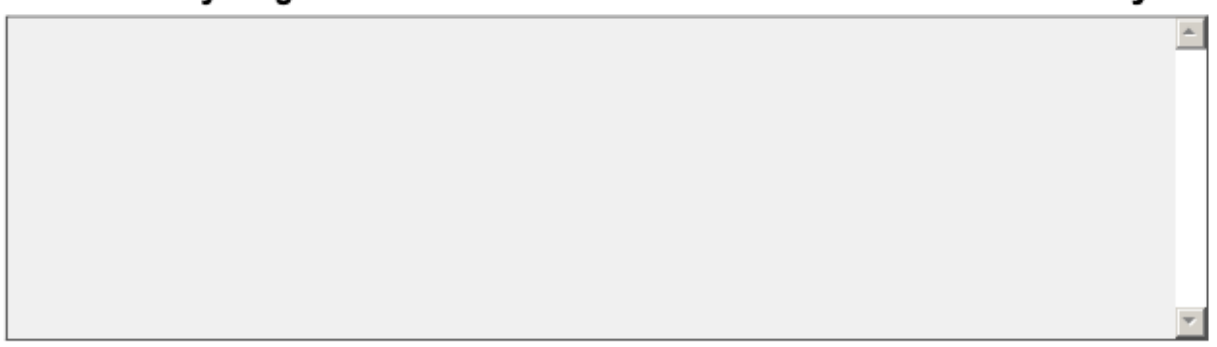




\section{Final Survey: Keeping Equity in Mind}

6. How useful was the About the Author section?

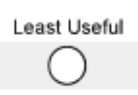

Not Useful

$\bigcirc$

Useful

Most Useful

7. What were the most useful and/or least useful aspects of this section?

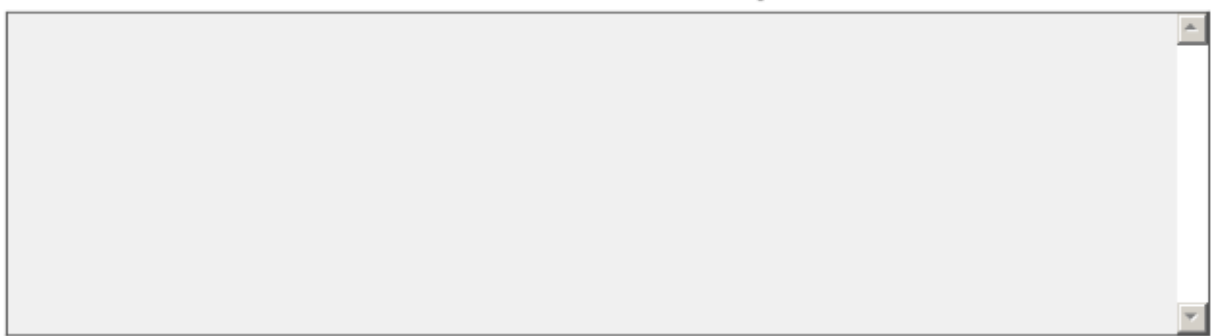

8. Is there anything that should be added to or deleted from this section? Why?

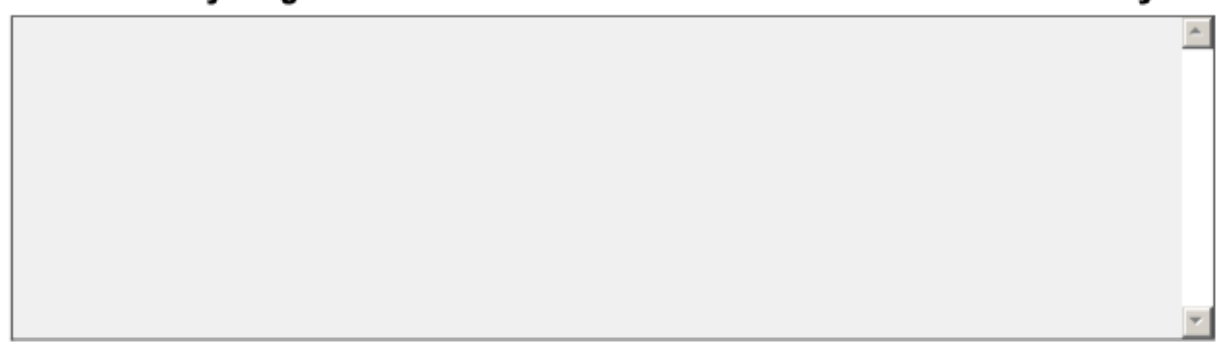

9. How useful was the Why Does Equity Work Matter section?
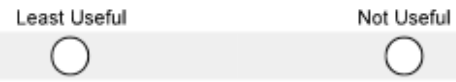

Useful

$\bigcirc$

Most Useful

$\bigcirc$

10. What were the most useful and/or least useful aspects of this section?

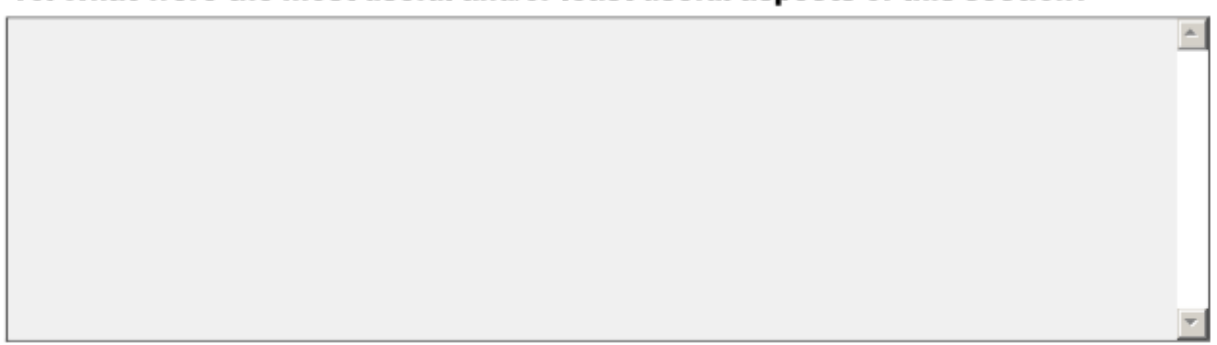




\section{Final Survey: Keeping Equity in Mind}

11. Should anything be added to or deleted from this section? Why?

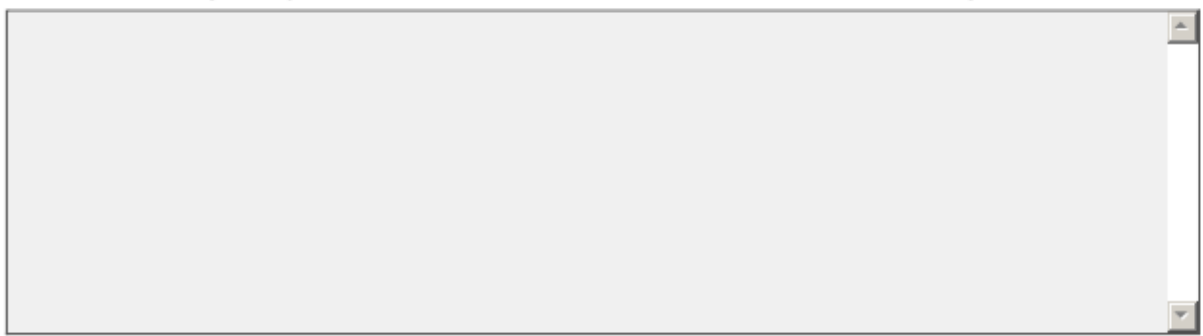

12. How useful is the section titled, How Does a Cycle of Inquiry Support My Work With Common Core Student Learning and Growth Goals?

Least Useful

Not Useful

Useful

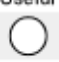

Most Useful

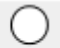

13. What were the most useful and/or least useful aspects of this section?

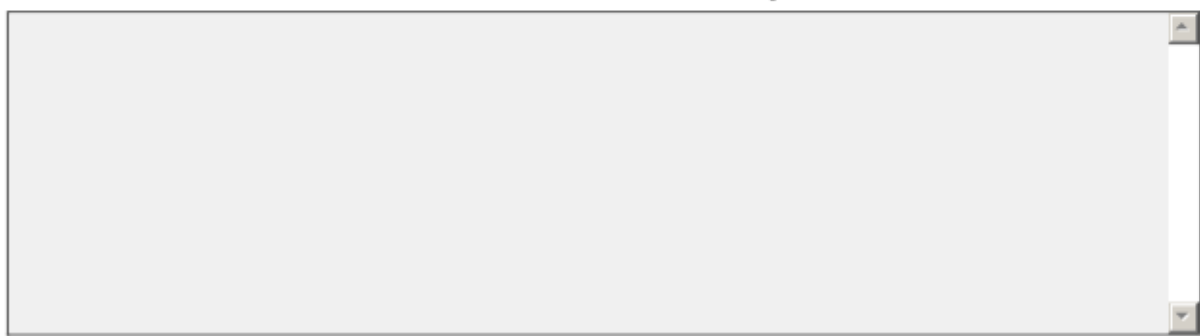

14. Is there anything that should be added to or deleted from this section? Why?

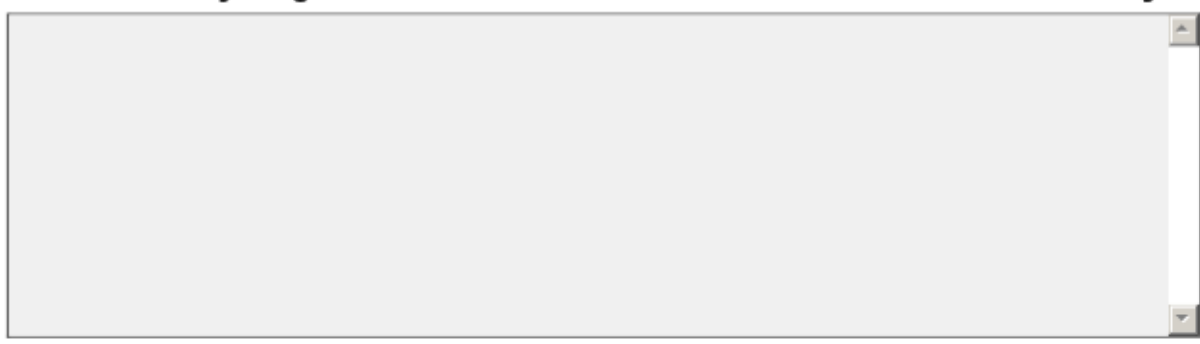

15. How useful is the Congratulations section?

Least Useful

Not Useful

Useful

Most Useful

$\bigcirc$

O

O 


$$
=
$$




\section{Final Survey: Keeping Equity in Mind}

\section{Getting Started}

In this section, you will answer questions regarding the usefulness of the section of the handbook dedicated to getting you started.

18. How useful is the How Do We Determine Focal Students section?

Least Useful

$\bigcirc$
Not Useful

$\bigcirc$
Useful

$\bigcirc$
Most Useful

$\bigcirc$

19. How useful was the process of identifying focal students and targeting lessons to meet their needs?

Least Useful

$\bigcirc$

Not Useful

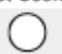

Useful

$\bigcirc$

Most Useful

$\bigcirc$

20. What were the most useful and/or least useful aspects of this section?

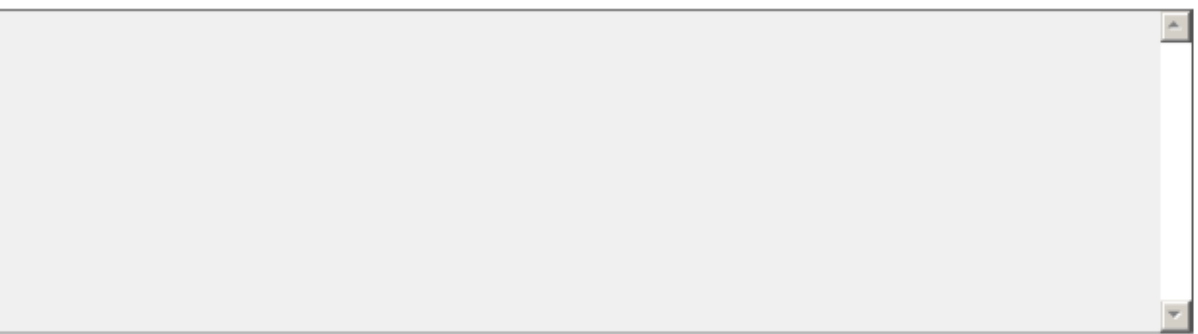

21. Is there anything that should be added to or deleted from this section? Why?

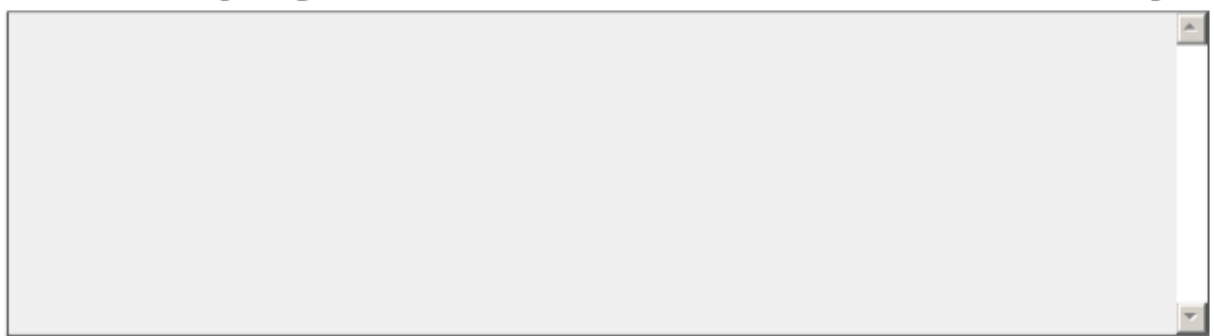

22. How useful was the Ripple Effect section?

Least Useful

$\bigcirc$
Not Useful

$\bigcirc$
Useful

$\bigcirc$
Most Useful

0 


\section{Final Survey: Keeping Equity in Mind}

23. What were the most useful and/or least useful aspects of this section?

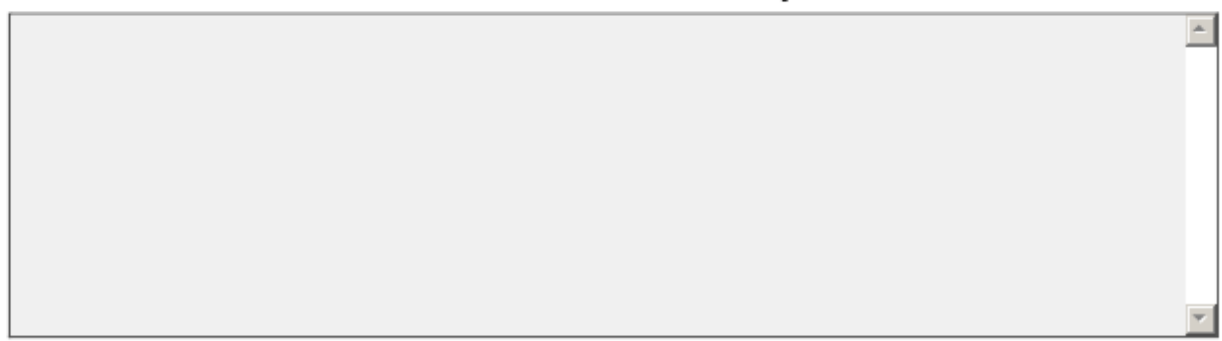

24. Is there anything that should be added to or deleted from this section? Why?

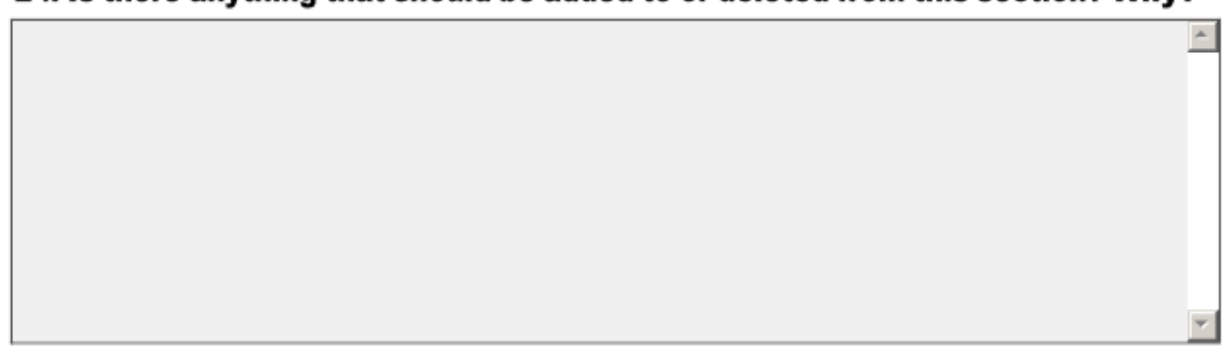

25. How useful was the Achievement Zones section?

Least Useful

$\bigcirc$
Not Useful

$\bigcirc$
Useful

$\bigcirc$
Most Useful

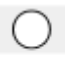

26. What were the most useful and/or least useful aspects of this section?

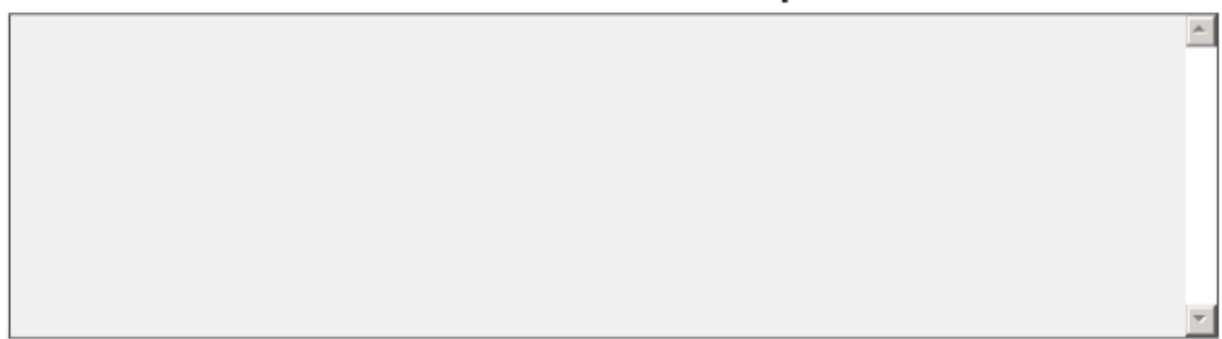

27. Is there anything that should be added to or deleted from this section? Why?

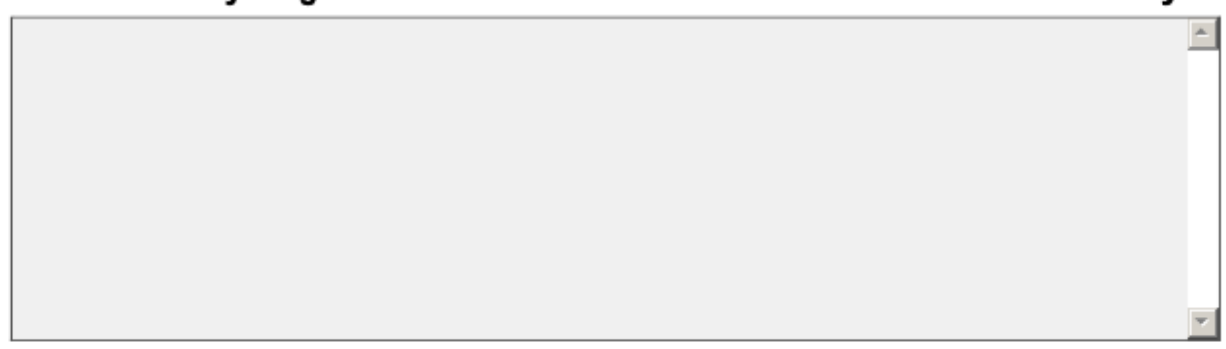




\section{Final Survey: Keeping Equity in Mind}

28. How useful was the Identifying Focal Students section? Least Useful $\bigcirc$

Not Useful

Useful

Most Useful

29. Is there anything you would change about this form?

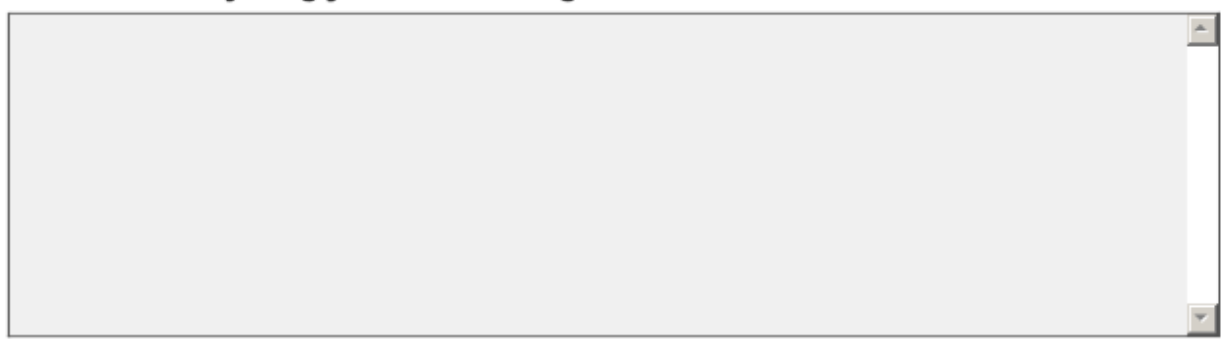




\section{Final Survey: Keeping Equity in Mind}

\section{Strategies for Building Strong Relationships with Your Focal Students}

In this section, you will answer questions regarding the usefulness of the section in the handbook dedicated to strategies for building strong relationships with your focal students.

30. How useful is the Building Strong Relationships section?

Least Useful

$\bigcirc$
Not Useful

$\bigcirc$
Useful

$\bigcirc$
Most Useful

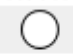

31. How useful is the Further Resources in the Building Relationships section?

Least Useful

$\bigcirc$
Not Useful

$\bigcirc$
Useful

$\bigcirc$
Most Useful

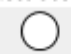

32. Comments regarding the usefulness of the above strategies:

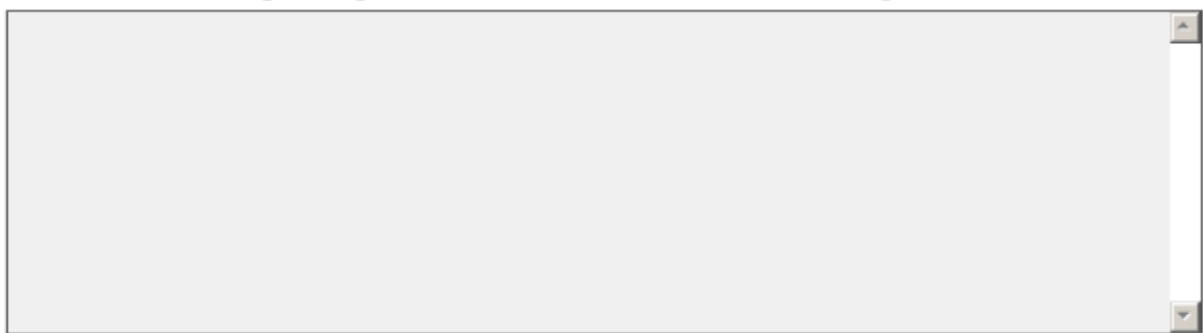

33. Are there any strategies for building relationships you think I should add to this section? 


\section{Final Survey: Keeping Equity in Mind}

\section{Equitable Teaching Practices}

In this section, you will answer questions regarding the usefulness of the section in the handbook dedicated to equitable teaching practices.

34. How useful is the discussion about Equity v. Equality?

Least Useful

$\bigcirc$
Not Useful

$\bigcirc$
Useful

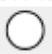

Most Useful

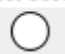

35. How useful is the Equality/Equity graphic?

Least Useful

0
Not Useful

0
Useful

Most Useful

36. Comments regarding the Equity v. Equality section:

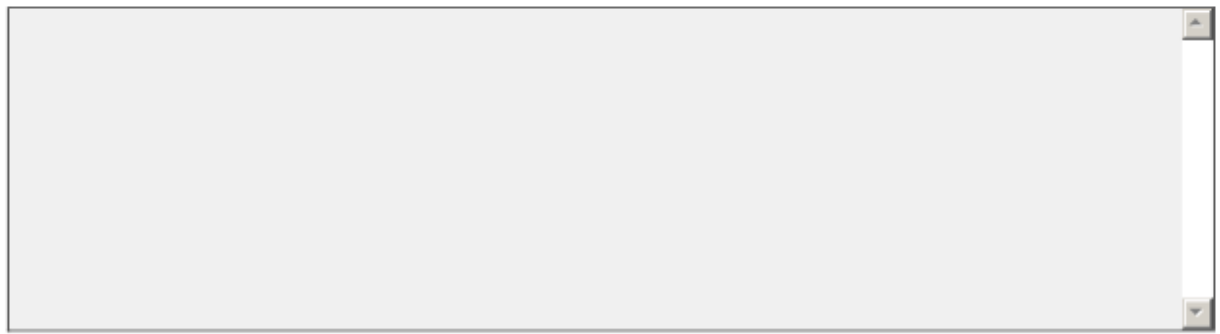

37. How useful was the Equitable Teaching Strategies section?

Least Useful

0
Not Useful

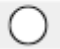

Useful

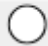

Most Useful

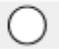

38. How useful are the Further Resources for Equitable Teaching Strategies?

Least Useful

0
Not Useful

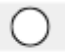

Useful

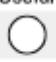

Most Useful ○

39. Any comments regarding this section? 


$$
\text { - }
$$




\section{Final Survey: Keeping Equity in Mind}

\section{The Cycle of Inquiry}

In this section, you will answer questions regarding the usefulness of the section in the handbook dedicated to the cycle of inquiry.

41. How useful was the What is a Cycle of Inquiry section?

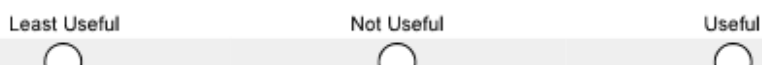

$\bigcirc$

Most Useful

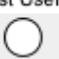

42. How useful was the Why Should We Use a Cycle of Inquiry section in helping you understand the value of using a cycle of inquiry?
Least Useful
Not Useful
0

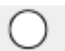
Useful
Most Useful

43. How useful was the Inquiry Based Professional Development section?

Least Useful

0

Not Useful

0

Useful

0

Most Useful

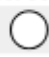

44. How useful was the Cycle of Inquiry graphic (Figure 1)?

Least Useful

0

Not Useful

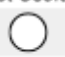

Useful

Most Useful

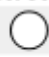

45. How useful were the Determining a Focus for Inquiry into Practice section?
Least Useful
Not Useful
Useful
0
0
0
Most Useful

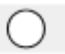

46. How useful was the Determining Measurable Goals section?

Least Useful

0
Not Useful

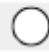

Useful

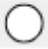

Most Useful

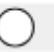

47. How useful was the Creating an Action Plan section?

Least Useful

$\bigcirc$
Not Useful

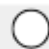

Useful

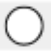

Most Useful

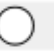

48. How useful was the Creating an Action Plan section?

Least Useful

0
Not Useful

$\bigcirc$
Useful

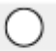

Most Useful

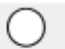

49. How useful was the Collecting and Analyzing Data section?

Least Useful

$\bigcirc$
Not Useful

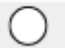

Useful

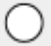

Most Useful

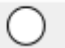

50. How useful was the Determining Next Steps section?

Least Useful

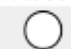

Not Useful

Useful

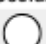

Most Useful

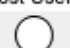




$$
=
$$




\section{Final Survey: Keeping Equity in Mind}

\section{Forms}

In this section, you will evaluate the usefulness of the forms provided in Keeping Equity in Mind.

53. How useful was the Getting to Know you Survey?

Least Useful

Not Useful

Useful

Most Useful

$\bigcirc$

$\bigcirc$

$\bigcirc$

$\bigcirc$

54. How useful was the Getting to Know Your Student survey?

Least Useful

$\bigcirc$
Not Useful

$\bigcirc$
Useful

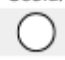

Most Useful

$\bigcirc$

55. Would you use either of these forms in the future?

Yes

No

56. How useful was the Identifying Focal Students form?

Least Useful

0
Not Useful

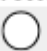

Useful

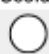

Most Usefu

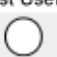

57. Will you use this form in the future?

$\bigcirc$ Yes

No

58. How useful was the Pre-Cycle Planning Form?

Least Useful

0
Not Useful

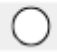

Useful

Most Useful

59. Will you use this form in the future?

$\bigcirc$ Yes

No

60. Would you like to have the option of getting these forms online?

$\bigcirc$ Yes

No 


\section{Final Survey: Keeping Equity in Mind}

\section{Overall Value of Your Experience}

In this section, you will evaluate your experience using Keeping Equity in Mind.

61. I will continue to use a cycle of inquiry model to plan my lessons.

Definitely Not

No

Yes

Definitely Will

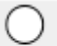

$\bigcirc$

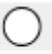

$\bigcirc$

62. I will continue to focus my lessons to meet the needs of my focal students.

Definitely Not

$\bigcirc$
No

$\bigcirc$
Yes

$\bigcirc$
Definitely Yes

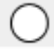

63. I will continue to use strategies from this handbook to build strong relationships with my students.

Definitely Not (
No

$\bigcirc$

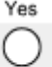

Definitely Will

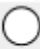

64. I will continue to use the equitable teaching strategies I used in this process.

Definitely Not 0
No

0
Yes

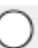

Definitely Will $\bigcirc$

65. How useful a tool is Keeping Equity in Mind for teachers dedicated to teaching equitably?

Least Useful 0
Not Useful

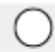

Useful

Most Useful 


\section{Final Survey: Keeping Equity in Mind}

\section{Share Your Thoughts}

In this section, please feel free to share any thoughts, concerns, questions, opinions you have regarding the usefulness of Keeping Equity in Mind.

66. Please feel free to share any thoughts, concerns, questions, or opinions you have regarding the usefulness of Keeping Equity in Mind.

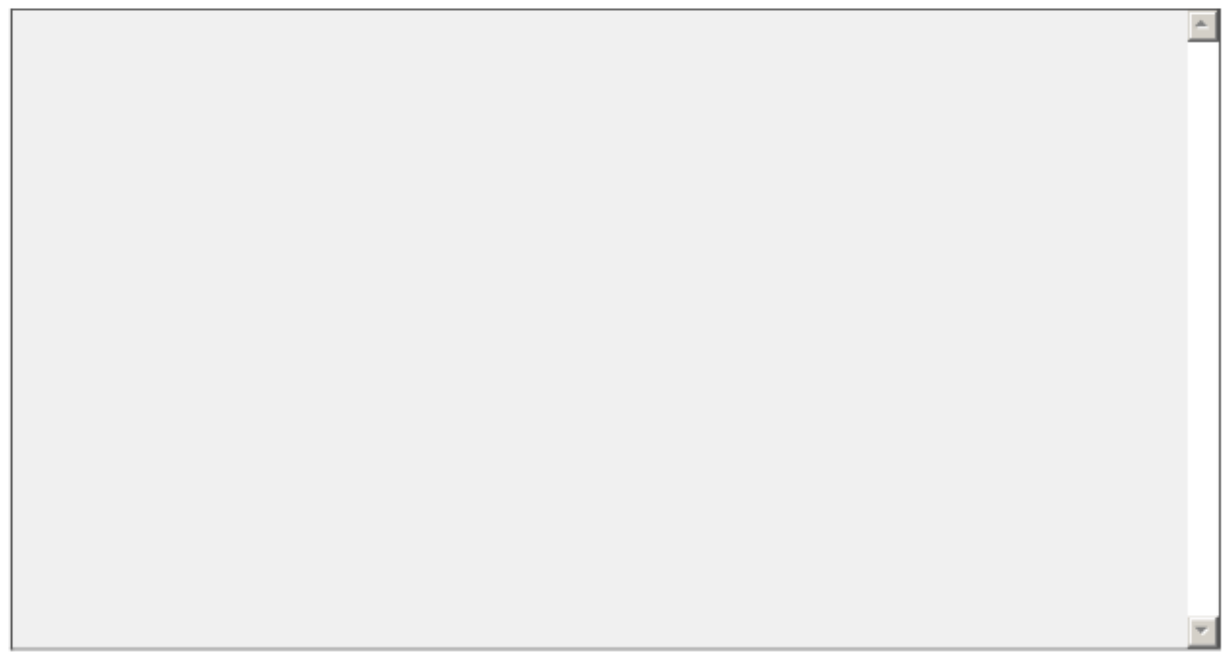




\section{APPENDIX F}

INFORMATIONAL MEETING POWERPOINT PRESENTATION 


\section{Keeping Equity in Mind}

January 21, 2014

\section{Purposes of Our Work Together}

- Support you in continuing equity work in your classrooms

- Gather data regarding the usefulness of Keeping Equity in Mind

- Use your feedback to revise Keeping Equity in Mind in order to better support teachers as they continue equity work in their classrooms

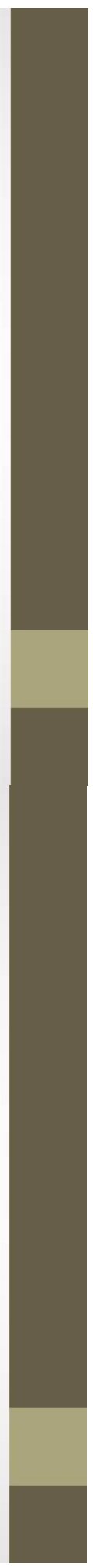




\section{Where Are You?}

- What has been going through your mind since equity training?

- Do you feel participating in Taking it Up has given you the strategies and skills you need to plan lessons that will lead to higher achievement for your students of color?

-What do you feel you need in order to teach more equitably in your classrooms?

\section{Equality v Equity}

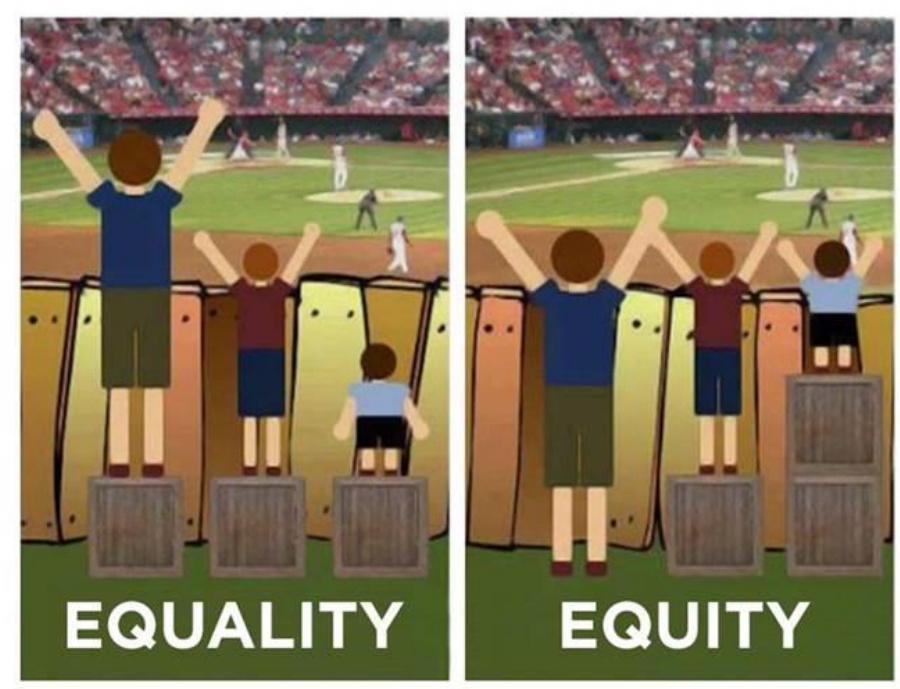




\section{Focal Students}

- Students of color who are not meeting standard

- Based on State Assessment data as well as pre-tests

- Students who fall in the yellow zone

- Within one year of meeting standard

- You will design lessons with these students in mind in order to engage and motivate them

\section{Cycle of Inquiry}

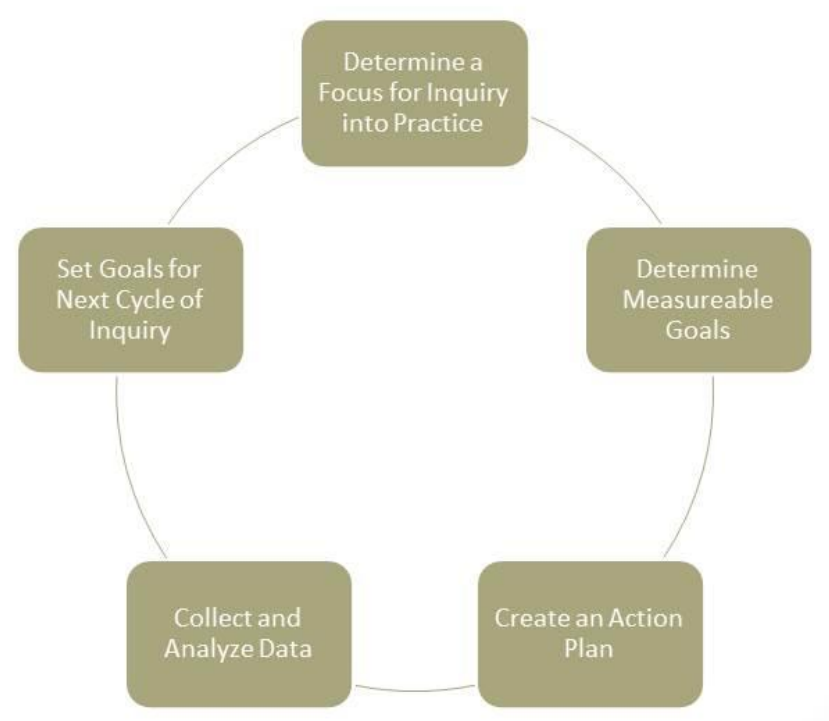




\section{Next Meeting}

- Complete Online Interview

- Read Through Handbook

- Fill Out Data Collection Sheet

- Select Focal Students

- Try Strategies for Building Strong Relationships

- Determine Standard for Cycle of Inquiry

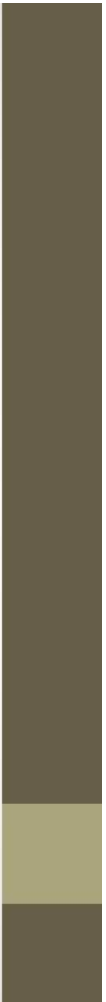


APPENDIX G

KEEPING EQUITY IN MIND TOOL 


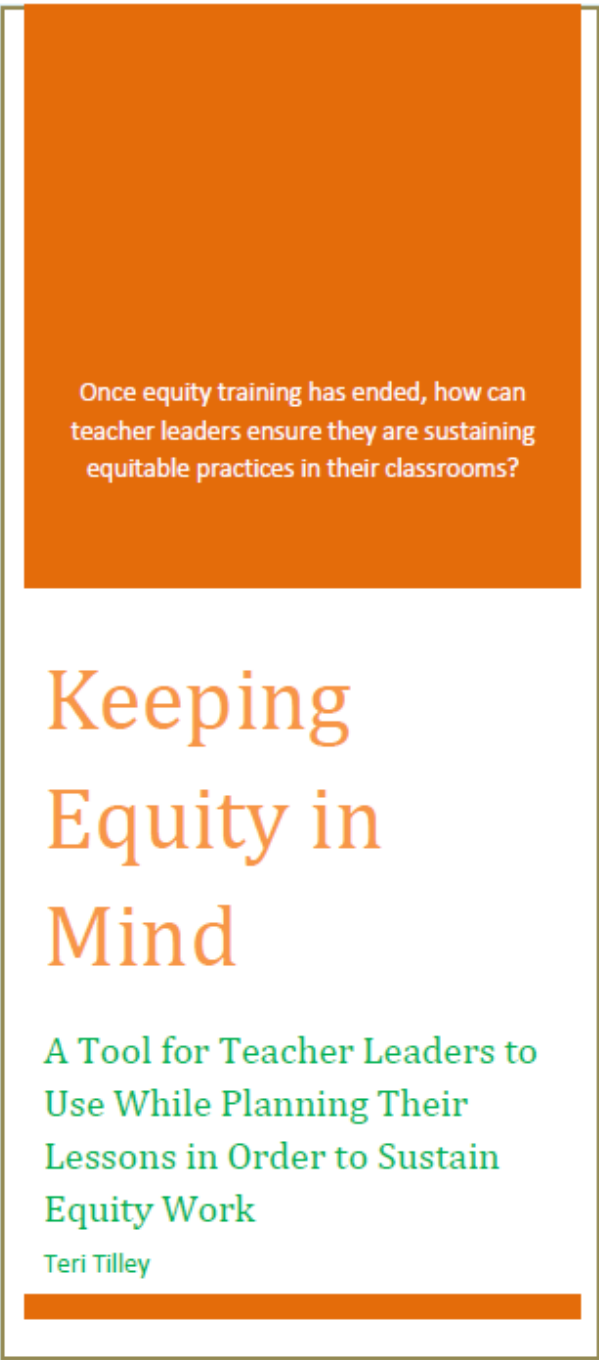


Keeping Equity in Mind:

A Tool for Teacher Leaders to Use While Planning Their Lessons in Order to Sustain Equity Work

Teri L. Tilley 


\section{Author's Note}

As educators striving to achieve equity for all students, it is clear racial equity is only one piece of the puzzle. I strongly believe, as educators, we need to endeavor to teach in a manner that is rigorous enough to ensure girls achieve in math and science at the same level as their male classmates; we need to fight for the equal representation of students in our LGBT communities - insuring they see themselves reflected in the materials we select, and we need to ensure we are reaching our students with special needs in a way that provides equitable access to a rigorous and authentic educational experience.

As educators, we struggle to meet the needs of all of our students every single day. Thankfully, our school districts are starting to recognize we can't win this battle alone-we need help. Districts across the nation are beginning to provide professional development to close achievement gaps - in my experience, racial achievement gaps, and for this reason, Keeping Equity in Mind focuses on strategies educators can use in order to take steps toward closing the racial achievement gap in their own classrooms. This does not mean, however, we can or will forget about other marginalized groups and stop striving to deliver equitable outcomes to them every single day we enter the classroom.

Therefore, it is my assumption that the educators using this handbook have already participated in formal equity training in their school districts and are aware of how privilege and institutionalized forms of racism affect the academic success of their students of color. For that reason, I do not go into great detail regarding the educational research on the need for educators to participate in equity training in order to meet the academic needs of all their students. It is my assumption that those using this handbook are dedicated to continuing equity work in their classrooms even in the absence of continued equity training. 


\section{About the Author}

For the past eleven years, I have been an educator in Title I schools in both California and Oregon, and I have had the opportunity to work with students from diverse cultural and socioeconomic backgrounds. I was fortunate enough to work at Cole Elementary (San Jose, California) where teachers and administrators actively strive towards closing the achievement gap between Black and Latino students and their Asian and White classmates.

While Cole evolved to become a school dedicated to closing the achievement gap, this was not always the case. In my first year of teaching at Cole, I blamed the circumstances with which my students were dealing for their lack of engagement or success at reaching benchmark. I often heard my colleagues (and myself) say things such as, "His father is unemployed, and his mother is a drug user. Of course he isn't doing well; he has too much to worry about at home." Another commonly used statement to legitimize poor student engagement and achievement was, "Both his parents are working two to three jobs, and he is taking care of his siblings and himself; no wonder he isn't doing his homework and he is falling asleep in class."

After using these excuses, I realized I was giving myself justification for not educating children based on extraneous circumstances. Of course it makes an educator's job easier if there is someone at home doing homework with a student, but it is not acceptable to say certain children won't learn because their circumstances are less than ideal. I could not believe that after one year, I had allowed several students to fall through the cracks. Imagine how many students had fallen through the cracks due to my colleagues who had been justifying the lack of student performance based on familial circumstances for the majority of their careers. Because of the educational gap between students of color and their White peers, and Cole's placement on Program Improvement, the administration decided it was time to dig deeper into the racial issues perpetuating the achievement gap at Cole, and this decision made all the difference.

When I first began teaching at Cole, the school was ranked 2 out of 10 against similar schools on the Annual Performance Index. Teachers began to ask the question, "What am I doing to 
ensure all my students are accessing state standards?" The focus shifted from, Why aren't these kids learning what I am teaching them, to How can I deliver the material in a way that is culturally relevant to all of my students thereby increasing engagement and learning? It was at this moment that things at Cole began to shift.

We came to the conclusion that the reason students were not meeting benchmark was because the system was not working for them. We realized we had biases that were keeping us from successfully educating our students of color. We were blaming our students (and their families) for their lack of success. It was no longer a question of how we teach this unit of study better, but of how we teach this unit of study so that all students have access to the information.

In questioning our own belief systems, we began to challenge our assumptions regarding the educational system and our students' capabilities, and we began to look at individual children in order to foster personal relationships, understand their backgrounds, and plan our curricular objectives to meet their needs. It did not take long to realize the relationship between culture, curriculum, and practice would be the first step in beginning to close the achievement gap.

Through work with Partners in School Innovation and EdEquity, teachers at Cole began to have pedagogical and philosophical shifts regarding their instructional practices. By designing our curriculum to meet the needs of all of our students, and by ensuring we had equally rigorous standards for our students of color, we began to see immediate shifts in student achievement. When we began having these conversations in 2003 , only $13 \%$ of Cole's Latino students were reading at grade level. By $2006,40 \%$ of Latino students were reading at grade level, and Cole ranked 10 out of 10 against similar schools on the Annual Performance Index. In a few short years, we went from a school in the first stages of Program Improvement to a California Distinguished School.

My experience at Cole demonstrated that all children can learn if curriculum is thoughtfully addressed in ways that are culturally relevant and authentic to students' experiences. 
Unfortunately, however, I was disheartened to learn that once our administrator retired, and a new administrator was brought to Cole, Cole once again found itself underserving its students of color. In only two years under their new administrator, Cole was, again, scoring much lower than similar schools and not meeting Adequate Yearly Progress (AYP). Upon hearing this news, I realized teachers need support in continuing equity work, so they can empower themselves to impact student learning in their classrooms even if equity training in their building has concluded. Educators need to create their own environment where they are capable of critically analyzing their practice and beliefs to meet student needs. It is crucial that conversations surrounding race and its link to student achievement begin to become part of teacher leaders' regular conversations regarding student success. I am hopeful Keeping Equity in Mind will be an effective tool educators can use to ensure they continue equity conversations and thoughtful planning for equitable instruction long after their training has ended. 


\section{Table of Contents}

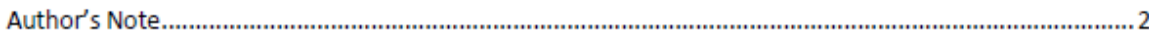

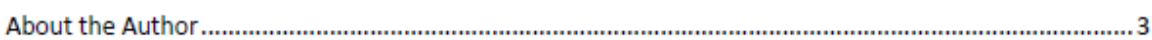

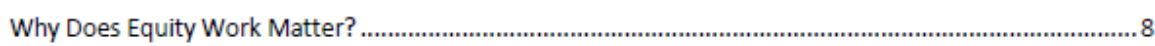

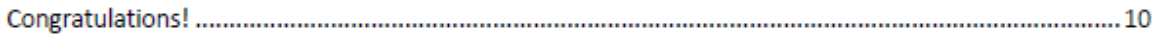

How Does a Cycle of Inquiry Support My Work with Common Core Student Learning and Growth Goals?

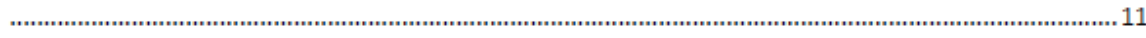

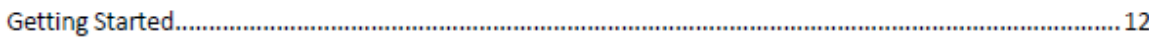

How Do We Determine Our Focal Students? .................................................................................... 12

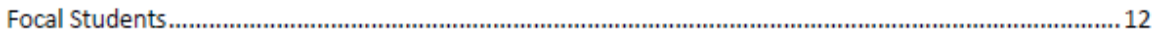

Performance Levels and Achievement Zones ..................................................................................13

Limited Progress Toward Standard-The Red Zone ...................................................................... 13

Progressing Toward Standard -The Yellow Zone...............................................................................14

Meets Standard-The Green Zone ................................................................................................... 14

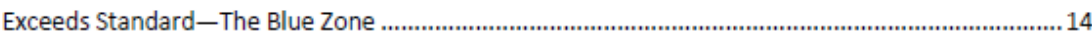

Tools for Identifying Focal Students ................................................................................................... 15

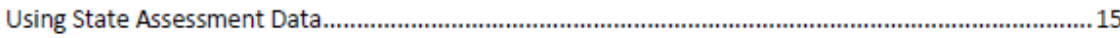

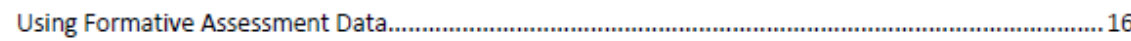

What Happens After I Have Selected My Focal Students? ..................................................................16

Do Your Focal Students Believe They Can Learn? ................................................................................1 17

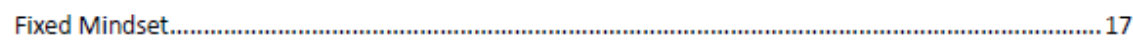

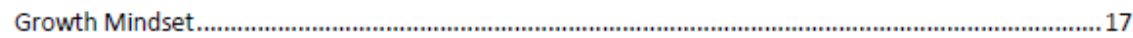

What Do I Do With the Mindset Quiz Results? ...................................................................................... 20

Use Statements that Encourage a Growth Mindset ...........................................................................20

Strategies for Building Relationships with Your Focal Students ...............................................................2 22

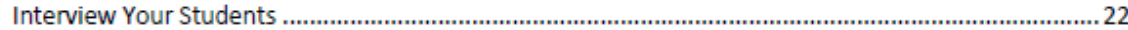

Give Assignments that Highlight Students' Experiences and Interests .............................................23

Allow Students to be the Center of Attention ................................................................................. 24

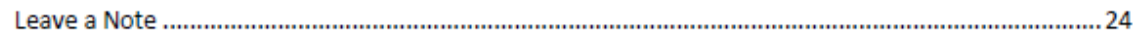

Attend Students' Extra-Curricular Activities ......................................................................................24

Make a Positive Phone Call Home ..........................................................................................................2

Visit Your Students' Communities ........................................................................................................2 25 
Hang out With Your Students Outside of the Classroom

Equitable Teaching Strategies..................................................................................................................2 28

Welcome Students by Name as They Enter the Classroom.................................................................28

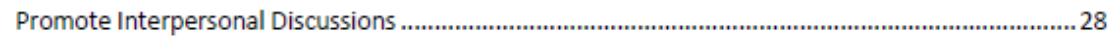

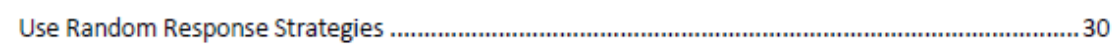

Get Multiple Perspectives .............................................................................................................. 31

Ask High-Order Questions of All Students ................................................................................ 31

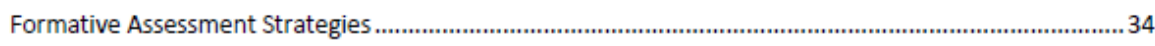

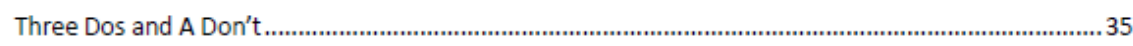

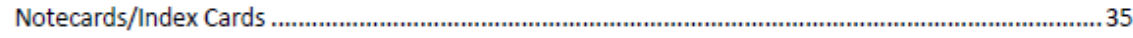

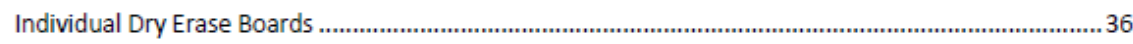

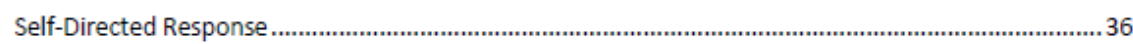

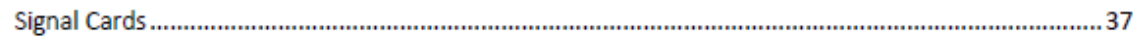

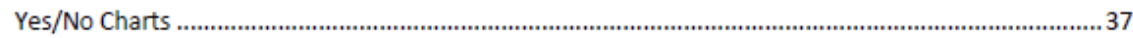

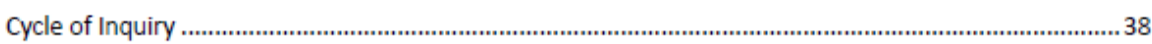

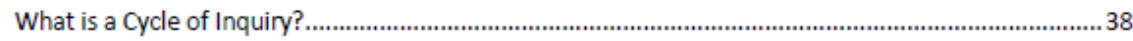

Why Should We Use a Cycle of Inquiry? ................................................................................... 38

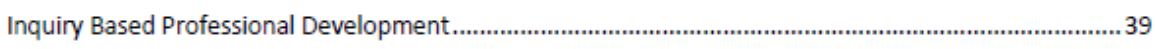

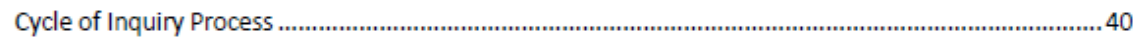

Determining a Focus for Inquiry into Practice ........................................................................ 41

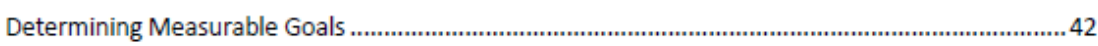

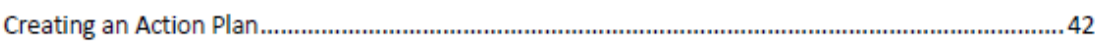

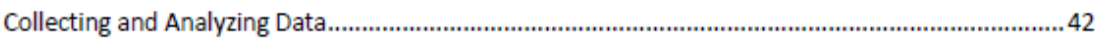

Determining Next Steps Based on Data................................................................................... 43

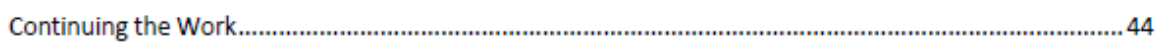

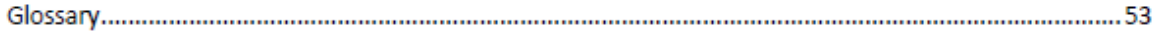




\section{Why Does Equity Work Matter?}

Because our nation has experienced and endured two centuries of slavery, a century of courtsanctioned segregation by race, and yet another half century of discrimination and differential access to education based on language, class, race and background, it is becoming increasingly clear that our nation has become accustomed to educational inequalities that lead to lowered student achievement for children of color (Darling-Hammond, 2007). While we, as a nation, bemoan the inequitable educational outcomes between Black and Latino students and their White peers, we often "behave as though we are unaware of -or insensitive to-the equally substantial inequalities in access to educational opportunity that occur form preschool through elementary and secondary education, into college and beyond" (p. 318).

Fifty years after Brown v. Board of Education, there remain large gaps in academic achievement between children of color and White students (Darling-Hammond, 2007). Addressing the achievement gap in America is critical to ensuring our nation's prosperity. It is estimated that by 2050, the population of the United States will increase by fifty percent; ninety percent of which will be accounted for by minorities (Vanneman, Hamilton, Anderson, Rahman, \& National Center for Education, 2009). In less than fifty years, our workforce will be comprised of "groups that are over represented among low achievers, and under represented among high achievers" (Ferguson, 2005, p. 4). The social stability of our nation depends heavily on how dedicated we are to the pursuit of academic equity for students of color (Ferguson, 2005). Our nation cannot be successful in meeting the needs of the new economy if our students do not encounter much more rigorous work in school, and many argue that schools cannot improve unless the accomplishments (or learning gaps) of their students become public knowledge (DarlingHammond, 2007).

It is also of great importance that we evaluate the achievement gap in order to ensure students of color are afforded the same rights as the majority population. Our nation is based on the belief that all men and women are created equal, yet the educational system says otherwise. 
As educators, we say we are teaching all children; however, statistics show that young Black students are only half as likely and Latino students only one-third as likely to earn a bachelor's degree as White students (Haycock, 2001).

Furthermore, in order for a democracy to thrive in an atmosphere that requires a welleducated citizenry, it must create an educational system that can guarantee its students the right to learn. According to Darlington-Hammond (2007), many people of color do not receive the education they need in order to compete in a labor market that increasingly demands higher levels of education from its citizens. Nearly $70 \%$ of jobs in the United States today require specialized skills and training beyond high school; if our students of color are not getting the same educational opportunities in our school systems, how can they compete in a job market as competitive as the one operating in the United States? If our nation prides itself on its attempt to keep jobs in the United States rather than outsourcing them overseas, we must ensure our citizens have the right to an education that prepares them for the rigors of employment. While the United States struggles to fill its high-tech jobs with individuals educated overseas, many of its own citizens are struggling to find employment.

In order to address these inequities, educators must ask themselves: Why are our Black and Latino students not performing at the same level of proficiency as our White students? Silence among educators when it comes to discussing knowledge gaps between students of color only perpetuates the problem (Singleton \& Linton, 2006). As educators, we must begin to ask the tough question: How am I contributing to the widening of the achievement gap? By beginning to look at ones teaching introspectively, I believe educators can begin to transform their learning in a way that will lead to improved student achievement. 


\section{Congratulations!}

You have decided to do a cycle of inquiry in order to ensure you continue to teach equitably and efficiently. The process may seem overwhelming at first, but realize that as you get comfortable with the ins and outs of a cycle of inquiry, the process will become part of your practice. You will notice how you talk about students will be different, how you plan your lessons will be more informed, and the success of your students will increase!

Below is a brief outline of the process you are about to begin - the following sections will go into more detail regarding the process of implementing a cycle of inquiry in order to begin to close the racial achievement gap in your classroom.

\section{CYCLE PROCESS}

1. Determine if you will be participating in this work as a school, a grade level, or as an individual

2. Identify potential focal students

3. Determine who you will select as your focal students

4. Interview and get to know your focal students inside and out

5. Determine a focus for your inquiry into practice

6. Determine your measurable goals

7. Create an action plan

8. Collect and analyze data

9. Determine your next steps

10. Start the process again!

Once you have gone through this process once or twice, it will become second nature. You will find you are asking all the right questions in every subject even if it is not your focus subject area for your current cycle of inquiry. 
How Does a Cycle of Inquiry Support My Work with Common Core Student Learning and Growth Goals? With the passage of Senate Bill 290 (SB290) in 2011 and Oregon's Elementary and Secondary Education Act (ESEA)'s Flexibility Waiver in 2012, Oregon has rededicated itself to meeting the needs of all of Oregon's students through educator professional growth and support. As a result, educators are engaging in collaborative discussions regarding student achievement and how to best meet the needs of their students.

As part of the evaluation process, educators are now expected to specifically address student learning and growth through the collection of summative and formative assessment data. Based on SB290 and the ESEA waiver, teacher evaluations now require multiple measures of performance-including impact on student learning and growth.

Student Learning and Growth (SLG) goals typically focus on a group of students' growth throughout the span of a school year. This handbook will support educators in monitoring their students' growth regularly throughout the year - as a result of participating in this process, teachers will know exactly where their students are in relation to their SLG goals at any given moment.

The steps for setting SLG goals are very similar to the steps taken in a cycle of inquiry. Participating in a cycle of inquiry can be compared to setting smaller, more specific SLGs throughout the year.

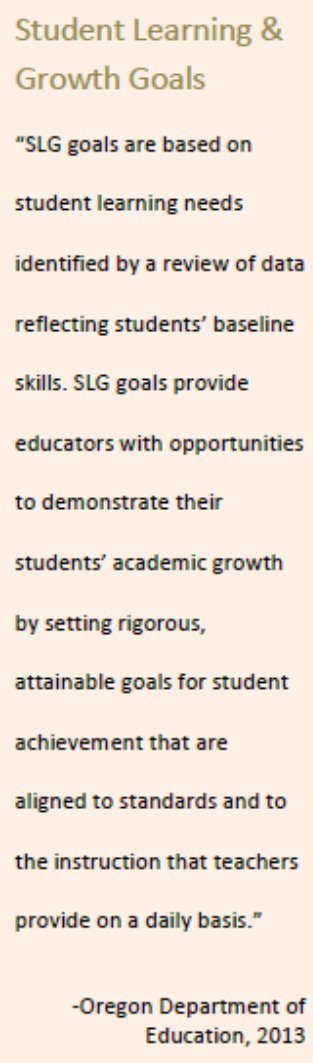




\section{Getting Started}

How Do We Determine Our Focal Students?

When identifying focal students, you need to determine if your cycle of inquiry will have school-wide participation or if you will be designing your cycle of inquiry for your grade level team or your

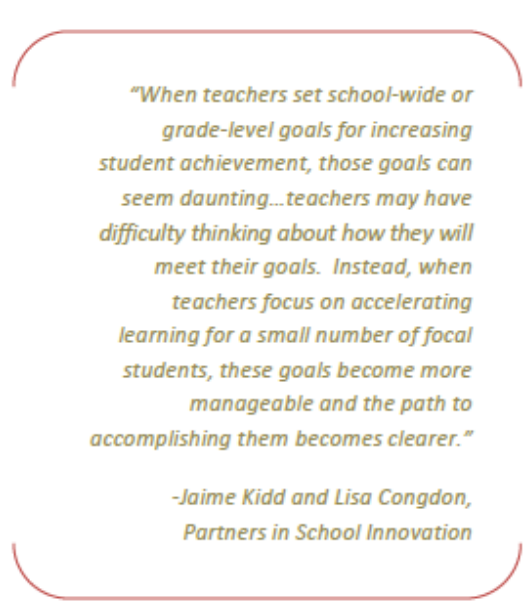

$$
\begin{aligned}
& \text { classroom individually. } \\
& \text { The process for } \\
& \text { determining your focal } \\
& \text { students will vary } \\
& \text { depending on the } \\
& \text { groups participating. } \\
& \text { For instance, if your } \\
& \text { entire school is } \\
& \text { participating, it makes } \\
& \text { sense to choose focal } \\
& \text { students from the } \\
& \text { group that shows an }
\end{aligned}
$$

Focal Students

- Students who

have Limited

Progress Toward

Standard and/or

are Progressing

Toward Standard

- Students of color

- Teachers explicitly plan their lessons with these students in mind

achievement gap in your school data versus grade level data.

However, if your grade level team is the only team participating in your cycle of inquiry, looking at grade level data to determine your focal group makes the most sense.

\section{Focal Students}

Focal students are students "who are performing below grade level standard. Most often, focal students are representative of the larger achievement and opportunity gaps in the school" (Kidd \& Congdon, 2007, p. 1). Teachers observe these students, interview these students, and plan their cycles of inquiry with these students in 
mind. If teachers are designing their lessons to meet the needs of their focal students (and measuring the results), they will teach in a more rigorous fashion, and a ripple effect will occur. Because they focus intently on the learning of their focal students, the rest of their students will also benefit from this planning (Kidd \& Congdon, 2007). "By setting specific goals around focal student mastery of standards and measuring progress toward these goals on a daily, weekly and monthly basis, teachers gather concrete evidence about the effectiveness of their instruction and how to make adjustments to better serve their students" (p. 1).

The purpose of choosing focal students is to explicitly plan lessons to motivate and engage your students of color. When choosing focal students, it makes sense to choose students who have demonstrated limited progress toward standard and/or are progressing toward standard.

Performance Levels and Achievement Zones

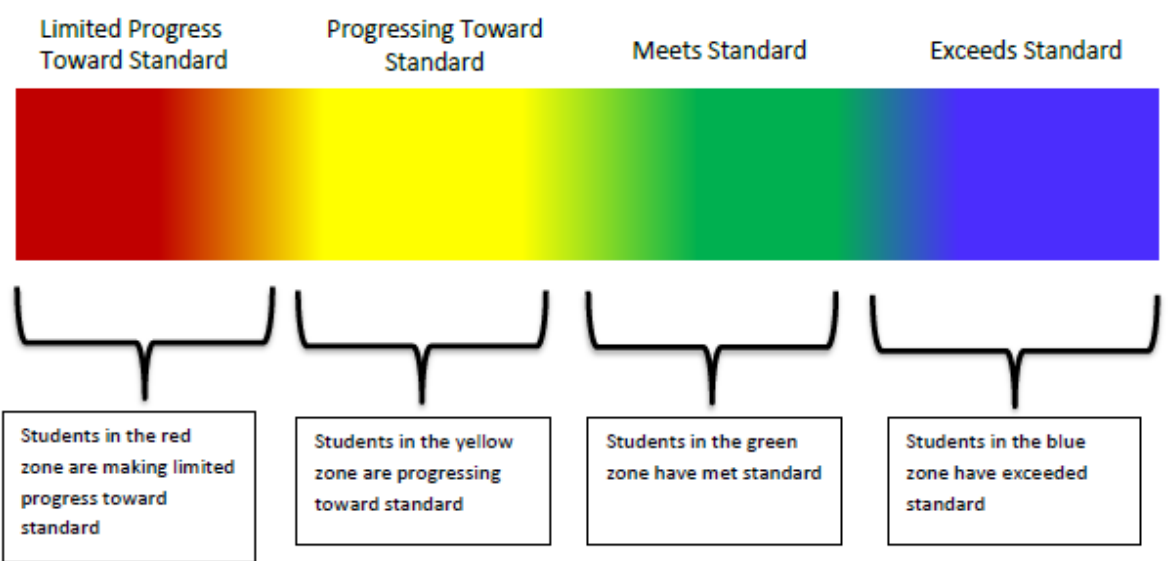

\section{Limited Progress Toward Standard-The Red Zone}

Students in the red zone are those students identified as having demonstrated limited progress toward standard, and are significantly below grade level. While students in the red zone may not meet standard at the conclusion of your cycle of inquiry, it is highly likely that, if chosen as 
focal students, they will see significant growth within their zone and possibly move into the yellow zone-progressing toward standard.

Progressing Toward Standard-The Yellow Zone

Students in the yellow zone are students who are below grade level but are progressing toward standard. Yellow zone students are students who have not yet met standard but could reasonably do so if they were given focused instruction in the areas where they have academic gaps.

Meets Standard-The Green Zone

Students in the green zone are at grade level and have met standard. They, too, will benefit from the rigorous and engaging lessons you are planning for your focal students, but most often will not become focal students because they have already demonstrated grade level achievement. However, some teachers might find it beneficial to focus on students in the green zone who are not showing the academic growth the teacher feels they are capable of.

Exceeds Standard-The Blue Zone

Students who have exceeded standard are in the blue zone. Blue zone students aren't typically selected as focal students because they have already shown mastery of the content; however, they still require engaging lessons in order to maintain their academic achievement. It is important that blue zone students still show growth academically, so technically, if a teacher wanted to select a blue zone student as a focal student, that would be acceptable. However, remember, if closing the academic achievement gap for students of color is the primary reason for implementing the strategies in this handbook, it would be more advantageous to choose focal students in the red and/or yellow zone. 


\section{Tools for Identifying Focal Students}

\section{Using State Assessment Data}

It is helpful to have a system to quickly scan a list of students to determine if they are eligible to become focal students based on their state wide assessment data and group membership.

Using the tool provided in the handouts section of this handbook, you can easily enter a class of students and their test scores and color code them (according to performance level) by subject area. Once you have completed the assessment tool, it will be easy to identify which students fit into the focal group by group based on group membership and academic performance level.

Table 1: Identifying Focal Students

\begin{tabular}{|c|c|c|c|c|}
\hline Student Name & $\begin{array}{l}\text { Focal } \\
\text { Group } \\
\text { Reading }\end{array}$ & $\begin{array}{l}\text { Focal } \\
\text { Group } \\
\text { Math }\end{array}$ & $\begin{array}{l}\text { Reading Assessment } \\
\text { (Passing score 221) }\end{array}$ & $\begin{array}{l}\text { Math Assessment } \\
\text { (Passing score 225) }\end{array}$ \\
\hline Holly & $x$ & & 219 & 231 \\
\hline jaime & & & 221 & 224 \\
\hline Edgar & & & 218 & 224 \\
\hline Max & & & 240 & 244 \\
\hline Alexander & & & 229 & 226 \\
\hline Ken'́ & & & 211 & 220 \\
\hline Mates & & & 225 & 229 \\
\hline Ahmad & $x$ & $x$ & 217 & 224 \\
\hline Marx & & $x$ & 225 & 220 \\
\hline olivia & & & 229 & 228 \\
\hline Abigail & & & 198 & 199 \\
\hline Oskear & & & 231 & 224 \\
\hline Victoria & & & 214 & 220 \\
\hline$\omega z$ & & & 226 & 22.5 \\
\hline Tran & & & 202 & 211 \\
\hline Javier & & & 219 & 216 \\
\hline Jessica & $x$ & & 220 & 223 \\
\hline Andy & & $x$ & 221 & 224 \\
\hline Tiffany & $x$ & & 220 & 2.25 \\
\hline Erian & & & 243 & 231 \\
\hline carol & & & 216 & 223 \\
\hline simon & $x$ & & 2.34 & 241 \\
\hline Keesina & $x$ & $x$ & 219 & 223 \\
\hline Silas & $x$ & & 217 & 209 \\
\hline
\end{tabular}

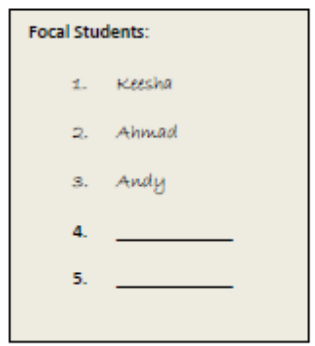


Looking at the example represented in Table 1, Edgar would be a good candidate as a focal student in the area of reading and math because he falls within the yellow zone in both subjects; however, Oskar would be a candidate in reading, but has already met standard in math, so he would not be eligible for focal student status in mathematics. Remember, when filling out the Identifying Focal Students tool, it is imperative that you accurately label the students as being a member of the focal group by placing an " $x$ " in the focal group column.

Using Formative Assessment Data

While state testing data is very important and informative, it does not tell you how well your students are doing today. Therefore, formative assessment data becomes a very important tool for identifying your focal students as well as monitoring their progress throughout your cycles of inquiry.

It is important to give a pre-assessment in order to get a clear picture of how your focal students are doing on the particular standard on which you or your team have decided to focus your first cycle of inquiry. As part of your cycle, you will design and administer a pretest prior to starting your cycle of inquiry as well as formative assessments throughout your cycle in order to monitor student understanding. Your formative assessment data can be organized in a similar way as your state testing data; highlight exceeding scores blue, meeting scores with green, progressing toward standard scores with yellow, and limited progress toward standard with red. This way, you can get an idea of how your students are doing in a quick glance.

\section{What Happens After I Have Selected My Focal Students?}

Once you have selected your focal students for this cycle of inquiry, you will begin the process of getting to know your focal students inside and out. You will learn if they have a fixed or growth mindset (Dweck, 2006), build stronger relationships with your focal students in order to design lessons that are aimed at motivating and engaging them. The following sections will discuss determining if your focal students have a fixed mindset or a growth mindset, strategies for getting to know your focal students better, strategies for teaching equitably as well as quick formative assessment strategies, and the step-by-step process for participating in a cycle of inquiry. 


\section{Do Your Focal Students Believe They Can Learn?}

Before beginning to plan your cycles of inquiry explicitly designed to

meet the academic needs of your focal students, it is important to

understand what your students believe regarding intelligence. Some

students come to us with the belief they can learn, and others

believe intelligence is something you are born with - not something

you get; and therefore, do not believe they can achieve academically

(Dweck, 2006). Students who believe intelligence is something they can improve have growth mindset, and those who feel intelligence is something you are born with and cannot improve upon have a fixed mindset.

\section{Fixed Mindset}

Students with a fixed mindset:

- Avoid challenge-do not want to make mistakes or fail

- Try to hide mistakes rather than fix them

- Believe if they were intelligent, they wouldn't have to try hard

- Do not deal well with frustration-sometimes they give up or result to cheating in order to appear as though they understand the material

- Worry about whether people think they are smart or not

\section{Growth Mindset}

Students with a growth mindset:

- Believe their effort will help increase their intelligence

- Do not give up when faced with challenges

\section{Mindsets}

Students with a fixed

mindset believe

intelligence is something

you are born with-either you are smart or you are

not. They don't believe

they can strengthen their

intellect.

Students with a growth

mindset believe their

intelligence is not

predetermined, but can

grow as they are exposed

to new information. 
- Look for new learning strategies in order to understand new information

In working to close achievement gaps, educators need to ensure their students are working from a growth mindset-that is, they believe they can build intelligence and learn. In order to determine if your students have fixed or growth mindsets, it would be beneficial to give students the following mindset quiz.

The following quiz can be given to students in order to determine if your students have a fixed or growth mindset.

\section{Do Your Students Have a Fixed Mindset or a Growth Mindset?}

About $40 \%$ of students have a Growth Mindset, which means they don't see their intelligence as fixed. Consequently, they are not afraid of challenge, they welcome feedback, and they react to failure by trying harder.

Another $40 \%$ have a Fixed Mindset, which means they see intelligence as a fixed entity (they feel they were born bright or not very bright and nothing that happens in school is going to change this). Consequently, they don't like challenge and they fear failure, so they will not take risks, and they like easy tasks (and lots of praise for doing them well). They also tend to conform to the low aspirations of their peers.

To Use The Quiz:

1. Have students complete the quiz

2. Add up the score for the first three answers only

3. Divide the total by three

Results:

- A score of 3 or less means the student has a fixed mindset

- A score of 4 or more means the student has a growth mindset

- A score of 3.3 or 3.7 means they are borderline

Note. From http://growthmindseteaz.org/Testintelligence.html. Reproduced with permission. 
Name

Date

\section{Mindset Quiz}

- Read the sentences below and circle the answer you agree with most. You may only circle one answer. There are no right or wrong answers.

1. You are born with a certain amount of intelligence, and you really can't do much to change it.

$\begin{array}{cccccc}1 & & 3 & & 6 \\ \text { Strongly } & 2 & \text { Mostly } & \text { Mostly } & 5 & \text { Strongly } \\ \text { Agree } & \text { Agree } & \text { Agree } & \text { Disagree } & \text { Disagree } & \text { Disagree }\end{array}$

2. Your intelligence is something about you that you can't change.

$\begin{array}{cccccc}1 & & 3 & 4 & & 6 \\ \text { Strongly } & 2 & \text { Mostly } & \text { Mostly } & 5 & \text { Strongly } \\ \text { Agree } & \text { Agree } & \text { Agree } & \text { Disagree } & \text { Disagree } & \text { Disagree }\end{array}$

3. You can learn new things, but you can't really change your intelligence.

\begin{tabular}{|c|c|c|c|c|c|}
\hline $\begin{array}{c}1 \\
\text { Strongly } \\
\text { Agree }\end{array}$ & $\begin{array}{c}2 \\
\text { Agree }\end{array}$ & $\begin{array}{c}3 \\
\text { Mostly } \\
\text { Agree }\end{array}$ & $\begin{array}{c}4 \\
\text { Mostly }\end{array}$ & $\begin{array}{c}5 \\
\text { Disagree }\end{array}$ & $\begin{array}{c}6 \\
\text { Strongly } \\
\text { Disagree }\end{array}$ \\
\hline
\end{tabular}

4. No matter who you are, you can change your intelligence.

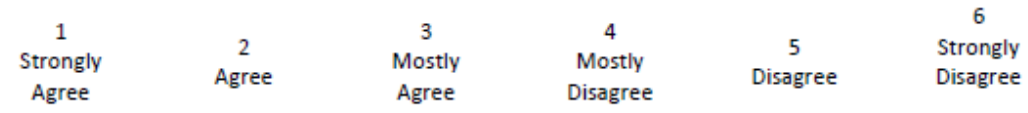

5. You can always greatly change how intelligent you are.

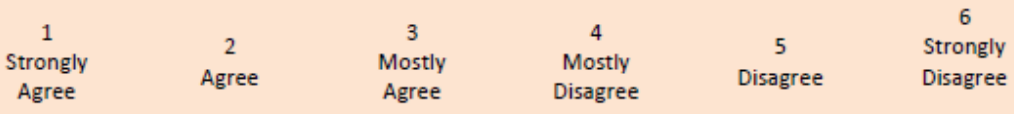

6. No matter how intelligent you are, you can always change it quite a bit.

\begin{tabular}{|c|c|c|c|c|c|}
\hline $\begin{array}{c}1 \\
\text { Strongly } \\
\text { Agree }\end{array}$ & $\begin{array}{c}2 \\
\text { Agree }\end{array}$ & $\begin{array}{c}3 \\
\text { Mostly } \\
\text { Agree }\end{array}$ & $\begin{array}{c}4 \\
\text { Mostly }\end{array}$ & $\begin{array}{c}5 \\
\text { Disagree }\end{array}$ & $\begin{array}{c}6 \\
\text { Strongly } \\
\text { Disagree }\end{array}$ \\
\hline
\end{tabular}

Note. From http://growthmindseteaz.org/Testintelligence.html. Reproduced with permission. 
What Do I Do With the Mindset Quiz Results?

Once you have scored your students' mindset quizzes, you will know whether or not your students are operating from a fixed mindset or a growth mindset. It is important that, at this time, you begin to support your students who have fixed

The growth mindset teacher: mindsets in beginning to view intelligence as something

"I am not interested in that is not fixed, but rather, as something that can grow.

judging how good your work

is; I am interested in the

quality of your learning."

Use Statements that Encourage a Growth

Mindset

-Carol Dweck (2006)

In order to foster a growth mindset with students, refrain

from praising the person (you're so smart!), and begin to

praise the process (Wow! You spent a lot of time working on that problem!) (Dweck, 2006).

Students with fixed mindsets are often preoccupied with perfection, speed, and competition.

Therefore, follow these rules as you give feedback to avoid falling into the trap of using fixed mindset feedback with your students:

- Do not use the word perfect

- Avoid praising students for the speed of their work

- Avoid comparing a students work to that of their peers

- Avoid discussion of grades

In order to foster a growth mindset, praise a student's process, their effort, and their determination. If students realize their worth is not associated with a score, they are likely to begin to take risks and engage in challenging activities-activities they may have avoided previously as a result of a fixed mindset.

In addition to supporting your students with developing a growth mindset, taking the time to build strong relationships with them will certainly support your efforts in beginning to close the achievement gap in your classroom. The following section will provide several strategies you can use in order to build strong relationships with your focal students. 


\section{Further Resources}

- Ted Talks on Fixed and Growth Mindset: The following Ted Talks highlights the differences between fixed and growth mindsets and how they manifest themselves in the classroom. http://www.youtube.com/watch?v=pN34FNbOKXc

- Mindset: The New Psychology of Success (Dweck, 2006): This book discusses the psychology of success and how it pertains to growth and fixed mindsets. You can also visit the website dedicated to Dweck's work at: http://mindsetonline.com/ 


\section{Strategies for Building Relationships with Your Focal Students}

One of the most effective ways to motivate students who have traditionally been disengaged is through building strong, positive relationships with them. Through the development of positive relationships, educators can begin to better understand what motivates their students. Once motivating factors have been determined, it is easier to plan lessons that grab the attention of students and hold it-thus, seeing an increase in engagement and achievement.

This section will focus on several easy strategies teachers can use to build positive relationships with their students.

Interview Your Students

One of the easiest ways to get to know students is to interview them (Milner, 2011). One of the most common reasons educators don't take the time to interview their students is time;

however, interviews do not need to be formal, sit-down events. Teachers can interview their students on the way to recess, while they work with them oneon-one, or as students wait in line in the cafeteria. Information gathered in interviews can then be incorporated into lessons in order to encourage engagement for that particular student. Common interview questions might include:

- What do you like to do on the weekend?

- If you could travel anywhere, where would it be?

- What are you most proud of?

- What is your favorite television program or movie?

- What career would you like to have as an adult?

- Who is your favorite singer? What is your favorite song?

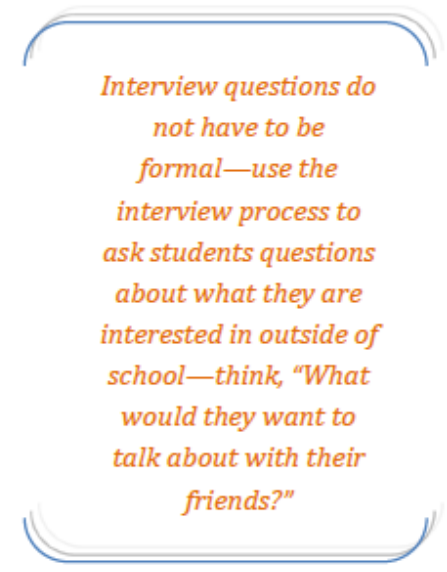

- What sports do you like?

Each of the questions above could be asked, answered, and mentally recorded by the teacher in a matter of minutes-giving the teacher information about what they might incorporate into future lessons in order to engage that particular student. 
Give Assignments that Highlight Students' Experiences and Interests

Incorporating students' interests into classroom assignments is an easy way to foster and strengthen relationships with your students

(Milner, 2011). While there are countless ways of doing this, Milner suggests the following:

- Math: Instead of arbitrarily creating scenarios to use in problem solving, incorporate your students' interests. For example, one might have students determine how many vans will be necessary to get to the Rhianna concert if each van carries 8 people, and 76 people are planning to attend.

- Reading: Incorporate pieces of literature or articles that are about topics to which your students can relate-for example, read literature like The Circuit, a novel that describes the author's experiences working in agriculture while growing up in the United States illegally, or House on Mango Street by Sandra Cisneros. Read literature where the main characters have similar experiences and struggles as your students of color.

- Writing: Allow students to write about their own experiences or allow them to write persuasive pieces on subjects they feel passionately about. Encourage them to pick writing topics that might spur discussion amongst students, opening up the opportunity for authentic dialogue.

- Social Studies: Allow students to do culture based projects or family history projects as often as possible. When studying main-stream topics, include discussions about those not traditionally discussed (i.e., if discussing the American

5 Easy Ways to

Connect with Your

Students (Milner, 2011)

1. Interview Your Students

2. Give Assignments that Highlight Students'

Experiences and

Interests

3. Allow Students to be the Center of Attention

4. Attend Extra-

Curricular

Activities

5. Visit Your

Students'

Communities 
Revolution, take on the perspective of Native Americans or white women, etc.)

Allow Students to be the Center of Attention

often, students who are not at grade level disappear in the classroom. They do not participate in group discussions nor offer their thoughts to their peers. It is important for educators to give ample opportunities for students to be the center of attention. Allow students to voice their opinions regarding current events, literature, or the strategies they used to solve a particular problem. Giving students the floor and allowing the discussion to evolve based on their understanding or take on a particular topic allows them to express themselves authentically. Incorporate topics you know will engage your focal students, and encourage them to join the discussion by referring to them as experts on the topic. By fostering discussion and debate in your classroom, you are permitting students to take center stage which allows true teachable moments to arise.

Leave a Note

An effective strategy for building connections with students is to leave them a note on their

"Something I've done before is I'll take an index card, and I'll write a little positive note to a student and tuck it inside their desk. Later, when they find it, the other kids will be like, 'What's that? I want one!' And they love it, and they keep it!" $-5^{\text {th }}$ Grade Teacher

desk. It doesn't have to be long; rather, just a quick note to let them know how proud you are of them, or how you have noticed the hard work they have been doing in a particular subject. The note can be written on an index card and then folded in half or can be written on a post-it that you fold in half. Once you have written the note, place it in a place where the student is sure to find it (i.e., atop of their desk, on their seat, etc.). It is likely the students will collect and keep the notes you write them throughout the school year. It is an easy, yet very meaningful, way to connect with your students and let them know you recognize their efforts.

Attend Students' Extra-Curricular Activities

Think back to your youth and how excited you were to see your teacher outside the classroom. Now imagine how intensified that excitement is when you knew your teacher had come to see 
you doing something you loved to do. Attending extra-curricular events is an easy way to show a student you are invested in their wellbeing both in and out of the classroom.

Make a Positive Phone Call Home

Positive feedback is one of the easiest ways to build relationships with your students. Taking the time to call a student's caretaker(s) in order to brag about the

"Parents are always surprised when I call home with positive student's accomplishments in the classroom can build news! They are always thankful, confidence and trust with your students. The call does not have to be about academics - take the time to discuss a good decision the student made, how the student helped a classmate, or how the student took and the students come to school the next day and tell the other kids all about it!" $-5^{\text {th }}$ Grade Teacher extra care to do their very best work on an assignment.

Visit Your Students' Communities Show your students you are interested in their lives by visiting their community. Milner (2011) argues that by visiting the communities in which students live, educators are able to experience first-hand the lives of their students outside the learning community. Go grocery shopping in your students' community, see a movie, or take a walk and see who you run into.

Hang out With Your Students Outside of the Classroom This is possibly one of the easiest ways to build relationships with your students, and it's easy! Taking the time to hang out with your students in a non-academic setting gives you the opportunity to talk with them and get to know them as individuals. While walking the track, shooting hoops, or swinging on the swings, you can begin to bond with students who may not readily bond over academics. It gives them an opportunity to see you as a person as well. Seeing you have fun outside of class will allow them to understand what makes you tick. It's a win-win!

Conduct Morning Meetings

Many teachers attribute the sense of community in their classrooms to the morning meetings they facilitate. Morning meetings give educators an opportunity to see what students are 
feeling confident about and what they are worried about. In addition, it gives students the stage and allows them to be the center of attention. One strategy for organizing morning meetings is to have students sit in a circle and take turns answering a specific question such as , "I am feeling confident at , but I think I need to work on

." This way, teachers give students an opportunity to identify the areas where they are confident and those where they need support.

Admit When You are Wrong

Admitting when you are wrong goes a long way. Students need to recognize that you are human and that you make mistakes. By modeling ownership of your mistakes, you are sending the message to your students that it is okay for them to make mistakes. Often, educators think they can't admit when they've made a mistake in fear of losing credibility with their students; however, I would argue that admitting your shortcomings to your students makes you more human, and, therefore, more relatable.

\section{Further Resources}

- Building Relationships with Your Students (K-12) Aurora Public Schools. This site includes activities, ice breakers, and assignments, such as Getting to Know You Bingo, Morning Check-In, Bio Poems and Random Questions to foster relationships with students: http://equity.aurorak12.org/wp-content/uploads/sites/49/2012/04/BuildingRelationships-Handout.pdf

- Building Positive Teacher-Child Relationships. This site is a PowerPoint presentation which includes activities to help build relationships with students. http://csefel.vanderbilt.edu/kits/wwbtk12.pdf

- The Morning Meeting Book by Roxann Kriete and Lynn Bechtel (2002) gives educators step-by-step instructions on setting up and managing morning meetings in their classrooms. 


\section{Equitable Teaching Practices}

\section{Equity is NOT Equality}

When it comes to teaching, equality is not equity. It is important that, while educators strive to close the achievement gap, they realize equal treatment of students leads to maintaining the status-quo. Equitable teaching leads to increased achievement for students who are below grade level.

Equality

Equality suggests everyone is treated the same. In the classroom, this means all students are given the same learning opportunities in the same way. Equality only works when everyone is starting at the same place (i.e., the same grade level). If all the students in a classroom are not starting with the same skill sets and abilities, then equal treatment of those students will often result in the widening of achievement gaps.

\section{Equity}

Equity is when everyone is given the same access to learning. Students who are performing below grade level are given different (and sometimes more) opportunities to master standards (i.e., small group instruction, pre-teach/re-teach, etc.).

In order to close the achievement gap, teachers need to teach equitably. This handbook will help you do that.
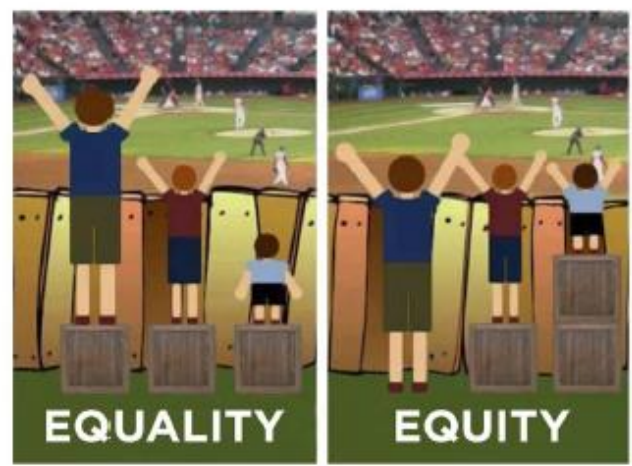
Equitable Teaching Strategies

There are hundreds of equitable teaching practices teachers can use in their classrooms to promote learning for all students. Montgomery County Schools has authored a lengthy list of equitable teaching practices. The following are some of the easiest strategies educators can use to build positive relationships and engage all of their students. For more equitable teaching strategies, the entire document can be downloaded at:

http://www.pps.k12.or.us/schools/gray/files/bmadison/Maryland Equitable Practices.pdf

Welcome Students by Name as They Enter the Classroom

While this seems too easy to be true, taking the time to greet students by name as they enter your classroom shows them you both respect and care about them. While this might be the easiest strategy of all, it takes effort. Too often teachers find themselves organizing the last details of their lessons as students enter their classrooms, thus not allowing for a meaningful greeting. In order to ensure you have the opportunity to greet your students as they come into your room, be sure to have all your planning done before the bell rings!

Promote Interpersonal Discussions In order to support all students in

participating in classroom discussions, it is helpful to follow a semi-structured protocol.

- Ask Question

- Allow for Private Think Time

- Partner Share

- Random Response

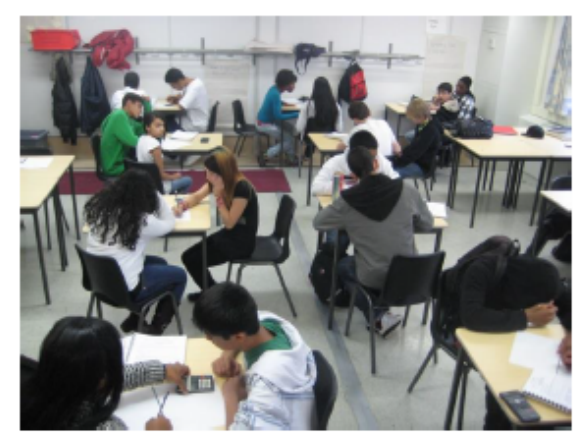

Think Time

Think time is the time an educator allows students to think between asking a question and taking responses from students. Often, teachers will call on the first students who raise their hands, which inhibit others from thinking the answer through. If students know someone else will get the answer before they do, they often disengage. In order to ensure all students are 
given an equitable opportunity to think, provide at least 20 seconds of wait time before taking responses.

Partner Share

In addition to think time, students often need to talk their thoughts through with a peer before offering their insights to the entire classroom. Incorporating partner sharing into your protocol allows students to think through their response as they share with a peer.

Organizing partner share time is essential. The biggest mistake educators make is to tell their students to turn and talk to their neighbor without giving any training on how to do so. Too often, partner share time is wasted on one person doing all the talking. In order to ensure both participants in the partner share participate, I suggest using the following protocol:

- Students turn to face one another

- The student who is youngest (could also be the student with the most siblings, the student closest to the door, the student on

Think-Pair-Share

1. Students are given private think time

2. Students face one another

3. One student shares while the other listens

4. Reverse roles the left, etc.) shares first

- While the first student is sharing (30 seconds), the second student is actively listening-not talking! They nod, smile, and make eye contact to show they are engaged, but they are not allowed to interrupt or agree or disagree with the student talking.

- Once the first student's 30 seconds is complete, the second student gets their 30 seconds to share their thoughts. Again, the listener is not allowed to talk in any capacity

- Once both students have had 30 seconds to share their thoughts, give the team 30 more seconds to talk back and forth about their opinions. At this point, they can agree with one 
another, disagree with one another, ask each other questions, and so on.

Following Think Time and Partner Share, students feel prepared and confident to participate in discussions. It is still important, however, that you not only call on those raising their hands.

Everyone needs to be accountable-that means they might get called on even when their hand is not raised.

Further Resources:

- Videos describing Think Pair Share:

- The following videos describe the Think Pair Share protocol giving step-by-step instructions on how to incorporate it you're your classroom

- http://www.youtube.com/watch?v=YGCyk QaCOI

- http://www.youtube.com/watch?v=-9AWNI-A-34

Use Random Response Strategies

In addition to wait time and partner share, it is important all students have a voice in classroom discussions; that means, you can't only call on students raising their hand. In order to ensure all students are participating, you might employ one of the following strategies:

- Equity Sticks: Put each student's name on a stick. Pull a stick after giving students ample time to think privately and time to partner share to think through their response. Remember, not all students are treated equally in your classroom. If you have students you want to engage and motivate to participate in your discussions, you might consider putting those students' names on more than one stick-that way, they will get ample opportunities to share their thinking.

- Numbered Heads Together: Numbered heads is a cooperative learning strategy that supports students in actively participating in group discussion in order to answer a particular question. Students know, when using the numbered heads together protocol, that after the small group discussion, one member of the team is going to be responsible for answering for the group. Therefore, it is advantageous for all members of the group to work together to ensure everyone understands the material. 
- Divide students into groups of 3 or 4

- Assign each student a number $(1,2,3$, or 4$)$

- Pose a question

- All members of the group discuss the question and agree upon an answer

- Call on a particular number to answer the question

\section{Further Resources:}

- The following video shows a classroom participating in the Numbered Heads Together protocol: http://www.youtube.com/watch?v=ADmXhDuHpD4

Get Multiple Perspectives

So often in an attempt to save time, educators take the first right answer and move on. In order to encourage equitable teaching practices, it is important teachers take the time to get more than one perspective. The next time you ask a question, try employing one or more of the following to get more than one perspective:

- That's one idea, does anyone have another idea?

- Does anyone have a different opinion?

- Did anyone get a different answer?

Allowing for more than one perspective lets students know there isn't always a single correct answer; often, there are several perspectives that can be correct.

Ask High-Order Questions of All Students

Often, educators ask high-order questions of their higher students and reserve easier recall or yes/no questions for their lower achieving students. In order to ensure all students are getting equitable opportunities to share their thinking, ask higher-order questions of all of your students. It is important to ensure you are giving all students the opportunity to answer questions that require critical thinking. Types of higher-order questions:

- Why do you think happened?

- What could you have done differently to get a different outcome? 
- What would you have done in this situation? Why?

- How are and alike? How are they different?

- What caused to occur?

Further Resources

- At the following website, you can find a list of Costa's Sentence Starters for Higher-

Order Questioning

http://www.nscsd.org/webpages/iennisullivan/files/levels\%20of\%20questioning(1).pdf

- At the following website, you can find a list of Bloom's Questions Starters for HigherOrder Thinking:

http://webcache.googleusercontent.com/search?q=cache:AOH7 pYANAMJ:www.nscsd. org/webpages/jennisullivan/files/blooms-questionstarters.docx $+\& c d=2 \& h l=e n \& c t=c l n k \& g l=u s$

Once relationships have been built and teaching strategies formulated, it is time to begin planning lessons that will motivate and engage your focal students. This section will walk you through, step-by-step, the process of participating in a cycle of inquiry.

\section{Further Resources}

- Montgomery County Public Schools provides a series of "Short Takes" or videos describing and modeling equitable teaching practices such as using students' real life experiences to connect to learning, answering questions that foster critical thinking, strategies for assessing students' prior knowledge, etc. The Short Takes can be found at the following website:

http://www.montgomeryschoolsmd.org/departments/development/resources/ecp/ecp 11-20.shtm

- The following site leads to NEA's CARE guide 2011, which includes specific teaching strategies and activities designed to help close the achievement gap: http://www.nea.org/assets/docs/CAREguide2011.pdf 
- The framework found at this website discusses the causes of equity gaps, and resources leading to the implementation of strategies/best practices to begin to close the achievement gap:

https://www.ocps.net/cs/services/initiatives/Documents/Strategies\%20Document.pdf

- Multi-Cultural Teaching Strategies from the Center for Research on Learning and Teaching: http://www.crlt.umich.edu/tstrategies/tsmdt

- At the following site, the Metropolitan Center for Urban Education lists strategies for Culturally Responsive classroom management, understanding one's own cultural background, understanding the background of your students, and strategies for building caring classrooms:

http://steinhardt.nyu.edu/scmsAdmin/uploads/005/121/Culturally\%20Responsive $\% 20 \mathrm{C}$ lassroom $\% 20 \mathrm{Mgmt} \% 20 \mathrm{Strat} 2 . \mathrm{pdf}$ 


\section{Formative Assessment Strategies}

Formative assessment is essential to monitoring student learning and growth throughout a cycle of inquiry. While summative assessment data serves to determine how much students have learned at the end of an academic unit, formative assessment is designed to very

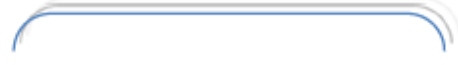

"Formative Assessment allows me to see where my students are right now and helps me to

determine my next steps

$$
\text { in instruction." }
$$$$
-5^{\text {th }} \text { Grade Teacher }
$$

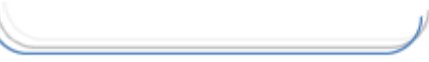

quickly assess students in

order to determine their

level of understanding

immediately following a

lesson. Formative

assessment is meant to

drive instruction; that is,

the results you get on today's formative assessment will determine

what you teach tomorrow. If educators take the time to do

formative assessments during their cycles of inquiry, they will not be

surprised by their summative assessment results - they will already

know exactly where every student is academically, and they will have

already made plans to support students in need of further

instruction.

Formative assessments are meant to provide instructors with a snapshot of what their students understand in the moment, it is not meant to provide hours of grading. Instead, educators should be able to look at the formative assessment and know almost immediately if their students understand the standard.

This section will introduce several quick and easy formative assessment strategies-all of which can be done in minutes.

\section{Keeping Track of}

Formative

Assessment Data

Having a clipboard with a

data collection sheet

handy at all times is

helpful in keeping track of

formative assessment

data. This way, as your

students hold up

individual whiteboards or

red, yellow, or green

cards, you can note who

does not understand the

content immediately. 
Three Dos and A Don't

Three Dos and A Don't is a great way to dig deeper into how well your students understand a particular procedure or process. Students are asked to write three things they would do in a particular process and three things they would not do.

Example: Write three Dos and A Don't for adding and subtracting fractions.

When adding and subtracting fractions, DO

DO and DO but, DON'T

When adding and subtracting fractions, $\underline{D O}$ find a common denominator, $\underline{D O}$ add the numerators together once you have a common denominator, and $\underline{D O}$ reduce, but $\underline{D O N^{\prime} T}$ add the denominators together.

Notecards/Index Cards

Notecards can be used in multiple ways. They can be used to answer a single question or used to have students explain what they understand and what they are still confused about. The idea of using a notecard is to ask questions or problems that can be answered quickly.

- Write the problem or question students are expected to answer on the board, and give the students $3-5$ minutes to answer the question on their notecard. For example, one could write:

Example: Use an area model to show the sum of one fourth and three eighths.

- Have students write one thing they understand on the front of their card and one thing they are confused about on the other side.

Example: On the front of your notecard, write one thing you understand regarding the causes of the American Revolution. On the back, write one thing you are unsure about in regard to the causes of the American Revolution. 
Individual Dry Erase Boards

Give each student an individual dry erase board and a dry erase

marker. Ask questions that can be answered on the whiteboard and

read (by you) from across the room. This strategy works particularly

well when assessing questions that can be answered in one or two

words, true or false, or for solving mathematical equations.

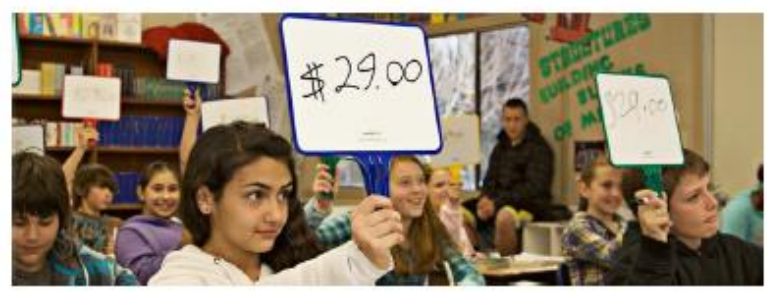

Self-Directed Response

The strategy of self-directed response allows students to, using pictures, numbers, words, or diagrams, demonstrate their understanding of a particular topic.

Formative

Assessment

Formative assessment

allows educators to

monitor student learning

in the moment; whereas

summative assessment

evaluates the students

understanding upon

completion of a unit of

study.

Example: Explain the water cycle using pictures, words, numbers, or a diagram. Explain it in such a way someone who had never heard of it would be able to understand.

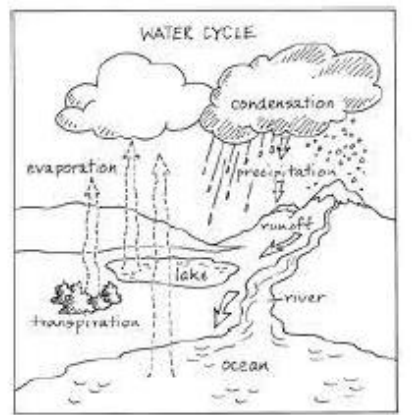




\section{Signal Cards}

Students are given a red, green, and yellow signal cards to keep at their desks. At any given point in a lesson, teachers can ask their students to pull out their signal cards and hold up the color that represents their understanding of the content at that moment in time. Depending on

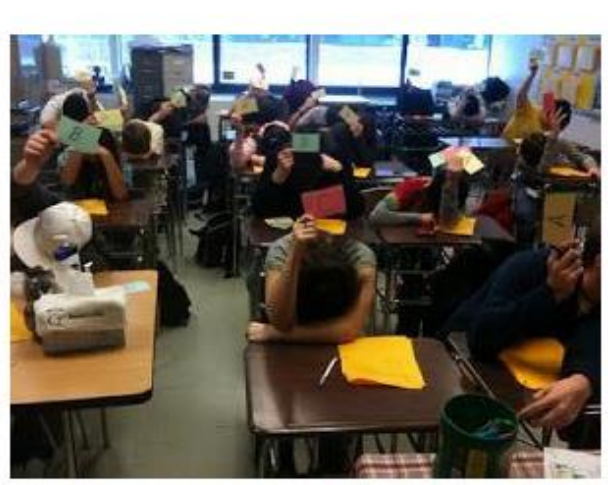

the students' responses, the teacher moves on in their lesson or pauses to reteach.

Students choose which card to display based

on the following criteria:

Red-I don't get it! I need help!

Yellow-1 think I understand, but I have some

questions.

Green-I understand! I can show you.

In addition, the letters A, B, and C can also be added to the signal cards, so you can check for basic understanding using the colors, or you can ask a multiple choice question that can be answered using the letters.

Yes/No Charts

Using a Yes/No chart, students explicitly state what they do and do not understand about a particular topic. Students split their paper into two columns. The left column is labeled "Yes" and the right column is labeled "No."

Example: Use a Yes/No Chart to share what you have learned about Magnetism.

\begin{tabular}{|l|l|}
\hline \multicolumn{1}{|c|}{ Yes } & \multicolumn{1}{|c|}{ No } \\
\hline Magnets produce a magnetic field. & Why don't negative poles don't attract? \\
Magnets are not attracted to glass, plastic or & How can the earth have a magnetic pull? \\
wood. & \\
The opposite poles attract one another. & \\
\hline
\end{tabular}


Cycle of Inquiry

What is a Cycle of Inquiry?

In a cycle of inquiry, teachers are given the opportunity to:

(a) Select and narrow a focus for inquiry into their practice;

(b) Determine what goals they will set and measure;

(c) Create an action plan to work toward accomplishing those goals;

(d) Design a plan for implementing the desired action; and

(e) Collect and analyze data generated by their action

As a participant in the cycle of inquiry, teachers are given the opportunity to see first-hand whether or not their practice is impacting the achievement of their students, particularly their students of color. If teachers are reflecting critically on their own practice and whether or not it

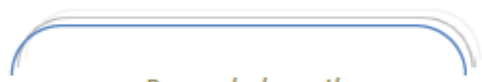

Research shows the traditional model of professional development (one-day workshop or occasional conference) is ineffective in changing the ways in which teachers teach but is the most commonly used type of professional development in the education. professional development activities fall into one of two categories: traditional or reform. Traditional activities, such as the one day workshop or the training model where participants are given a one shot training on how to implement a certain strategy and then set loose to implement the new technique, are least likely to affect change in teachers' practice or beliefs

to begin to look at systems of inequity, which may be their own practice, as the cause for lowered student achievement rather than continue to blame the students themselves (McLaughlin \& Zarrow, 2001).

Why Should We Use a Cycle of Inquiry? Participating in a cycle of inquiry can be beneficial to educators attempting to close the achievement gap for many reasons. First, research shows

affects student learning positively, they are likely 
but are the most commonly participated in by teachers in America (Borko, 2004; Cochrane-Smith \& Lytle, 2001; Darling-Hammond \& McLaughlin, 1995; Falk, 2001; Garet, Porter, Desimone, Birman, \& Yoon, 2001; Guskey, 2002; Little, 1993, 2001; Stokes, 2001). However, teachers participating in reform activities, such as inquiry, report having transformed beliefs about achievement and how their practice influences it (Darling-Hammond \& McLaughlin, 1995; Garet et al., 2001; McLaughlin \& Zarrow, 2001).

\section{Professional Development Characterized as Reformative}

* Professional development that encourages teachers to engage in critical dialogue regarding their practice

* Professional development that encourages teachers to reflect on student learning in a manner which is data driven

* Professional development that encourages teachers to reflect critically on their own practice and its effect on student learning

\section{Inquiry Based Professional Development}

A growing body of literature supports inquiry based professional development as the approach most likely to change the manner in which teachers teach; including how they interact with their students of color. Cochrane-Smith and Lytle (2001) describe inquiry as stance as "the positions teachers and others who work together in inquiry communities take toward knowledge, its relationships to practice, and the purposes of schooling" (pp. 49-50).

Types of

Professional

Development

Traditional Professional Development Activities

- Workshops

- Institutes

- College Courses

- Conferences

Reform Professional Development Activities

- Study Groups

- Mentoring

- Coaching

- Inquiry

- Teacher Collaboratives 
Inquiry as stance allows educators to look critically at their practice (and the results of their practices) in order to determine how they can transform their current practices to meet the needs of all students. This process, I believe, is essential when educators take on the challenge of closing the achievement gap.

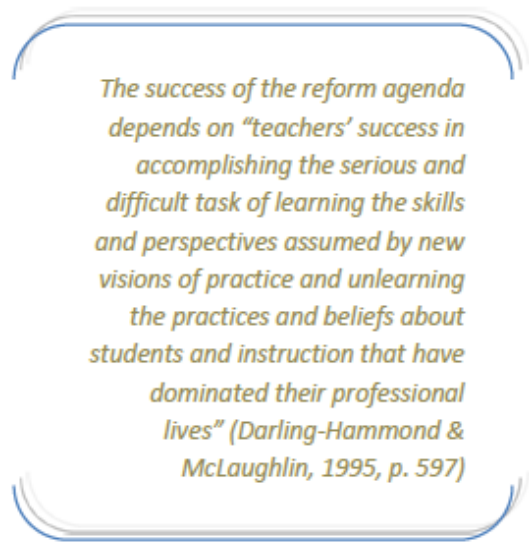

\begin{abstract}
A framework that lends itself well to supporting teachers through the process of taking on a stance of inquiry is the cycle of inquiry (McLaughlin \& Zarrow, 2001). In a cycle of inquiry (See Figure 1), teachers are given the opportunity to: (a) select and narrow a focus for inquiry into their own practice; (b) determine what goals they will set and measure; (c) create an action plan to work toward accomplishing those goals; (d) design a plan for implementing the desired
\end{abstract} action; and (e) collect and analyze data generated by their action (McLaughlin \& Zarrow, 2001). As a participant in the cycle of inquiry, you will be given an opportunity to see first-hand whether or not your practice is impacting the achievement of your students, particularly your students of color.

Cycle of Inquiry Process

The cycle of inquiry process begins after focal students have been selected, and should last anywhere from 2-4 weeks. The following sections will walk you through the steps of implementing a cycle of inquiry in your classroom. 


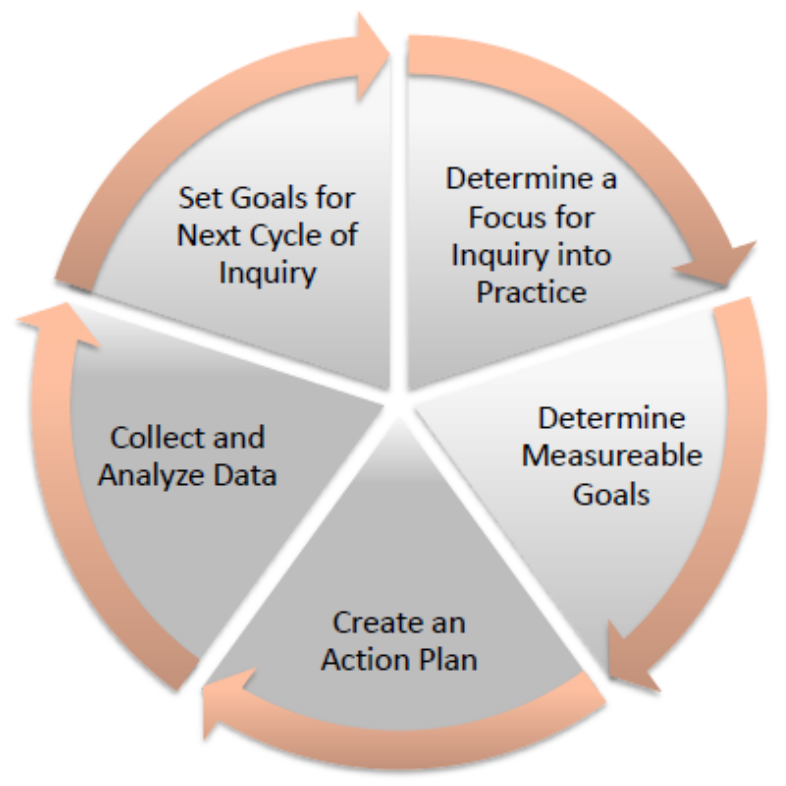

Figure 1. The Cycle of Inquiry Process (McLaughlin \& Zarrow, 2001)

Determining a Focus for Inquiry into Practice

Once you have selected your focal students by analyzing your school's AYP data, your grade level data, or your classroom data, the following questions will help you determine exactly what the focus subject for your first cycle of inquiry should be.

* In what subject area does our focal group need the most support?

* Will support in this area likely lead to increased achievement for our focal students?

* Will an inquiry into this subject area likely lead to improved instruction?

If you are able to answer yes to the last two questions, you have likely found a good starting point for your cycle of inquiry. If you were unable to answer yes to the last two questions, consider choosing a different subject area for your focal group. Once you have settled on a subject area, it is time to narrow your focus by asking the following questions: 
* Within this subject area, on what specific standard should we focus?

* Will focusing on this standard likely lead to improved achievement for our focal students?

Determining Measurable Goals

Measurable goals are, of course, measurable. Meaning you set a clear, precise goal that can be measured quantitatively. For example, focal students will show academic growth of one rubric score or gain of points from pre- to post-test during this cycle of inquiry as measured by the formative and summative assessments. When determining your measureable goals, be sure to be specific and realistic. While all of your focal students may not move into the meets standard performance level, it is possible they will show academic growth set by determining measurable goals.

Creating an Action Plan

Once you have determined your focus and measurable goals, it is time to create an action plan. Consider the following questions when doing so:

* What is the length of the cycle-how long will it take to teach the standard?

* How many lessons will we teach during this cycle?

* How will we use the information we gathered in student interviews and surveys to motivate and engage our focal students?

* How will we teach this standard to ensure our focal students master it?

* How will we measure whether or not our focal students have mastered the standard we have chosen?

Collecting and Analyzing Data

Collecting and analyzing data is essential in the cycle of inquiry process. If you are not using data to determine success, or lack thereof, you are likely to continue on a path of teaching in a 
way that is easy rather than in a manner that is most effective for you focal students. When collecting and analyzing your data, consider the following questions:

* Which focal students showed determined academic growth?

* What data do we have to support this?

* What did we do to support them in making growth?

* Which focal students did not show determined academic growth?

* What data do we have to support this?

* Could we have done something different in our teaching? If so, what could we have done differently?

Determining Next Steps Based on Data

When determining next steps, it is important to analyze where your focal students are as a group. Of course we hope $100 \%$ of focal students will show determined academic growth during a cycle of inquiry, but reality isn't so perfect. This is why determining a measurable goal is important. When you or your team is ready to determine next steps, ask yourselves the following questions:

* Did $80 \%$ or more of our focal students show the determined amount of academic growth?

- If so, what standard will we focus on in our next cycle of inquiry?

- What will we do for those who did not show determined academic growth?

- Will we focus on the same focal students or will they change?

- If we are planning on releasing students from focal student status in our next cycle of inquiry, do we have the data that shows they are solidly in the meets standard, or green zone?

Did less than $80 \%$ of our focal students meet standard?

- If so, will we focus on the same standard in our next cycle of inquiry?

- If not, what data do we have to support our decision to move on?

* How can we modify our instruction to better meet the needs of our focal students? 


\section{Continuing the Work}

You should commend yourself for taking the first step toward ensuring continued equity work. While the journey you are beginning will be long, and at times difficult, the impact you are making will become evident as you see students of color beginning to close the achievement gap in your classroom. While the challenge of ensuring all students receive an opportunity for equitable outcomes in education is significant, it is not impossible. Gone are the days of placing the blame for lowered achievement on students and their families; rather, we are faced with the exciting possibility of reshaping the educational experiences for students who have been historically overlooked.

As you welcome the challenge of Keeping Equity in Mind, celebrate that you are actively working on becoming part of the solution. With each inquiry cycle, you are becoming more equipped to handle the task of educating all of your students. As you progress through multiple cycles, your mindset will change, and you will begin to internalize the process. You will find the way you think about your students of color (and their abilities) will shift; you will recognize that with engaging, targeted instruction, you can make a difference. It is not an impossible task. It is manageable.

You don't have to feel as though the task is too daunting. You can make a difference one day at a time, and you will. You have the power to change how you choose to look at your students. See them as the eager learners they are. Shown them you care for them as learners and individuals. Once you have opened this dialogue with them by getting to know them and engaging them, you will see the possibilities are endless as they move toward academic excellence. 


\section{Determining Focal Students}

Teacher:

Grade:

Focal Group:

Focal Subject Area:

Focal Standard:

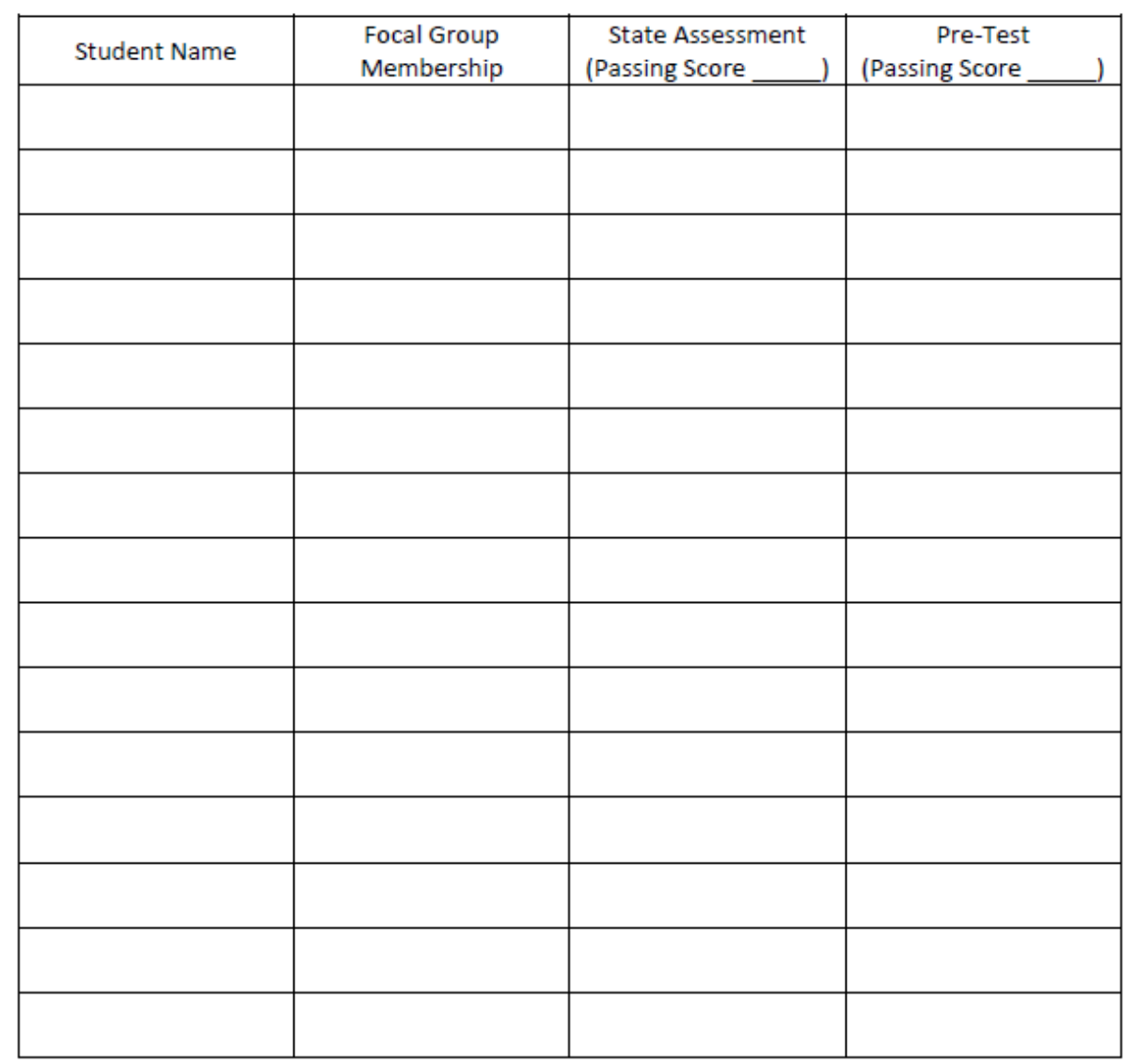




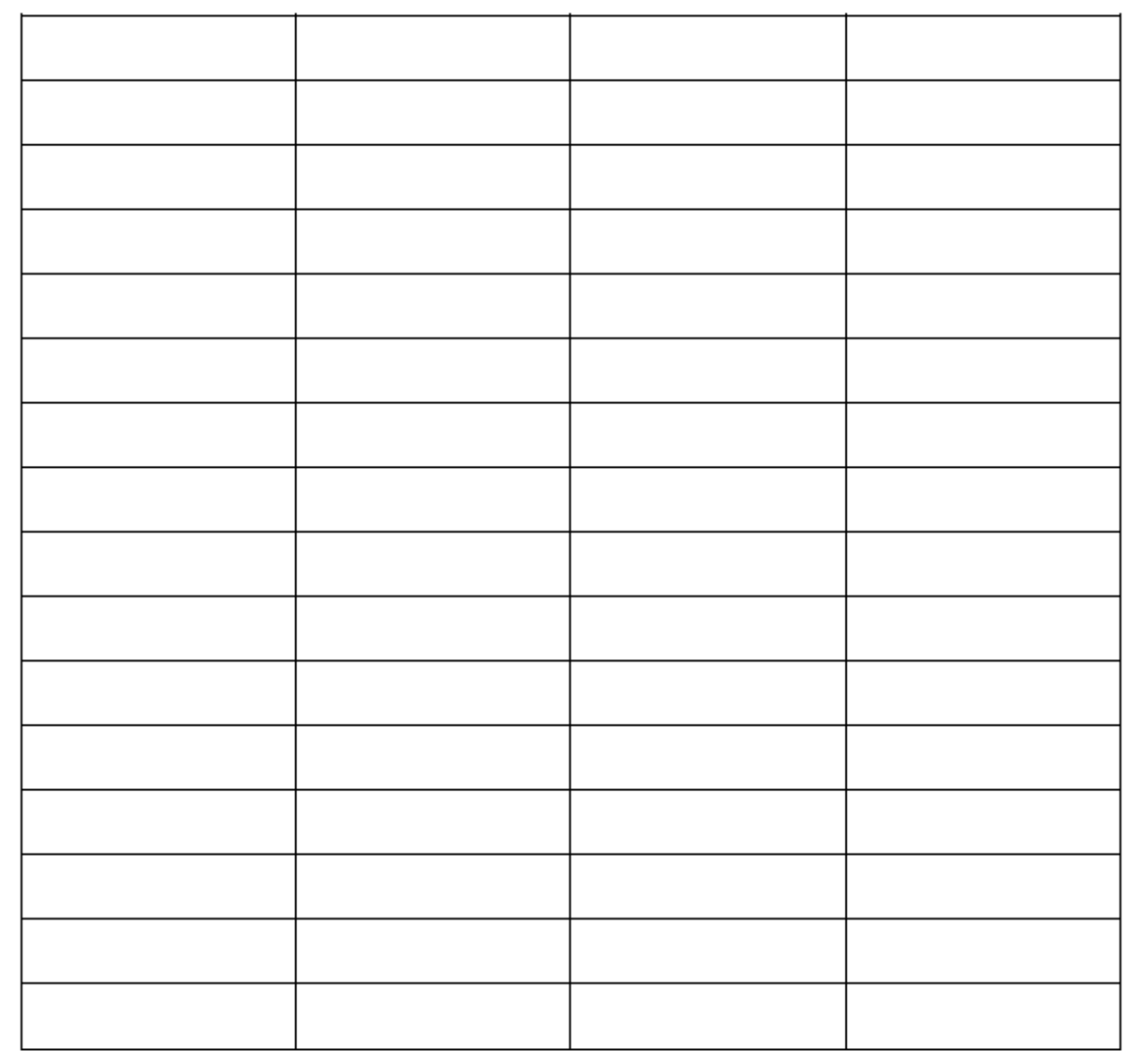

Focal Students:

1.

2.

3.

4.

5. 


\section{Pre-Cycle Planning}

Teacher Name

Focal Student:

Focal Student :

Focal Student :

Date

Focal Student :

Focal Student :

Focal Student:

\section{Relationship Building Strategies}

During this cycle of inquiry, I plan to explicitly use the following relationship building strategies:

1.

2.

3.

Determining Focus for Inquiry

In what subject area does our focal group need the most support? 
What data do we have to support this decision?

Will this support lead to increased student achievement?

Will a cycle of inquiry in this subject area lead to improved instruction?

What specific standard will we focus on?

Will focusing on this standard likely lead to improved achievement for focal students? $\square$ Yes $\square$ No

\section{Determining Measurable Goals}

$80 \%$ of focal students will show academic growth of in the following:

Focal Subject:

Focal Standard:

\section{Action Plan}

Length of Cycle

Approximate Number of Lessons

Teaching Strategies 
Data Collection

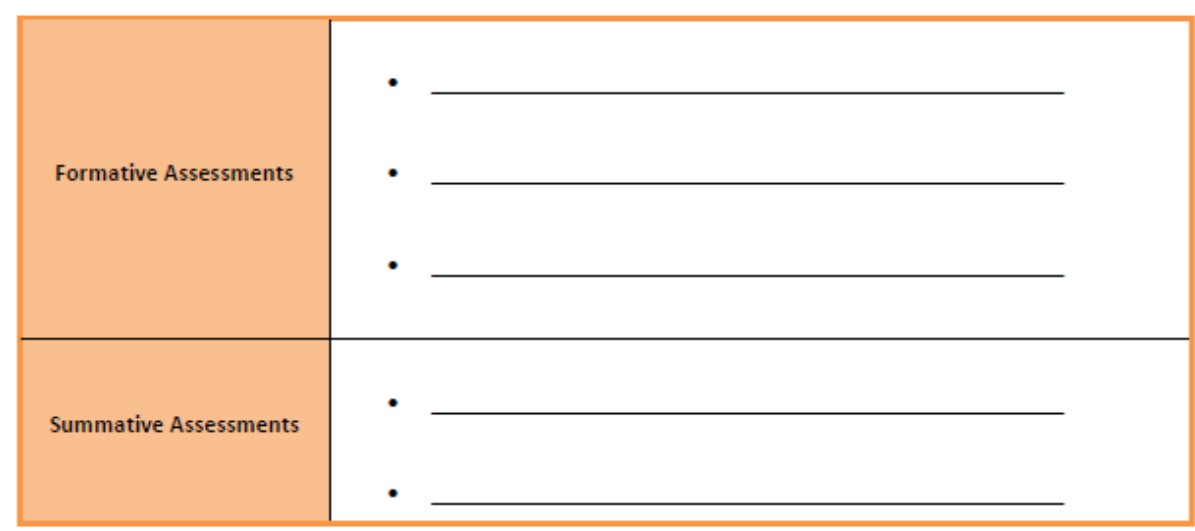

\section{Data Analysis}

Assessment:

Date

Focal Student Data

\begin{tabular}{|l|c|c|}
\hline FS1 & Met & Did Not Meet \\
\hline FS2 & Met & Did Not Meet \\
\hline FS3 & Met & Did Not Meet \\
\hline FS4 & Met & Did Not Meet \\
\hline FS5 & Met & Did Not Meet \\
\hline
\end{tabular}

Plan for students not meeting standard 
Assessment:

Date

Focal Student Data

\begin{tabular}{|l|c|c|}
\hline FS1 & Met & Did Not Meet \\
\hline FS2 & Met & Did Not Meet \\
\hline FS3 & Met & Did Not Meet \\
\hline FS4 & Met & Did Not Meet \\
\hline FS5 & Met & Did Not Meet \\
\hline
\end{tabular}

Plan for students not meeting standard

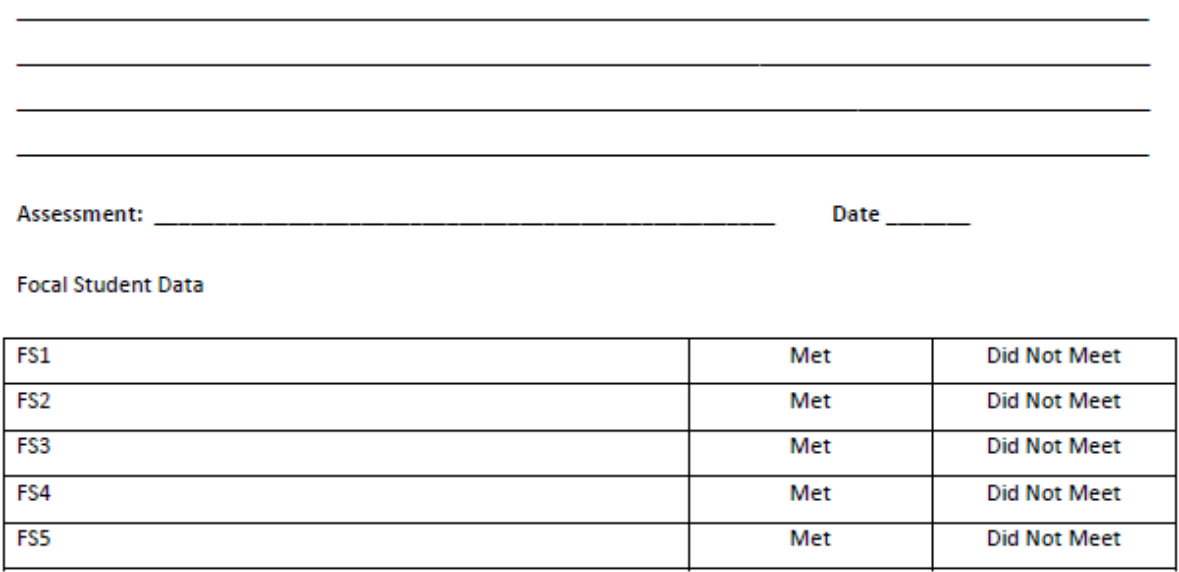

Plan for students not meeting standard 
Assessment:

Date

Focal Student Data

\begin{tabular}{|l|c|c|}
\hline FS1 & Met & Did Not Meet \\
\hline FS2 & Met & Did Not Meet \\
\hline FS3 & Met & Did Not Meet \\
\hline FS4 & Met & Did Not Meet \\
\hline FS5 & Met & Did Not Meet \\
\hline
\end{tabular}

Plan for students not meeting standard

Assessment:

Date

Focal Student Data

\begin{tabular}{|l|c|c|}
\hline FS1 & Met & Did Not Meet \\
\hline FS2 & Met & Did Not Meet \\
\hline FS3 & Met & Did Not Meet \\
\hline FS4 & Met & Did Not Meet \\
\hline FS5 & Met & Did Not Meet \\
\hline
\end{tabular}

Plan for students not meeting standard 
Assessment:

Date

Focal Student Data

\begin{tabular}{|l|c|c|}
\hline FS1 & Met & Did Not Meet \\
\hline FS2 & Met & Did Not Meet \\
\hline FS3 & Met & Did Not Meet \\
\hline FS4 & Met & Did Not Meet \\
\hline FS5 & Met & Did Not Meet \\
\hline
\end{tabular}

Plan for students not meeting standard 
Glossary

Achievement Gap: When students of color are not achieving at the same level as their White and Asian counterparts

Blue Zone: Students in the blue zone are those students who have exceeded standard

Color Blind Lens: When one teaches through a color blind lens, they teach with the notion that all children are created equal, and thus, should be treated exactly the same-therefore, they believe race is not a factor in a student's educational success

Cycle of Inquiry: A framework for teachers to go through the process of determining a focus for inquiry, outlining measurable goals, create an action plan, collect and analyze data, and set goals for their next cycle of inquiry. By participating in a cycle of inquiry, educators are able to see, through data, how their teaching is affecting learning in their classrooms

Discrimination: The act of making a distinction in favor of or against something based on race or religion

Equity: Attempting to even the playing field for members of the minority group with those in the dominant group. Equity is not synonymous with equal. Equal means the same; equity implies that, in order to level the playing field, one must put more energy into closing the gap between the minority and dominant groups-giving equal treatment may not be enough to achieve equity

Fixed Mindset: Students with a fixed mindset believe intelligence is something with which you are born; it is not something you can increase

Focal Students: Students performing below grade level but are within one year of meeting state-wide assessment standards

Formative Assessment: Quick, daily check-ins to see where your students are performing on a particular standard at that particular moment in time. Formative assessment is meant to guide instruction 
Green Zone: Students who are in the Green Zone have met academic standard in that subject area

Growth Mindset: Students with a growth mindset believe intelligence is something you can build upon - that is, it is something you can increase as you are introduced to and engage with new information

Institutionalized Racism: the practices and institutional policies that perpetuate inequitable relationships between people of color and members of the dominant group

Measurable Goal: A goal that can be measured quantitatively

Red Zone: Students in the Red Zone are two or more years behind academic standard as determined by state-wide assessment data

Ripple Effect: The effect that occurs when one action creates several other effects

Summative Assessment: Assessment given at the end of a unit of study-the purpose of summative assessment is to assess what a group of students took away from a unit of study. Most often, summative assessments are not used to modify instruction

Yellow Zone: Students in the Yellow Zone are within one year of meeting standard on statewide assessments 
References

Borko, H. (2004). Professional Development and Teacher Learning: Mapping the Terrain. Educational Researcher, 33(8), 3-15. doi: 10.3102/0013189x033008003

Cochrane-Smith, M., \& Lytle, S. L. (2001). Beyond Certainty: Taking an Inquiry Stance on Practice. In A. Lieberman \& L. Miller (Eds.), Teachers Caught in Action: Professional Development That Matters (pp. 45-58). New York: Teachers College Press.

Darling-Hammond, L. (2007). Third Annual "Brown" Lecture in Education Research--The Flat Earth and Education: How America's Commitment to Equity Will Determine Our Future. Educational Researcher, 36(6), 318334.

Darling-Hammond, L., \& McLaughlin, M. W. (1995). Policies That Support Professional Development in an Era of Reform. Phi Delta Kappan, 76(8), 597-604.

Dweck, C. S. (2006). Mindset : the new psychology of success. New York: Random House.

Falk, B. (2001). Professional Learning Through Assessment. In A. Lieberman \& L. Miller (Eds.), Teachers Caught in the Action: Professional Development That Matters (pp. 118-140). New York: Teachers College Press.

Ferguson, R. (2005). Toward Skilled Parenting \& Transformed Schools Inside a National Movement for Excellence with Equity. Paper presented at the First Educational Equity Symposium of the Campaign For Educational Equity, Teachers College, Columbia University. Conference retrieved from 
Garet, M. S., Porter, A. C., Desimone, L., Birman, B. F., \& Yoon, K. S. (2001). What Makes Professional Development Effective? Results from a National Sample of Teachers. American Educational Research Journal, 38(4), 915945.

Guskey, T. R. (2002). Professional Development and Teacher Change. [Article]. Teachers \& Teaching, 8(3/4), 381-391. doi: $10.1080 / 135406002100000512$

Haycock, K. (2001). Closing the Achievement Gap. [Article]. Educational Leadership, 58(6), 6.

Kidd, J., \& Congdon, L. (2007). About Focal Students. Unpublished. Partners in School Innovation.

Kriete, R., \& Bechtel, L. (2002). The morning meeting book (2nd ed.). Greenfield, MA: Northeast Foundation for Children.

Little, J. W. (1993). Teachers' Professional Development in a Climate of Educational Reform. Educational Evaluation and Policy Analysis, 15(2), 129-151. doi: 10.3102/01623737015002129

Little, J. W. (2001). Professional Development in the Pursuit of Reform. In A. Lieberman \& L. Miller (Eds.), Teachers Caught in the Action (pp. 23-44). New York: Teachers College Press.

McLaughlin, M. W., \& Zarrow, J. (2001). Teachers Engaged in Evidence-Based Reform: Trajectories of Teachers' Inquiry, Analysis, and Action. In A. Lieberman \& L. Miller (Eds.), Teachers Caught in Action: Professional Development That Matters (pp. 79-101). New York: Teachers College Press.

Milner, H. R. I. (2011). Five Easy Ways to Connect with Students. Harvard Educational Review, 27(1). 
Singleton, G. E., \& Linton, C. (2006). Courageous conversations about race : a field guide for achieving equity in schools. Thousand Oaks, Calif.: Corwin Press.

Stokes, L. (2001). Lessons from an Inquiring School: Forms of Inquiry and Conditions for Teacher Learning. In A. Lieberman \& L. Miller (Eds.), Teachers Caught in the Action: Profesional Development That Matters (pp. 141-158). New York: Teachers College Press.

Vanneman, A., Hamilton, L., Anderson, J. B., Rahman, T., \& National Center for Education, S. (2009). Achievement Gaps: How Black and White Students in Public Schools Perform in Mathematics and Reading on the National Assessment of Educational Progress. Statistical Analysis Report. NCES 2009-455: National Center for Education Statistics. 